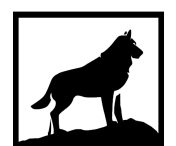

Michigan Technological

1 8 8 5 University
Michigan Technological University Digital Commons @ Michigan Tech

2016

\title{
AN EXPERIMENTAL INVESTIGATION INTO THE EFFECT OF PARTICULATE MATTER ON NOX REDUCTION IN A SCR CATALYST ON A DPF
}

Saksham Gupta

Michigan Technological University, sakshamg@mtu.edu

Copyright 2016 Saksham Gupta

Recommended Citation

Gupta, Saksham, "AN EXPERIMENTAL INVESTIGATION INTO THE EFFECT OF PARTICULATE MATTER ON NOx REDUCTION IN A SCR CATALYST ON A DPF", Open Access Master's Report, Michigan Technological University, 2016.

https://doi.org/10.37099/mtu.dc.etdr/168

Follow this and additional works at: https://digitalcommons.mtu.edu/etdr

Part of the Automotive Engineering Commons, and the Chemical Engineering Commons 


\title{
AN EXPERIMENTAL INVESTIGATION INTO THE EFFECT OF PARTICULATE MATTER ON NO $\mathrm{N}_{\mathrm{x}}$ REDUCTION IN A SCR CATALYST ON A DPF
}

\author{
By \\ Saksham Gupta
}

\begin{abstract}
A REPORT
Submitted in partial fulfillment of the requirements for the degree of

MASTER OF SCIENCE

In Mechanical Engineering
\end{abstract}

MICHIGAN TECHNOLOGICAL UNIVERSITY

2016

(C) 2016 Saksham Gupta 
This report has been approved in partial fulfillment of the requirements for the Degree of MASTER OF SCIENCE in Mechanical Engineering

Department of Mechanical Engineering- Engineering Mechanics

Report Co-Advisor: Dr. Jeffrey Naber

Report Co-Advisor: Dr. John Johnson

Committee Member: Dr. David Shonnard

Department Chair: Dr. William Predebon 


\section{Table of Contents}

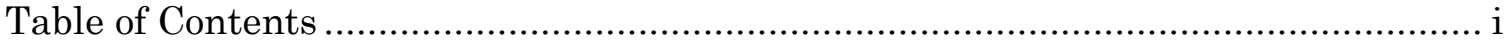

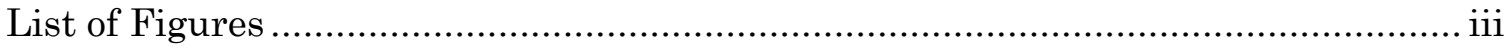

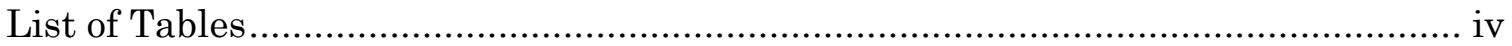

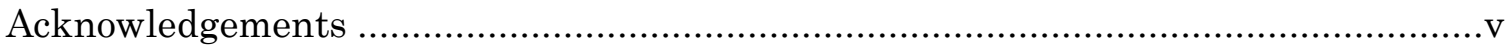

Common Terms and Abbreviations .................................................................... vi

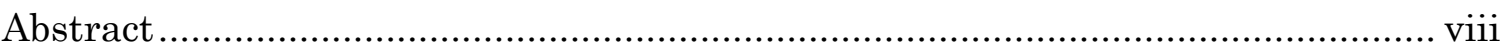

Chapter 1. Introduction ............................................................................ 1

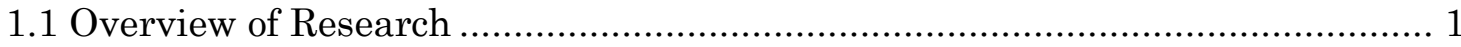

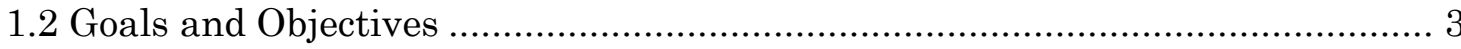

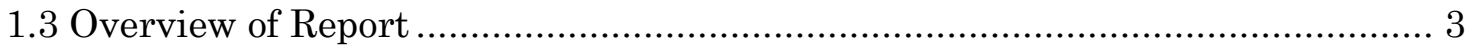

Chapter 2. Experimental Setup, Instrumentation, and Test Procedures.............. 4

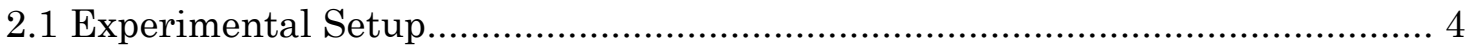

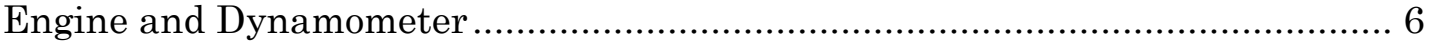

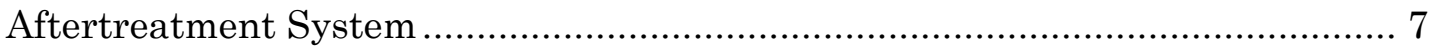

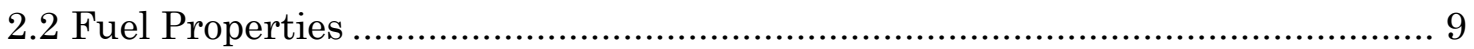

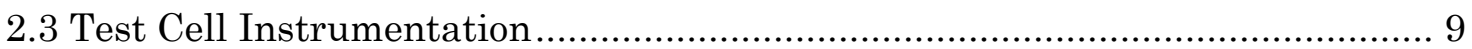

Air and Fuel Flow Measurement..................................................................... 9

Pressure Measurement................................................................................ 10

Temperature Measurement ............................................................... 10

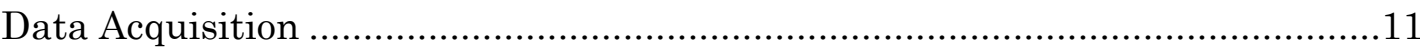

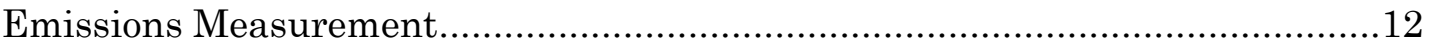

Particulate Matter Sampling and Measurement .......................................... 12

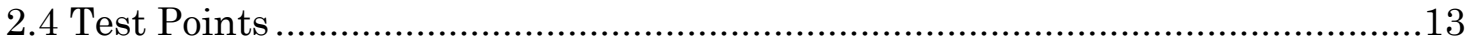

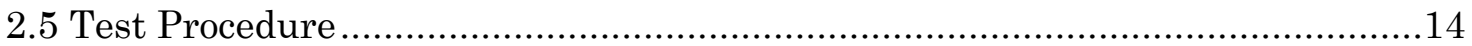

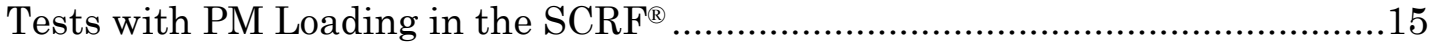

Tests without PM Loading in the $\mathrm{SCRF}^{\circledR}$.....................................................19

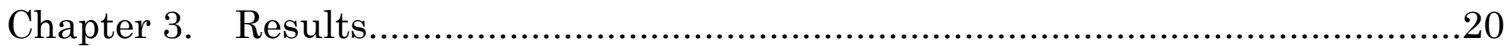

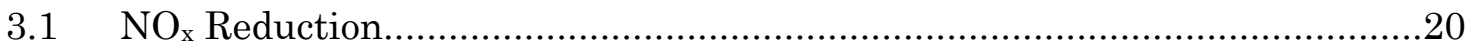

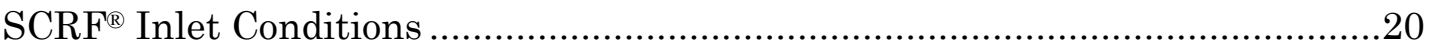

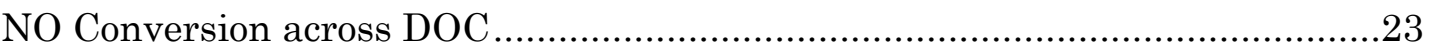

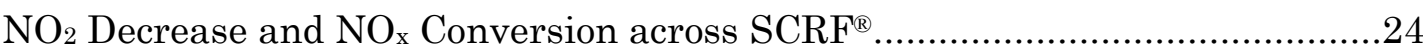

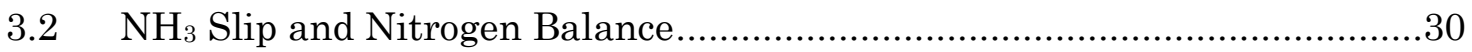




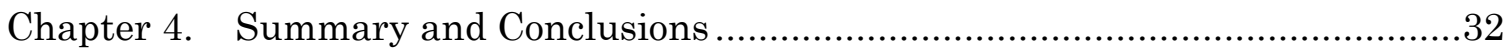

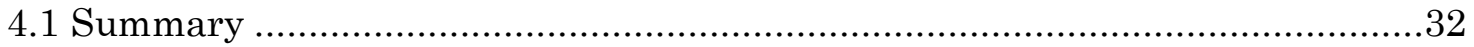

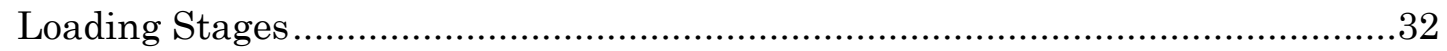

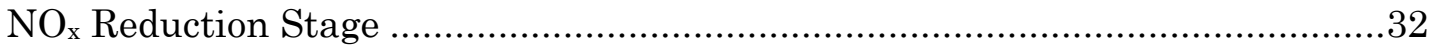

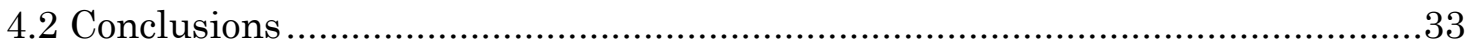

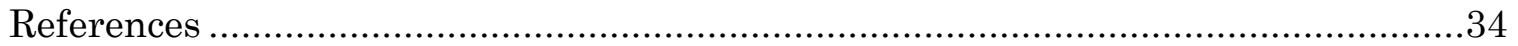

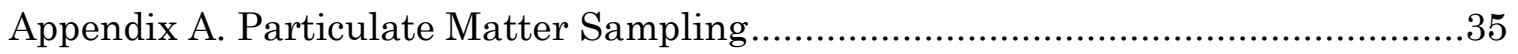

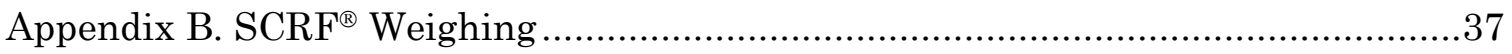

Appendix C. Engine, Exhaust Conditions and PM Mass Balance for Each Stage.....38

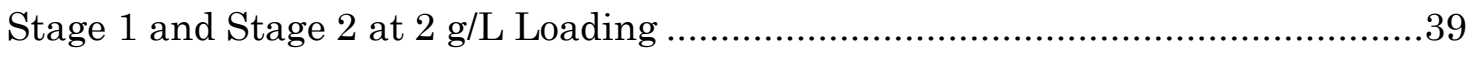

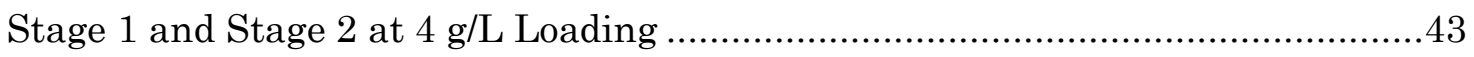

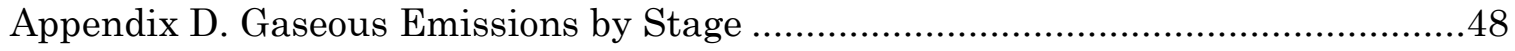

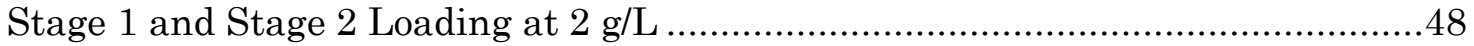

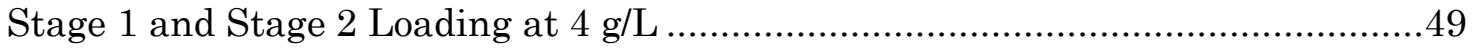

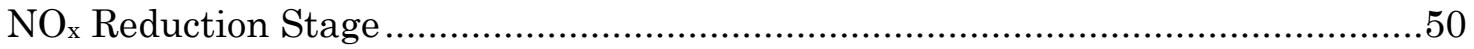

Appendix E. SCRF ${ }^{\circledR}$ Pressure Drops ….............................................................52

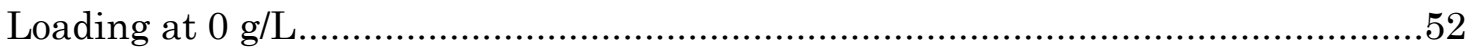

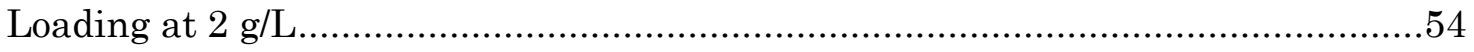

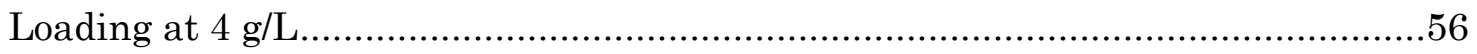

Appendix F. SCRF ${ }^{\circledR}$ Temperature Distributions..................................................59

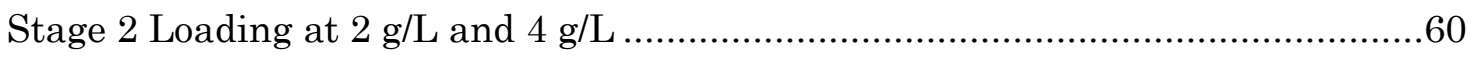

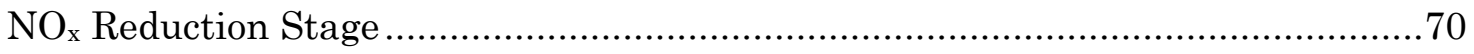

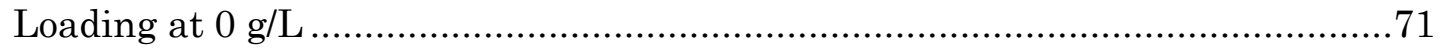

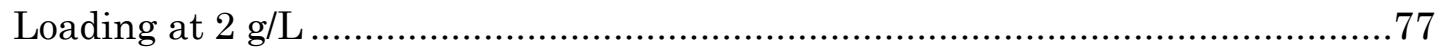

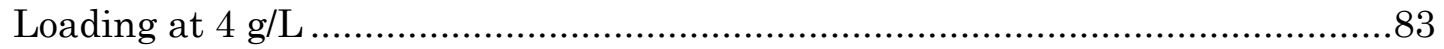

Appendix G. Permission to Use Copyrighted Material .........................................89 


\section{List of Figures}

Figure 1.1 Overview of aftertreatment system [2] f....................................... 2

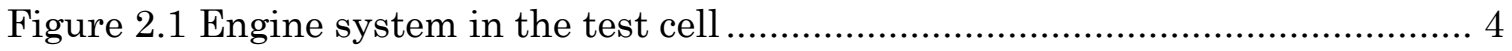

Figure 2.2 Experimental setup showing the location of sampling lines, pressure port lines, and the dynamometer in the test cell ....................................................... 5

Figure 2.3 Aftertreatment system with sensors and instrumentation..................... 6

Figure 2.4 $\mathrm{SCRF}^{\circledR}$ thermocouple arrangement - Dimensions are in mm.................11

Figure 2.5 Schematic representation of the process of testing with PM loading in the $\mathrm{SCRF}^{\circledR}$

Figure 2.6 Pressure drop curve for Stage 1, Stage 2 and repeat loading in between

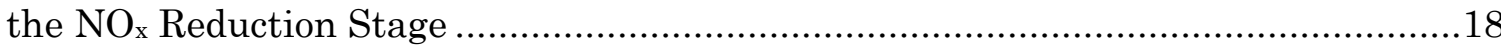

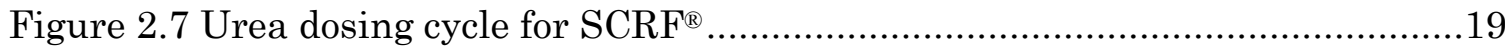

Figure 2.8 Schematic representation of the process of testing without PM loading in the $\mathrm{SCRF}^{\circledR}$

Figure 3.1 Inlet $\mathrm{SCRF}^{\circledR} \mathrm{NO}_{2} / \mathrm{NO}_{\mathrm{x}}$ ratio at different $\mathrm{SCRF}^{\circledR}$ inlet temperatures (test points)

Figure 3.2 Change in $\mathrm{NO}_{2} / \mathrm{NO}_{\mathrm{x}}$ ratio at inlet and outlet of the $\mathrm{SCRF}^{\circledR}$ with different $\mathrm{SCRF}^{\circledR}$ inlet temperatures for 0,2 , and $4 \mathrm{~g} / \mathrm{L}$ loading ANR - 0

Figure 3.3 Variation of $\mathrm{NO}_{\mathrm{x}}$ conversion efficiency (\%) with $\mathrm{ANR}-0.8$ for $\mathrm{NO}_{\mathrm{x}}$ reduction test points and $\mathrm{SCRF}^{\circledR}$ inlet temperatures

Figure 3.4 Variation of $\mathrm{NO}_{\mathrm{x}}$ conversion efficiency (\%) with $\mathrm{ANR}-1$ for $\mathrm{NO}_{\mathrm{x}}$ reduction test points and SCRF® inlet temperatures

Figure 3.5 Variation of $\mathrm{NO}_{\mathrm{x}}$ conversion efficiency (\%) with $\mathrm{ANR}-1.2$ for $\mathrm{NO}_{\mathrm{x}}$

reduction test point

Figure $3.6 \mathrm{NH}_{3}$ slip from $\mathrm{SCRF}^{\circledR}$ for $\mathrm{NO}_{\mathrm{x}}$ reduction test points at $\mathrm{ANR}-0.8 \ldots \ldots \ldots . . .31$

Figure $3.7 \mathrm{NH}_{3}$ slip from $\mathrm{SCRF}^{\circledR}$ for $\mathrm{NO}_{x}$ reduction test points at $\mathrm{ANR}-1 \ldots \ldots \ldots \ldots . . .31$

Figure $3.8 \mathrm{NH}_{3}$ slip from $\mathrm{SCRF}^{\circledR}$ for $\mathrm{NOx}$ reduction test points at $\mathrm{ANR}-1.2$ Repeat

(Rpt.). 


\section{List of Tables}

Table 2.1 Specifications of the Cummins ISB 2013 engine.................................... 7

Table 2.2 Eddy current dynamometer specifications .......................................... 7

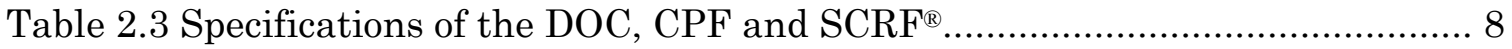

Table 2.4 Specification of fuel used for testing [2] .............................................. 9

Table 2.5 Specifications of pressure transducer............................................... 10

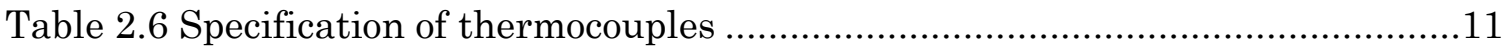

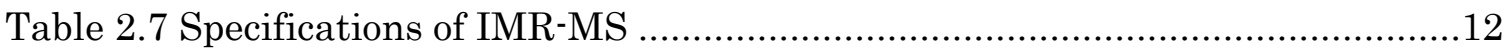

Table 2.8 Specifications of Mettler Toledo UMT2 microbalance [2] .........................13

Table 2.9 Specifications of weighing apparatus [2]............................................13

Table 2.10 Test matrix of baseline SCR tests for $\mathrm{NO}_{\mathrm{x}}$ reduction experiments..........14

Table 3.1 Engine and $\mathrm{SCRF}^{\circledR}$ inlet conditions at different test points for $\mathrm{NO}_{\mathrm{x}}$

reduction test

Table 3.2 NO and $\mathrm{NO}_{2}$ species concentration at the inlet and outlet DOC for different

test points.

Table 3.3 DOC inlet temperature, space velocity and NO conversion efficiency for different test points....

Table 3.4 Species concentration at upstream and downstream $\mathrm{SCRF}^{\circledR}$ for $\mathrm{NO}_{\mathrm{x}}$ reduction test points at ANR-0.8

Table 3.5 Species conversion efficiency across $\mathrm{SCRF}^{\circledR}$ for $\mathrm{NO}_{\mathrm{x}}$ reduction test points at ANR-0.8

Table 3.6 Species concentration at upstream and downstream $\mathrm{SCRF}^{\circledR}$ for $\mathrm{NO}_{\mathrm{x}}$ reduction test points at ANR-1

Table 3.7 Species conversion efficiency across $\mathrm{SCRF}^{\circledR}$ for $\mathrm{NO}_{\mathrm{x}}$ reduction test points at ANR-1

Table 3.8 Species concentration at upstream and downstream $\mathrm{SCRF}^{\circledR}$ for $\mathrm{NO}_{\mathrm{x}}$ reduction test points at ANR-1.2

Table 3.9 Species conversion efficiency across $\mathrm{SCRF}^{\circledR}$ for $\mathrm{NO}_{\mathrm{x}}$ reduction test points at

ANR-1.2. 


\section{Acknowledgements}

I wish to express my sincere gratitude to several people who were associated with this research study directly or indirectly, from my personal and professional life, without whom I would have never been able to finish my report. I am thankful to my committee members, student research group, friends, and my parents for their continued guidance and support in my research.

I would like to thank my advisors Dr. John Johnson and Dr. Jeffrey Naber for providing me this excellent opportunity to work in this Consortium project and providing me continued guidance and support during the course of my research. I thank the MTU Consortium for providing me support during the course of my research. I am thankful to Dr. David Shonnard for being part of my defense committee. Dr. John Johnson provided immense guidance on analyzing the data critically and providing close feedback on report writing. I would like to thank Dr. Jeffrey Naber, who helped me better understand the instrumentation and experimentation in the test cell and provided me the guidance on troubleshooting instrumental failures in the test cell. Krishna Chilumukuru, currently at Cummins, was helpful in providing information about the components, instruments and procedures used for testing.

My thanks are extended to my research group colleagues at Michigan Tech, Vaibhav Kadam for helping me understand the test cell and test procedure, Erik Gustafson and Sagar Sharma for their assistance during the testing. Thanks are also extended to Steve Lehmann and Christopher Pinnow from Michigan Tech for guiding me in setting up and troubleshooting electrical wires and connection in the test cell. 


\section{Common Terms and Abbreviations}

This section lists the terms/abbreviations used commonly throughout this report

\section{Abbreviations}

LFE:

ULSD:

DOC:

DPF:

CPF:

SCR:

$\mathrm{SCRF}^{\circledR}:$

MTU:

MST:

DGM:

PM:

$\mathrm{H} / \mathrm{C}$ :

$\mathrm{NO}, \mathrm{NO}_{2}, \mathrm{NO}_{\mathrm{x}}$ :

$\mathrm{CO}, \mathrm{CO}_{2}, \mathrm{O}_{2}$ :

$\mathrm{NH}_{3}$ :

$\mathrm{NH}_{3}$ Slip:

$\mathrm{NO}_{2} / \mathrm{NO}_{\mathbf{x}}$ :

S1:

S2:

Std.:

Act.:

Conc.:

ANR:

Vel.:

MW:
Laminar Flow Element

Ultra Low Sulphur Diesel

Diesel Oxidation Catalyst

Diesel Particulate Filter

Catalyzed Particulate Filter

Selective Catalytic Reduction

Selective Catalytic Reduction Filter (produced by JohnsonMatthey)

Michigan Technological University

Manual Sampling Train

Dry Gas Meter

Particulate Matter

Hydrogen to Carbon ratio

Nitric Oxide, Nitrogen Dioxide, $\left(\mathrm{NO}+\mathrm{NO}_{2}\right)$

Carbon Monoxide, Carbon Dioxide, Oxygen

Ammonia

Ammonia coming out of the system

Ratio of $\mathrm{NO}_{2}$ concentration to $\mathrm{NO}_{\mathrm{x}}$ concentration

Stage 1

Stage 2

Standard

Actual

Concentration

Ammonia to $\mathrm{NO}_{\mathrm{x}}$ ratio

Velocity

Molecular Weight 


\begin{tabular}{|c|c|}
\hline UDOC: & Upstream DOC \\
\hline DDOC: & Downstream DOC \\
\hline USCRF: & Upstream SCRF $^{\circledR}$ \\
\hline DSCRF: & Downstream SCRF ${ }^{\circledR}$ \\
\hline $\mathrm{SCRF}^{\circledR}-0$ : & $\mathrm{SCRF}^{\circledR}$ loaded to $0 \mathrm{~g} / \mathrm{L} \mathrm{PM}$ \\
\hline $\mathrm{SCRF}^{\circledR}-2:$ & $\mathrm{SCRF}^{\circledR}$ loaded to $2 \mathrm{~g} / \mathrm{L} \mathrm{PM}$ \\
\hline $\mathrm{SCRF}^{\circledR}-4:$ & $\mathrm{SCRF}^{\circledR}$ loaded to $4 \mathrm{~g} / \mathrm{L} \mathrm{PM}$ \\
\hline MFR: & Mass Flow Rate \\
\hline $\mathrm{NO}_{2} / \mathrm{PM}:$ & Ratio of $\mathrm{NO}_{2}(\mathrm{mg})$ to $\mathrm{PM}(\mathrm{mg})$ \\
\hline Conv: & Conversion \\
\hline hr.: & Hour \\
\hline $\mathrm{P}:$ & Pressure \\
\hline Temp.: & Temperature \\
\hline $\mathrm{V}:$ & Volume \\
\hline $\mathrm{mg} / \mathrm{scm}:$ & milligram /standard cubic met \\
\hline
\end{tabular}

\section{Symbols}

$\begin{array}{ll}\text { ®: } & \text { Registered Trademark } \\ \rho: & \text { Density } \\ \%: & \text { Percent } \\ \circ: & \text { Degrees } \\ \text { W/: } & \text { With } \\ \text { W/O: } & \text { Without } \\ \pm: & \text { Plus or minus } \\ \Delta X: & \text { Overall change in quantity ' } \mathrm{X}\end{array}$




\section{Abstract}

The study of $\mathrm{NO}_{\mathrm{x}}$ reduction across the $\mathrm{SCRF}^{\circledR}$ is presented in this report to understand the inlet and outlet $\mathrm{NO}, \mathrm{NO}_{2}, \mathrm{NH}_{3}$ species from the $\mathrm{SCRF}^{\circledR}$. The $\mathrm{SCRF}^{\circledR}$ is a prototype SCR catalyst on a Diesel Particulate Filter (DPF) that reduces NOx and PM at the downstream location. The $\mathrm{SCRF}^{\circledR}$ reduces the packaging volume of the aftertreatment components in order to reduce the cost, volume and weight of the aftertreatment system. A total of 12 experiments were performed on a Cummins ISB $2013280 \mathrm{hp}$ engine and the aftertreatment system. The tests were performed to investigate the $\mathrm{NO}_{\mathrm{x}}$ reduction performance of the $\mathrm{SCRF}^{\circledR}$ under various Particulate Matter loading.

The loading phase has been divided into two stages: Stage 1 and Stage 2. Stage 1 begins after all the PM has been removed from the $\mathrm{SCRF}^{\circledR}$, which is then followed by Stage 2 loading. The engine is run at $2400 \mathrm{rpm}$ and $200 \mathrm{Nm}$ load with different fuel rail pressures for a duration to achieve PM loadings of 0,2 , and $4 \mathrm{~g} / \mathrm{L}$ (grams of PM per volume of the $\left.\mathrm{SCRF}^{\circledR}\right)$ in the $\mathrm{SCRF}^{\circledR}$.

For the testing of the $\mathrm{SCRF}^{\circledR}$ without PM loading, a Catalyzed Particulate Filter (CPF) was placed before the $\mathrm{SCRF}^{\circledR}$. After the loading phase, $\mathrm{NO}_{\mathrm{x}}$ reduction stage was run at different engine conditions. The engine speed and load conditions were selected for the $\mathrm{NO}_{\mathrm{x}}$ reduction stage, named as test points $1,3,6$, and 8 , in order to attain a wide range in space velocities, inlet temperatures and $\mathrm{NO}_{2} / \mathrm{NO}_{\mathrm{x}}$ ratios in the $\mathrm{SCRF}^{\circledR}$, which are the major parameters determining $\mathrm{NO}_{\mathrm{x}}$ reduction efficiency in the $\mathrm{SCRF}^{\circledR}$. The exhaust temperature varied from 206 to $443{ }^{\circ} \mathrm{C}$, inlet $\mathrm{NO}_{2} / \mathrm{NO}_{\mathrm{x}}$ ratio varied from 0.22 to 0.46 , and space velocity varied from 13.5 to $48.2 \mathrm{k} / \mathrm{hr}$. Urea was dosed in the decomposition tube before the $\mathrm{SCRF}^{\circledR}$ to determine the $\mathrm{NO}_{\mathrm{x}}$ conversion efficiency at different ammonia to $\mathrm{NO}_{\mathrm{x}}$ ratio (ANR) values. The $\mathrm{ANR}$ values considered for the $\mathrm{NO}_{\mathrm{x}}$ reduction and $\mathrm{NH}_{3}$ slip were $0,0.8,1,1.2$, and 1.2 repeat. The ANR of 1.2 was repeated in the urea dosing cycle.

It was found that the $\mathrm{NO}_{\mathrm{x}}$ conversion efficiency across the $\mathrm{SCRF}^{\circledR}$ is maximum for test points 3 and 6 i.e. for the temperature range of $300-350{ }^{\circ} \mathrm{C}$. The $\mathrm{NO}_{2} / \mathrm{NO}_{\mathrm{x}}$ ratio at those points was around $0.42-0.46$. It is observed that the loading in the $\mathrm{SCRF}^{\circledR}$ does not affect the $\mathrm{NO}_{\mathrm{x}}$ conversion efficiency at low $\left(205^{\circ} \mathrm{C}\right)$ and high $\left(440{ }^{\circ} \mathrm{C}\right)$ temperature points but affects in between. The $\mathrm{NO}_{\mathrm{x}}$ conversion efficiency improved with $\mathrm{PM}$ 
loading until $300^{\circ} \mathrm{C} \mathrm{SCRF}{ }^{\circledR}$ inlet temperature and decreased (with PM loading) after $350{ }^{\circ} \mathrm{C}$. There is noticeable ammonia oxidation at temperatures above $400{ }^{\circ} \mathrm{C}$ in the $\mathrm{SCRF}^{\circledR}$ that affects $\mathrm{NO}_{\mathrm{x}}$ conversion efficiency [1]. At higher temperature of about 440 ${ }^{\circ} \mathrm{C}, \mathrm{NH}_{3}$ slip is observed varying with $\mathrm{PM}$ loading in the $\mathrm{SCRF}^{\circledR}$. With $\mathrm{PM}$ loading, $\mathrm{NO}_{2}$ assisted oxidation increases the concentration of $\mathrm{NO}$ [2] and affects the $\mathrm{NO}_{\mathrm{x}}$ conversion efficiency.

It is concluded from the results that the $\mathrm{NO}_{2}$ concentration across the $\mathrm{SCRF}^{\circledR}$ decreased with $\mathrm{PM}$ loading and $\mathrm{SCRF}^{\circledR}$ temperature due to $\mathrm{NO}_{2}$ assisted $\mathrm{PM}$ oxidation. The impact of PM loading on $\mathrm{NO}_{\mathrm{x}}$ reduction in the SCRF® was insignificant below 300 ${ }^{\circ} \mathrm{C}$. $\mathrm{NO}_{\mathrm{x}}$ conversion decreased by $3-5 \%$ above $350{ }^{\circ} \mathrm{C}$ with increase in PM loading from 0 to 2 and $4 \mathrm{~g} / \mathrm{L}$, due to consumption of $\mathrm{NO}_{2}$ via passive oxidation of $\mathrm{PM}$. The $\mathrm{NO}_{\mathrm{x}}$ concentration is not completely converted across the $\mathrm{SCRF}^{\circledR}$ at temperatures above $350{ }^{\circ} \mathrm{C}$ even if dosed with an ANR value of 1.2 . 


\section{Chapter 1. Introduction}

Emissions from diesel engines have always been an area of research due to their impact on the environment. To mitigate pollution, control of engine emissions is a statutory requirement, standards of which are set by US EPA. One of the techniques to control $\mathrm{NO}_{\mathrm{x}}$ emissions practically and economically is by having a Selective Catalytic Reduction (SCR) catalyst on a Diesel Particulate Filter (DPF), called a $\mathrm{SCRF}^{\circledR}$. The $\mathrm{SCRF}^{\circledR}$ is one of the latest technologies, which is a combination of SCR and DPF that results in both Particulate Matter (PM) Oxidation and $\mathrm{NO}_{\mathrm{x}}$ reduction. This technology has proved to efficiently reduce $\mathrm{NO}_{\mathrm{x}}$ emissions by $95 \%$ and has helped in preventing ammonia slip at the downstream location [3]. A flow through SCR can be added in the engine exhaust to diminish $\mathrm{NO}_{\mathrm{x}}$ emissions and to reduce fuel consumption while engines are run at higher load.

This part of the research was carried out on a Cummins 2013 ISB diesel engine that was fitted with an aftetreatment system comprising of a Diesel Oxidation Catalyst (DOC), Catalyzed Particulate Filter (CPF), and SCRF ${ }^{\circledR}$ (SCR catalyst on a DPF). Experiments were carried out to study the $\mathrm{NO}_{\mathrm{x}}$ conversion efficiency of the $\mathrm{SCRF}^{\circledR}$ and the experimental data will also be used for the calibration of the $\mathrm{SCRF}^{\circledR}$ model.

\subsection{Overview of Research}

The Diesel Engine Aftertreatment Consortium project aims to conduct experimental and modeling research on advanced aftertreatment systems. The study focuses on PM oxidation and $\mathrm{NO}_{\mathrm{x}}$ reduction characteristics of $\mathrm{CPF}, \mathrm{SCR}$, and $\mathrm{SCRF}^{\circledR}$. $\mathrm{SCRF}^{\circledR}$ is a substrate developed by Johnson Matthey and is being used in the Consortium project for testing. The objective of this research is to study the reactions for the $\mathrm{NO}_{\mathrm{x}}$ reduction in the $\mathrm{SCRF}^{\circledR}$ with and without PM loading. The observations and results of the experimental tests of the $\mathrm{SCRF}^{\circledR}$ with and without PM were analyzed, compared, and the experimental data will be used to calibrate the system model.

The aftertreatment system configuration is shown in Figure 1.1. The first component is the DOC whose function is to oxidize $\mathrm{CO}, \mathrm{NO}$, and the hydrocarbons present in the exhaust stream. The Figure 1.1 describes two layouts: 
1. Without PM loading - As shown in figure, the CPF is placed downstream the DOC such that the CPF filters all the PM coming in the exhaust.

2. With PM loading - Spacer, an empty block, is placed downstream DOC (in place of the CPF as done in Figure 1.1) that allows all PM to pass through it.

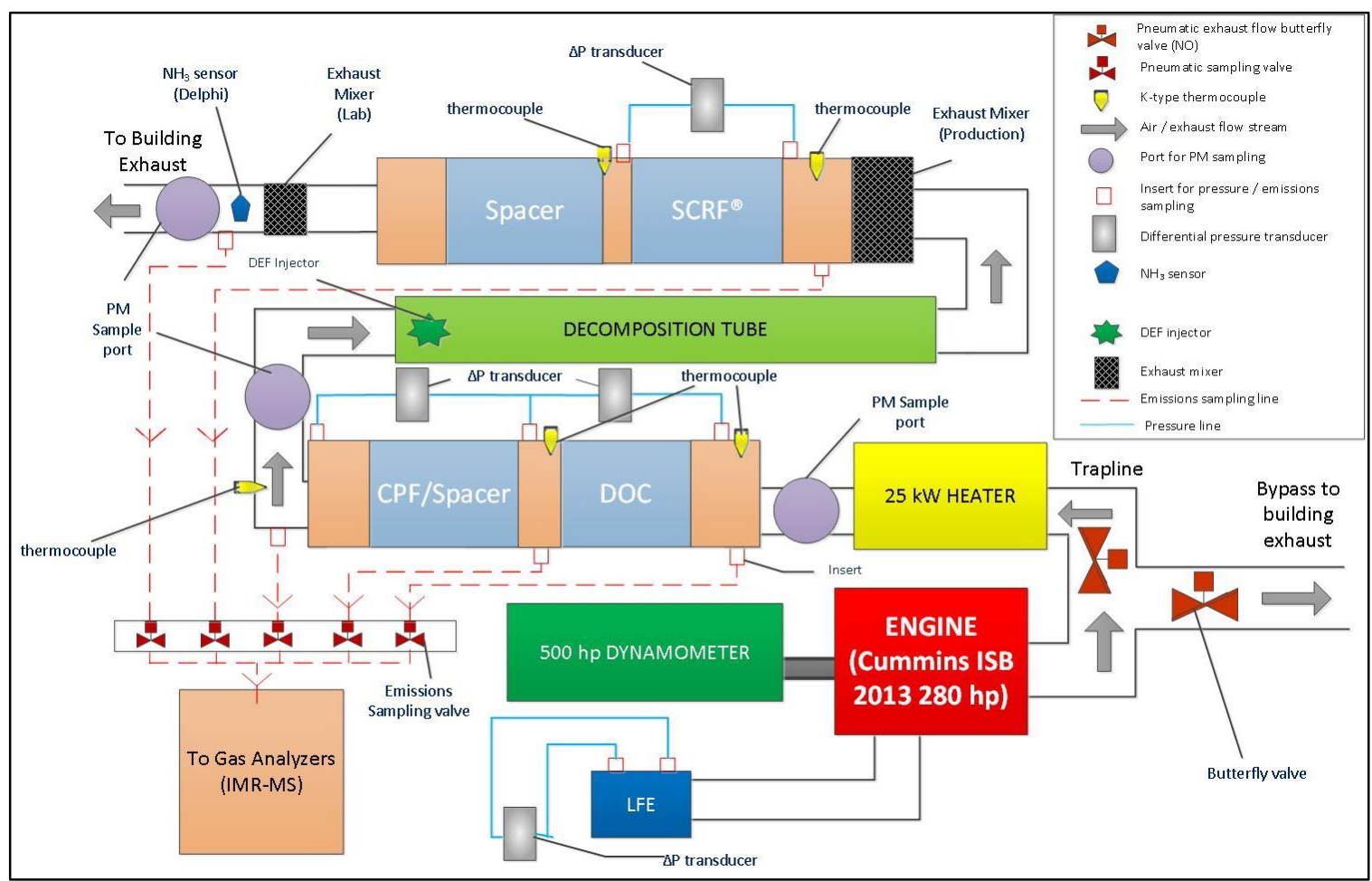

Figure 1.1 Overview of aftertreatment system [2] 


\subsection{Goals and Objectives}

The goal of the research project is to understand the performance of the DPF with an SCR catalyst coated on the substrate by experimental studies.

To achieve efforts towards this goal, experimental studies were conducted on the $\mathrm{SCRF}^{\circledR}$ to determine the $\mathrm{NO}_{\mathrm{x}}$ reduction efficiency of the $\mathrm{SCRF}^{\circledR}$ with and without $\mathrm{PM}$ loading in order to understand the effect of PM on the kinetics of the SCR catalyst. Various parameters such as $\mathrm{NO}, \mathrm{NO}_{2}$, and $\mathrm{NH}_{3}$ (at the upstream and downstream locations of the $\mathrm{SCRF}^{\circledR}$ ), pressure drop (across the $\mathrm{SCRF}^{\circledR}$ ), and temperature distribution (across the $\mathrm{SCRF}^{\circledR}$ ) were studied to determine the $\mathrm{NO}_{\mathrm{x}}$ reduction efficiency of the $\mathrm{SCRF}^{\circledR}$ with and without PM loading.

The $\mathrm{SCRF}^{\circledR}$ experimental data collected will be used to develop and calibrate the MTU SCR-F model.

The following are the specific objectives:

1. To develop procedures for testing the $\mathrm{SCRF}^{\circledR}$ under engine load conditions and collect the data to support the $\mathrm{SCRF}^{\circledR}$ model calibration effort.

2. To use the Cummins 2013 ISB diesel engine at selected engine conditions to attain desired exhaust parameters of temperature, space velocities, $\mathrm{NO}_{2} / \mathrm{NO}_{\mathrm{x}}$ ratios and $\mathrm{NO}_{2} / \mathrm{PM}$ ratios and study if $\mathrm{PM}$ has an effect on the $\mathrm{NO}_{x}$ reduction trend and the SCR reactions.

3. To compare the data collected for the $\mathrm{SCRF}^{\circledR}$ tests with and without PM loading.

\subsection{Overview of Report}

The report discusses the experimental study conducted in the Heavy Duty Diesel Lab at MTU to understand the $\mathrm{NO}_{\mathrm{x}}$ reduction and $\mathrm{NH}_{3}$ slip in the $\mathrm{SCRF}^{\circledR}$. Chapter 2 discusses the experimental setup, and the instrumentation used to collect the data. Chapter 3 contains the results of the research for the tests on the SCRF ${ }^{\circledR}$. Chapter 4 summarizes and determines the findings of the research and discusses future work. 


\section{Chapter 2. Experimental Setup, Instrumentation, and Test Procedures}

This chapter discusses the experimental setup, instrumentation, and procedures used for conducting the experiments. The Heavy Duty Diesel Lab at Michigan Technological University contains the engine, dynamometer, fuel flow meter, data acquisition system, aftertreatment system, Pierburg emission bench, mass spectrometer and other measuring instruments.

\subsection{Experimental Setup}

This section discusses the engine and the aftertreatment system used for the testing. Figure 2.1 and 2.2 show the layout of the engine and the aftertreatment system components along with various sensors, ports, and other instrumentation in the test cell.

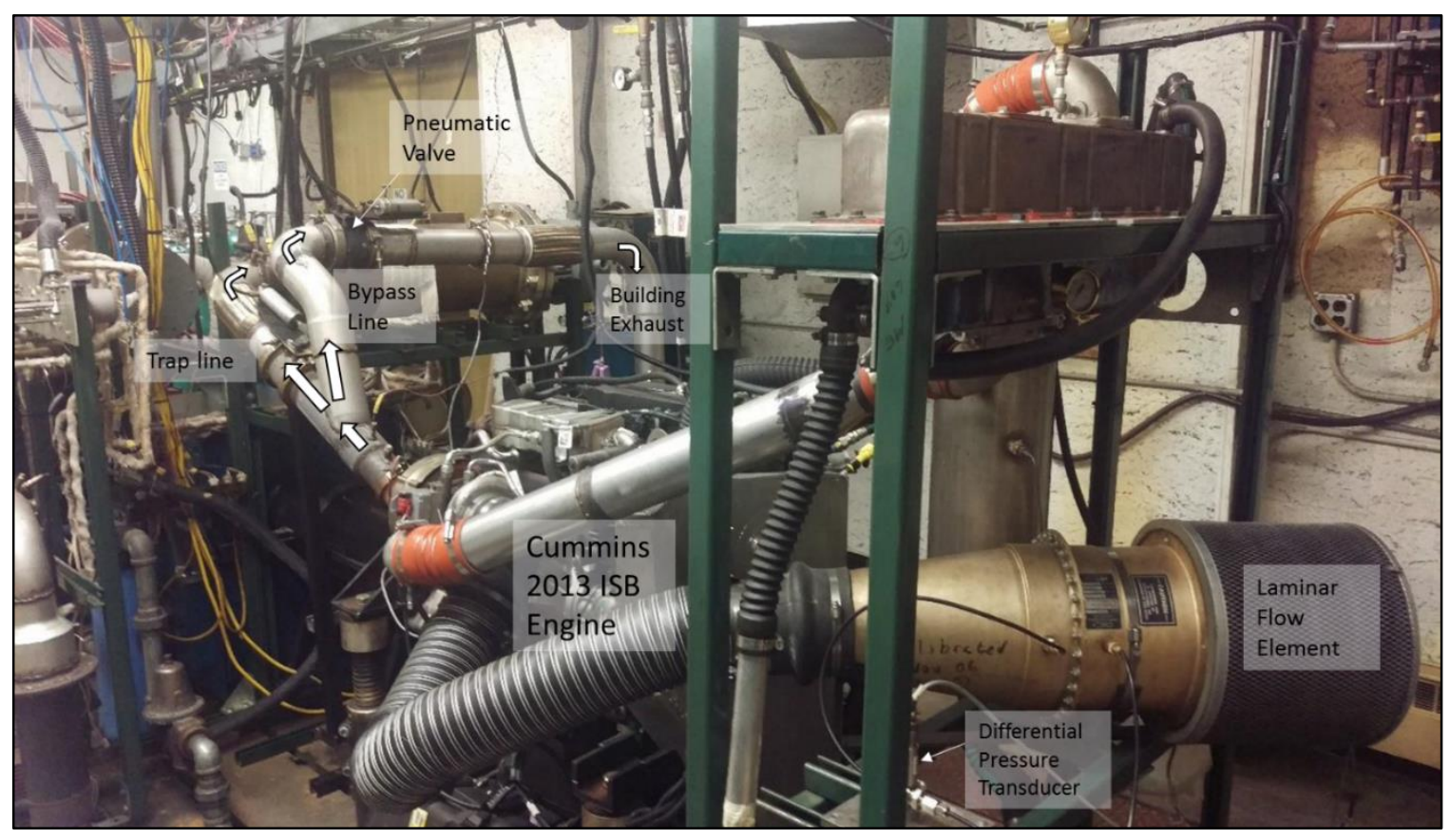

Figure 2.1 Engine system in the test cell

Ambient air was supplied to the test cell from the building ventilation system, so that the exhaust gases that might leak from any of the systems within the setup would not go in to the test cell. The engine exhaust system was maintained under a relatively negative pressure for the removal of the exhaust gases. Intake air was flown through 
the Laminar Flow Element (LFE) to the intake manifold of the engine. Exhaust coming out from the engine was diverted to the aftertreatment system by pneumatically controlled butterfly valves through the trap line as shown in Figure 2.1. The exhaust gas was then heated using an electric heater prior to going into the DOC. After the DOC, the exhaust flowed to the CPF for tests without PM loading or directly to the decomposition tube for tests with PM loading. For the latter, an empty block (called the spacer) was provided in place of the CPF. In the CPF, particulate matter was retained and oxidized. Urea in the decomposition tube was injected and the exhaust was then fed to the exhaust mixer located upstream of the $\mathrm{SCRF}^{\circledR}$ to enable proper mixing. The stream then flowed to the $\mathrm{SCRF}^{\circledR}$ and finally, the exhaust was directed through the building exhaust.

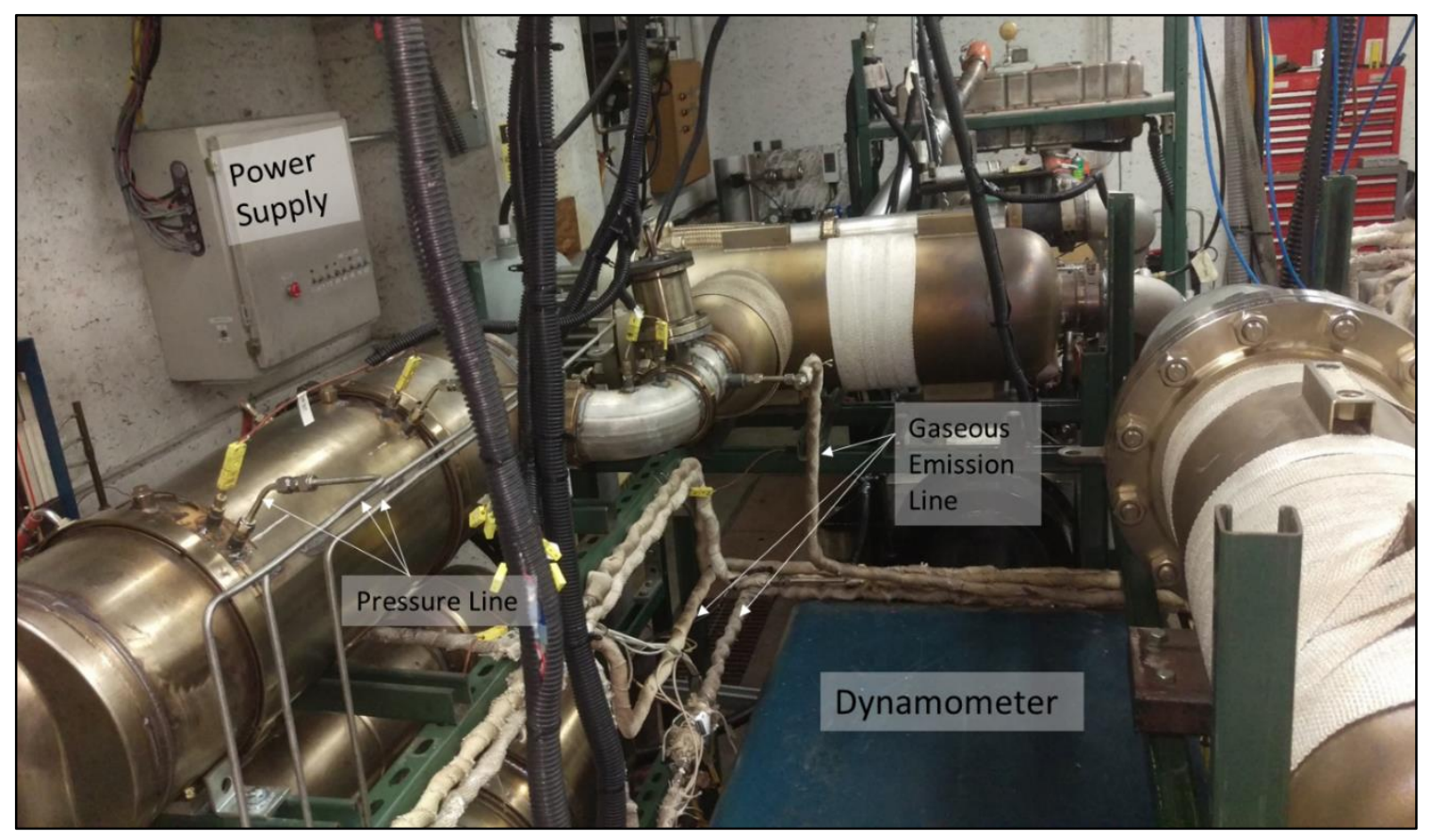

Figure 2.2 Experimental setup showing the location of sampling lines, pressure port lines, and the dynamometer in the test cell

The pressure drops across the LFE, DOC, CPF and SCRF ${ }^{\circledR}$ were measured by delta pressure transducers as shown in Figure 2.2, whereas the temperatures of the exhaust at the inlet and the outlet of components were measured by K-type thermocouples as shown in Figure 2.3. PM sampling ports were located at upstream DOC and downstream $\mathrm{SCRF}^{\circledR}$ for particulate matter sampling. Sample probes were inserted at various locations of the aftertreatment system for gaseous sampling. The probes were 
connected to a Mass Spectrometer (from V \& F Gmbh) through stainless steel sample lines. The production engine system provided various sensors to acquire information about temperature, pressure and $\mathrm{NO}_{\mathrm{x}}$ concentration in the exhaust which was communicated to the Cummins proprietary calibration tool (Calterm). The concentrations of $\mathrm{NO}_{\mathrm{x}}$ and $\mathrm{O}_{2}$ entering and leaving the aftertreatment system were measured at turbo out and $\mathrm{SCRF}^{\circledR}$ out location.

The experimental setup comprises of various components which will be described in the next parts of this section.

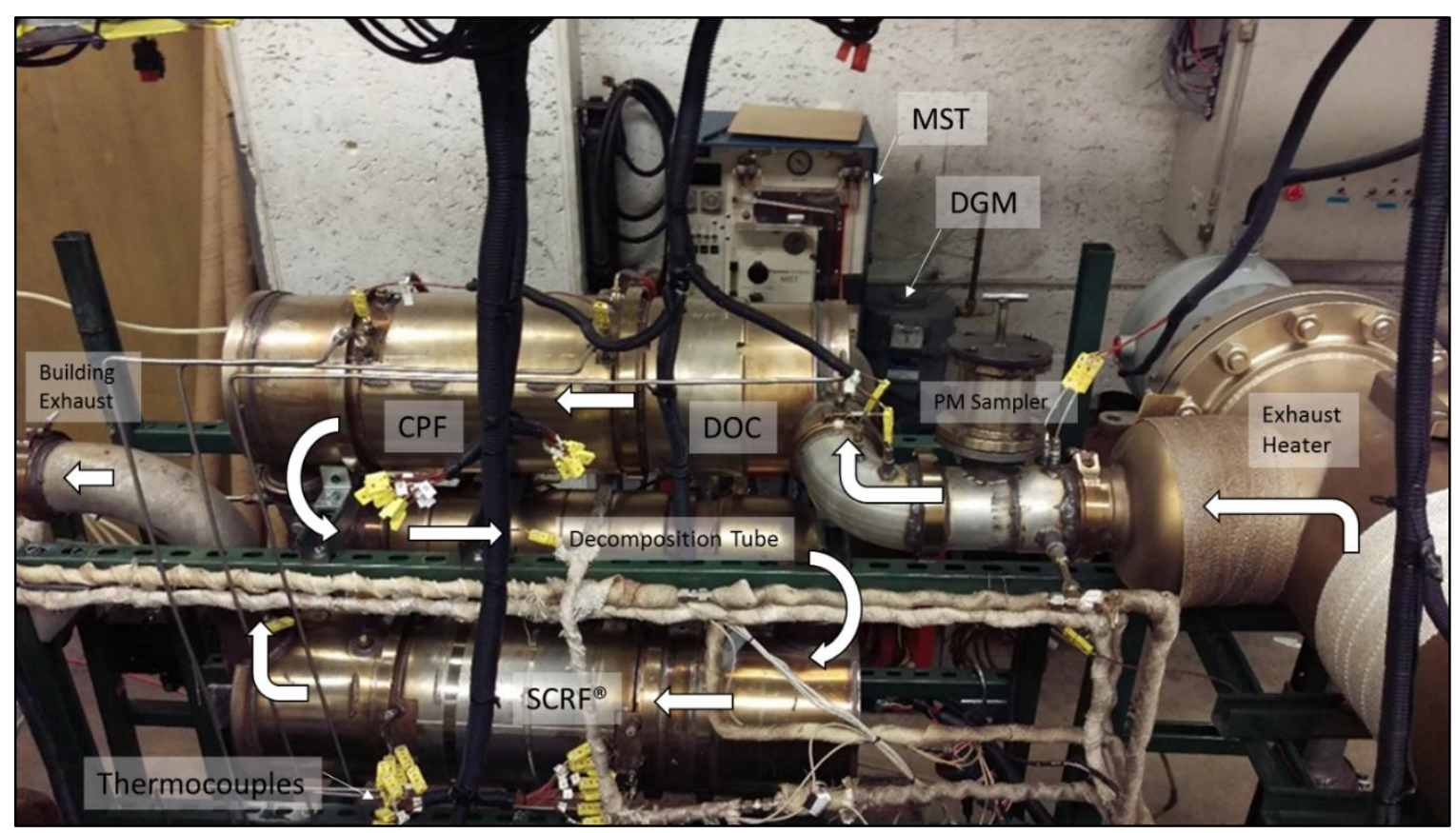

Figure 2.3 Aftertreatment system with sensors and instrumentation

\section{Engine and Dynamometer}

The test cell has the Cummins 2013 ISB engine which meets the 2013 emission standards, and 2014 greenhouse gas (GHG) and fuel efficiency regulations. The specifications of the engine are shown in Table 2.1. The engine is equipped with a High-Pressure Common Rail (HPCR) fuel injection system. A single high-capacity Electronic Control Module (ECM) controls the engine and the aftertreatment system for optimum performance and fuel efficiency [4]. 
Table 2.1 Specifications of the Cummins ISB 2013 engine

\begin{tabular}{|c|c|}
\hline Model & Cummins 2013 ISB 208 kW (280 hp) \\
\hline Bore and Stroke & 107 X 124 mm \\
\hline Displacement & $409 \mathrm{in}^{3}(6.7 \mathrm{~L})$ \\
\hline Aspiration & Turbocharged \\
\hline Controls & Electronic Control Module \\
\hline Config/Cylinders & Variable Geometry Turbocharger Inline 6 \\
cylinder
\end{tabular}

The dynamometer installed in the test cell shown in Figure 2.2 is an eddy current dynamometer with specifications shown in Table 2.2. The load and engine speed on the engine were controlled using a Digital model 1022A dynamometer controller. It can be set to two operating modes, 'Speed' and 'Load' mode. Keeping one of the parameters set to a value, the other parameter can be regulated using the throttle (potentiometer).

Table 2.2 Eddy current dynamometer specifications

\begin{tabular}{|c|c|}
\hline Manufacturer & Dynamitic \\
\hline Type of Dynamometer & Eddy Current \\
\hline Model & DM8121HS \\
\hline Power $(\mathrm{kW})$ & $373 @ 1750-7000$ RPM \\
\hline Torque $(\mathrm{Nm})$ & $2035 @ 1750$ RPM \\
\hline
\end{tabular}

\section{Aftertreatment System}

The various components of the aftertreatment system shown in Figures 1.1, and 2.3 are described below with specifications given in Table 2.3.

a) SDVs: Shutdown valves, which are pneumatically controlled butterfly valves installed in the exhaust lines to direct the exhaust coming out of the engine either towards building exhaust (through the bypass line) or towards the aftertreatment system (through the trap line) before exiting the building exhaust system. 
b) Electric Heater: Heater is required to increase the temperature of the exhaust gas passing through the trap line independent of the engine condition.

c) DOC: DOC stands for Diesel Oxidation Catalyst that is required to oxidize CO, NO, and hydrocarbons present in the exhaust stream.

d) CPF: CPF stands for Catalyzed Particulate Filter, which is incorporated in the setup as shown in Figure 2.3 to remove the PM when testing the $\mathrm{SCRF}^{\circledR}$ without PM.

e) SCRF ${ }^{\circledR}$ : It is a DPF with an SCR catalyst, which performs the function of PM filtration, $\mathrm{PM}$ oxidation, and $\mathrm{NO}_{\mathrm{x}}$ reduction. $\mathrm{SCRF}^{\circledR}$ was produced and supplied by the companies "Corning" and "Johnson Matthey".

f) Decomposition Tube: Urea solution is injected using an injector in the decomposition tube so that it gets decomposed to $\mathrm{NH}_{3}$, which then enters the $\mathrm{SCRF}^{\circledR}$.

g) Exhaust Mixer: Its function is to ensure proper mixing and in turn provide an exhaust gas mixture for accurate measurements.

Table 2.3 Specifications of the DOC, CPF and SCRF ${ }^{\circledR}$

\begin{tabular}{|c|c|c|c|}
\hline Substrate & DOC & CPF & SCRF $^{\circledR}$ \\
\hline Material & Cordierite & Cordierite & Cordierite \\
\hline Diameter (inch) & 9 & 9 & 10.5 \\
\hline Length (inch) & 4 & 10 & 12 \\
\hline Cell Geometry & Square & Square & Square \\
\hline Total Volume (L) & 4.17 & 10.4 & 17.04 \\
\hline Open Volume (L) & 3.5 & 7.3 & 10.2 \\
\hline Cell Density/in ${ }^{2}$ & 400 & 200 & 200 \\
\hline Cell Width (mil) & 46 & 59 & 55 \\
\hline Filtration Area (in $\left.{ }^{2}\right)$ & N/A & 9886 & 11370 \\
\hline Open Frontal Area (in²) & 53.9 & 24.7 & 25.9 \\
\hline Channel Wall Thickness (mil) & 4 & 12 & 16 \\
\hline Porosity (\%) & 35 & 59 & 50 \\
\hline Mean Pore Size $(\mu \mathrm{m})$ & N/A & 15 & 16 \\
\hline Numbers of Cells & 25447 & 12723 & 17318 \\
\hline Number of Inlet Cells & 25447 & 6362 & 8659 \\
\hline
\end{tabular}




\subsection{Fuel Properties}

For the testing, Ultra Low Sulphur Diesel Number 2 (ULSD \#2) summer blend fuel was used that was supplied to MTU by Krans Oil at Lake Linden, MI. Since the fuel used for the testing in this report was the same as that for the CPF testing, fuel properties data in Table 2.4 were taken from reference [2].

Table 2.4 Specification of fuel used for testing [2]

\begin{tabular}{|c|c|}
\hline Fuel Type & ULSD -2 \\
\hline API. Gravity at $15.6^{\circ} \mathrm{C}$ & 35.4 \\
\hline SP. Gravity at $15.6^{\circ} \mathrm{C}$ & 0.848 \\
\hline Viscosity at $40^{\circ} \mathrm{C}$ (cst) & 3 \\
\hline Total Sulfur (ppm) & 7 \\
\hline Initial Boiling Point $\left({ }^{\circ} \mathrm{C}\right)$ & 184 \\
\hline Final Boiling Point $\left({ }^{\circ} \mathrm{C}\right)$ & 363 \\
\hline Cetane Index & 48.7 \\
\hline Water Content (ppm) & 34 \\
\hline Higher Heating Value $^{1}[\mathrm{MJ} / \mathrm{kg}]$ & 45.68 \\
\hline Lower Heating Value ${ }^{1}[\mathrm{MJ} / \mathrm{kg}]$ & 42.89 \\
\hline $\mathrm{H} / \mathrm{C}^{1}$ & 1.833 \\
\hline
\end{tabular}

1 These values were obtained from reference [5] since they were not available from the analysis at Cummins.

\subsection{Test Cell Instrumentation}

The test cell is installed with various instruments and sensors to acquire data as described in this section. The parameters were measured, logged and displayed using the Data Acquisition System.

\section{Air and Fuel Flow Measurement}

The air flow into the intake system of the engine was measured by a Meriam Instruments Laminar Flow Element (Model number 50MC2-06F). The flow rate was calculated using the pressure drop data and the ambient temperature and humidity. The accuracy was in the range of $0.72 \%$ to $0.86 \%$ with repeatability of $0.1 \%$.

The fuel flow rate was measured by the Micromotion flowmeter installed in the laboratory. The exhaust flow is the sum of the air flow and fuel flow rate. The exhaust mass flow was also indicated by the engine ECM. 


\section{Pressure Measurement}

The pressure drop across the LFE, the DOC, and the SCRF ${ }^{\circledR}$ was measured using differential pressure transducers. The specifications of the pressure transducer used for the air flow and various components in the aftertreatment system is given in Table 2.5 .

Table 2.5 Specifications of pressure transducer

\begin{tabular}{|c|c|c|c|c|}
\hline Sensor Brand & $\begin{array}{c}\Delta \text { LFE } \\
\text { Omega } \\
\text { Engineering }\end{array}$ & $\begin{array}{c}\Delta \text { Om DOC } \\
\text { Engineering }\end{array}$ & $\begin{array}{c}\Delta \text { Om CPF } \\
\text { Ongineering }\end{array}$ & $\begin{array}{c}\Delta \text { P SCRF }^{\circledR} \\
\text { Omega } \\
\text { Engineering }\end{array}$ \\
\hline Model Number & $\begin{array}{c}\text { PX-429- } \\
\text { 10WDW10 } \\
\mathrm{V}\end{array}$ & $\begin{array}{c}\text { PX-409- } \\
2.5 \mathrm{DWU} 5 \mathrm{~V}\end{array}$ & $\begin{array}{c}\text { PX-429- } \\
2.5 \mathrm{DWU} 10 \mathrm{~V}\end{array}$ & $\begin{array}{c}\text { PX-429- } \\
005 \mathrm{DWU} 10 \mathrm{~V}\end{array}$ \\
\hline Sensor Type & Differential & Differential & Differential & Differential \\
\hline Range & $0-10$ & $0-17.24$ & $0-17.25$ & $0-34.47$ \\
\hline $\begin{array}{c}\text { Units } \\
\text { in. } \mathrm{H}_{2} \mathrm{O}\end{array}$ & $\mathrm{kPa}$ & $\mathrm{kPa}$ & $\mathrm{kPa}$ \\
\hline $\begin{array}{c}\text { Output Voltage } \\
\text { Range (V) }\end{array}$ & $0-10$ & $0-10$ & $0-10$ & $0-10$ \\
\hline
\end{tabular}

\section{Temperature Measurement}

An Omega HX94V temperature and relative humidity $(\mathrm{RH})$ transmitter were used to measure ambient temperature and humidity of the test cell. The accuracy of temperature measurement was $\pm 0.6 \%$ with a repeatability of $\pm 0.3 \%$. The accuracy of $\mathrm{RH}$ measurement was $\pm 0.2 \%$ and a repeatability of $\pm 1 \%$.

The exhaust gas temperatures at different locations of the engine and aftertreatment system were measured using K-type thermocouples with the specifications as shown in Table 2.6. In the $\mathrm{SCRF}^{\circledR}$, thermocouples were arranged in axial and radial positions at the upstream and downstream locations as shown in Figure 2.4. The inlet of the $\mathrm{SCRF}^{\circledR}$ had thermocouples named S1 to S5 whereas the outlet had thermocouples named S16 to S20. The thermocouple temperature readings were used to analyze temperature distribution in the $\mathrm{SCRF}^{\circledR}$. 


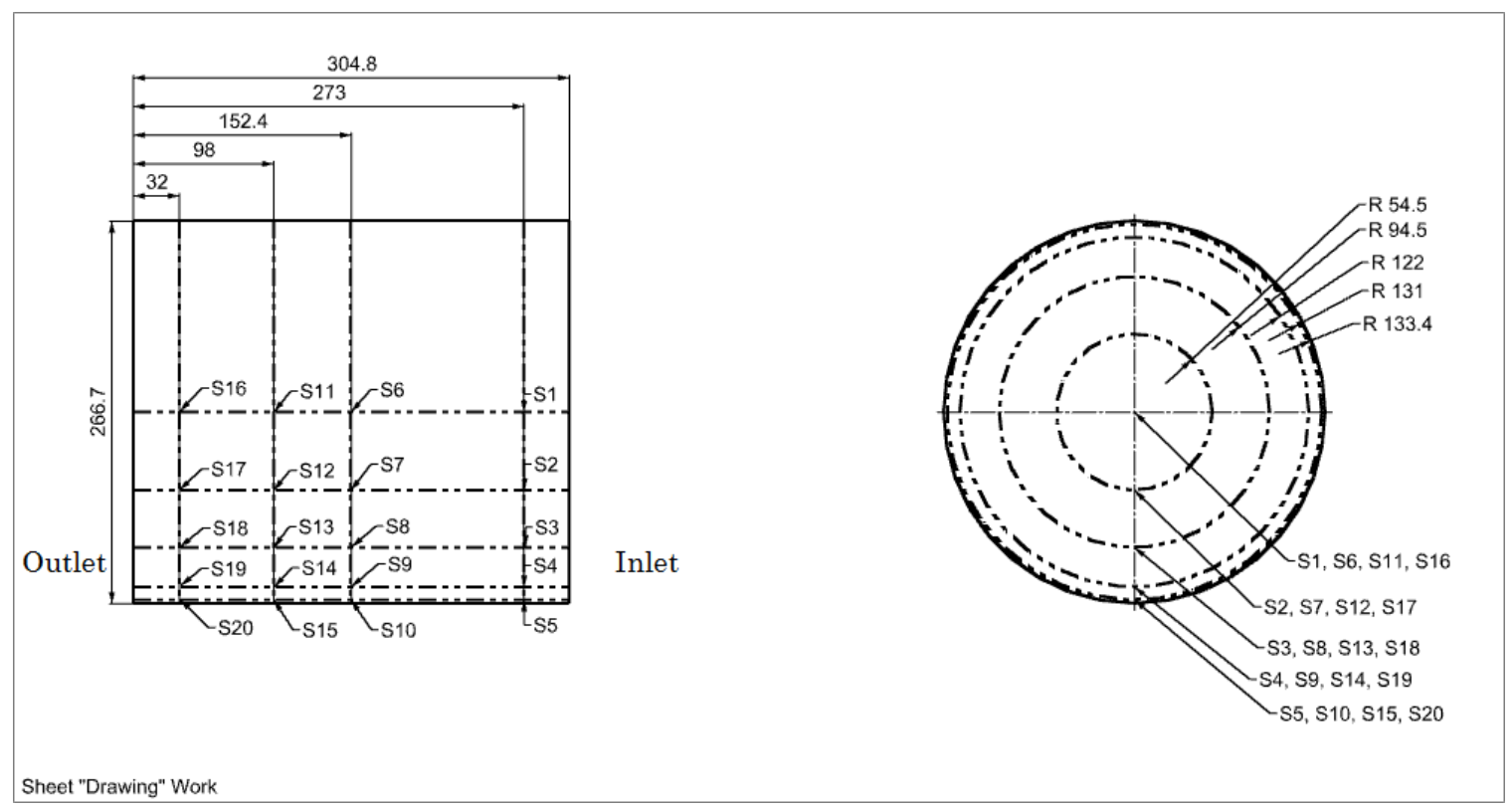

Figure 2.4 $\mathrm{SCRF}^{\circledR}$ thermocouple arrangement - Dimensions are in $\mathrm{mm}$

Table 2.6 Specification of thermocouples

\begin{tabular}{|c|c|c|c|c|c|}
\hline Manufacturer & Location & Diameter & Length & Part\# & Accuracy \\
\hline$[-]$ & {$[-]$} & {$[$ in.] } & [in.] & {$[-]$} & {$[\%]$} \\
\hline Omega & $\begin{array}{c}\text { Air Intake, } \\
\text { Exhaust stream, } \\
\text { Coolant }\end{array}$ & 0.125 & 6 & KMQSS125U-6 & $\pm 2.2{ }^{\circ} \mathrm{C}$ \\
\hline Omega & $\mathrm{SCRF}^{\circledR}$ & 0.02 & 12 & $\begin{array}{c}\text { K-MQSS-020-U- } \\
12\end{array}$ & $\pm 2.2{ }^{\circ} \mathrm{C}$ \\
\hline Omega & $\mathrm{SCRF}^{\circledR}$ & 0.02 & 16 & $\begin{array}{c}\text { K-MQSS-020-U- } \\
16\end{array}$ & $\pm 2.2{ }^{\circ} \mathrm{C}$ \\
\hline
\end{tabular}

\section{Data Acquisition}

The measured values of temperature, pressure, speed and load were measured and communicated to desktop computers using National Instruments DAQ chassis (two NI CDAQ-9178). The fuel flow measured by Micro Motion Coriolis flow meter was communicated via RS-485 driver using the transmitter. [5]

NI Labview interface was used on the desktop computer in the control room to log the acquired data and to operate the electro-pneumatic butterfly valves for exhaust sampling from different locations. Engine data was acquired via CAN communication (J1939 protocol) with the ECM. Calterm was used to display and control various parameters of the engine. 


\section{Emissions Measurement}

The emission samples were collected from three locations i.e. upstream DOC, upstream $\mathrm{SCRF}^{\circledR}$, and downstream $\mathrm{SCRF}^{\circledR}$ as shown in Figure 2.2. The samples were directed to the Mass Spectrometer located in the control room to analyze the concentration of gas species in the exhaust system. The V\&F air sense Ion Molecule Reaction Mass Spectrometer (IMR-MS) was used to determine the concentration of $\mathrm{NO}, \mathrm{NO}_{2}$, and $\mathrm{NH}_{3}$. The specifications of the IMR-MS is given in Table 2.7.

Table 2.7 Specifications of IMR-MS

\begin{tabular}{|c|c|c|c|c|c|c|}
\hline Components & $\begin{array}{c}\text { Detection level } \\
\text { at } 100 \mathrm{~ms}\end{array}$ & $\begin{array}{c}\text { Monitoring } \\
\text { mass }\end{array}$ & Ionizator & $\begin{array}{c}\text { Span } \\
\text { Gas }\end{array}$ & $\begin{array}{c}\text { Span gas } \\
\text { concen- } \\
\text { tration }\end{array}$ & Accuracy \\
\hline$[-]$ & {$[\mathrm{ppb}]$} & {$[\mathrm{amu}]$} & {$[-]$} & {$[-]$} & [ppm] & {$[\%]$} \\
\hline $\mathrm{NO}$ & 100 & 30 & $\mathrm{Hg}$ & $\mathrm{NO}, \mathrm{N}_{2}$ & 515.4 & \pm 1 \\
\hline $\mathrm{NO}_{2}$ & 50 & 46 & $\mathrm{Hg}$ & $\mathrm{NO}_{2}, \mathrm{Air}$ & 99.05 & \pm 2 \\
\hline $\mathrm{NH}_{3}$ & 120 & 17 & $\mathrm{Hg}$ & $\begin{array}{c}\mathrm{NH}_{3}, \mathrm{~N}_{2} \\
\text { balance }\end{array}$ & 103.8 & \pm 2 \\
\hline
\end{tabular}

The two $\mathrm{NO}_{\mathrm{x}}$ and $\mathrm{NO}_{\mathrm{x}} / \mathrm{O}_{2}$ sensors from the production aftertreatment system were used to take $\mathrm{NO}_{\mathrm{x}}$ measurements. The sensor consists of an NGK sensing element with a Continental control unit. The measured value is displayed through Calterm.

\section{Particulate Matter Sampling and Measurement}

A PM filter (A/E type $47 \mathrm{~mm}$ diameter, glass fiber, manufactured by Pall Corporation, WA) was used to collect PM in the exhaust at upstream DOC and downstream SCRF ${ }^{\circledR}$ location in the aftertreatment system. The Dry Gas Meter (DGM) was connected to the Manual Sampling Train (MST) as shown in Figure 2.3.

The MST is equipped with a vacuum gauge, K-type thermocouples, a DGM, a manometer and a timer to determine the value of sample pump vacuum, temperature, volume of exhaust gas sampled, pressure drop and time respectively. The duration, volume and temperature of exhaust sampled was measured using the data from the dry gas meter. The mass of the PM sampled on the glass fiber filter is weighed using a Mettler Toledo UMT2 microbalance. The procedure of sampling and PM filter weighing is given in Appendix A.

The specification of the weighing scale is given in Table 2.8 . 
Table 2.8 Specifications of Mettler Toledo UMT2 microbalance [2]

\begin{tabular}{|c|c|}
\hline Readability & $0.1 \mu \mathrm{g}$ \\
\hline Weight capacity & $2100 \mathrm{mg}$ \\
\hline Repeatability & $0.25 \mu \mathrm{g}$ \\
\hline Linearity & $\pm 1 \mathrm{\mu g}$ \\
\hline $\begin{array}{c}\text { Linearity referred to } \\
\text { 500 mg }\end{array}$ & $\pm 0.5 \mathrm{\mu g}$ \\
\hline $\begin{array}{c}\text { Stabilization Time } \\
\text { setting }\end{array}$ \\
\hline $\begin{array}{c}\text { Sensitivity Drift (5-40 } \\
\left.{ }^{\circ} \mathbf{C}\right)\end{array}$ & $\pm 0.00015 \%$ \\
\hline
\end{tabular}

The PM retained in the $\mathrm{SCRF}^{\circledR}$ in the tests during PM loading was measured. The engine was shut down and the loading in the SCRF® was weighed during the test procedure. The mass measurement was done on an Ohaus Ranger Scale and the specifications of the scale are given in Table 2.9. The detailed procedure to weigh the $\mathrm{SCRF}^{\circledR}$ is given in Appendix B.

Table 2.9 Specifications of weighing apparatus [2]

\begin{tabular}{|c|c|}
\hline Manufacturer & Ohaus \\
\hline Model & Ranger RD35LM \\
\hline Capacity & $35 \mathrm{~kg}$ \\
\hline Resolution & $0.1 \mathrm{~g}$ \\
\hline Repeatability & $\pm 0.1 \mathrm{~g}$ \\
\hline Certified Accuracy & $\pm 1.0 \mathrm{~g}$ \\
\hline
\end{tabular}

\subsection{Test Points}

The test cell setup and instruments described in Sections 2.1 and 2.3 were used to collect the data to analyze $\mathrm{NO}_{x}$ reduction efficiency and $\mathrm{NH}_{3}$ slip of the $\mathrm{SCRF}^{\circledR}$ in the aftertreatment system. To achieve this goal, the engine was run at test points, selected from the test matrix of baseline SCR, as shown in Table 2.10. The engine conditions were decided from the table so as to obtain flow rate, space velocities, $\mathrm{SCRF}^{\circledR}$ inlet temperatures and $\mathrm{NO}_{\mathrm{x}}$ out of the engine which are same as in the experiments performed for baseline SCR testing of the production system [6]. 
The test points were selected in order to determine the $\mathrm{NO}_{\mathrm{x}}$ reduction performance of the $\mathrm{SCRF}^{\circledR}$ over a range of $\mathrm{NO}_{2} / \mathrm{NO}_{\mathrm{x}}$ ratios at different $\mathrm{SCRF}^{\circledR}$ inlet temperatures and space velocities. The test points $1,3,6$, and 8 were selected out of the table matrix for the tests in this report which cover both the lower and higher values of SCRF ${ }^{\circledR}$ inlet temperatures and inlet $\mathrm{NO}_{2} / \mathrm{NO}_{\mathrm{x}}$ ratio. The different $\mathrm{SCRF}^{\circledR}$ conditions were achieved by varying engine conditions and heater temperature. The ammonia to $\mathrm{NO}_{\mathrm{x}}$ ratios (ANRs) were set based on the urea dosing cycle developed for conducting the tests. This allowed for calibration of the model for similar exhaust conditions. At the same time, these points cover a range of inlet $\mathrm{NO}_{2} / \mathrm{NO}_{\mathrm{x}}$ ratios.

Table 2.10 Test matrix of baseline SCR tests for $\mathrm{NO}_{\mathrm{x}}$ reduction experiments

\begin{tabular}{|c|c|c|c|c|c|c|c|c|}
\hline $\begin{array}{l}\text { Test } \\
\text { Point }\end{array}$ & Speed & Torque & $\begin{array}{c}\text { Exhaust } \\
\text { Flow } \\
\text { rate }\end{array}$ & $\begin{array}{c}\text { SCR } \\
\text { Inlet } \\
\text { Temp. }\end{array}$ & $\begin{array}{c}\text { SCR Std. } \\
\text { Space } \\
\text { Vel. }\end{array}$ & $\begin{array}{l}\mathrm{SCR} \\
\text { Inlet } \\
\mathrm{NO}_{2}\end{array}$ & $\begin{array}{l}\text { SCR } \\
\text { Inlet } \\
\mathrm{NO}_{\mathrm{x}}\end{array}$ & $\begin{array}{l}\mathrm{SCR} \text { Inlet } \\
\mathrm{NO}_{2} / \mathrm{NO}_{\mathrm{x}}\end{array}$ \\
\hline$[-]$ & [RPM] & {$[\mathrm{N}-\mathrm{m}]$} & {$[\mathrm{kg} / \mathrm{min}]$} & {$\left[{ }^{\circ} \mathrm{C}\right]$} & {$[\mathrm{k} / \mathrm{hr}]$} & {$[-]$} & {$[\mathrm{ppm}]$} & {$[-]$} \\
\hline $1^{*}$ & 1200 & 203 & 4.9 & 208 & 14.6 & 301 & 492 & 0.61 \\
\hline 2 & 1650 & 203 & 6.5 & 231 & 19.4 & 184 & 306 & 0.6 \\
\hline $3^{*}$ & 2200 & 325 & 10 & 310 & 29.9 & 217 & 341 & 0.64 \\
\hline 4 & 2100 & 377 & 0.4 & 331 & 28.1 & 230 & 372 & 0.62 \\
\hline 5 & 1660 & 529 & 7.8 & 353 & 23.3 & 356 & 662 & 0.54 \\
\hline $6^{*}$ & 1200 & 580 & 6.4 & 354 & 19.1 & 922 & 1712 & 0.54 \\
\hline 7 & 2100 & 750 & 13 & 404 & 38.8 & 242 & 546 & 0.44 \\
\hline $8^{*}$ & 2400 & 813 & 16 & 455 & 47.8 & 233 & 596 & 0.39 \\
\hline
\end{tabular}

* The test points marked with asterisk (*) were selected for conducting the $\mathrm{SCRF}^{\circledR}$ tests in the report.

\subsection{Test Procedure}

The aftertreatment system configuration studied in this work includes a DOC, CPF, and $\mathrm{SCRF}^{\circledR}$, where the experiments were aimed to determine the $\mathrm{NO}_{\mathrm{x}}$ reduction of the $\mathrm{SCRF}^{\circledR}$. The tests for the $\mathrm{SCRF}^{\circledR}$ were performed with 0,2 , and $4 \mathrm{~g} / \mathrm{L}$ (grams of PM per volume of the $\mathrm{SCRF}^{\circledR}$ ). The test procedure planned to conduct the testing included $\mathrm{SCRF}^{\circledR}$ cleanout stage to remove PM completely from the $\mathrm{SCRF}^{\circledR}, \mathrm{PM}$ Loading stage to load PM into the $\mathrm{SCRF}^{\circledR}$, and $\mathrm{NO}_{\mathrm{x}}$ reduction stage to analyze the $\mathrm{SCRF}^{\circledR} \mathrm{NO}_{\mathrm{x}}$ reduction performance and $\mathrm{NH}_{3}$ slip at a particular engine condition. The engine conditions for test point $1,3,6$, and 8 discussed in Section 2.4 were run for $\mathrm{NO}_{\mathrm{x}}$ reduction stage. Loading stages were eliminated for tests without PM loading. The CPF was placed to filter the PM after the DOC and upstream of $\mathrm{SCRF}^{\circledR}$ (see Figure 
1.1) during the $\mathrm{NO}_{\mathrm{x}}$ reduction stage. The air intake temperature was controlled at $50^{\circ} \pm$ $2^{\circ} \mathrm{C}$ by directing the building water supply to the heat exchanger for cooling the air. The PM loading of the $\mathrm{SCRF}^{\circledR}$ test procedure is similar to the procedure used in the past for baseline CPF testing [2]. The rail pressure was reduced by $30 \%$ to increase the engine-out PM and to load PM in a practical time (330 minutes).

\section{Tests with PM Loading in the SCRF ${ }^{\circledR}$}

Figure 2.5 shows the schematic representation of the test sequence for PM loading in the $\mathrm{SCRF}^{\circledR}$.

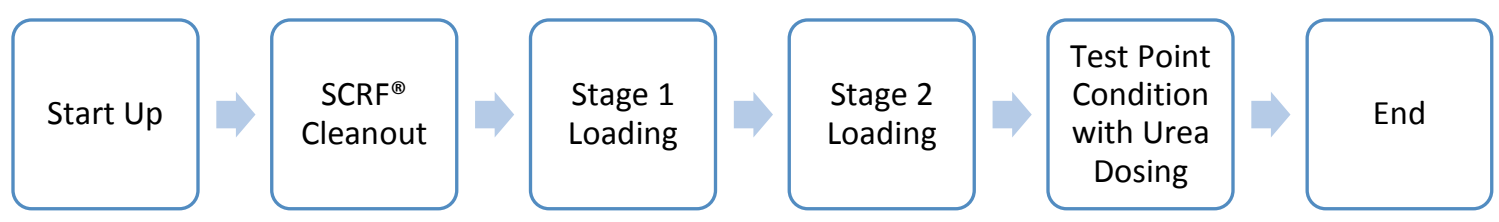

Figure 2.5 Schematic representation of the process of testing with PM loading in the SCRF ${ }^{\circledR}$

Experiments were conducted in different stages as mentioned below:

\section{Start Up and SCRF ${ }^{\circledR}$ Cleanout}

The engine was warmed up by running it at 900 RPM at idle load conditions for 3 to 5 minutes and readings of data displayed on Labview and Calterm were checked for correctness. The engine was then raised to a higher speed of $1200 \mathrm{RPM}$ at $200 \mathrm{Nm}$ load in the subsequent 2 minutes. The engine was then brought to an intermediate engine condition (1600 RPM and $475 \mathrm{Nm}$ load). The engine was run in this state for 30 minutes to have stabilized engine out emission samples. Parameters were again noted in this condition to check for variations.

$\mathrm{PM}$ accumulated in the $\mathrm{SCRF}^{\circledR}$ was cleaned out using in-cylinder fuel dosing that raises the temperature for the PM oxidation process. The fuel was dosed at 36 $\mathrm{mg} /$ stroke. The temperature was maintained above $550^{\circ} \mathrm{C}$ at the upstream $\mathrm{SCRF}^{\circledR}$ location for complete clean out. The slope of pressure drop displayed on Labview interface reaches a balance point (a point where the rate of PM oxidation and accumulation are the same) with time, thus concluding the clean out stage. 


\section{Particulate Matter Loading}

The particulate matter loading was done in two stages, Stage 1 and Stage 2. The selection of the loading test condition was taken from reference [2]. The loading conditions were decided based on exhaust mass flow rates, space velocities, PM concentrations, and $\mathrm{NO}_{\mathrm{x}} / \mathrm{PM}$ ratios to achieve $\mathrm{PM}$ loading in a reasonable amount of time.

In Stage 1, the engine load condition was changed to $2400 \mathrm{RPM}$ and $218 \mathrm{Nm}$ after the completion of the $\mathrm{SCRF}^{\circledR}$ cleanout stage. The emission samples were taken at upstream DOC (UDOC), upstream SCRF® (USCRF), and downstream SCRF ${ }^{\circledR}$ (DSCRF). For PM analysis, samples were collected at UDOC and DSCRF ${ }^{\circledR}$. Loading was done for 30 minutes. The exhaust was then directed to the 'bypass' line, the engine was shut down and the $\mathrm{SCRF}^{\circledR}$ was disassembled from the aftertreatment system and weighed by the procedure as discussed in Appendix B. The weight of the $\mathrm{SCRF}^{\circledR}$ changes with temperature and hence consistency was maintained by recording the temperature of the $\mathrm{SCRF}^{\circledR}$ thermocouples above $220 \pm 20{ }^{\circ} \mathrm{C}$ (shown in Figure 2.3) prior to weighing.

The $\mathrm{SCRF}^{\circledR}$ was assembled back into the system and the engine was restarted for Stage 2 loading. The engine was brought to the same condition as that of Stage 1 loading condition. Once the engine-out temperature had stabilized, exhaust was routed to the 'trapline' using the pneumatic valve.

In Stage 2 loading, the engine was run until the system was loaded to 2 or $4 \mathrm{~g} / \mathrm{L}$. It took 330 and 500 minutes approximately for 2 and $4 \mathrm{~g} / \mathrm{L}$ respectively. Emissions were sampled at UDOC, USCRF and DSCRF locations for a duration of approximately 60 minutes each and PM was sampled at UDOC and DSCRF location for a duration of 10 and 60 minutes respectively. After the loading, exhaust was shifted to the 'bypass' line and the same shut down procedure was adopted.

\section{3. $\mathrm{NO}_{\mathrm{x}}$ Reduction}

The purpose of this stage is to observe the $\mathrm{NO}_{\mathrm{x}}$ reduction capability of the $\mathrm{SCRF}^{\circledR}$ at each of the engine conditions mentioned in Section 2.4 over a range of $\mathrm{NO}_{2} / \mathrm{NO}_{\mathrm{x}}$ ratios and $\mathrm{NH}_{3} / \mathrm{NO}_{\mathrm{x}}$ ratios (ANR) at the inlet of the $\mathrm{SCRF}^{\circledR}$ at different $\mathrm{SCRF}^{\circledR}$ inlet temperatures and space velocities. It was done by injecting an appropriate amount of 
urea to achieve desired ANR values. The urea dosing cycle depicts $\mathrm{SCRF}^{\circledR}$ inlet $\mathrm{ANR}$ values $(0.8,1,1.2$, and 1.2 repeat) and their sequence adopted, for the study of transient response of $\mathrm{ANR}$ on $\mathrm{NO}_{\mathrm{x}}$ reduction efficiency and $\mathrm{NH}_{3}$ slip, as shown in Figure 2.4. The ANR values around 1 were selected to study for high $\mathrm{NO}_{\mathrm{x}}$ reduction efficiencies.

The engine conditions were similar to those used for SCR testing as was discussed in Section 2.4. Since flow rates and temperatures were similar, the conversion efficiency of the DOC should produce similar amounts of $\mathrm{NO}_{2}$ and the $\mathrm{SCRF}^{\circledR}$ inlet $\mathrm{NO}_{2} / \mathrm{NO}_{\mathrm{x}}$ ratio should be similar. The engine was run at test points $1,3,6$, and 8 for the study of the effects of PM loading on $\mathrm{NO}_{\mathrm{x}}$ reduction as discussed in Section 2.4. Test points 1 and 3 (218 and $304{ }^{\circ} \mathrm{C}$ ) have less PM oxidation during the urea dosing cycle whereas test points 6 and $8\left(354\right.$ and $455{ }^{\circ} \mathrm{C}$ ) have higher $\mathrm{PM}$ oxidation during the same. The PM was added and oxidized simultaneously in the SCRF $^{\circledR}$ during these engine conditions. The rate of $\mathrm{PM}$ oxidation is higher for high inlet $\mathrm{SCRF}^{\circledR}$ temperatures and vice versa. At higher temperatures, PM loading was done in the $\mathrm{SCRF}^{\circledR}$ to maintain the PM concentration at approximately 2 or $4 \mathrm{~g} / \mathrm{L}$ in the $\mathrm{SCRF}^{\circledR}$. Figure 2.6 shows the two loading stages represented by "Repeated loading-I" and "Repeated loading-II" done in the test point $6 \mathrm{NO}_{\mathrm{x}}$ reduction stage in order to maintain $2 \mathrm{~g} / \mathrm{L}$ in the $\mathrm{SCRF}^{\circledR}$. The urea is dosed in order to obtain required ANR values during the repeated loading stages as shown in Figure 2.6.

The engine was run at set conditions with urea dosing in the decomposition tube to get particular $\mathrm{SCRF}^{\circledR}$ inlet temperatures and $\mathrm{ANR}$ values. The emission samples were taken from upstream and downstream locations of the $\mathrm{SCRF}^{\circledR}$ and upstream location of DOC with a mass spectrometer. The sampling was done for each of these ANR values for approximately 20 minutes until stabilized $\mathrm{NO}_{\mathbf{x}}$ concentration and $\mathrm{NH}_{3}$ slip was achieved at the downstream $\mathrm{SCRF}^{\circledR}$ location. The dosing rate was then changed to achieve different ANR values and downstream SCRF ${ }^{\circledR}$ measurements were taken. The process was repeated for the rest of the ANR values as per the urea dosing cycle in Figure 2.7. Once the required ANR points were achieved, the engine was brought back to baseline condition, then down to idle and then shut down. 


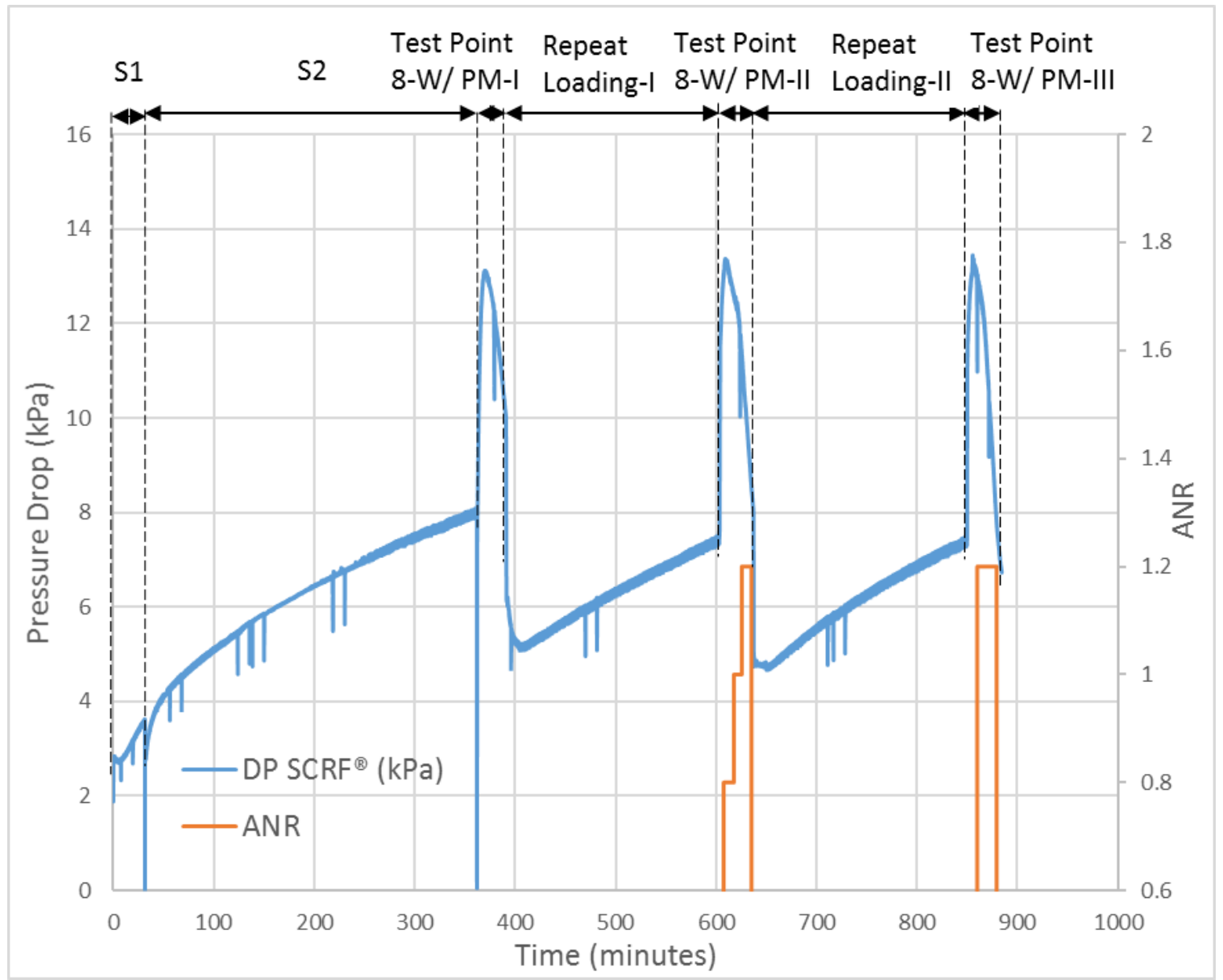

Figure 2.6 Pressure drop curve for Stage 1, Stage 2 and repeat loading in between the $\mathrm{NO}_{\mathrm{x}}$ Reduction Stage

The species concentration was calculated by averaging out the stable range of the sample. The ANR value of 1.2 was repeated in the urea dosing cycle, to obtain further empirical data for $\mathrm{NH}_{3}$ adsorption measurement and to ensure repeatability, as shown in Figure 2.7. The PM sample was taken at UDOC with the Manual Sampling Train. Its concentration was maintained at $2.0 \pm 0.2$ or $4.0 \pm 0.4 \mathrm{~g} / \mathrm{L}$ in the $\mathrm{SCRF}^{\circledR}$ by loading it in between the urea dosing cycle (whenever necessary) for high SCRF ${ }^{\circledR}$ inlet temperature test points (test point 6 and 8 for $2 \mathrm{~g} / \mathrm{L}$ and $4 \mathrm{~g} / \mathrm{L}$ ). The loading was done at the engine conditions described in Particulate Matter Loading section to load $\mathrm{SCRF}^{\circledR}$ up to the desired 2 or $4 \mathrm{~g} / \mathrm{L} \mathrm{PM}$ concentration. The $\mathrm{SCRF}^{\circledR}$ was then weighed to confirm the PM concentration. 


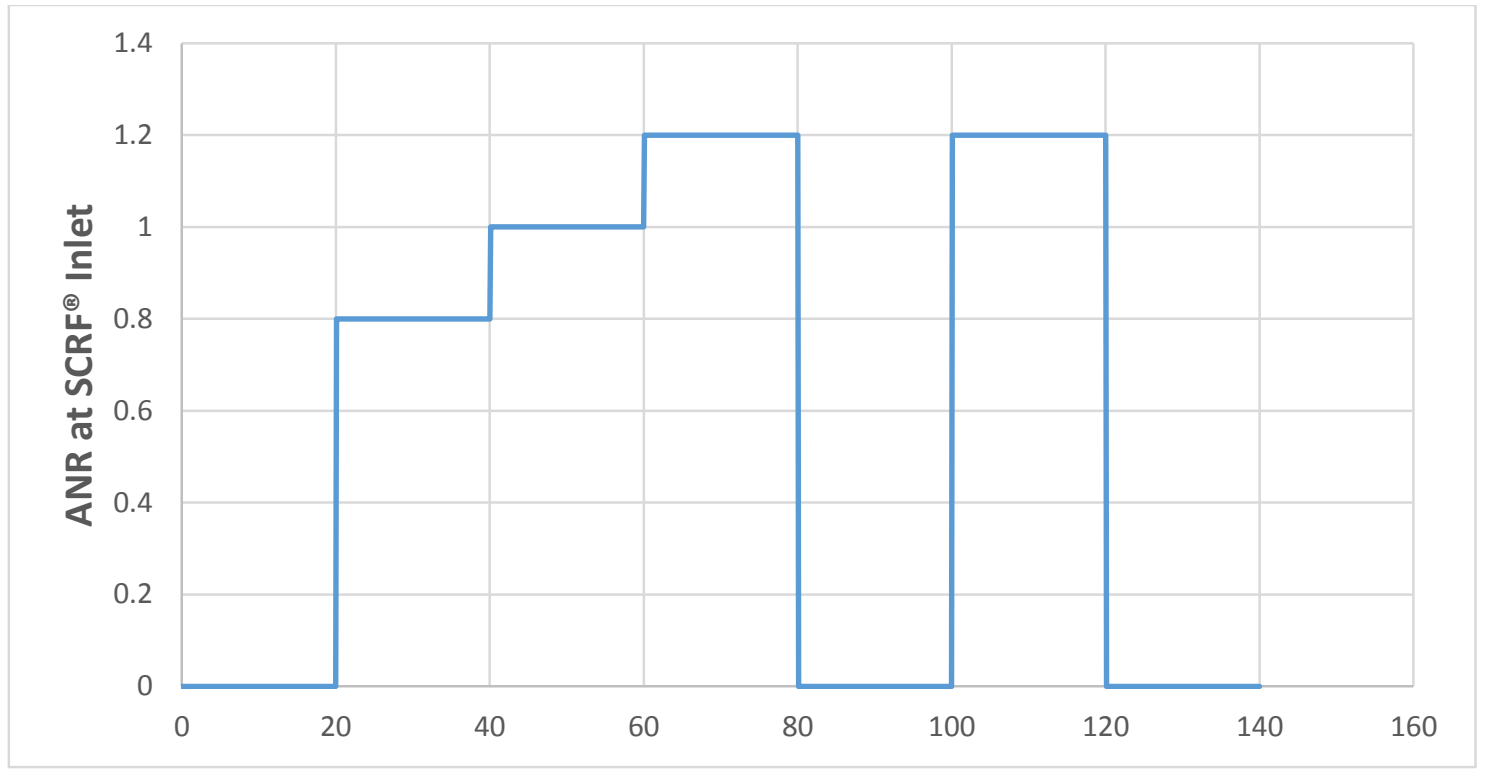

Figure 2.7 Urea dosing cycle for $\mathrm{SCRF}^{\circledR}$

\section{Tests without PM Loading in the SCRF ${ }^{\circledR}$}

The test procedure to perform $\mathrm{NO}_{\mathrm{x}}$ reductions in the $\mathrm{SCRF}^{\circledR}$ without $\mathrm{PM}$ is different from tests with PM loading in the sense that the CPF is placed downstream of the DOC to filter PM loading. This was done so as to reduce the possibility of PM interfering with the $\mathrm{NH}_{3}$ adsorption capacity of the $\mathrm{SCRF}^{\circledR}$ as shown in Figure 2.8. The stages for these tests consist of $\mathrm{SCRF}^{\circledR}$ cleanout and $\mathrm{NO}_{\mathrm{x}}$ reduction only. The loading phase was not required since there was no PM accumulation or PM oxidation in the $\mathrm{SCRF}^{\circledR}$. When the emission samples of $\mathrm{NO}, \mathrm{NO}_{2}$, and $\mathrm{NH}_{3}$ stabilized, the $\mathrm{NO}_{\mathrm{x}}$ reduction stage was completed and the engine was shut down followed by saving the data.

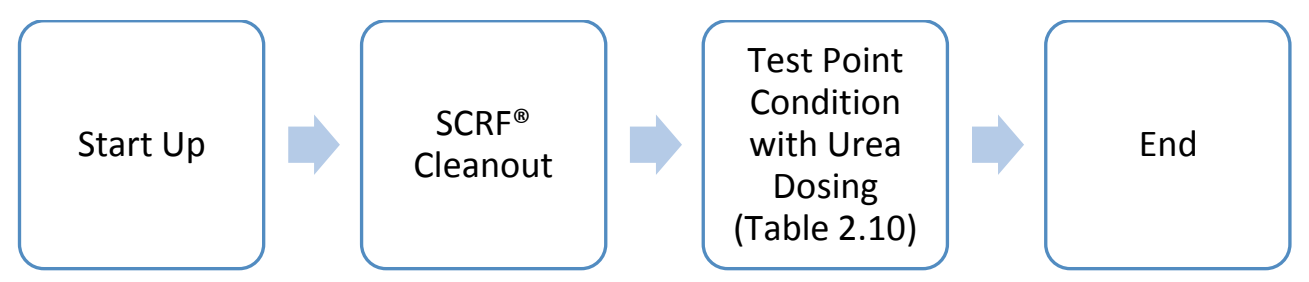

Figure 2.8 Schematic representation of the process of testing without PM loading in the SCRF ${ }^{\circledR}$ 


\section{Chapter 3. Results}

Chapter 2 discussed the experimental setup, test points and procedures used in this report. This chapter presents the findings of the research and discusses the significance of the data analysis. The analysis of the data from the engine and aftertreatment system configuration, is presented in terms of stage wise gaseous emissions and their conversion efficiency across the DOC and the $\mathrm{SCRF}^{\circledR}$.

A total of 12 runs were conducted in which loading constituted Stage-1, Stage-2 and repeated loading stages done in between the $\mathrm{NO}_{\mathrm{x}}$ reduction stage (with $\mathrm{PM}$ in the $\left.\mathrm{SCRF}^{\circledR}\right)$. Stage - 1 and Stage - 2 loading were carried out only for PM loaded SCRF ${ }^{\circledR}$ testing. The $\mathrm{SCRF}^{\circledR}$ was loaded to $2.0 \pm 0.2 \mathrm{~g} / \mathrm{L}$ and $4.0 \pm 0.4 \mathrm{~g} / \mathrm{L}$ before the $\mathrm{NO}_{\mathrm{x}}$ reduction stage. The notation $\mathrm{SCRF}^{\circledR}-0, \mathrm{SCRF}^{\circledR}-2$, and $\mathrm{SCRF}^{\circledR}-4$ represent $\mathrm{PM}$ loading of $0 \mathrm{~g} / \mathrm{L}, 2 \mathrm{~g} / \mathrm{L}$, and $4 \mathrm{~g} / \mathrm{L}$ in the $\mathrm{SCRF}^{\circledR}$ respectively.

From the results presented, $\mathrm{NO}_{\mathbf{x}}$ reductions efficiency and the amount of $\mathrm{NH}_{3}$ slip is determined and compared for loaded and unloaded $\mathrm{SCRF}^{\circledR}$ at different $\mathrm{ANR}$ values. Appendix C, E, and F discusses the stage wise PM balance, pressure drops, and temperature profiles respectively. The analyzed results obtained for $\mathrm{SCRF}^{\circledR}$ performance tests are then compared with the baseline SCR tests [6].

\section{1 $\mathrm{NO}_{\mathrm{x}}$ Reduction}

This section discusses the results of the $\mathrm{NO}_{\mathrm{x}}$ reduction test data at different test points. The test data for PM loading of 0,2 , and $4 \mathrm{~g} / \mathrm{L}$ in the $\mathrm{SCRF}^{\circledR}$ are analyzed and compared to determine the performance of the $\mathrm{SCRF}^{\circledR}$ at different loading conditions. The analysis is done with respect to different ammonia to $\mathrm{NO}_{\mathrm{x}}$ ratio values $(\mathrm{ANR}-0$, $0.8,1,1.2,1.2$ rpt.) at the inlet of the $\mathrm{SCRF}^{\circledR}$. The gaseous emissions for loading stages and $\mathrm{NO}_{\mathrm{x}}$ reduction stages (ANR - 0 and 1.2 rpt.) are presented in Appendix D.

\section{SCRF ${ }^{\circledR}$ Inlet Conditions}

The exhaust flows through the DOC, CPF or spacer, decomposition tube and the $\mathrm{SCRF}^{\circledR}$. The engine was run at a particular speed and load condition to achieve the desired $\mathrm{SCRF}^{\circledR}$ inlet temperatures and exhaust flow rates and in turn the space velocities. 
Space Velocity is defined as the number of volumes of the substrate per unit time processed by the substrate. The unit used in this study is $[\mathrm{k} / \mathrm{hr}]$. It is formulated as

$$
\text { Space Velocity }=\frac{\text { Mass Flow Rate } \text { exh }[\mathrm{kg} / \mathrm{hr}]}{\rho_{\text {exh }}\left[\mathrm{kg} / \mathrm{m}^{3}\right] * V_{\text {substrate }}\left[\mathrm{m}^{3}\right]} * \frac{1}{1000}
$$

(Equation 3.1)

Where, $\rho$ exh is the density of exhaust gas $\left[\mathrm{kg} / \mathrm{m}^{3}\right]$ and $\mathrm{V}_{\text {substrate }}$ is substrate volume

$$
\rho_{\text {exh }}=\frac{P}{R * T}
$$

Where, $\mathrm{P}$ is pressure at the inlet of $\mathrm{SCRF}^{\circledR}[\mathrm{kPa}], \mathrm{R}$ is the gas constant for exhaust $[0.287 \mathrm{~kJ} / \mathrm{kg} / \mathrm{K}]$, taken same as that of air, $\mathrm{T}$ is absolute temperature [K]. For standard space velocity calculations, the temperature and pressure are taken as 298 $\mathrm{K}$ and $101.32 \mathrm{kPa}$ respectively, and $\rho_{\text {exh,standard }}=1.29 \mathrm{~kg} / \mathrm{m}^{3}$.

Table 3.1 shows the inlet conditions of the $\mathrm{SCRF}^{\circledR}$ for the test points, selected from SCR baseline test matrix shown in Table 2.10. In Table 3.1, the SCRF $^{\circledR}$ inlet temperature is $207-218,302-305,340-347$, and $441-443{ }^{\circ} \mathrm{C}$ for test point $1,3,6$, and 8 respectively. The exhaust flow rate and space velocity were in the range of 5-17.7 $\mathrm{kg} / \mathrm{min}$. and $13.5-48.2 \mathrm{k} / \mathrm{hr}$ respectively where the lowest and highest values are for test point 1 and 8 respectively. Figure 3.1 shows the variation of inlet $\mathrm{SCRF}^{\circledR} \mathrm{NO}_{2}$ $/ \mathrm{NO}_{\mathrm{x}}$ ratio at different $\mathrm{SCRF}^{\circledR}$ inlet temperatures (test points). It is observed that the highest concentration of $\mathrm{NO}_{\mathrm{x}}$ into the $\mathrm{SCRF}^{\circledR}$ is for test point 6 with a highest $\mathrm{NO}_{2} / \mathrm{NO}_{\mathrm{x}}$ ratio of $0.43-0.46$.

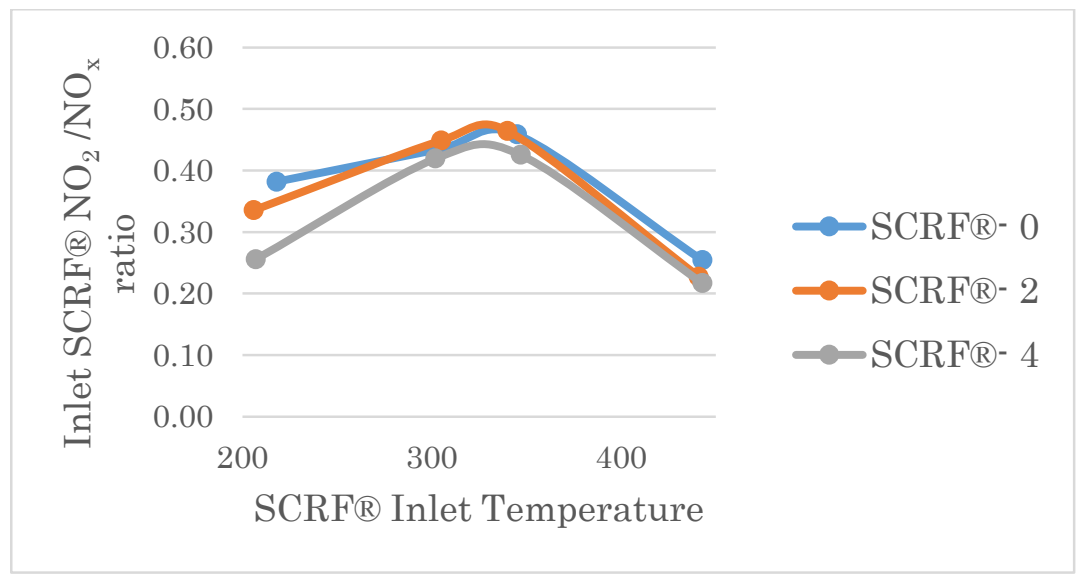

Figure 3.1 Inlet $\mathrm{SCRF}^{\circledR} \mathrm{NO}_{2} / \mathrm{NO}_{\mathrm{x}}$ ratio at different $\mathrm{SCRF}^{\circledR}$ inlet temperatures (test points) 
Table 3.1 Engine and $\mathrm{SCRF}^{\circledR}$ inlet conditions at different test points for $\mathrm{NO}_{\mathrm{x}}$ reduction test

\begin{tabular}{|c|c|c|c|c|c|}
\hline \multirow{2}{*}{ Parameter } & \multirow{2}{*}{ PM Loading } & \multicolumn{4}{|c|}{ Test Point } \\
\hline & & 1 & 3 & 6 & 8 \\
\hline \multirow{3}{*}{ Speed [RPM] } & $\mathrm{SCRF}^{\circledR}-0$ & 1199 & 2200 & 1202 & 2401 \\
\hline & $\mathrm{SCRF}^{\circledR}-2$ & 1200 & 2101 & 1200 & 2398 \\
\hline & $\mathrm{SCRF}^{\circledR}-4$ & 1200 & 2203 & 1200 & 2401 \\
\hline \multirow{3}{*}{$\begin{array}{l}\text { Load } \\
{[\mathrm{Nm}]}\end{array}$} & $\mathrm{SCRF}^{\circledR}-0$ & 201 & 330 & 580 & 826 \\
\hline & $\mathrm{SCRF}^{\circledR}-2$ & 208 & 329 & 588 & 820 \\
\hline & $\mathrm{SCRF}^{\circledR}-4$ & 203 & 331 & 587 & 818 \\
\hline \multirow{3}{*}{$\begin{array}{c}\text { Exhaust Flow } \\
{[\mathrm{kg} / \mathrm{min}]}\end{array}$} & $\mathrm{SCRF}^{\circledR}-0$ & 5.0 & 10.7 & 6.9 & 17.0 \\
\hline & $\mathrm{SCRF}^{\circledR}-2$ & 5.0 & 9.9 & 6.8 & 17.6 \\
\hline & $\mathrm{SCRF}^{\circledR}-4$ & 5.0 & 10.9 & 6.8 & 17.7 \\
\hline \multirow{3}{*}{$\begin{array}{c}\text { SCRF }^{\circledR} \text { Inlet } \\
\text { Temperature } \\
{\left[{ }^{\circ} \mathrm{C}\right]}\end{array}$} & $\mathrm{SCRF}^{\circledR-} 0$ & 218 & 304 & 345 & 443 \\
\hline & SCRF $^{\circledR}-2$ & 206 & 305 & 340 & 441 \\
\hline & $\mathrm{SCRF}^{\circledR}-4$ & 207 & 302 & 347 & 443 \\
\hline \multirow{3}{*}{$\begin{array}{c}\text { SCRF }^{\circledR} \text { Std. } \\
\text { Space Vel. }[\mathrm{k} / \mathrm{hr}]\end{array}$} & $\mathrm{SCRF}^{\circledR-} 0$ & 13.7 & 29.1 & 18.8 & 46.3 \\
\hline & $\mathrm{SCRF}^{\circledR}-2$ & 13.7 & 27.0 & 18.6 & 48.0 \\
\hline & $\mathrm{SCRF}^{\circledR}-4$ & 13.5 & 29.8 & 18.6 & 48.2 \\
\hline \multirow{3}{*}{$\begin{array}{c}\text { SCRF }^{\circledR} \text { Act. } \\
\text { Space Vel. }[\mathrm{k} / \mathrm{hr}]\end{array}$} & SCRF $^{\circledR}-0$ & 24.5 & 60.2 & 42.0 & 115 \\
\hline & $\mathrm{SCRF}^{\circledR}-2$ & 22.6 & 53.8 & 39.3 & 118 \\
\hline & $\mathrm{SCRF}^{\circledR}-4$ & 22.7 & 56.4 & 39.9 & 108 \\
\hline \multirow{3}{*}{$\begin{array}{c}\text { SCRF }^{\circledR} \text { Inlet NO } \\
\text { [ppm] }\end{array}$} & SCRF $^{\circledR}-0$ & 345 & 158 & 795 & 411 \\
\hline & $\mathrm{SCRF}^{\circledR}-2$ & 403 & 161 & 743 & 424 \\
\hline & $\mathrm{SCRF}^{\circledR}-4$ & 453 & 198 & 793 & 415 \\
\hline \multirow{3}{*}{$\begin{array}{l}\mathrm{SCRF}^{\circledR} \text { Inlet } \\
\mathrm{NO}_{2} \text { [ppm] }\end{array}$} & $\mathrm{SCRF}^{\circledR}-0$ & 213 & 121 & 674 & 140 \\
\hline & $\mathrm{SCRF}^{\circledR}-2$ & 203 & 131 & 644 & 125 \\
\hline & $\mathrm{SCRF}^{\circledR}-4$ & 146 & 124 & 588 & 115 \\
\hline \multirow{3}{*}{$\begin{array}{c}\mathrm{SCRF}^{\circledR} \\
\text { Inlet } \mathrm{NO}_{\mathrm{x}} \\
\text { [ppm] }\end{array}$} & $\mathrm{SCRF}^{\circledR}-0$ & 558 & 279 & 1468 & 551 \\
\hline & $\mathrm{SCRF}^{\circledR}-2$ & 607 & 292 & 1387 & 548 \\
\hline & $\mathrm{SCRF}^{\circledR}-4$ & 599 & 322 & 1381 & 530 \\
\hline \multirow{3}{*}{$\begin{array}{l}\text { Upstream } \\
\mathrm{NO}_{2} / \mathrm{NO}_{\mathrm{x}}\end{array}$} & $\mathrm{SCRF}^{\circledR}-0$ & 0.38 & 0.43 & 0.46 & 0.25 \\
\hline & $\mathrm{SCRF}^{\circledR}-2$ & 0.34 & 0.45 & 0.46 & 0.23 \\
\hline & $\mathrm{SCRF}^{\circledR}-4$ & $0.24^{1}$ & 0.39 & 0.43 & 0.22 \\
\hline \multirow{3}{*}{$\begin{array}{l}\text { Engine Out PM } \\
{[\mathrm{mg} / \mathrm{scm}]^{3}}\end{array}$} & $\mathrm{SCRF}^{\circledR}-0$ & N/A & N/A & N/A & N/A \\
\hline & $\mathrm{SCRF}^{\circledR}-2$ & 2.14 & 4.30 & 3.59 & 7.39 \\
\hline & $\mathrm{SCRF}^{\circledR}-4$ & 1.97 & 4.93 & 2.85 & $4.97^{2}$ \\
\hline
\end{tabular}

${ }^{1} \mathrm{NO}_{2} / \mathrm{NO}_{\mathrm{x}}$ ratio is inconsistent with other $\mathrm{SCRF}^{\circledR}-0$ and 2 loading tests because of inaccurate reading of $\mathrm{NO}$ and $\mathrm{NO}_{\mathrm{x}}$ species concentration from mass spectrometer

2 The engine out PM is lower than expected because the filter papers had moisture prior to PM collection ${ }^{3} \mathrm{scm}$ is a volume of the exhaust (cubic meter) sampled which is converted to standard conditions of $298 \mathrm{~K}$ and $101.32 \mathrm{kPa}$ 


\section{NO Conversion across DOC}

The NO conversion across the DOC determines the species concentration of NO and $\mathrm{NO}_{2}$ at the outlet of the $\mathrm{SCRF}^{\circledR}$. The conversion depends on the inlet temperature and space velocity of the exhaust flowing through the DOC.

The species conversion efficiencies are calculated from inlet and outlet species concentrations as given by Equation 3.2

$$
\begin{aligned}
& \text { DOC or } S C R F \circledR\left(N O / N O_{x}\right) \text { Conversion efficiency (\%) } \\
& =\frac{\operatorname{Inlet}\left(N O / N O_{x}\right)-\text { Outlet }\left(N O / N O_{x}\right)}{\text { Inlet }\left(N O / N O_{x}\right)} * 100
\end{aligned}
$$

(Equation 3.2)

Table 3.2 gives the $\mathrm{NO}$ and $\mathrm{NO}_{2}$ species concentration at upstream and downstream location of the DOC. The concentrations of $\mathrm{NO}$ and $\mathrm{NO}_{2}$ are in agreement for individual test points at 0,2 , and $4 \mathrm{~g} / \mathrm{L}$ loading since the $\mathrm{PM}$ loading in the $\mathrm{SCRF}^{\circledR}$ is not related with the DOC performance.

Table 3.3 gives the DOC inlet temperature, DOC space velocity and DOC NO conversion efficiency. It was observed that the NO conversion efficiency was higher in temperature range of $300-350{ }^{\circ} \mathrm{C}$ (test point 3 and 6) and decreased as temperature approached $440{ }^{\circ} \mathrm{C}$ (test point 8). The trend for NO conversion efficiency is discussed in Reference [7] where the maxima lies close to $325^{\circ} \mathrm{C}$ and decreases at temperatures higher or lower than $325^{\circ} \mathrm{C}$.

\begin{tabular}{|c|c|c|c|c|c|c|c|c|c|c|c|c|}
\hline \multirow{3}{*}{$\begin{array}{l}\text { Test } \\
\text { Point }\end{array}$} & \multicolumn{6}{|c|}{ NO } & \multicolumn{6}{|c|}{$\mathrm{NO}_{2}$} \\
\hline & \multicolumn{2}{|c|}{$\mathrm{SCRF}^{\circledR}-0$} & \multicolumn{2}{|c|}{ SCRF $^{\circledR}-2$} & \multicolumn{2}{|c|}{$\mathrm{SCRF}^{\circledR}-4$} & \multicolumn{2}{|c|}{$\mathrm{SCRF}^{\circledR}-0$} & \multicolumn{2}{|c|}{ SCRF $^{\circledR ~-~} 2$} & \multicolumn{2}{|c|}{$\mathrm{SCRF}^{\circledR}-4$} \\
\hline & In & Out & In & Out & In & Out & In & Out & In & Out & In & Out \\
\hline$[-]$ & [ppm] & [ppm] & [ppm] & [ppm] & [ppm] & [ppm] & [ppm] & [ppm] & [ppm] & [ppm] & [ppm] & [ppm] \\
\hline 1 & 575 & 345 & 581 & 403 & 563 & 453 & 5 & 213 & 2 & 203 & 37 & 146 \\
\hline 3 & 257 & 160 & 288 & 161 & 324 & 198 & 18 & 120 & 0 & 131 & 1 & 124 \\
\hline 6 & 1336 & 795 & 1484 & 743 & 1483 & 793 & 18 & 674 & 4 & 644 & 14 & 588 \\
\hline 8 & 542 & 411 & 556 & 424 & 507 & 415 & 1 & 140 & 2 & 125 & 8 & 115 \\
\hline
\end{tabular}

Table 3.2 NO and $\mathrm{NO}_{2}$ species concentration at the inlet and outlet DOC for different test points 
Table 3.3 DOC inlet temperature, space velocity and NO conversion efficiency for different test points

\begin{tabular}{|c|c|c|c|c|c|c|c|c|c|}
\hline \multirow{2}{*}{$\begin{array}{l}\text { Test } \\
\text { Point }\end{array}$} & \multicolumn{3}{|c|}{ DOC Inlet Temp. $\left[{ }^{\circ} \mathrm{C}\right]$} & \multicolumn{3}{|c|}{$\begin{array}{c}\text { SCRF }^{\circledR} \text { Space Velocity } \\
{[\mathrm{k} / \mathrm{hr}]}\end{array}$} & \multicolumn{3}{|c|}{ NO Conv. \% across DOC } \\
\hline & $\begin{array}{c}\text { SCRF } \\
\circledast-0\end{array}$ & $\begin{array}{l}\text { SCRF } \\
\circledR-2\end{array}$ & $\begin{array}{c}\text { SCRF } \\
\circledast-4\end{array}$ & $\begin{array}{c}\text { SCRF } \\
\circledast-0\end{array}$ & $\begin{array}{l}\text { SCRF } \\
\circledast-2\end{array}$ & $\begin{array}{c}\text { SCRF } \\
\circledast-4\end{array}$ & $\begin{array}{l}\text { SCRF } \\
\circledast-0\end{array}$ & $\begin{array}{c}\text { SCRF } \\
\circledast-2\end{array}$ & $\begin{array}{c}\text { SCRF } \\
\circledast-4\end{array}$ \\
\hline 1 & 221 & 218 & 214 & 55.7 & 56.1 & 55.2 & 40 & 31 & 20 \\
\hline 3 & 306 & 315 & 316 & 119.1 & 110.4 & 121.7 & 38 & 44 & 39 \\
\hline 6 & 346 & 355 & 362 & 76.8 & 76.1 & 75.9 & 40 & 50 & 46 \\
\hline 8 & 439 & 442 & 449 & 189.3 & 196.3 & 196.9 & 24 & 24 & 18 \\
\hline
\end{tabular}

\section{$\mathrm{NO}_{2}$ Decrease and $\mathrm{NO}_{\mathrm{x}}$ Conversion across $\mathrm{SCRF}^{\circledR}$}

The concentrations of both $\mathrm{NO}$ and $\mathrm{NO}_{2}$ decrease across the $\mathrm{SCRF}^{\circledR}$ when dosed with urea due to the reduction reaction of $\mathrm{NO}$ and $\mathrm{NO}_{2}$ with ammonia to form nitrogen. The effects of ANR on the $\mathrm{NO}_{\mathrm{x}}$ conversion efficiency is discussed in this section.

Figure 3.2 shows the trend of $\mathrm{NO}_{2} / \mathrm{NO}_{\mathrm{x}}$ ratio at inlet or outlet of the $\mathrm{SCRF}^{\circledR}$ with $\mathrm{SCRF}^{\circledR}$ inlet temperatures and loading, without urea dosing. This can be explained by increased participation of $\mathrm{NO}_{2}$ in $\mathrm{PM}$ oxidation at high temperature with $\mathrm{PM}$ in the filter [2].

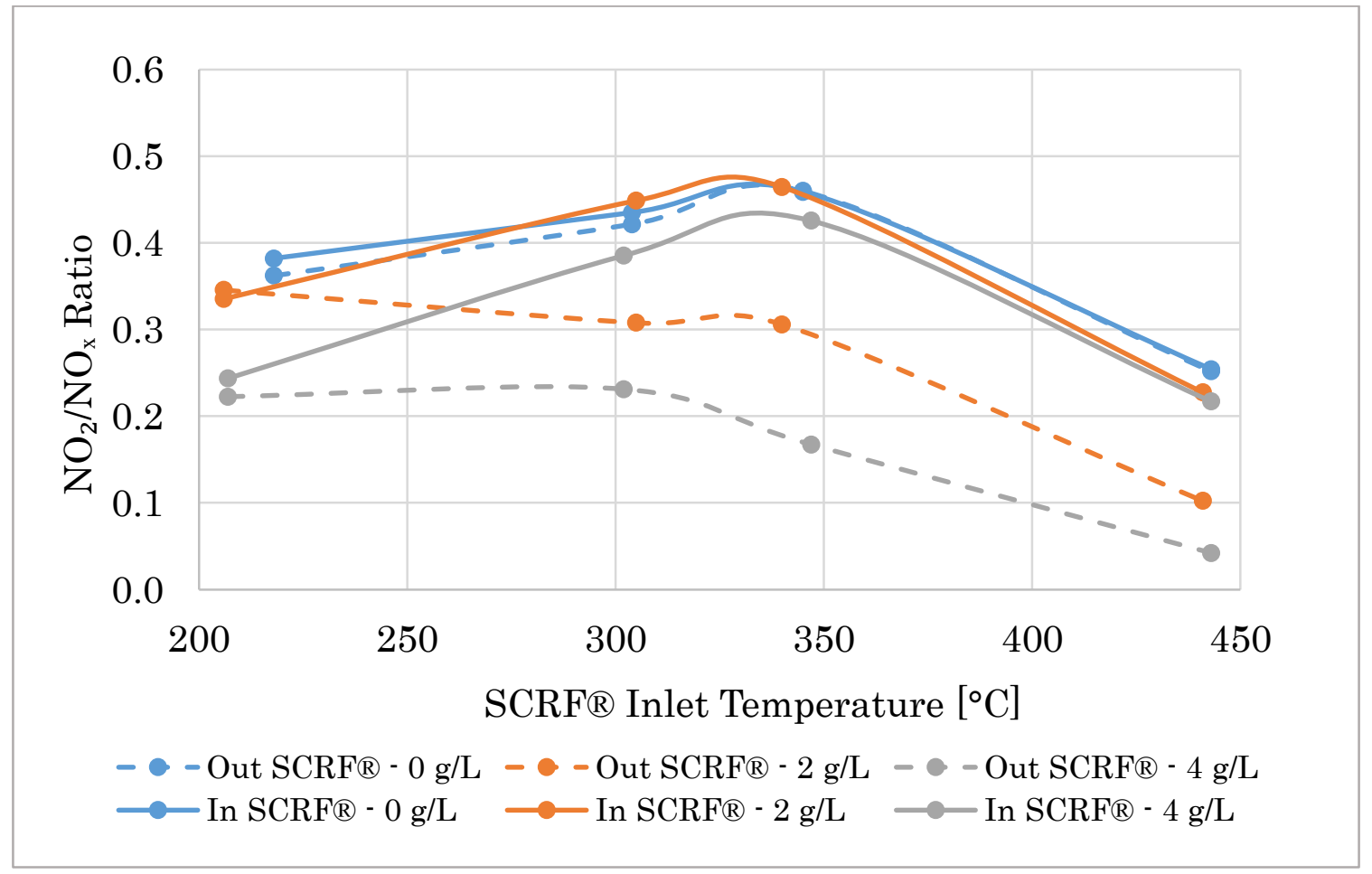

Figure 3.2 Change in $\mathrm{NO}_{2} / \mathrm{NO}_{\mathrm{x}}$ ratio at inlet and outlet of the $\mathrm{SCRF}^{\circledR}$ with different $\mathrm{SCRF}^{\circledR}$ inlet temperatures for 0,2 , and $4 \mathrm{~g} / \mathrm{L}$ loading $\mathrm{ANR}-0$ 
Tables 3.4, 3.6, and 3.8 show the $\mathrm{NO}$ and $\mathrm{NO}_{2}$ concentrations at the inlet and outlet of the $\mathrm{SCRF}^{\circledR}$ (loaded with 0,2 , and $4 \mathrm{~g} / \mathrm{L}$ ) at $\mathrm{ANR}-0.8,1$, and 1.2 respectively. It is observed from these tables that, with urea dosing, the $\mathrm{NO}_{2}$ concentration decreases with PM loading for all test points. Also, the NO concentration downstream of the $\mathrm{SCRF}^{\circledR}$ is affected by the conversion of $\mathrm{NO}_{2}$ to $\mathrm{NO}$ during $\mathrm{NO}_{2}$ assisted PM oxidation. At $\mathrm{ANR}-1$ and 1.2 , the $\mathrm{NO}_{2}$ concentration downstream of the $\mathrm{SCRF}^{\circledR}$ is negligible.

The $\mathrm{NO}_{\mathrm{x}}$ conversion efficiency data for the test points at different $\mathrm{ANR}$ values are shown in Tables 3.7 and 3.9. Figures 3.3, 3.4, and 3.5 show the $\mathrm{NO}_{\mathrm{x}}$ conversion efficiency plots of $\mathrm{SCRF}^{\circledR}$ as a function of $\mathrm{SCRF}^{\circledR}$ inlet temperatures when loaded with 0,2 , and $4 \mathrm{~g} / \mathrm{L}$ for $\mathrm{ANR}-0.8,1,1.2$ respectively. The factors affecting $\mathrm{NO}_{\mathrm{x}}$ conversion efficiency are $\mathrm{SCRF}^{\circledR}$ inlet temperature, $\mathrm{PM}$ loading $(0,2$, and $4 \mathrm{~g} / \mathrm{L})$ in $\mathrm{SCRF}^{\circledR}$, and $\mathrm{NO}_{2} / \mathrm{NO}_{\mathrm{x}}$ at inlet to the $\mathrm{SCRF}^{\circledR}$. Figure 3.4 shows the highest $\mathrm{NO}_{\mathrm{x}}$ conversion efficiency of $99 \%$ for test point 6 without PM loading at ANR - 1. Figure 3.5 shows nearly constant $\mathrm{NO}_{\mathrm{x}}$ conversion efficiency for test points 1,3 , and 6 .

In Figures 3.3, 3.4, and 3.5, there is a slight decrease in the $\mathrm{NO}_{\mathrm{x}}$ conversion efficiency for test points 6 and 8 with loading. The major portion of the $\mathrm{NO}_{\mathrm{x}}$ concentration comprises $\mathrm{NO}$ since the $\mathrm{NO}_{2}$ concentration at the downstream $\mathrm{SCRF}^{\circledR}$, for $\mathrm{ANR}-0.8$, 1 and 1.2, is negligible. There is high $\mathrm{NO}_{2}$ to $\mathrm{NO}$ conversion for loaded $\mathrm{SCRF}^{\circledR}$.

In Table 3.5, the $\mathrm{NO}_{\mathrm{x}}$ conversion efficiency for $\mathrm{SCRF}^{\circledR}$ loaded at $4 \mathrm{~g} / \mathrm{L}$ compared to 0 $\mathrm{g} / \mathrm{L}$ is $4 \%$ higher for test point 3 and is $7 \%$ lower for test point 8 . The decrement in $\mathrm{NO}_{\mathrm{x}}$ conversion efficiency for $4 \mathrm{~g} / \mathrm{L}$ loading compared to $0 \mathrm{~g} / \mathrm{L}$ will be less than $7 \%$ since the actual ANR dosed was lower than 0.8. For test point $6, \mathrm{SCRF}^{\circledR}$ loaded with $0 \mathrm{~g} / \mathrm{L}$, the actual ANR was 0.77 and therefore gives lower $\mathrm{NO}_{\mathrm{x}}$ conversion efficiency of $83 \%$. It is observed that the $\mathrm{NO}_{\mathrm{x}}$ reduction efficiency improved with loading until the temperature around $300{ }^{\circ} \mathrm{C}$ and then decreased for temperatures above $350{ }^{\circ} \mathrm{C}$. 
Table 3.4 Species concentration at upstream and downstream $\mathrm{SCRF}^{\circledR}$ for $\mathrm{NO}_{\mathrm{x}}$ reduction test points at $\mathrm{ANR}-0.8$

\begin{tabular}{|c|c|c|c|c|c|c|c|c|c|c|c|c|c|c|c|c|c|c|}
\hline \multirow{3}{*}{$\begin{array}{l}\text { Test } \\
\text { Point }\end{array}$} & \multicolumn{6}{|c|}{ NO [ppm] } & \multicolumn{6}{|c|}{$\mathrm{NO}_{2}$ [ppm] } & \multicolumn{6}{|c|}{$\mathrm{NH}_{3}$ [ppm] } \\
\hline & \multicolumn{2}{|c|}{$\mathrm{SCRF}^{\circledR-} 0$} & \multicolumn{2}{|c|}{$\mathrm{SCRF}^{\circledR-} 2$} & \multicolumn{2}{|c|}{$\mathrm{SCRF}^{\circledR-} 4$} & \multicolumn{2}{|c|}{$\mathrm{SCRF}^{\circledR-} 0$} & \multicolumn{2}{|c|}{$\mathrm{SCRF}^{\circledR}-2$} & \multicolumn{2}{|c|}{ SCRF ${ }^{\circledR}-4$} & \multicolumn{2}{|c|}{$\mathrm{SCRF}^{\circledR-} 0$} & \multicolumn{2}{|c|}{$\mathrm{SCRF}^{\circledR-2}$} & \multicolumn{2}{|c|}{ SCRF $^{\circledR-~} 4$} \\
\hline & In & Out & In & Out & In & Out & In & Out & In & Out & In & Out & In & Out & In & Out & In & Out \\
\hline 1 & 345 & 136 & 403 & 142 & 453 & 124 & 213 & 6 & 203 & 1 & 146 & 1 & 446 & 1 & 486 & 2 & 481 & 2 \\
\hline 3 & 158 & 44 & 161 & 63 & 198 & 55 & 121 & 18 & 131 & 2 & 124 & 1 & 220 & 2 & 231 & 1 & 274 & 0 \\
\hline 6 & 795 & 108 & 743 & 273 & 793 & 275 & 674 & 149 & 644 & 10 & 588 & 7 & 1125 & 0 & 1096 & 0 & 1093 & 2 \\
\hline 8 & 411 & 99 & 424 & 117 & 415 & 147 & 140 & 6 & 125 & 1 & 115 & 1 & 438 & 12 & 426 & 7 & 399 & 27 \\
\hline
\end{tabular}

Table 3.5 Species conversion efficiency across $\mathrm{SCRF}^{\circledR}$ for $\mathrm{NO}_{\mathrm{x}}$ reduction test points at ANR-0.8

\begin{tabular}{|c|c|c|c|c|c|c|c|c|c|}
\hline \multirow{2}{*}{ Test Point } & \multicolumn{3}{|c|}{ ANR } & \multicolumn{3}{|c|}{$\mathrm{NO}_{\mathrm{x}}$ conversion efficiency [\%] } & \multicolumn{3}{|c|}{ Nitrogen Balance [\%] } \\
\hline & SCRF $^{\circledR-} 0$ & SCRF $^{\circledR-2}$ & $\mathrm{SCRF}^{\circledR-} 4$ & SCRF $^{\circledR-0}$ & SCRF $^{\circledR-2}$ & SCRF $^{\circledR-4}$ & SCRF $^{\circledR-} 0$ & SCRF $^{\circledR-2}$ & $\mathrm{SCRF}^{\circledR-} 4$ \\
\hline 1 & 0.80 & 0.80 & 0.80 & 75 & 77 & 79 & 94 & 96 & 89 \\
\hline 3 & 0.79 & 0.79 & 0.85 & 78 & 78 & 82 & 99 & 99 & 97 \\
\hline 6 & 0.77 & 0.79 & 0.79 & 83 & 80 & 80 & 108 & 101 & 101 \\
\hline 8 & 0.79 & 0.78 & 0.75 & 81 & 78 & 72 & 105 & 103 & 102 \\
\hline
\end{tabular}

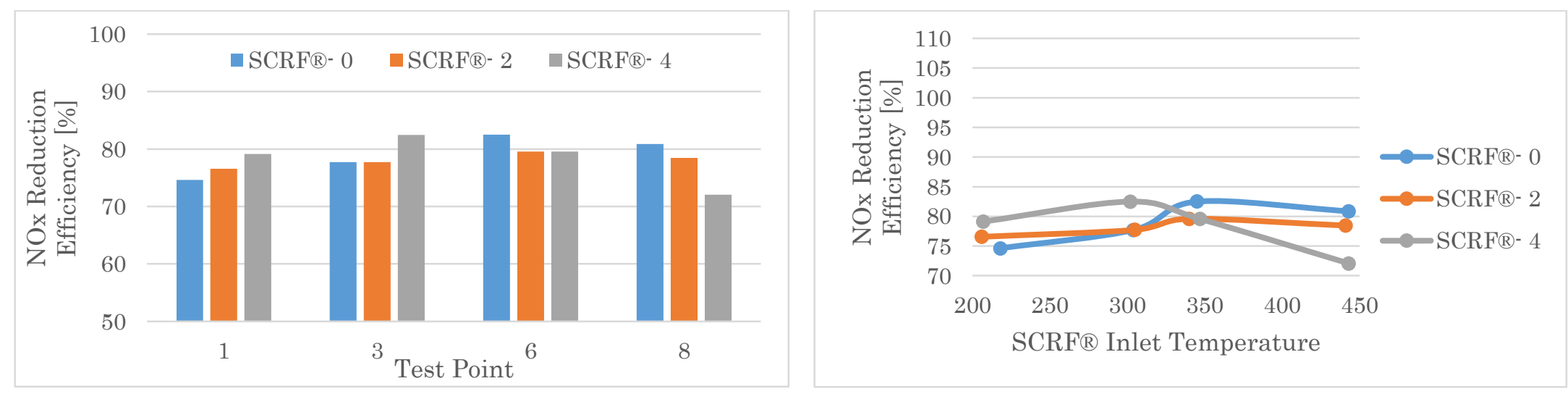

Figure 3.3 Variation of $\mathrm{NO}_{\mathrm{x}}$ conversion efficiency (\%) with $\mathrm{ANR}-0.8$ for $\mathrm{NO}_{\mathrm{x}}$ reduction test points and $\mathrm{SCRF}^{\circledR}$ inlet temperatures 
In Figure 3.4, the $\mathrm{NO}_{\mathrm{x}}$ conversion efficiency trend for ANR - 1 is similar to the one for ANR 0.8 shown in Figure 3.3. For test point 3, $\mathrm{SCRF}^{\circledR}$ loaded with $4 \mathrm{~g} / \mathrm{L}$, the $\mathrm{NO}_{\mathrm{x}}$ conversion efficiency came out lower i.e. 98\% as the actual ANR value was 1.03 at the time of testing. The $\mathrm{NO}_{\mathrm{x}}$ conversion efficiency reached $98 \%$ and $99 \%$ for test point 3 with PM loading of $4 \mathrm{~g} / \mathrm{L}$ and test point 6 with PM loading of $0 \mathrm{~g} / \mathrm{L}$ respectively, which are the maxima of their curves in Figure 3.4.

Table 3.9 shows that the $\mathrm{NO}_{\mathrm{x}}$ conversion efficiency is above $97 \%$ for all test points except test point 8. As shown in Table 3.1, the $\mathrm{SCRF}^{\circledR}$ inlet temperature (around $440{ }^{\circ} \mathrm{C}$ ) and space velocity (around $48 \mathrm{k} / \mathrm{hr}$ ) are higher for test point 8 compared to other test points (1, 3, and 6). Above $400{ }^{\circ} \mathrm{C}$, the oxidation of $\mathrm{NH}_{3}$ to $\mathrm{N}_{2}$ and $\mathrm{NO}$ becomes dominant and therefore $\mathrm{NO}_{\mathrm{x}}$ conversion efficiency is poor [1]. 
Table 3.6 Species concentration at upstream and downstream $\mathrm{SCRF}^{\circledR}$ for $\mathrm{NO}_{\mathrm{x}}$ reduction test points at ANR-1

\begin{tabular}{|c|c|c|c|c|c|c|c|c|c|c|c|c|c|c|c|c|c|c|}
\hline \multirow{3}{*}{$\begin{array}{l}\text { Test } \\
\text { Point }\end{array}$} & \multicolumn{6}{|c|}{ NO [ppm] } & \multicolumn{6}{|c|}{$\mathrm{NO}_{2}$ [ppm] } & \multicolumn{6}{|c|}{$\mathrm{NH}_{3}$ [ppm] } \\
\hline & \multicolumn{2}{|c|}{ SCRF $^{\circledR-} 0$} & \multicolumn{2}{|c|}{ SCRF $^{\circledR-2}$} & \multicolumn{2}{|c|}{ SCRF $^{\circledR}-4$} & \multicolumn{2}{|c|}{ SCRF $^{\circledR-} 0$} & \multicolumn{2}{|c|}{$\mathrm{SCRF}^{\circledR-} 2$} & \multicolumn{2}{|c|}{ SCRF $^{\circledR-~} 4$} & \multicolumn{2}{|c|}{ SCRF $^{\circledR-~} 0$} & \multicolumn{2}{|c|}{ SCRF 2} & \multicolumn{2}{|c|}{$\mathrm{SCRF}^{\circledR-} 4$} \\
\hline & In & Out & In & Out & In & Out & In & Out & In & Out & In & Out & In & Out & In & Out & In & Out \\
\hline 1 & 345 & 61 & 403 & 49 & 453 & 47 & 213 & 0 & 203 & 0 & 146 & 0 & 558 & 2 & 609 & 3 & 600 & 5 \\
\hline 3 & 158 & 11 & 161 & 13 & 198 & 8 & 121 & 1 & 131 & 0 & 124 & 0 & 275 & 5 & 289 & 1 & 331 & 4 \\
\hline 6 & 795 & 6 & 743 & 60 & 793 & 85 & 674 & 3 & 644 & 1 & 588 & 2 & 1404 & 7 & 1370 & 1 & 1360 & 9 \\
\hline 8 & 411 & 43 & 424 & 61 & 415 & 60 & 140 & 3 & 125 & 0 & 115 & 0 & 548 & 35 & 536 & 16 & 522 & 55 \\
\hline
\end{tabular}

Table 3.7 Species conversion efficiency across $\mathrm{SCRF}^{\circledR}$ for $\mathrm{NO}_{\mathrm{x}}$ reduction test points at ANR-1

\begin{tabular}{|c|c|c|c|c|c|c|c|c|c|}
\hline \multirow{2}{*}{ Test Point } & \multicolumn{3}{|c|}{ ANR } & \multicolumn{3}{|c|}{$\mathrm{NO}_{\mathrm{x}}$ conversion efficiency [\%] } & \multicolumn{3}{|c|}{ Nitrogen Balance [\%] } \\
\hline & SCRF $^{\circledR-0}$ & SCRF $^{\circledR-2}$ & $\mathrm{SCRF}^{\circledR-4}$ & SCRF $^{\circledR-0} 0$ & SCRF $^{\circledR-2}$ & SCRF $^{\circledR-~} 4$ & SCRF $^{\circledR-0}$ & SCRF $^{\circledR-2}$ & $\mathrm{SCRF}^{\circledR-} 4$ \\
\hline 1 & 1.00 & 1.00 & 1.00 & 89 & 92 & 92 & 89 & 92 & 93 \\
\hline 3 & 0.99 & 0.99 & 1.03 & 96 & 96 & 98 & 99 & 97 & 96 \\
\hline 6 & 0.96 & 0.99 & 0.98 & 99 & 96 & 94 & 104 & 97 & 96 \\
\hline 8 & 0.99 & 0.98 & 0.98 & 92 & 89 & 89 & 99 & 94 & 101 \\
\hline
\end{tabular}
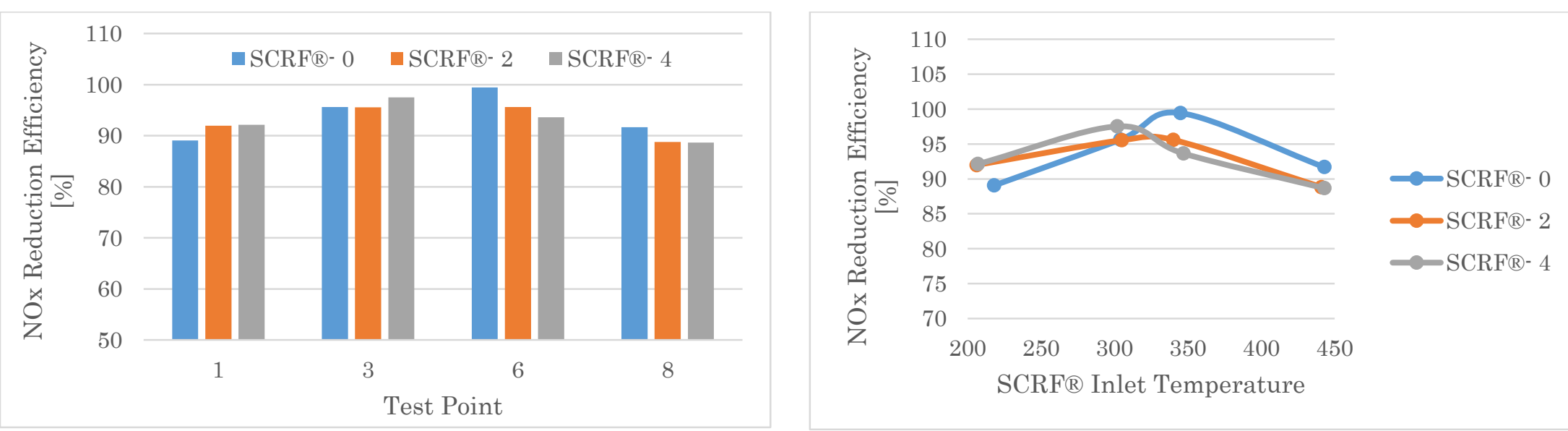

Figure 3.4 Variation of $\mathrm{NO}_{\mathrm{x}}$ conversion efficiency (\%) with $\mathrm{ANR}-1$ for $\mathrm{NO}_{\mathrm{x}}$ reduction test points and $\mathrm{SCRF}{ }^{\circledR}$ inlet temperatures 
Table 3.8 Species concentration at upstream and downstream $\mathrm{SCRF}^{\circledR}$ for $\mathrm{NO}_{\mathrm{x}}$ reduction test points at $\mathrm{ANR}-1.2$

\begin{tabular}{|c|c|c|c|c|c|c|c|c|c|c|c|c|c|c|c|c|c|c|}
\hline \multirow{3}{*}{$\begin{array}{l}\text { Test } \\
\text { Point }\end{array}$} & \multicolumn{6}{|c|}{ NO [ppm] } & \multicolumn{6}{|c|}{$\mathrm{NO}_{2}[\mathrm{ppm}]$} & \multicolumn{6}{|c|}{$\mathrm{NH}_{3}[\mathrm{ppm}]$} \\
\hline & \multicolumn{2}{|c|}{ SCRF- 0} & \multicolumn{2}{|c|}{ SCRF $^{\circledR-2}$} & \multicolumn{2}{|c|}{$\mathrm{SCRF}^{\circledR-4}$} & \multicolumn{2}{|c|}{ SCRF $^{\circledR}-0$} & \multicolumn{2}{|c|}{$\mathrm{SCRF}^{\circledR}-2$} & \multicolumn{2}{|c|}{ SCRF $^{\circledR-} 4$} & \multicolumn{2}{|c|}{$\mathrm{SCRF}^{\circledR-} 0$} & \multicolumn{2}{|c|}{ SCRF $^{\circledR-2}$} & \multicolumn{2}{|c|}{$\mathrm{SCRF}^{\circledR-4}$} \\
\hline & In & Out & In & Out & In & Out & In & Out & In & Out & In & Out & In & Out & In & Out & In & Out \\
\hline 1 & 345 & 7 & 403 & 7 & 453 & 15 & 213 & 0 & 203 & 0 & 146 & 0 & 669 & 112 & 730 & 141 & 722 & 185 \\
\hline 3 & 158 & 4 & 161 & 2 & 198 & 3 & 121 & 1 & 131 & 0 & 124 & 0 & 331 & 60 & 347 & 50 & 398 & 68 \\
\hline 6 & 795 & 2 & 743 & 6 & 793 & 14 & 674 & -1 & 644 & 0 & 588 & 2 & 1685 & 197 & 1644 & 107 & 1633 & 106 \\
\hline 8 & 411 & 36 & 424 & 46 & 415 & 52 & 140 & 2 & 125 & 0 & 115 & 0 & 657 & 84 & 640 & 36 & 626 & 79 \\
\hline
\end{tabular}

Table 3.9 Species conversion efficiency across $\mathrm{SCRF}^{\circledR}$ for $\mathrm{NO}_{\mathrm{x}}$ reduction test points at ANR-1.2

\begin{tabular}{|c|c|c|c|c|c|c|c|c|c|}
\hline \multirow{2}{*}{ Test Point } & \multicolumn{3}{|c|}{ ANR } & \multicolumn{3}{|c|}{$\mathrm{NO}_{\mathrm{x}}$ conversion efficiency $[\%]$} & \multicolumn{3}{|c|}{ Nitrogen Balance [\%] } \\
\hline & SCRF $^{\circledR-0}$ & SCRF $^{\circledR-} 2$ & SCRF $^{\circledR-~} 4$ & SCRF $^{\circledR-} 0$ & SCRF $^{\circledR-2}$ & SCRF $^{\circledR-~} 4$ & SCRF $^{\circledR}-0$ & SCRF $^{\circledR-2}$ & $\mathrm{SCRF}^{\circledR-} 4$ \\
\hline 1 & 1.20 & 1.20 & 1.21 & 99 & 99 & 98 & 99 & 101 & 107 \\
\hline 3 & 1.19 & 1.19 & 1.24 & 98 & 99 & 99 & 101 & 98 & 97 \\
\hline 6 & 1.15 & 1.19 & 1.18 & 100 & 100 & 99 & 99 & 91 & 90 \\
\hline 8 & 1.19 & 1.17 & 1.18 & 93 & 92 & 90 & 91 & 84 & 89 \\
\hline
\end{tabular}

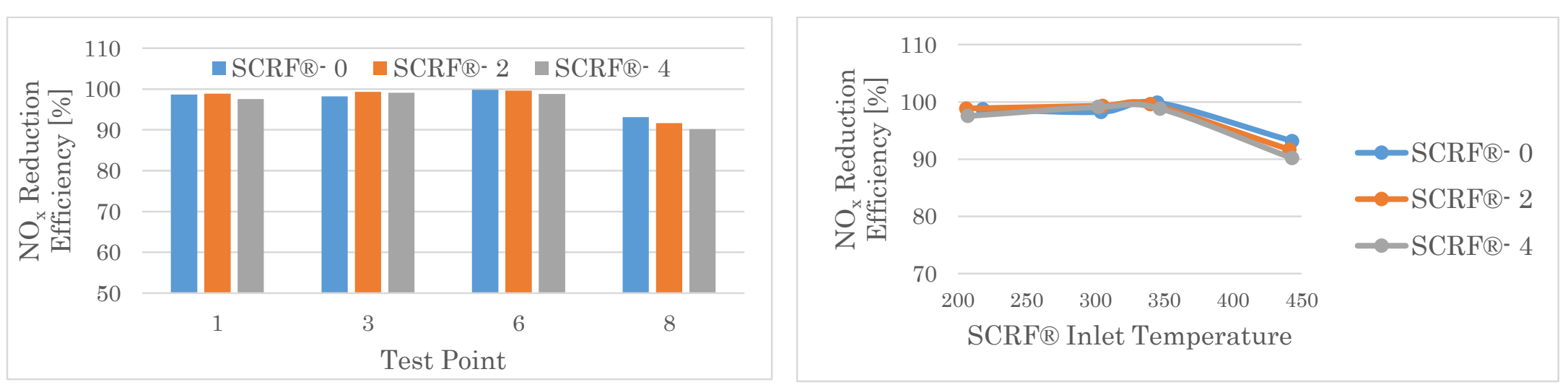

Figure 3.5 Variation of $\mathrm{NO}_{\mathrm{x}}$ conversion efficiency (\%) with $\mathrm{ANR}-1.2$ for $\mathrm{NO}_{\mathrm{x}}$ reduction test point 


\section{2 $\mathrm{NH}_{3}$ Slip and Nitrogen Balance}

The $\mathrm{NH}_{3}$ inlet and outlet concentrations across the $\mathrm{SCRF}^{\circledR}$ are shown in Tables 3.4, 3.6, and 3.8. The urea (32.5\% concentration in urea-water solution) injected in the decomposition tube decomposes to ammonia $\left(\mathrm{NH}_{3}\right)$ and reduces the exhaust $\mathrm{NO}_{\mathrm{x}}$ across the $\mathrm{SCRF}^{\circledR}$. The $\mathrm{NH}_{3}$ entering the $\mathrm{SCRF}^{\circledR}$, if all the urea is converted to $\mathrm{NH}_{3}$, can be calculated from the values of urea injection rate and the known properties of urea and the exhaust. The $\mathrm{NH}_{3}$ inlet to $\mathrm{SCRF}^{\circledR}$ is formulated as:

$$
\begin{aligned}
S C R F \circledast \text { Inlet } & \mathrm{NH}_{3}(\mathrm{ppm}) \\
& =\frac{\text { Urea injection rate } * 0.325 * M W \text { of Exhaust gas } * \text { Urea Density }}{\text { Exhaust Flow rate } * M W \text { of Urea }}
\end{aligned}
$$

(Equation 3.3)

Figures 3.6, 3.7, and 3.8 give the $\mathrm{NH}_{3}$ slip from the $\mathrm{SCRF}^{\circledR}$ for different test points at different ANR, for PM loading of 0,2 , and $4 \mathrm{~g} / \mathrm{L}$. The $\mathrm{NH}_{3}$ slip is a function of the urea injected and the ANR value at the inlet of $\mathrm{SCRF}^{\circledR}$. In Figure 3.6, the $\mathrm{NH}_{3}$ slip at ANR - 0.8 for test points 1,3 , and 6 are below 5 ppm. Figure 3.7 shows the $\mathrm{NH}_{3}$ slip for ANR - 1 rising with increasing temperature. This can be attributed to $\mathrm{NH}_{3}$ slip by $\mathrm{PM}$ oxidation at high $\mathrm{SCRF}^{\circledR}$ inlet temperature because there is more $\mathrm{NH}_{3}$ storage in the loaded $\mathrm{SCRF}^{\circledR}[8]$.

Figures 3.6, 3.7, and 3.8 show that the trend of $\mathrm{NH}_{3}$ slip with loading is the same with ANR $-0.8,1$, and 1.2 for all individual test points. It is observed that the $\mathrm{NH}_{3}$ slip for $2 \mathrm{~g} / \mathrm{L}$ loading is lower than the $\mathrm{NH}_{3}$ slip for 0 or $4 \mathrm{~g} / \mathrm{L}$ loading in all figures. Figure 3.8 shows non uniform trend of $\mathrm{NH}_{3}$ slip with temperature. The duration of test to obtain the $\mathrm{NH}_{3}$ slip concentration at each $\mathrm{ANR}$ value in a test point was 10 minutes only which might not be sufficient enough to stabilize the readings. The oxidation of $\mathrm{NH}_{3}$ to $\mathrm{N}_{2}$ and $\mathrm{NO}$ is a dominant reaction at temperatures above $400^{\circ} \mathrm{C}$ [1].

The nitrogen balance across the $\mathrm{SCRF}^{\circledR}$ is shown in Tables 3.7 and 3.9 and was calculated and checked to ensure data consistency. The expression for nitrogen balance is given by:

SCRF® Nitrogen Balance (\%)

$$
=\left\{1-\frac{\text { Inlet } \mathrm{NH}_{3}-\left(\left(\text { Inlet } \mathrm{NO}_{\mathrm{x}}-\text { Outlet } \mathrm{NO}_{\mathrm{x}}\right)+\text { Oulet } \mathrm{NH}_{3}\right)}{\text { Inlet } \mathrm{NH} 3}\right\} * 100
$$

(Equation 3.4) 
In Table 3.9, the nitrogen balance (\%) below 100\% shows that it could be either measurement error or $\mathrm{N}_{2}, \mathrm{~N}_{2} \mathrm{O}$ species coming out of $\mathrm{SCRF}^{\circledR}$ which are not accounted for in Equation 3.4.

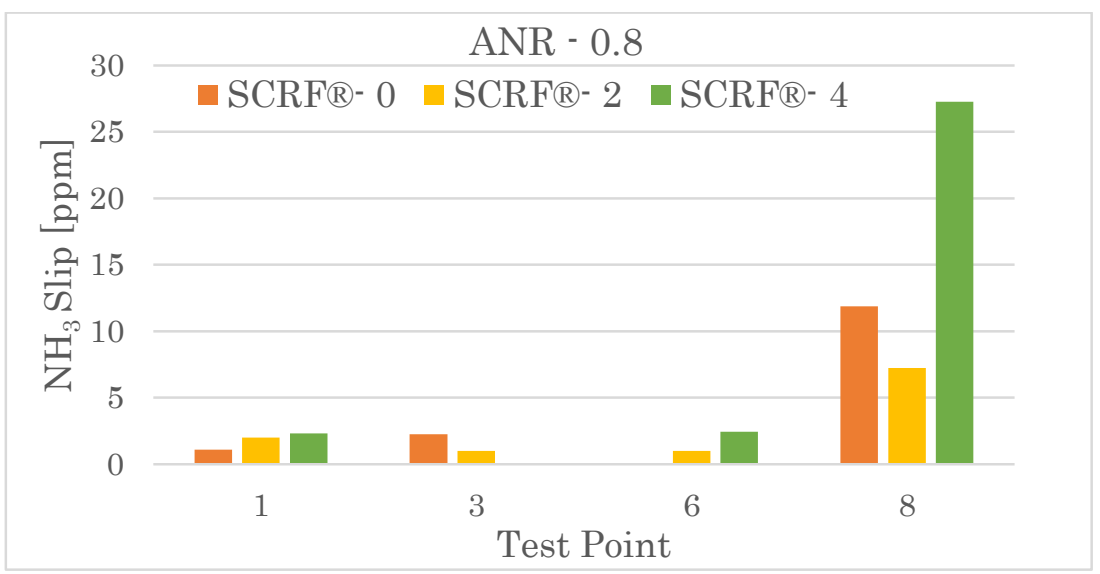

Figure 3.6 $\mathrm{NH}_{3}$ slip from $\mathrm{SCRF}^{\circledR}$ for $\mathrm{NO}_{\mathrm{x}}$ reduction test points at $\mathrm{ANR}-0.8$

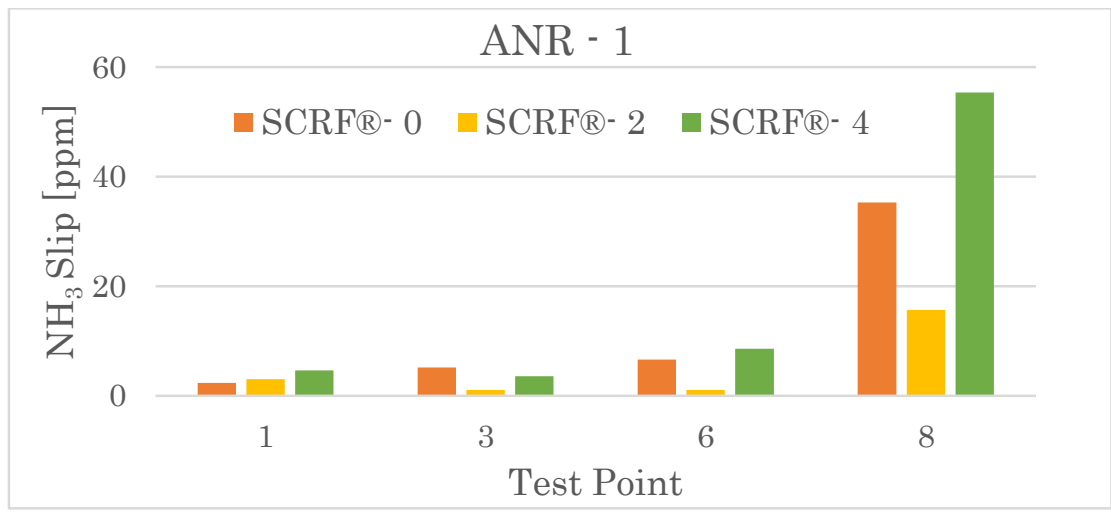

Figure $3.7 \mathrm{NH}_{3}$ slip from $\mathrm{SCRF}^{\circledR}$ for $\mathrm{NO}_{\mathrm{x}}$ reduction test points at $\mathrm{ANR}-1$

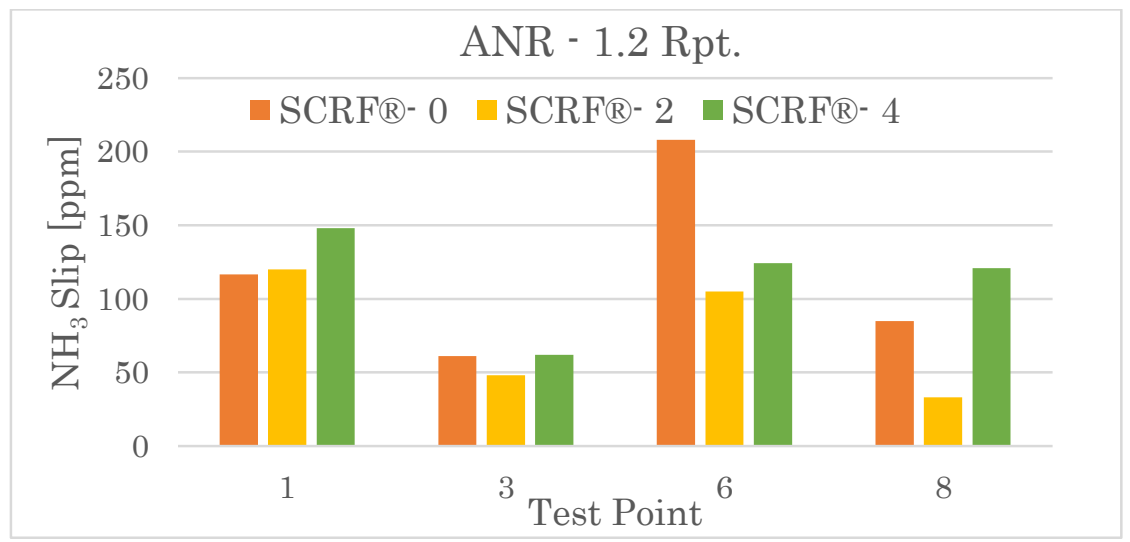

Figure 3.8 $\mathrm{NH}_{3}$ slip from $\mathrm{SCRF}^{\circledR}$ for $\mathrm{NOx}$ reduction test points at $\mathrm{ANR}-1.2$ Repeat (Rpt.) 


\section{Chapter 4. Summary and Conclusions}

Chapter 3 discussed the results of the tests conducted to analyze $\mathrm{NO}_{\mathrm{x}}$ reduction across the $\mathrm{SCRF}^{\circledR}$ and $\mathrm{NH}_{3}$ downstream of the $\mathrm{SCRF}^{\circledR}$. This chapter summarizes the important findings and conclusions of the research presented in this report.

\subsection{Summary}

The objective of the research was to study the effect of PM loading (0, 2, and $4 \mathrm{~g} / \mathrm{L})$ on the $\mathrm{NO}_{\mathrm{x}}$ reduction performance of the $\mathrm{SCRF}^{\circledR}$. The aftertreatment system was comprised of the DOC, CPF and $\mathrm{SCRF}^{\circledR}$. Four test points, named as test point 1, 3, 6, and 8, were conducted for each PM loading condition in the SCRF ${ }^{\circledR}$. For the test without PM loading, the CPF was placed before the $\mathrm{SCRF}^{\circledR}$ in order to filter the PM entering the $\mathrm{SCRF}^{\circledR}$ whereas for tests with PM loading, the spacer was placed in place of the CPF.

\section{Loading Stages}

The engine was run at $2400 \mathrm{rpm}$ engine speed and $200 \mathrm{Nm}$ engine load to load PM in the $\mathrm{SCRF}^{\circledR}$. The fuel rail pressure was reduced to 1050 bar and 750 bar to load PM to $2 \mathrm{~g} / \mathrm{L}$ and $4 \mathrm{~g} / \mathrm{L}$ respectively. The exhaust flow rate was 11.2 and $11.5 \mathrm{~kg} / \mathrm{min}$ for 2 and $4 \mathrm{~g} / \mathrm{L}$ loading respectively for stage 2 . The PM concentration out of engine varied from 17.7 to $21.2 \mathrm{mg} / \mathrm{scm}$ and from 11 to $11.8 \mathrm{mg} / \mathrm{scm}$ for 2 and $4 \mathrm{~g} / \mathrm{L}$ respectively during stage 2. The filtration efficiency for tests with PM loading of 2 and $4 \mathrm{~g} / \mathrm{L}$ had a mean value of $97.4 \%$ and $98.8 \%$, which shows that filtration efficiency improved with loading.

\section{$\mathrm{NO}_{\mathrm{x}}$ Reduction Stage}

The $\mathrm{NO}_{\mathrm{x}}$ reduction stage is conducted after loading the $\mathrm{SCRF}^{\circledR}$ with 0,2 or $4 \mathrm{~g} / \mathrm{L}$ for different test points. During this stage, urea is dosed for in order to obtain ANR values of $0,0.8,1$, and 1.2. The test points were selected from a test matrix to have a wide range of $\mathrm{SCRF}^{\circledR}$ inlet conditions such as $\mathrm{SCRF}^{\circledR}$ inlet temperature, $\mathrm{NO}_{2} / \mathrm{NO}_{\mathrm{x}}$ ratio, and exhaust space velocity. The $\mathrm{NO}_{2} / \mathrm{NO}_{\mathrm{x}}$ ratio at $\mathrm{SCRF}^{\circledR}$ inlet location varied from 0.22 to 0.46 , maximum occurring at $344^{\circ} \mathrm{C}$ (mean) inlet temperature. The space velocity for test point 8 was approximately $48 \mathrm{k} / \mathrm{hr}$, which is highest among the test points. The $\mathrm{NO}_{\mathrm{x}}$ conversion efficiency across the $\mathrm{SCRF}^{\circledR}$ and $\mathrm{NH}_{3}$ slip at the outlet of the $\mathrm{SCRF}^{\circledR}$ 
was determined in order to determine the effect of PM loading in the $\mathrm{SCRF}^{\circledR}$ on $\mathrm{NO}_{\mathrm{x}}$ conversion efficiency and $\mathrm{NH}_{3}$ slip.

\subsection{Conclusions}

The following are the conclusions with respect to the objectives of this study:

1. Without urea dosing, the $\mathrm{NO}_{2}$ concentration at the downstream $\mathrm{SCRF}^{\circledR}$ location decreases with increased PM loading and temperature due to $\mathrm{NO}_{2}$ assisted PM oxidation.

2. The $\mathrm{NO}_{\mathrm{x}}$ conversion efficiency of the $\mathrm{SCRF}^{\circledR}$ has a maxima for the temperature range of $302-347^{\circ} \mathrm{C}$ (test points 3 and 6) where the $\mathrm{NO}_{2} / \mathrm{NO}_{\mathrm{x}}$ ratio values and space velocities lie in the range of $0.42-0.46$ and 18.6-29.8 $\mathrm{k} / \mathrm{hr}$ respectively.

3. The impact of PM loading (from 0 to 2 and $4 \mathrm{~g} / \mathrm{L}$ ) on $\mathrm{NO}_{\mathrm{x}}$ conversion efficiency is not significant for temperature range below $300{ }^{\circ} \mathrm{C}$ however it decreases by $3-5 \%$ above $350{ }^{\circ} \mathrm{C}$, due to consumption of $\mathrm{NO}_{2}$ via passive oxidation of $\mathrm{PM}$.

4. The $\mathrm{NO}_{\mathrm{x}}$ conversion efficiency stays below $95 \%$ for high temperature (around $450{ }^{\circ} \mathrm{C}$ ) test point when dosed with urea with ANR value of 1.2. 


\section{References}

[1] Cavataio, G., Girard, J., and Lambert, C., "Cu/Zeolite SCR on High Porosity Filters: Laboratory and Engine Performance Evaluations," SAE Technical Paper 2009-01-0897, 2009, doi:10.4271/2009-01-0897

[2] Raghavan, Krishnan G., "An Experimental Investigation into the Effect of $\mathrm{NO}_{2}$ and Temperature on the Passive Oxidation and Active Regeneration of Particulate Matter in a Diesel Particulate Filter", Master's Thesis, Michigan Technological University, 2015.

[3] Inc., E. DieselNet: Diesel Emission. 2015; Available from: https://www.dieselnet.com.

[4] "CumminsEngines", https://cumminsengines.com/

[5] Foley, Ryan Kristopher, "Experimental Investigation into Particulate Matter Distribution in Catalyzed Particulate Filters using a 3D Terahertz Wave Scanner", Master's Thesis, Michigan Technological University, 2013.

[6] Vaibhav Kadam, "An Experimental Investigation of the $\mathrm{NO}_{\mathrm{x}}$ Reduction Performance of a $\mathrm{Cu}$-Zeolite Flow-through SCR and a SCR Catalyst on a DPF", Master's Thesis, Michigan Technological University, 2016.

[7] Surenahali, H. S., "Dynamic Model Based State Estimation In a Heavy Duty Diesel Aftertreatment System For Onboard Diagnostics And Controls," PhD Dissertation, Michigan Technological University 2013.

[8] Schrade, F., Brammer, M., Schaeffner, J., Langeheinecke, K. et al., "PhysicoChemical Modeling of an Integrated SCR on DPF (SCR/DPF) System," SAE Int. J. Engines 5(3):958-974, 2012, DOIः 10.4271/2012-01-1083.

[9] Pidgeon, James, "An Experimental Investigation into the effects of Biodiesel Blends on Particulate Matter Oxidation in a Catalyzed Particulate Filter during Active Regeneration", Master's Thesis, Michigan Technological University, 2013 


\section{Appendix A. Particulate Matter Sampling}

The Manual Sampling Train (MST) as shown in Figure A.1 was used for sampling PM at upstream of the DOC and downstream of the SCRF ${ }^{\circledR}$. The MST had a K-type thermocouple to measure exhaust temperature, a vacuum gauge to measure sample pump vacuum, a dry gas meter (DGM) in Figure A.2 to measure exhaust sample volume, a manometer to measure pressure drop at the DGM and a timer to estimate the duration of sampling.

The PM filters were conditioned before the experiment by baking at $850^{\circ} \mathrm{F}$ for 45 minutes. It removed any moisture present on the filter which could have affected the initial mass of the filter. The filter papers were then kept in a glove box environment, which was maintained at consistent humidity $(60 \%)$ and temperature $\left(25^{\circ} \mathrm{C}\right)$ by a tray of desiccant, for 24 hours. The filter papers were weighed using Mettler Toledo UMT2 microbalance before the PM sampling. The filter papers were kept in a box filled with desiccant to avoid moisture absorption by the PM collected on it.

The PM filter probe as shown in Figure A.3 contained the glass fiber filter and was placed at the sample port. To start the sampling, the valve was opened to allow the exhaust to be drawn into the MST. Simultaneously the pump and timer were switched on. The mass of PM retained in the filter is a function of the sampling duration, exhaust flow rate and PM concentration in the exhaust. The valve was then closed and simultaneously the pump and timer were switched off at the end of the sampling duration.

The temperature and the pressure readings were noted at the start and at the end of each PM sample collection. The volume of the exhaust sample was measured by the change in the initial and final reading of DGM. The PM coated filters were weighed using the microbalance after the sampling. The standard concentration of PM $(\mathrm{mg} / \mathrm{scm})$ is defined by the PM mass sampled divided by the volume of the exhaust (cubic meter) sampled converted to standard conditions of $25^{\circ} \mathrm{C}$ and $1 \mathrm{~atm}$. 


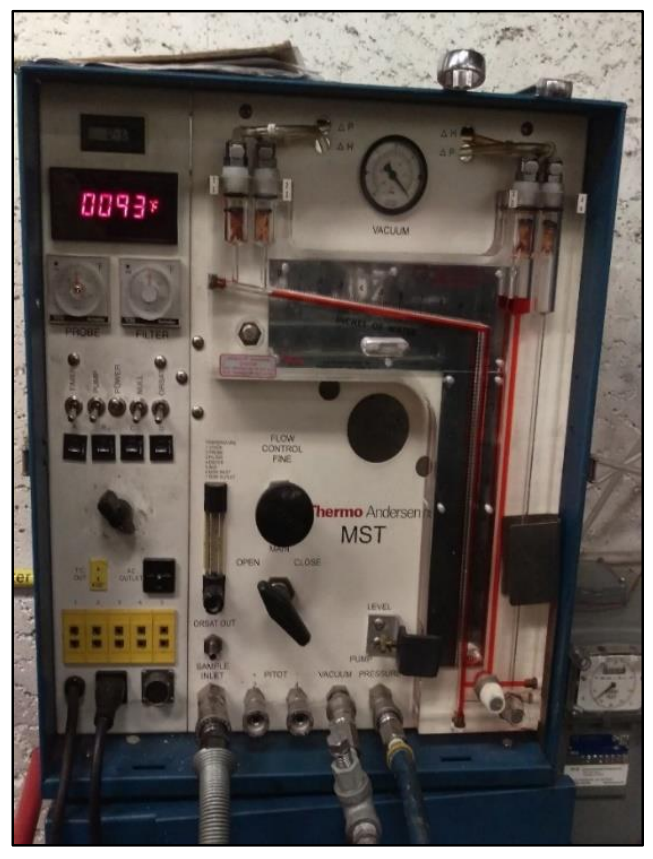

Figure A.1 Manual Sampling Train

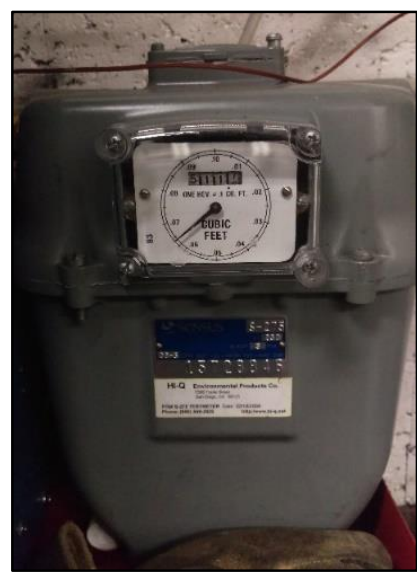

Figure A.2 Dry Gas Meter
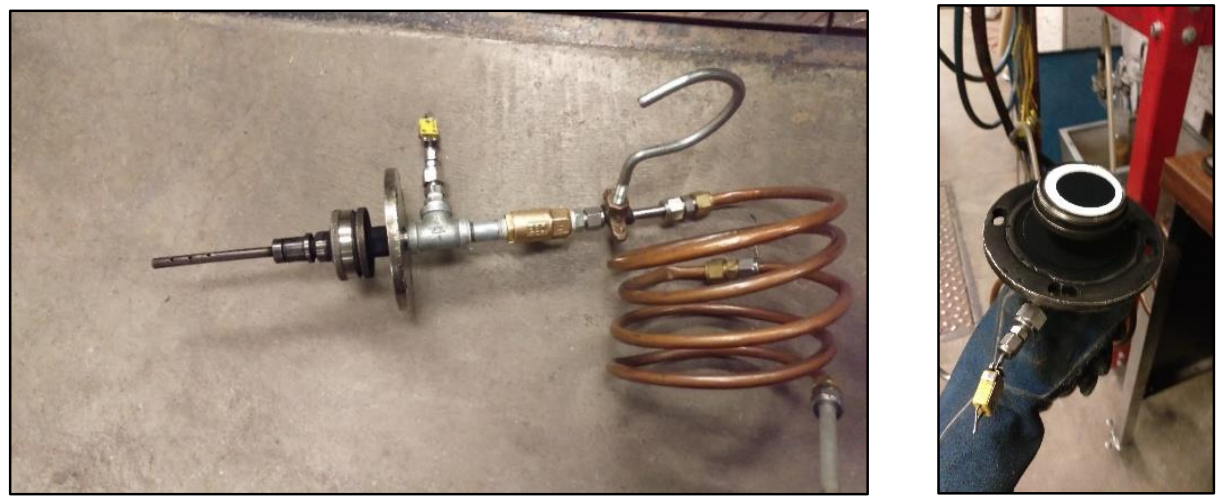

Figure A.3 a) PM sampling probe (left picture) b) Filter paper (right picture) 


\section{Appendix B. SCRF ${ }^{\circledR}$ Weighing}

The $\mathrm{SCRF}^{\circledR}$ was weighed at the end of each loading and $\mathrm{NO}_{\mathrm{x}}$ reduction stage of the test as shown in Figure B.1. It was observed that the weight of $\mathrm{SCRF}^{\circledR}$ block varies with temperature and therefore the $\mathrm{SCRF}^{\circledR}$ was immediately weighed after the engine was shut down [9]. To remove the $\mathrm{SCRF}^{\circledR}$ from the aftertreatment system, first the outlet cone was loosened to prevent air suction from the exhaust system. Later the $\mathrm{SCRF}^{\circledR}$ was disassembled from the aftertreatment system after disconnecting the thermocouples, pressure lines and electrical connections mounted on the SCRF ${ }^{\circledR}$.

The calibration weight was measured to ensure scale accuracy and individual thermocouple readings were recorded. Before weighing the $\mathrm{SCRF}^{\circledR}$, the scale was zeroed prior to each measurement reading. Then the $\mathrm{SCRF}^{\circledR}$ was placed on the scale and three weight readings were noted. The mass of the $\mathrm{SCRF}^{\circledR}$ was calculated by averaging out the three readings.

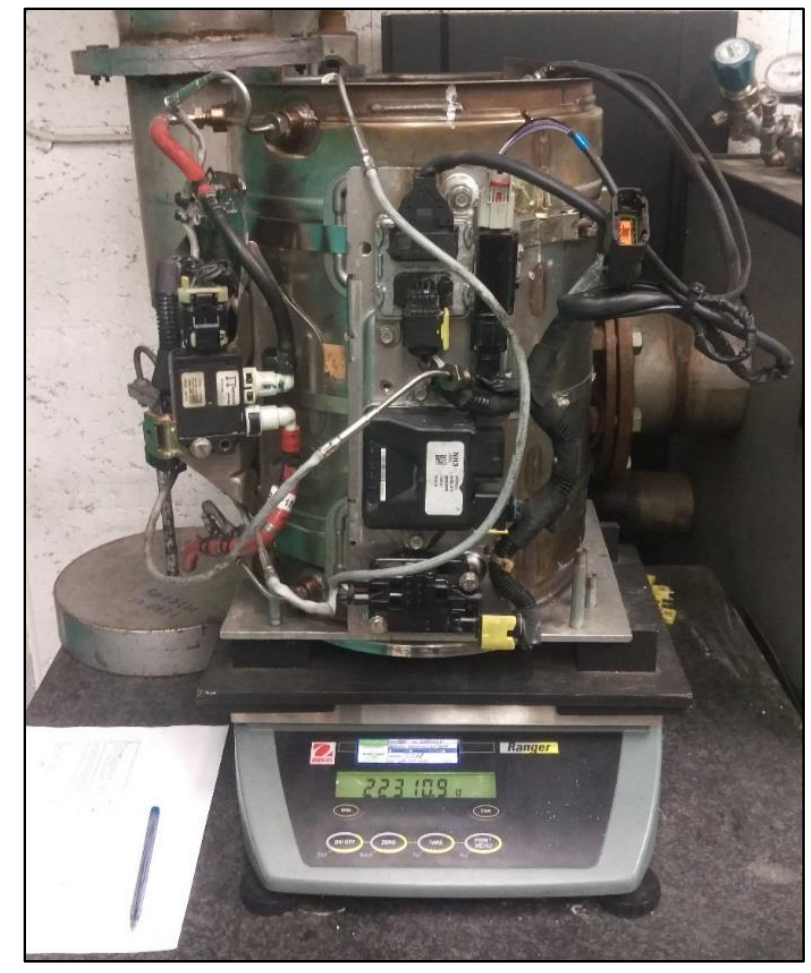

Figure B.1 Weighing of $\mathrm{SCRF}^{\circledR}$ using the Ohaus manufacturer weighing scale 


\section{Appendix C. Engine, Exhaust Conditions and PM Mass Balance for Each Stage}

The engine conditions, $\mathrm{SCRF}^{\circledR}$ conditions and PM mass balance across the $\mathrm{SCRF}^{\circledR}$ is presented for stage 1 , stage 2 and $\mathrm{NO}_{\mathrm{x}}$ reduction stage in this appendix. The engine speed, load, the engine out and $\mathrm{SCRF}^{\circledR}$ inlet (temperature, $\mathrm{NO} / \mathrm{NO}_{2} / \mathrm{NO}_{\mathrm{x}}$ concentration, PM concentration) conditions are analyzed and compared for deviation in Table C.1, C.2, C.5, and C.6. The filtration efficiency of the $\mathrm{SCRF}^{\circledR}$ and PM oxidation in the $\mathrm{SCRF}^{\circledR}$ are summarized in Tables C.3, C.4, C.7, and C.8.

$\mathrm{PM}_{\text {in/out }}(\mathrm{g})$ of the $\mathrm{SCRF}^{\circledR}$ is calculated using the formula:

$$
P M_{\text {in } / \text { out }}=\text { Conc }_{\text {in } / \text { out }} * 10^{-3} * \frac{M F R_{\text {exh }}}{1.18} * t_{\text {stage }}
$$

(Equation C.1)

Where,

$\mathrm{PM}$ in/out is the PM mass in/out of the $\mathrm{SCRF}^{\circledR}[\mathrm{g}]$, Concin is the PM concentration (PM conc.) into the $\mathrm{SCRF}^{\circledR}[\mathrm{mg} / \mathrm{scm}], \mathrm{MFR}_{\text {exh }}$ is the mass flowrate of exhaust [kg/min.], 1.18 is the standard exhaust density at $25^{\circ} \mathrm{C}$ and $1 \mathrm{~atm}$, taken as that of air $\left[\mathrm{kg} / \mathrm{m}^{3}\right], \mathrm{t}_{\text {stage }}$ is the duration of the stage [min]

$\mathrm{PM}_{\text {retained }}(\mathrm{g})$ in the $\mathrm{SCRF}^{\circledR}$ for loading stages is determined from the pre and post stage $\mathrm{SCRF}^{\circledR}$ weight measurements.

PM available (g) in the $\mathrm{SCRF}^{\circledR}$ is the amount of PM entered (PM in from Equation C.1) during the stage in addition to existing PM in the system at the start of the loading stage $\left(\mathrm{m}_{\text {start }}\right)$.

$$
P M_{\text {available }}=P M_{\text {in }}+m_{\text {start }}
$$

(Equation C.2)

PM oxidized $(\mathrm{g})$ is calculated by the subtracting the amount of PM out of the $\mathrm{SCRF}^{\circledR}$ and $\mathrm{PM}_{\text {retained }}$ in the $\mathrm{SCRF}^{\circledR}$ from the $\mathrm{PM}$ in during the stage.

$$
P M_{\text {oxidized }}=P M_{\text {in }}-P M_{\text {retained }}-P M_{\text {out }}
$$

(Equation C.3) 


\section{Stage 1 and Stage 2 at 2 g/L Loading}

It is seen from Tables C.1 and C.2 that the species concentration (NO, $\mathrm{NO}_{2}$ and $\left.\mathrm{NO}_{\mathrm{x}}\right)$ and engine out PM concentration are consistent for all test points. The speed and load values are kept at constant values of 2400 RPM and $200 \mathrm{Nm}$ and have very small deviation. The average engine-out particulate matter is $11.4 \mathrm{mg} / \mathrm{scm}$ (milligrams /standard cubic meter) and is consistent for all tests with a standard deviation of $0.5 \mathrm{mg} / \mathrm{scm}$ and $0.3 \mathrm{mg} / \mathrm{scm}$ for stage 1 and stage 2 respectively.

The parameters such as $\mathrm{PM}$ concentration into $\mathrm{SCRF}^{\circledR}, \mathrm{NO}_{2} / \mathrm{PM}$ ratio, temperature into $\mathrm{SCRF}^{\circledR}$ and loading duration which affected the PM deposition and oxidation in the $\mathrm{SCRF}^{\circledR}$ are given in Tables C.3 and C.4. The test point 3 (2401 rpm engine speed, $203 \mathrm{Nm}$ load) has least PM retention of $27.9 \mathrm{~g}$ in the $\mathrm{SCRF}^{\circledR}$ for the high PM amount coming into the $\mathrm{SCRF}^{\circledR}$ and hence high $\mathrm{PM}$ available for oxidation. Another reason was that the test point 3 was run for least time period of approximately 300 minutes.

PM oxidation (percentage) in stage 1 as shown in Table C.3 has the similar trend to that of PM oxidation (percentage) in stage 2 as shown in Table C.4. This is because mass loaded in stage 1 is estimated assuming the same rate of loading as in stage 2 . The filtration efficiency is obtained using the samples collected during stage 2 which is considered to be same for stage 1 . 
Table C.1 Engine and $\mathrm{SCRF}^{\circledR}$ conditions for Stage 1 at $2 \mathrm{~g} / \mathrm{L}$ loading

\begin{tabular}{|c|c|c|c|c|c|c|c|c|c|c|}
\hline $\begin{array}{l}\text { Test } \\
\text { Point }\end{array}$ & Speed & Load & $\begin{array}{c}\text { Temp. } \\
\text { into } \\
\text { SCRF } \\
\end{array}$ & $\begin{array}{l}\text { Exhaust } \\
\text { Flowrate }\end{array}$ & $\begin{array}{c}\text { SCRF }^{\circledR} \\
\text { Std. } \\
\text { Space } \\
\text { Vel. }\end{array}$ & $\begin{array}{c}\text { SCRF }^{\circledR} \\
\text { Act. } \\
\text { Space } \\
\text { Vel. }\end{array}$ & $\begin{array}{c}\text { NO } \\
\text { into } \\
\text { SCRF } \\
{ }_{\circledast}\end{array}$ & $\begin{array}{c}\mathrm{NO}_{2} \\
\text { into } \\
\mathrm{SCRF} \\
\mathbb{B}\end{array}$ & $\begin{array}{c}\mathrm{NO}_{\mathrm{x}} \\
\text { into } \\
\mathrm{SCRF} \\
{ }_{\mathbb{B}}\end{array}$ & $\begin{array}{c}\text { Engine } \\
\text { Out } \\
\text { PM conc. }\end{array}$ \\
\hline$[-]$ & [RPM] & {$[\mathrm{N}-\mathrm{m}]$} & [C] & {$[\mathrm{kg} / \mathrm{min}]$} & {$[\mathrm{k} / \mathrm{hr}]$} & {$[\mathrm{k} / \mathrm{hr}]$} & [ppm] & [ppm] & [ppm] & {$[\mathrm{mg} / \mathrm{scm}]$} \\
\hline 1 & 2383 & 205 & 276 & 11.2 & 30.5 & 57.6 & 118 & 62 & 180 & 11.0 \\
\hline 3 & 2395 & 205 & 274 & 11.2 & 33.3 & 57.3 & 138 & 38 & 176 & 12.2 \\
\hline 6 & 2400 & 203 & 274 & 11.2 & 33.5 & 57.6 & 118 & 72 & 190 & 11.4 \\
\hline 8 & 2397 & 201 & 284 & 11.3 & 33.7 & 59.1 & 124 & 66 & 190 & 11.0 \\
\hline Mean & 2394 & 204 & 277 & 11.2 & 32.7 & 57.9 & 124 & 59 & 184 & 11.4 \\
\hline $\begin{array}{l}\text { Std. } \\
\text { Dev. }\end{array}$ & 7 & 2 & 5 & 0.1 & 1.5 & 0.8 & 9 & 15 & 7 & 0.5 \\
\hline $\begin{array}{c}\text { ULI } \\
\text { M } \\
95 \%\end{array}$ & 2401 & 205 & 282 & 11.3 & 34.2 & 58.7 & 134 & 74 & 191 & 11.9 \\
\hline $\begin{array}{c}\text { LLI } \\
\text { M } \\
95 \%\end{array}$ & 2387 & 202 & 272 & 11.2 & 31.3 & 57.1 & 115 & 45 & 177 & 10.9 \\
\hline $\begin{array}{c}95 \% \\
\text { CI }\end{array}$ & 14 & 3 & 9 & 0.1 & 2.9 & 1.6 & 18 & 29 & 14 & 1.1 \\
\hline
\end{tabular}

Table C.2 Engine and SCRF ${ }^{\circledR}$ conditions for Stage 2 at 2 g/L loading

\begin{tabular}{|c|c|c|c|c|c|c|c|c|c|c|c|}
\hline $\begin{array}{l}\text { Test } \\
\text { Point }\end{array}$ & Speed & Load & $\begin{array}{c}\text { Temp. } \\
\text { into } \\
\text { SCRF }\end{array}$ & $\begin{array}{l}\text { Exh. } \\
\text { Flow } \\
\text {-rate }\end{array}$ & $\begin{array}{c}\text { SCRF } \\
\text { B Std. } \\
\text { Space } \\
\text { Vel. }\end{array}$ & $\begin{array}{c}\text { SCRF } \\
{ }^{\circledR} \text { Act. } \\
\text { Space } \\
\text { Vel. }\end{array}$ & $\begin{array}{c}\text { NO } \\
\text { into } \\
\text { SCRF } \\
\text { ® }\end{array}$ & $\begin{array}{c}\mathrm{NO}_{2} \\
\text { into } \\
\text { SCRF } \\
\end{array}$ & $\begin{array}{c}\mathrm{NO}_{\mathbf{x}} \\
\text { into } \\
\text { SCRF } \\
\text { ® }\end{array}$ & $\begin{array}{l}\text { Engine } \\
\text { Out PM }\end{array}$ & $\begin{array}{c}\text { SCRF }^{\circledR} \\
\text { delta P } \\
\text { at the } \\
\text { end of } \\
\text { S2 }\end{array}$ \\
\hline$[-]$ & [RPM] & [N-m] & [C] & $\begin{array}{c}{[\mathrm{kg} / \mathrm{mi}} \\
\mathrm{n}]\end{array}$ & {$[\mathrm{k} / \mathrm{hr}]$} & {$[\mathrm{k} / \mathrm{hr}]$} & [ppm] & [ppm] & [ppm] & {$[\mathrm{mg} / \mathrm{scm}]$} & {$[\mathrm{kPa}]$} \\
\hline 1 & 2401 & 203 & 279 & 11.3 & 30.7 & 58.3 & 114 & 82 & 196 & 11.0 & 6.6 \\
\hline 3 & 2401 & 203 & 274 & 11.2 & 30.5 & 57.3 & 131 & 56 & 187 & 11.8 & 6.4 \\
\hline 6 & 2399 & 200 & 269 & 11.3 & 30.8 & 57.5 & 122 & 65 & 186 & 11.4 & 6.3 \\
\hline 8 & 2399 & 202 & 274 & 11.2 & 30.6 & 57.7 & 127 & 69 & 197 & 11.2 & 6.2 \\
\hline Mean & 2400 & 202 & 274 & 11.2 & 30.7 & 57.7 & 123 & 68 & 191 & 11.4 & 6.4 \\
\hline $\begin{array}{l}\text { Std. } \\
\text { Dev. }\end{array}$ & 1 & 1 & 4 & 0.1 & 0.1 & 0.4 & 7 & 11 & 6 & 0.3 & 0.2 \\
\hline $\begin{array}{c}\text { ULIM } \\
95 \%\end{array}$ & 2401 & 203 & 278 & 11.3 & 30.8 & 58.1 & 131 & 79 & 197 & 11.7 & 6.5 \\
\hline $\begin{array}{c}\text { LLIM } \\
95 \%\end{array}$ & 2399 & 201 & 270 & 11.2 & 30.5 & 57.3 & 116 & 57 & 186 & 11.0 & 6.2 \\
\hline $\begin{array}{c}95 \% \\
\text { CI }\end{array}$ & 2 & 2 & 8 & 0.1 & 0.3 & 0.8 & 15 & 21 & 11 & 0.7 & 0.3 \\
\hline
\end{tabular}


Table C.3 Particulate matter mass balance during Stage 1 at 2 g/L loading

\begin{tabular}{|c|c|c|c|c|c|c|c|c|c|c|c|}
\hline $\begin{array}{l}\text { Test } \\
\text { Point }\end{array}$ & $\begin{array}{c}\text { PM } \\
\text { Conc. } \\
\text { Into } \\
\text { SCRF } \\
\circledast \infty\end{array}$ & $\begin{array}{c}\mathrm{NO}_{2} / \mathrm{P} \\
\text { M Ratio }\end{array}$ & $\begin{array}{c}\mathrm{NO}_{\mathrm{x}} / \mathrm{PM} \\
\text { Ratio }\end{array}$ & $\begin{array}{l}\text { Filtration } \\
\text { Efficiency } \\
\text { of SCRF }\end{array}$ & $\begin{array}{c}\text { PM } \\
\text { Into } \\
\text { SCRF } \\
\text { during } \\
\text { S1 }\end{array}$ & $\begin{array}{c}\text { PM } \\
\text { Mass } \\
\text { Out of } \\
\text { SCRF } \\
\text { during } \\
\text { S1 }\end{array}$ & $\begin{array}{c}\text { Total PM } \\
\text { deposited } \\
\text { in } \\
\text { SCRF } \\
\text { by the } \\
\text { end of } S 1\end{array}$ & $\begin{array}{c}\text { PM } \\
\text { Mass } \\
\text { Oxidized } \\
\text { during } \\
\text { S1 }\end{array}$ & $\begin{array}{l}\text { PM Mass } \\
\text { Retained } \\
\text { at the end } \\
\text { of } S 1\end{array}$ & Duration & $\begin{array}{c}\% \\
\text { Oxidized }\end{array}$ \\
\hline$[-]$ & {$[\mathrm{mg} / \mathrm{scm}]$} & $\begin{array}{c}{[\mathrm{mg}} \\
\mathrm{NO}_{2}: \mathrm{mg} \\
\mathrm{PM}] \\
\end{array}$ & $\begin{array}{c}\text { [mg } \\
\mathrm{NO}_{\mathrm{x}}: \mathrm{mg} \\
\mathrm{PM}] \\
\end{array}$ & [\%] & [g] & [g] & [g] & [g] & [g] & [min] & [\%] \\
\hline 1 & 11.0 & 10.6 & 30.8 & 96.9 & 3.1 & 0.1 & 3.1 & 0.2 & 2.8 & 30 & $7 \%$ \\
\hline 3 & 12.2 & 5.8 & 27.1 & 97.7 & 3.5 & 0.1 & 3.5 & 0.9 & 2.6 & 31 & $25 \%$ \\
\hline 6 & 11.4 & 11.8 & 31.2 & 97.4 & 3.3 & 0.1 & 3.3 & 0.7 & 2.5 & 31 & $20 \%$ \\
\hline 8 & 11.0 & 11.3 & 32.4 & 97.8 & 3.3 & 0.1 & 3.3 & 0.4 & 2.8 & 32 & $13 \%$ \\
\hline Mean & 11.4 & 9.9 & 30.4 & 97.4 & 3.3 & 0.1 & 3.3 & 0.5 & 2.7 & 31 & $16 \%$ \\
\hline $\begin{array}{l}\text { Std. } \\
\text { Dev. }\end{array}$ & 0.5 & 2.7 & 2.3 & 0.4 & 0.2 & 0.0 & 0.2 & 0.3 & 0.2 & 0 & $8 \%$ \\
\hline $\begin{array}{c}\text { ULIM } \\
95 \%\end{array}$ & 11.9 & 12.6 & 32.6 & 97.8 & 3.5 & 0.1 & 3.5 & 0.8 & 2.8 & 31 & $24 \%$ \\
\hline $\begin{array}{l}\text { LLIM } \\
95 \%\end{array}$ & 10.9 & 7.2 & 28.2 & 97.1 & 3.2 & 0.1 & 3.2 & 0.3 & 2.5 & 30 & $8 \%$ \\
\hline $\begin{array}{c}95 \% \\
\text { CI }\end{array}$ & 1.1 & 5.4 & 4.4 & 0.7 & 0.3 & 0.0 & 0.3 & 0.6 & 0.3 & 1 & $15 \%$ \\
\hline
\end{tabular}


Table C.4 Particulate matter mass balance during Stage 2 at 2 g/L loading

\begin{tabular}{|c|c|c|c|c|c|c|c|c|c|c|c|c|}
\hline $\begin{array}{l}\text { Test } \\
\text { Point }\end{array}$ & $\begin{array}{c}\text { PM } \\
\text { Conc. } \\
\text { Into } \\
\text { SCRF }^{\circledR}\end{array}$ & $\begin{array}{c}\mathrm{NO}_{2} / \mathrm{PM} \\
\text { Ratio }\end{array}$ & $\begin{array}{c}\mathrm{NO}_{\mathrm{x}} / \mathrm{PM} \\
\text { Ratio }\end{array}$ & $\begin{array}{l}\text { Filtration } \\
\text { Efficiency } \\
\text { of SCRF }\end{array}$ & $\begin{array}{c}\text { PM } \\
\text { Into } \\
\text { SCRF } \\
\text { during } \\
\text { S2 }\end{array}$ & $\begin{array}{c}\text { PM } \\
\text { Mass } \\
\text { Out of } \\
\text { SCRF } \\
\text { during } \\
\text { S2 } \\
\end{array}$ & $\begin{array}{c}\text { Total PM } \\
\text { deposited } \\
\text { in } \\
\text { SCRF } \\
\text { by the } \\
\text { end of S2 }\end{array}$ & $\begin{array}{c}\text { PM } \\
\text { Mass } \\
\text { Oxidized } \\
\text { during } \\
\text { S2 }\end{array}$ & $\begin{array}{c}\text { PM } \\
\text { Mass } \\
\text { Retained } \\
\text { at the } \\
\text { end of } \\
\text { S2 }\end{array}$ & Duration & \%Oxidized & $\begin{array}{c}\text { PM } \\
\text { Loading } \\
\text { at the } \\
\text { end of } \\
\text { S2 }\end{array}$ \\
\hline$[-]$ & {$[\mathrm{mg} / \mathrm{scm}]$} & $\begin{array}{c}\mathrm{mg} \\
\mathrm{NO}_{2}: \\
\mathrm{mg} \mathrm{PM} \\
\end{array}$ & $\begin{array}{c}\text { [mg } \\
\text { NO }_{\mathrm{x}}: \\
\text { mg PM] }\end{array}$ & [\%] & [g] & [g] & [g] & {$[\mathrm{g}]$} & [g] & [min] & [\%] & {$[\mathrm{g} / \mathrm{L}]$} \\
\hline 1 & 11.0 & 14.1 & 33.5 & 96.9 & 34.6 & 1.1 & 37.4 & 3.0 & 33.3 & 330 & $8 \%$ & 2.0 \\
\hline 3 & 11.8 & 9.0 & 29.8 & 97.7 & 33.5 & 0.8 & 36.1 & 7.4 & 27.9 & 300 & $21 \%$ & 1.6 \\
\hline 6 & 11.4 & 10.6 & 30.6 & 97.4 & 36.6 & 1.0 & 39.1 & 8.0 & 30.1 & 334 & $20 \%$ & 1.8 \\
\hline 8 & 11.2 & 11.6 & 32.9 & 97.8 & 35.3 & 0.8 & 38.1 & 4.8 & 32.5 & 330 & $13 \%$ & 1.9 \\
\hline Mean & 11.4 & 11.3 & 31.7 & 97.4 & 35.0 & 0.9 & 37.7 & 5.8 & 31.0 & 323 & $15 \%$ & 1.8 \\
\hline $\begin{array}{l}\text { Std. } \\
\text { Dev. }\end{array}$ & 0.3 & 2.1 & 1.8 & 0.4 & 1.3 & 0.1 & 1.3 & 2.4 & 2.5 & 16 & $6 \%$ & 0.1 \\
\hline $\begin{array}{l}\text { ULIM } \\
95 \%\end{array}$ & 11.7 & 13.4 & 33.5 & 97.8 & 36.2 & 1.0 & 38.9 & 8.1 & 33.4 & 339 & $22 \%$ & 2.0 \\
\hline $\begin{array}{l}\text { LLIM } \\
95 \%\end{array}$ & 11.0 & 9.2 & 30.0 & 97.1 & 33.7 & 0.8 & 36.4 & 3.5 & 28.5 & 308 & $9 \%$ & 1.7 \\
\hline $\begin{array}{c}95 \% \\
\text { CI }\end{array}$ & 0.7 & 4.2 & 3.5 & 0.7 & 2.5 & 0.3 & 2.5 & 4.6 & 4.9 & 31 & $12 \%$ & 0.3 \\
\hline
\end{tabular}




\section{Stage 1 and Stage 2 at $4 \mathrm{~g} / \mathrm{L}$ Loading}

Tables C.5 and C.6 give the data for engine speed, load, SCRF ${ }^{\circledR}$ inlet species concentration and engine out PM for all test points. The average engine-out particulate matter is $18.7 \mathrm{mg} / \mathrm{scm}$ and $19.4 \mathrm{mg} / \mathrm{scm}$ for stage 1 and stage 2 respectively.

Table C.8 shows that the percent PM oxidation for Stage 2, which is consistent for all test points with an average of $24 \%$ and a standard deviation of $3 \%$. The PM retention in the $\mathrm{SCRF}^{\circledR}$ is $4 \mathrm{~g}$ and $69.4 \mathrm{~g}$ for stage 1 and stage 2 respectively. A filtration efficiency of $99.1 \%$ is obtained using the samples collected during stage 2 and is considered to be same for stage 1 . 
Table C.5 Engine and $\mathrm{SCRF}^{\circledR}$ conditions for Stage 1 at $4 \mathrm{~g} / \mathrm{L}$ loading

\begin{tabular}{|c|c|c|c|c|c|c|c|c|c|c|c|}
\hline $\begin{array}{l}\text { Test } \\
\text { Point }\end{array}$ & Speed & Load & $\begin{array}{l}\text { Temp. } \\
\text { into } \\
\text { SCRF }^{\circledR}\end{array}$ & $\begin{array}{l}\text { Exhaust } \\
\text { Flowrate }\end{array}$ & $\begin{array}{l}\text { SCRF }^{\circledR} \\
\text { Std. } \\
\text { Space } \\
\text { Vel. }\end{array}$ & $\begin{array}{c}\text { SCRF }^{\circledR} \\
\text { Act. } \\
\text { Space } \\
\text { Vel. }\end{array}$ & $\begin{array}{l}\text { NO into } \\
\text { SCRF }^{\circledR}\end{array}$ & $\begin{array}{c}\mathrm{NO}_{2} \text { into } \\
\mathrm{SCRF}^{\circledR}\end{array}$ & $\begin{array}{c}\mathrm{NO}_{\mathrm{x}} \\
\text { into } \\
\mathrm{SCRF}^{\circledR}\end{array}$ & $\begin{array}{c}\text { Engine } \\
\text { Out PM } \\
\text { Conc. }\end{array}$ & $\begin{array}{l}\text { SCRF }^{\circledR} \\
\text { delta P }\end{array}$ \\
\hline$[-]$ & [RPM] & [N-m] & {$[\mathrm{C}]$} & [kg/min] & {$[\mathrm{k} / \mathrm{hr}]$} & {$[\mathrm{k} / \mathrm{hr}]$} & [ppm] & [ppm] & [ppm] & {$[\mathrm{mg} / \mathrm{scm}]$} & {$[\mathrm{kPa}]$} \\
\hline 1 & 2401 & 205 & 285 & 11.4 & 31.0 & 61.1 & 112 & 42 & 154 & 15.1 & 3.7 \\
\hline 3 & 2398 & 205 & 285 & 11.4 & 33.9 & 61.0 & 98 & 46 & 144 & 21.2 & 3.7 \\
\hline 6 & 2396 & 201 & 286 & 11.3 & 33.8 & 61.0 & 101 & 46 & 147 & 18.8 & 3.7 \\
\hline 8 & 2399 & 205 & 294 & 11.4 & 34.0 & 62.2 & 107 & 50 & 157 & 19.7 & 3.8 \\
\hline Mean & 2399 & 204 & 288 & 11.4 & 33.2 & 61.3 & 105 & 46 & 151 & 18.7 & 3.7 \\
\hline $\begin{array}{l}\text { Std. } \\
\text { Dev. }\end{array}$ & 2 & 2 & 5 & 0.0 & 1.5 & 0.6 & 6 & 3 & 6 & 2.6 & 0.1 \\
\hline $\begin{array}{c}\text { ULIM } \\
95 \%\end{array}$ & 2400 & 206 & 292 & 11.4 & 34.6 & 61.9 & 111 & 49 & 157 & 21.2 & 3.8 \\
\hline $\begin{array}{c}\text { LLIM } \\
95 \%\end{array}$ & 2397 & 202 & 283 & 11.3 & 31.7 & 60.8 & 99 & 43 & 145 & 16.2 & 3.6 \\
\hline $95 \%$ CI & 4 & 4 & 9 & 0.1 & 2.9 & 1.1 & 12 & 6 & 12 & 5.0 & 0.1 \\
\hline
\end{tabular}


Table C.6 Engine and $\mathrm{SCRF}^{\circledR}$ conditions for Stage 2 at $4 \mathrm{~g} / \mathrm{L}$ loading

\begin{tabular}{|c|c|c|c|c|c|c|c|c|c|c|c|}
\hline $\begin{array}{l}\text { Test } \\
\text { Point }\end{array}$ & Speed & Load & $\begin{array}{l}\text { Temp. } \\
\text { into } \\
\text { SCRF }^{\circledR}\end{array}$ & $\begin{array}{l}\text { Exhaust } \\
\text { Flowrate }\end{array}$ & $\begin{array}{c}\text { SCRF }^{\circledR} \\
\text { Std. } \\
\text { Space } \\
\text { Vel. }\end{array}$ & $\begin{array}{c}\text { SCRF }^{\circledR} \\
\text { Act. } \\
\text { Space } \\
\text { Vel. }\end{array}$ & $\begin{array}{l}\text { NO into } \\
\text { SCRF }^{\circledR}\end{array}$ & $\begin{array}{c}\mathrm{NO}_{2} \text { into } \\
\mathrm{SCRF}^{\circledR}\end{array}$ & $\begin{array}{c}\mathrm{NO}_{\mathrm{x}} \\
\text { into } \\
\mathrm{SCRF}^{\circledR}\end{array}$ & $\begin{array}{c}\text { Engine } \\
\text { Out PM } \\
\text { Conc. }\end{array}$ & $\begin{array}{c}\mathrm{SCRF}^{\circledR} \\
\text { delta } \mathrm{P} \\
\text { at the } \\
\text { end of } \\
\text { S2 }\end{array}$ \\
\hline$[-]$ & [RPM] & {$[\mathrm{N}-\mathrm{m}]$} & [C] & [kg/min] & {$[\mathrm{k} / \mathrm{hr}]$} & {$[\mathrm{k} / \mathrm{hr}]$} & [ppm] & [ppm] & [ppm] & {$[\mathrm{mg} / \mathrm{scm}]$} & [kPa] \\
\hline 1 & 2401 & 205 & 288 & 11.4 & 31.1 & 58.5 & 110 & 53 & 163 & 17.7 & 9.4 \\
\hline 3 & 2387 & 202 & 283 & 11.3 & 30.9 & 57.8 & 100 & 53 & 153 & 21.2 & 9.1 \\
\hline 6 & 2402 & 204 & 297 & 11.6 & 31.5 & 59.8 & 122 & 54 & 175 & 19.5 & 10.0 \\
\hline 8 & 2402 & 204 & 298 & 11.5 & 31.3 & 59.6 & 102 & 48 & 150 & 19.2 & 9.9 \\
\hline Mean & 2398 & 204 & 291 & 11.5 & 31.2 & 58.9 & 109 & 52 & 161 & 19.4 & 9.6 \\
\hline $\begin{array}{l}\text { Std. } \\
\text { Dev. }\end{array}$ & 8 & 1 & 7 & 0.1 & 0.2 & 0.9 & 10 & 3 & 11 & 1.4 & 0.4 \\
\hline $\begin{array}{c}\text { ULIM } \\
95 \% \\
\end{array}$ & 2405 & 205 & 298 & 11.5 & 31.5 & 59.8 & 118 & 55 & 172 & 20.8 & 10.0 \\
\hline $\begin{array}{c}\text { LLIM } \\
95 \%\end{array}$ & 2390 & 203 & 284 & 11.4 & 31.0 & 58.0 & 99 & 49 & 149 & 18.0 & 9.1 \\
\hline $95 \%$ CI & 15 & 2 & 14 & 0.2 & 0.5 & 1.9 & 19 & 5 & 22 & 2.7 & 0.9 \\
\hline
\end{tabular}


Table C.7 Particulate matter mass balance during Stage 1 at $4 \mathrm{~g} / \mathrm{L}$ loading

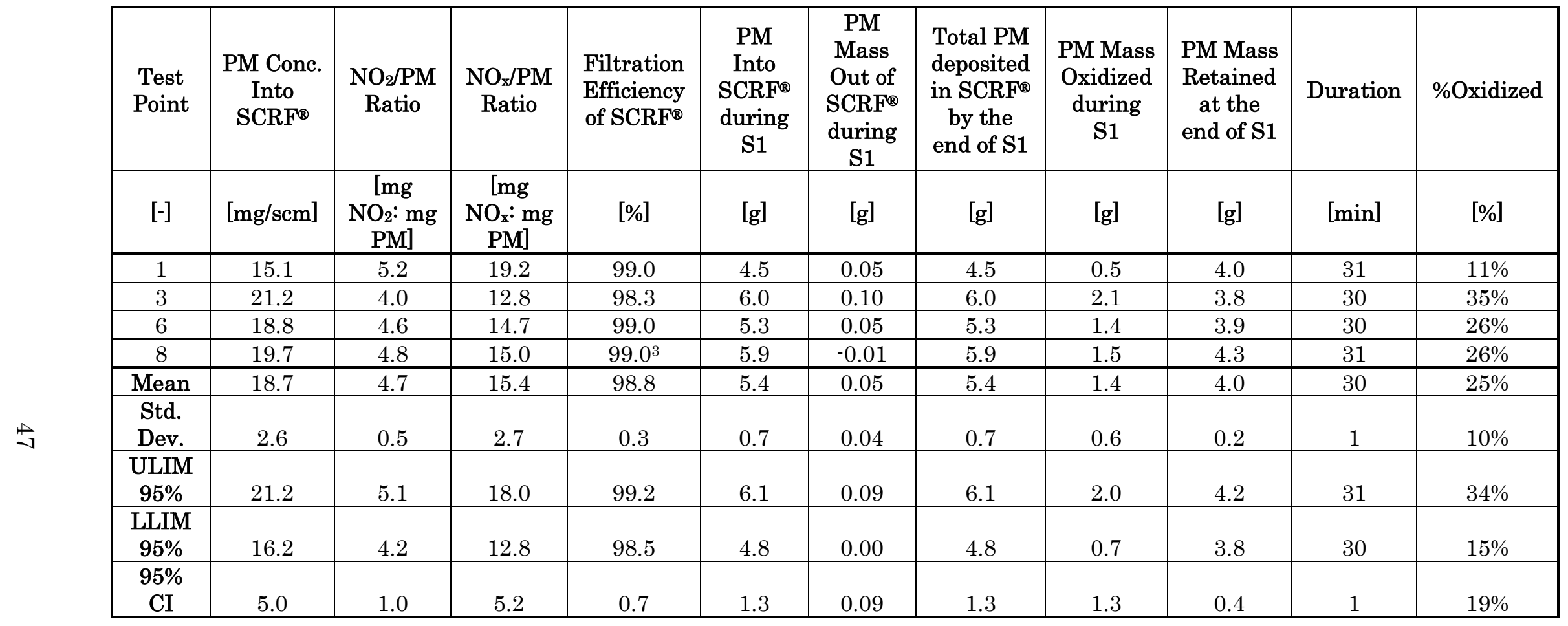


Table C.8 Particulate matter mass balance during Stage 2 at 4 g/L loading

\begin{tabular}{|c|c|c|c|c|c|c|c|c|c|c|c|c|}
\hline $\begin{array}{l}\text { Test } \\
\text { Point }\end{array}$ & $\begin{array}{c}\text { PM } \\
\text { Conc. } \\
\text { Into } \\
\text { SCRF }^{\circledR}\end{array}$ & $\begin{array}{c}\mathrm{NO}_{2} / \mathrm{PM} \\
\text { Ratio }\end{array}$ & $\begin{array}{c}\mathrm{NO}_{\mathrm{x}} / \mathrm{PM} \\
\text { Ratio }\end{array}$ & $\begin{array}{c}\text { Filtration } \\
\text { Efficiency } \\
\text { of } \\
\text { SCRF }^{\circledR}\end{array}$ & $\begin{array}{c}\text { PM } \\
\text { Into } \\
\text { SCRF }^{\circledR} \\
\text { during } \\
\text { S2 }\end{array}$ & $\begin{array}{c}\text { PM } \\
\text { Mass } \\
\text { Out of } \\
\text { SCRF }^{\circledR} \\
\text { during } \\
\text { S2 }\end{array}$ & $\begin{array}{c}\text { Total PM } \\
\text { deposited } \\
\text { in } \\
\text { SCRF } \\
\text { by the } \\
\text { end of S2 }\end{array}$ & $\begin{array}{c}\text { PM } \\
\text { Mass } \\
\text { Oxidized } \\
\text { during } \\
\text { S2 }\end{array}$ & $\begin{array}{c}\text { PM } \\
\text { Mass } \\
\text { Retained } \\
\text { at the } \\
\text { end of } \\
\text { S2 }\end{array}$ & Duration & \%Oxidized & $\begin{array}{c}\text { PM } \\
\text { Loading } \\
\text { at the } \\
\text { end of } \\
\text { S2 }\end{array}$ \\
\hline$[-]$ & {$[\mathrm{mg} / \mathrm{scm}]$} & $\begin{array}{c}\text { [mg } \\
\mathrm{NO}_{2}: \\
\mathrm{mg} \mathrm{PM}]\end{array}$ & $\begin{array}{c}\text { [mg } \\
\mathrm{NO}_{\mathrm{x}}: \\
\mathrm{mg} \mathrm{PM}]\end{array}$ & {$[\%]$} & [g] & [g] & [g] & [g] & [g] & [min] & [\%] & {$[\mathrm{g} / \mathrm{L}]$} \\
\hline 1 & 17.7 & 5.6 & 17.3 & 99.0 & 87.7 & 0.9 & 91.7 & 21.6 & 69.2 & 511 & $24 \%$ & 4.1 \\
\hline 3 & 21.2 & 4.7 & 13.6 & 98.3 & 93.6 & 1.6 & 97.4 & 34.3 & 61.5 & 460 & $21 \%$ & 3.6 \\
\hline 6 & 19.5 & 5.2 & 16.9 & 99.0 & 97.5 & 1.0 & 101.4 & 29.3 & 71.1 & 510 & $29 \%$ & 4.2 \\
\hline 8 & 19.2 & 4.7 & 14.7 & $99.0^{1}$ & 95.5 & -0.1 & 99.8 & 24.2 & 75.7 & 510 & $24 \%$ & 4.4 \\
\hline Mean & 19.4 & 5.0 & 15.6 & 98.8 & 93.6 & 0.8 & 97.6 & 27.4 & 69.4 & 497 & $24 \%$ & 4.1 \\
\hline $\begin{array}{l}\text { Std. } \\
\text { Dev. }\end{array}$ & 1.4 & 0.4 & 1.8 & 0.3 & 4.2 & 0.7 & 4.2 & 5.6 & 5.9 & 25 & $3 \%$ & 0.3 \\
\hline $\begin{array}{c}\text { ULIM } \\
95 \%\end{array}$ & 20.8 & 5.5 & 17.3 & 99.2 & 97.7 & 1.5 & 101.7 & 32.9 & 75.2 & 522 & $28 \%$ & 4.4 \\
\hline $\begin{array}{c}\text { LLIM } \\
95 \% \\
\end{array}$ & 18.0 & 4.6 & 13.9 & 98.5 & 89.4 & 0.1 & 93.4 & 21.8 & 63.6 & 473 & $21 \%$ & 3.7 \\
\hline $\begin{array}{c}95 \% \\
\mathrm{CI} \\
\end{array}$ & 2.7 & 0.9 & 3.4 & 0.7 & 8.3 & 1.4 & 8.3 & 11.1 & 11.6 & 49 & $7 \%$ & 0.7 \\
\hline
\end{tabular}

1 The value is taken same as that for test point 6 since the filter paper was damaged at the downstream location during sampling. 


\section{Appendix D. Gaseous Emissions by Stage}

This appendix discusses the emission species for stage 1 and the $\mathrm{NO}_{\mathrm{x}}$ reduction stage runs. The $\mathrm{NO}_{\mathrm{x}}$ reduction stage test results for ANR 1 and 1.2 are discussed in Chapter 3 and the results for ANR 0, 0.8, and 1.2 (repeat) are summarized in this section in Tables D.3 through D.8. The positive and negative values of NO conversion efficiency show reduction and increment in $\mathrm{NO}$ concentration across the components (DOC, $\mathrm{SCRF}^{\circledR}$ ) respectively.

All the measurements presented in the table are from Mass Spectrometer (IMR-MS). Due to problems with the Mass Spectrometer emission analyzer, the $\mathrm{NO}_{2}$ species ppm was not available correctly at the upstream DOC location for the test points. The correct species measurements were obtained in tests with $4 \mathrm{~g} / \mathrm{L}$ loading after the maintenance of IMR-MS by $\mathrm{V} \& \mathrm{~F}$. The $\mathrm{NO}_{\mathrm{x}}$ is determined as the sum of $\mathrm{NO}$ and $\mathrm{NO}_{2}$ concentrations at the respective locations. The effect of loading on $\mathrm{NO}_{\mathrm{x}}$ reduction efficiency at different test points can be seen in Figure D.1 for ANR-1.2 Repeat.

\section{Stage 1 and Stage 2 Loading at $2 \mathrm{~g} / \mathrm{L}$}

Table D.1 NO, $\mathrm{NO}_{2}, \mathrm{NO}_{\mathrm{x}}$ concentration at upstream and downstream locations of DOC and $\mathrm{SCRF}^{\circledR}$ during Stage 1 loading at $2 \mathrm{~g} / \mathrm{L}$

\begin{tabular}{|c|c|c|c|c|c|c|c|c|c|c|c|}
\hline \multirow{2}{*}{$\begin{array}{l}\text { Test } \\
\text { Point }\end{array}$} & \multicolumn{3}{|c|}{ NO } & \multicolumn{3}{|c|}{$\mathrm{NO}_{2}$} & \multicolumn{3}{|c|}{$\mathrm{NO}_{\mathrm{x}}$} & \multicolumn{2}{|c|}{$\begin{array}{c}\text { NO } \\
\text { Conv. }\end{array}$} \\
\hline & $\begin{array}{c}\mathrm{U} \\
\mathrm{DOC}\end{array}$ & $\begin{array}{c}\mathrm{U} \\
\mathrm{SCRF}^{\circledR}\end{array}$ & $\begin{array}{c}\mathrm{D} \\
\mathrm{SCRF}^{\circledR}\end{array}$ & $\begin{array}{c}\text { U } \\
\text { DOC }\end{array}$ & $\begin{array}{c}\mathrm{U} \\
\mathrm{SCRF}^{\circledR}\end{array}$ & $\begin{array}{c}\mathrm{D} \\
\mathrm{SCRF}^{\circledR}\end{array}$ & $\begin{array}{c}\text { U } \\
\text { DOC }\end{array}$ & $\begin{array}{c}\mathrm{U} \\
\mathrm{SCRF}^{\otimes}\end{array}$ & $\begin{array}{c}\text { D } \\
\text { SCRF }^{\circledast}\end{array}$ & DOC & SCRF $^{\circledR}$ \\
\hline$[-]$ & [ppm] & [ppm] & [ppm] & [ppm] & [ppm] & [ppm] & [ppm] & [ppm] & [ppm] & [\%] & [\%] \\
\hline 1 & 182 & 118 & 127 & 1 & 62 & 50 & 183 & 180 & 177 & 35 & -8 \\
\hline 3 & 170 & $138^{1}$ & $132^{1}$ & 1 & 38 & 39 & 171 & 176 & 171 & 19 & 4 \\
\hline 6 & 181 & 118 & 130 & 1 & 72 & 58 & 182 & 190 & 188 & 35 & -10 \\
\hline 8 & 181 & 124 & 129 & 1 & 66 & 55 & 182 & 190 & 184 & 32 & -4 \\
\hline Mean & 179 & 124 & 130 & 1 & 59 & 50 & 180 & 184 & 180 & 30 & -5 \\
\hline $\begin{array}{l}\text { Std. } \\
\text { Dev. }\end{array}$ & 6 & 9 & 2 & 0 & 15 & 8 & 6 & 7 & 8 & 8 & 6 \\
\hline $\begin{array}{c}\text { ULIM } \\
95 \%\end{array}$ & 184 & 134 & 132 & 1 & 74 & 58 & 185 & 191 & 187 & 38 & 2 \\
\hline $\begin{array}{c}\text { LLIM } \\
95 \%\end{array}$ & 173 & 115 & 127 & 1 & 45 & 42 & 174 & 177 & 172 & 23 & -11 \\
\hline $\begin{array}{c}95 \% \\
\text { CI }\end{array}$ & 11 & 18 & 4 & 0 & 29 & 16 & 11 & 14 & 15 & 15 & 12 \\
\hline
\end{tabular}

${ }^{1}$ The concentration of $\mathrm{NO}$ at $\mathrm{USCRF}^{\circledR}$ and $\mathrm{DSCRF}^{\circledR}$ are flagged because of calibration issues with the mass spectrometer during test point 3. 
Table D.2 NO, $\mathrm{NO}_{2}, \mathrm{NO}_{\mathrm{x}}$ concentration at upstream and downstream locations of DOC and $\mathrm{SCRF}^{\circledR}$ during Stage 2 loading at $2 \mathrm{~g} / \mathrm{L}$

\begin{tabular}{|c|c|c|c|c|c|c|c|c|c|c|c|}
\hline \multirow{2}{*}{$\begin{array}{l}\text { Test } \\
\text { Point }\end{array}$} & \multicolumn{3}{|c|}{ NO } & \multicolumn{3}{|c|}{$\mathrm{NO}_{2}$} & \multicolumn{3}{|c|}{$\mathrm{NO}_{\mathrm{x}}$} & \multicolumn{2}{|c|}{ NO Conv. \% } \\
\hline & $\begin{array}{c}\mathrm{U} \\
\mathrm{DOC}\end{array}$ & $\begin{array}{c}\mathrm{U} \\
\text { SCRF }^{\circledR}\end{array}$ & $\begin{array}{c}\text { D } \\
\text { SCRF }^{\circledR}\end{array}$ & $\begin{array}{c}\mathrm{U} \\
\mathrm{DOC}\end{array}$ & $\begin{array}{c}\mathrm{U} \\
\text { SCRF }^{\otimes}\end{array}$ & $\begin{array}{c}\text { D } \\
\text { SCRF }^{\otimes}\end{array}$ & $\begin{array}{c}\text { U } \\
\text { DOC }\end{array}$ & $\begin{array}{c}\mathrm{U} \\
\text { SCRF }^{\circledR}\end{array}$ & $\begin{array}{c}\text { D } \\
\text { SCRF }^{\circledR}\end{array}$ & DOC & $\mathrm{SCRF}^{\circledR}$ \\
\hline$[-]$ & [ppm] & [ppm] & [ppm] & [ppm] & [ppm] & [ppm] & [ppm] & [ppm] & [ppm] & [\%] & [\%] \\
\hline 1 & 172 & 114 & 136 & 1 & 82 & 51 & 173 & 196 & 187 & 34 & -20 \\
\hline 3 & 180 & 131 & 146 & 1 & 56 & 44 & 181 & 187 & 190 & 27 & -12 \\
\hline 6 & 170 & 122 & 145 & 8 & 65 & 37 & 178 & 186 & 182 & 28 & -19 \\
\hline 8 & 185 & 127 & 133 & 6 & 69 & 51 & 191 & 197 & 184 & 31 & -5 \\
\hline Mean & 177 & 123 & 140 & 4 & 68 & 46 & 181 & 191 & 186 & 30 & -14 \\
\hline $\begin{array}{l}\text { Std. } \\
\text { Dev. }\end{array}$ & 7 & 7 & 7 & 4 & 11 & 6 & 7 & 6 & 4 & 3 & 7 \\
\hline $\begin{array}{c}\text { ULI } \\
\text { M } \\
95 \%\end{array}$ & 183 & 131 & 146 & 7 & 79 & 52 & 188 & 197 & 189 & 33 & -7 \\
\hline $\begin{array}{c}\text { LLIM } \\
95 \%\end{array}$ & 170 & 116 & 133 & 1 & 57 & 40 & 173 & 186 & 182 & 27 & -21 \\
\hline $\begin{array}{c}95 \% \\
\text { CI }\end{array}$ & 14 & 15 & 13 & 7 & 21 & 13 & 15 & 11 & 7 & 6 & 14 \\
\hline
\end{tabular}

\section{Stage 1 and Stage 2 Loading at $4 \mathrm{~g} / \mathrm{L}$}

Table D.3 NO, $\mathrm{NO}_{2}, \mathrm{NO}_{\mathrm{x}}$ concentration at upstream and downstream locations of DOC and $\mathrm{SCRF}^{\circledR}$ during $\mathrm{Stage}$ 1 loading at $4 \mathrm{~g} / \mathrm{L}$

\begin{tabular}{|c|c|c|c|c|c|c|c|c|c|c|c|}
\hline \multirow[b]{2}{*}{$\begin{array}{l}\text { Test } \\
\text { Point }\end{array}$} & \multicolumn{3}{|c|}{ NO } & \multicolumn{3}{|c|}{$\mathrm{NO}_{2}$} & \multicolumn{3}{|c|}{$\mathrm{NO}_{\mathrm{x}}$} & \multicolumn{2}{|c|}{ NO Conv. \% } \\
\hline & $\begin{array}{c}\text { U } \\
\text { DOC }\end{array}$ & $\begin{array}{c}\mathrm{U} \\
\text { SCRF }^{\circledR}\end{array}$ & $\begin{array}{c}\mathrm{D} \\
\mathrm{SCRF}^{\otimes}\end{array}$ & $\begin{array}{c}\text { U } \\
\text { DOC }\end{array}$ & $\begin{array}{c}\mathrm{U} \\
\mathrm{SCRF}^{\otimes}\end{array}$ & $\begin{array}{c}\mathrm{D} \\
\text { SCRF }^{\circledR}\end{array}$ & $\begin{array}{c}\text { U } \\
\text { DOC }\end{array}$ & $\begin{array}{c}\mathrm{U} \\
\text { SCRF }^{\circledR}\end{array}$ & $\begin{array}{c}\text { D } \\
\text { SCRF }\end{array}$ & DOC & $\mathrm{SCRF}^{\circledR}$ \\
\hline$[-]$ & [ppm] & [ppm] & [ppm] & [ppm] & [ppm] & [ppm] & [ppm] & [ppm] & [ppm] & [\%] & [\%] \\
\hline 1 & 147 & 112 & 112 & 1 & 42 & 32 & 148 & 154 & 144 & 24 & 0 \\
\hline 3 & 138 & 98 & 104 & 0 & 46 & 35 & 138 & 144 & 139 & 29 & -6 \\
\hline 6 & 125 & 101 & 117 & 22 & 46 & 31 & 147 & 147 & 149 & 19 & -16 \\
\hline 8 & 130 & 107 & 114 & 18 & 50 & 34 & 148 & 157 & 148 & 18 & -7 \\
\hline Mean & 135 & 105 & 112 & 10 & 46 & 33 & 145 & 151 & 145 & 22 & -7 \\
\hline $\begin{array}{l}\text { Std. } \\
\text { Dev. }\end{array}$ & 10 & 6 & 6 & 11 & 3 & 2 & 5 & 6 & 4 & 5 & 7 \\
\hline $\begin{array}{c}\text { ULI } \\
\text { M } \\
95 \%\end{array}$ & 144 & 111 & 117 & 22 & 49 & 35 & 150 & 157 & 149 & 27 & -1 \\
\hline $\begin{array}{c}\text { LLIM } \\
95 \%\end{array}$ & 125 & 99 & 107 & -1 & 43 & 32 & 140 & 145 & 141 & 17 & -14 \\
\hline $\begin{array}{c}95 \% \\
\text { CI }\end{array}$ & 19 & 12 & 11 & 23 & 6 & 3 & 10 & 12 & 9 & 10 & 13 \\
\hline
\end{tabular}


Table D.4 NO, $\mathrm{NO}_{2}, \mathrm{NO}_{\mathrm{x}}$ concentration at upstream and downstream locations of DOC and $\mathrm{SCRF}^{\circledR}$ during Stage 2 loading at $4 \mathrm{~g} / \mathrm{L}$

\begin{tabular}{|c|c|c|c|c|c|c|c|c|c|c|c|}
\hline \multirow[b]{2}{*}{$\begin{array}{c}\text { Test } \\
\text { Point }\end{array}$} & \multicolumn{3}{|c|}{ NO } & \multicolumn{3}{|c|}{$\mathrm{NO}_{2}$} & \multicolumn{3}{|c|}{$\mathrm{NO}_{\mathrm{x}}$} & \multicolumn{2}{|c|}{ NO Conv. $\%$} \\
\hline & $\begin{array}{c}\text { U } \\
\text { DOC }\end{array}$ & $\begin{array}{c}\mathrm{U} \\
\mathrm{SCRF}^{\otimes}\end{array}$ & $\begin{array}{c}\text { D } \\
\text { SCRF }^{\otimes}\end{array}$ & $\begin{array}{c}\mathrm{U} \\
\mathrm{DOC}\end{array}$ & $\begin{array}{c}\mathrm{U} \\
\mathrm{SCRF}^{\otimes}\end{array}$ & $\begin{array}{c}\mathrm{D} \\
\text { SCRF }^{\otimes}\end{array}$ & $\begin{array}{c}\text { U } \\
\text { DOC }\end{array}$ & $\begin{array}{c}\mathrm{U} \\
\mathrm{SCRF}^{\otimes}\end{array}$ & $\begin{array}{c}\text { D } \\
\text { SCRF }^{\otimes}\end{array}$ & DOC & SCRF $^{\circledast}$ \\
\hline$[-]$ & $\underset{]}{[p p m}$ & [ppm] & [ppm] & [ppm] & [ppm] & [ppm] & [ppm] & [ppm] & [ppm] & [\%] & [\%] \\
\hline 1 & 133 & 110 & 135 & 18 & 53 & 17 & 152 & 163 & 152 & 17 & -22 \\
\hline 3 & 145 & 100 & 118 & 2 & 53 & 25 & 147 & 153 & 143 & 31 & -18 \\
\hline 6 & 147 & 122 & 156 & 23 & 54 & 23 & 170 & 175 & 179 & 17 & -29 \\
\hline 8 & 135 & 102 & 132 & 17 & 48 & 18 & 152 & 150 & 150 & 24 & -29 \\
\hline Mean & 140 & 109 & 135 & 15 & 52 & 21 & 155 & 161 & 156 & 23 & -24 \\
\hline $\begin{array}{l}\text { Std. } \\
\text { Dev. }\end{array}$ & 7 & 10 & 16 & 9 & 3 & 4 & 10 & 11 & 16 & 6 & 6 \\
\hline $\begin{array}{c}\text { ULIM } \\
\mathbf{9 5 \%}\end{array}$ & 147 & 118 & 151 & 24 & 55 & 24 & 165 & 172 & 172 & 29 & -19 \\
\hline $\begin{array}{l}\text { LLIM } \\
95 \%\end{array}$ & 133 & 99 & 120 & 6 & 49 & 17 & 145 & 149 & 140 & 16 & -30 \\
\hline $95 \% \mathrm{CI}$ & 14 & 19 & 31 & 18 & 5 & 7 & 20 & 22 & 31 & 12 & 11 \\
\hline
\end{tabular}

\section{$\mathrm{NO}_{\mathrm{x}}$ Reduction Stage}

Table D.5 Species concentration at upstream and downstream $\mathrm{SCRF}^{\circledR}$ for $\mathrm{NO}_{\mathrm{x}}$ reduction test points at ANR-0

\begin{tabular}{|c|c|c|c|c|c|c|c|c|c|c|c|c|}
\hline \multirow{3}{*}{$\begin{array}{l}\text { Test } \\
\text { Point }\end{array}$} & \multicolumn{6}{|c|}{ NO [ppm] } & \multicolumn{6}{|c|}{$\mathrm{NO}_{2}[\mathrm{ppm}]$} \\
\hline & \multicolumn{2}{|c|}{$\mathrm{SCRF}^{\circledR-} 0$} & \multicolumn{2}{|c|}{$\mathrm{SCRF}^{\circledR-2}$} & \multicolumn{2}{|c|}{ SCRF $^{\circledR-~} 4$} & \multicolumn{2}{|c|}{$\mathrm{SCRF}^{\circledR-} 0$} & \multicolumn{2}{|c|}{$\mathrm{SCRF}^{\circledR-2}$} & \multicolumn{2}{|c|}{ SCRF $^{\circledR-~} 4$} \\
\hline & In & Out & In & Out & In & Out & In & Out & In & Out & In & Out \\
\hline 1 & 345 & 352 & 403 & 387 & 453 & 402 & 213 & 200 & 203 & 205 & 146 & 115 \\
\hline 3 & 158 & 160 & 161 & 198 & 198 & 249 & 121 & 116 & 131 & 88 & 124 & 75 \\
\hline 6 & 795 & 808 & 743 & 967 & 793 & 1151 & 674 & 688 & 644 & 426 & 588 & 231 \\
\hline 8 & 411 & 415 & 424 & 457 & 415 & 502 & 140 & 139 & 125 & 52 & 115 & 22 \\
\hline
\end{tabular}


Table D.6 Species concentration at upstream and downstream $\mathrm{SCRF}^{\circledR}$ for $\mathrm{NO}_{\mathrm{x}}$ reduction test points at ANR-1.2 Rpt.

\begin{tabular}{|c|c|c|c|c|c|c|c|c|c|c|c|c|c|c|c|c|c|c|}
\hline \multirow{3}{*}{$\begin{array}{l}\text { Test } \\
\text { Point }\end{array}$} & \multicolumn{6}{|c|}{ NO [ppm] } & \multicolumn{6}{|c|}{$\mathrm{NO}_{2}$ [ppm] } & \multicolumn{6}{|c|}{$\mathrm{NH}_{3}$ [ppm] } \\
\hline & \multicolumn{2}{|c|}{ SCRF $^{\circledR-~} 0$} & \multicolumn{2}{|c|}{ SCRF $^{\circledR-2}$} & \multicolumn{2}{|c|}{ SCRF $^{\circledR-} 4$} & \multicolumn{2}{|c|}{$\mathrm{SCRF}^{\circledR-} 0$} & \multicolumn{2}{|c|}{$\mathrm{SCRF}^{\circledR-2}$} & \multicolumn{2}{|c|}{ SCRF $^{\circledR-4}$} & \multicolumn{2}{|c|}{ SCRF $^{\circledR-0}$} & \multicolumn{2}{|c|}{$\mathrm{SCRF}^{\circledR-2}$} & \multicolumn{2}{|c|}{ SCRF $^{\circledR-4}$} \\
\hline & In & Out & In & Out & In & Out & In & Out & In & Out & In & Out & In & Out & In & Out & In & Out \\
\hline 1 & 345 & 7 & 403 & 8 & 453 & 15 & 213 & 0 & 203 & 0 & 146 & 1 & 685 & 117 & 723 & 120 & 722 & 148 \\
\hline 3 & 158 & 5 & 161 & 2 & 198 & 3 & 121 & 0 & 131 & 0 & 124 & 0 & 331 & 61 & 347 & 48 & 392 & 62 \\
\hline 6 & 795 & 5 & 743 & 6 & 793 & 9 & 674 & 0 & 644 & 0 & 588 & 1 & 1685 & 208 & 1644 & 105 & 1596 & 124 \\
\hline 8 & 411 & 35 & 424 & 40 & 415 & 75 & 140 & 0 & 125 & 0 & 115 & 0 & 657 & 85 & 646 & 33 & 642 & 121 \\
\hline
\end{tabular}

Table D.7 Species conversion efficiency across $\mathrm{SCRF}^{\circledR}$ for $\mathrm{NO}_{\mathrm{x}}$ reduction test points at ANR-1.2 Rpt.

\begin{tabular}{|c|c|c|c|c|c|c|c|c|c|}
\hline \multirow{2}{*}{ Test Point } & \multicolumn{3}{|c|}{ ANR } & \multicolumn{3}{|c|}{$\mathrm{NO}_{\mathrm{x}}$ conversion efficiency [\%] } & \multicolumn{3}{|c|}{ Nitrogen Balance [\%] } \\
\hline & $\mathrm{SCRF}^{\circledR-0} 0$ & $\mathrm{SCRF}^{\circledR-2}$ & $\mathrm{SCRF}^{\mathrm{Q}-} 4$ & SCRF $^{\circledR-} 0$ & SCRF $^{\circledR-2}$ & SCRF $^{\circledR-4}$ & SCRF $^{\circledR-0}$ & SCRF $^{\circledR-2}$ & SCRF $^{\circledR-4}$ \\
\hline 1 & 1.23 & 1.19 & 1.21 & 99 & 99 & 97 & 97 & 99 & 101 \\
\hline 3 & 1.19 & 1.19 & 1.22 & 98 & 99 & 99 & 101 & 97 & 97 \\
\hline 6 & 1.15 & 1.19 & 1.16 & 100 & 100 & 99 & 99 & 90 & 94 \\
\hline 8 & 1.19 & 1.18 & 1.21 & 94 & 93 & 86 & 91 & 84 & 90 \\
\hline
\end{tabular}

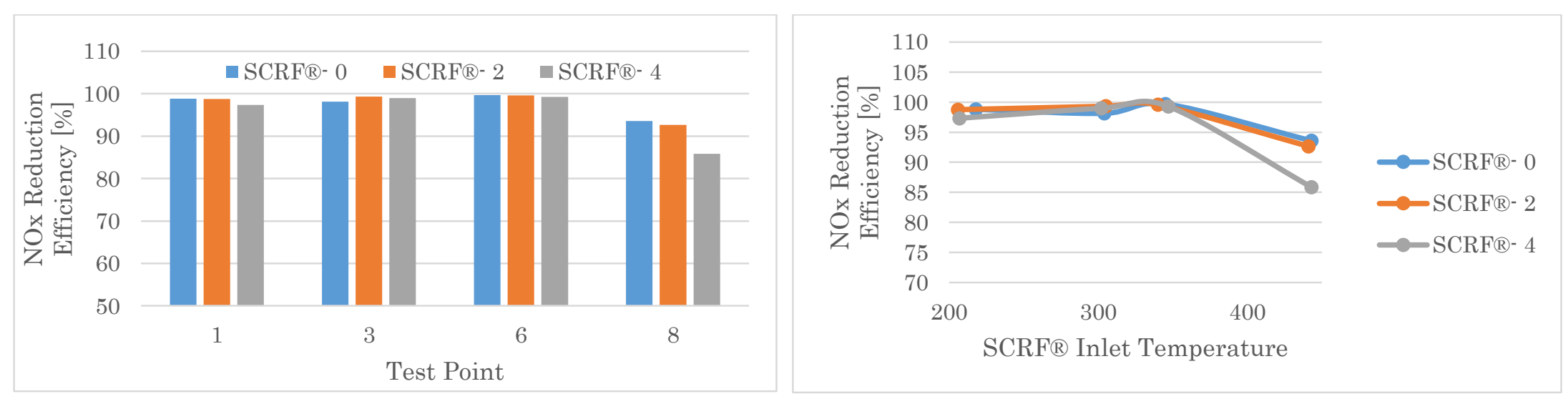

Figure D.1 NO $\mathrm{x}$ conversion efficiency (\%) with ANR - 1.2 Repeat for test points with and without loading 


\section{Appendix E. SCRF ${ }^{\circledR}$ Pressure Drops}

The pressure drops across the $\mathrm{SCRF}^{\circledR}$ for each test point with and without PM loading are presented in this section in the figures. The pressure drop curve for tests with $0 \mathrm{~g} / \mathrm{L}$ PM loading is constant because the PM concentration coming into the $\mathrm{SCRF}^{\circledR}$ is low as shown in Figures E.1, E.2, E.3, and E.4.

The test points 6 and 8 have higher PM oxidation rate because of higher SCRF ${ }^{\circledR}$ inlet temperatures and, therefore the $\mathrm{SCRF}^{\circledR}$ was loaded again in between the $\mathrm{NO}_{\mathrm{x}}$ reduction stage which is denoted by repeat loadings, as shown in Figures E.7 and E. 8 for $2 \mathrm{~g} / \mathrm{L}$ loading. Similar repeat loading was done for the same test points for 4 g/L as shown in Figures E.11 and E.12. In Figures E.5, E.6, E.9, and E.10, the PM oxidation is low and hence repeated loading was not required.

\section{Loading at $0 \mathrm{~g} / \mathrm{L}$}

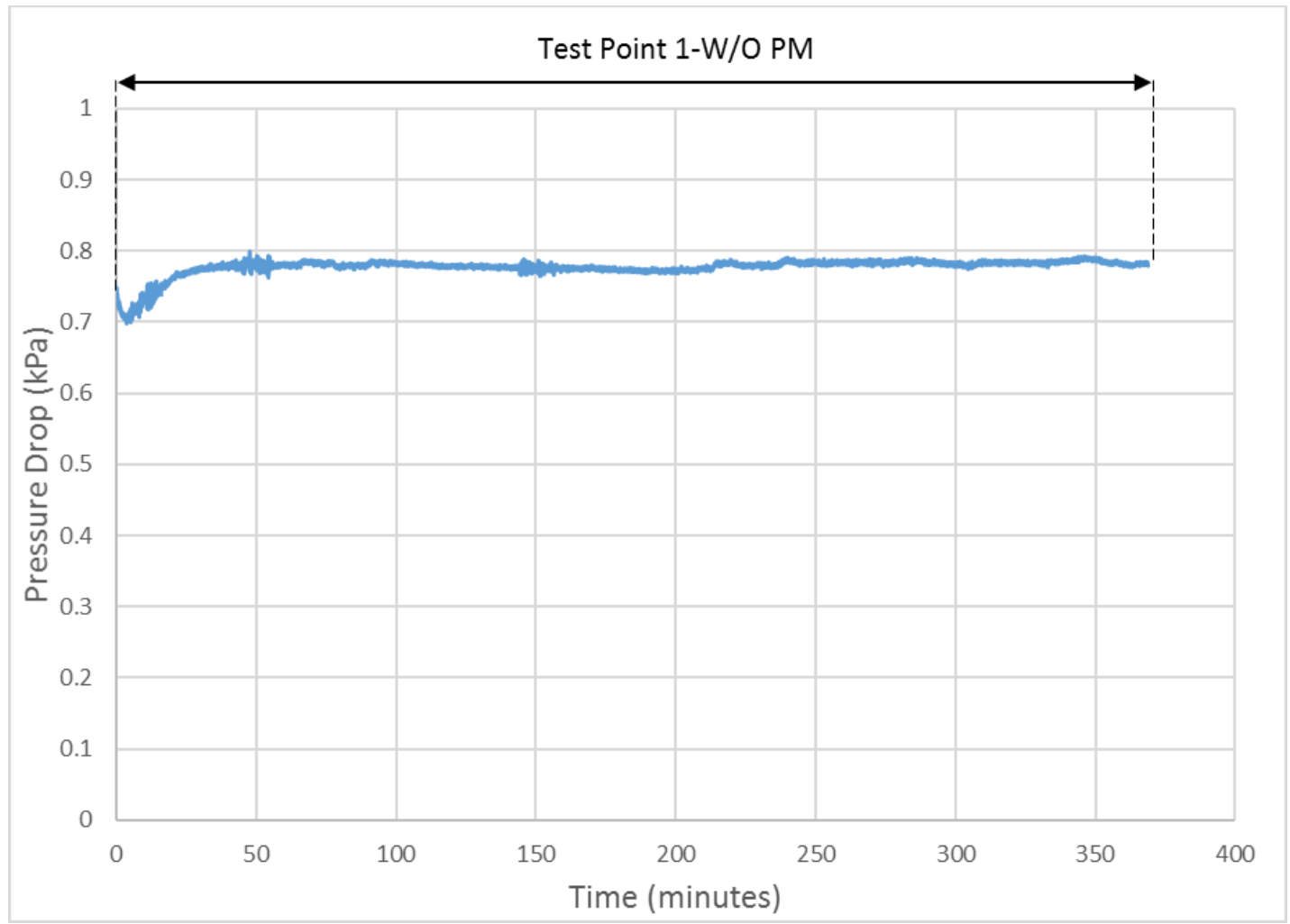

Figure E.1 Pressure drop curve for test point 1 without PM loading in the SCRF ${ }^{\circledR}$ 


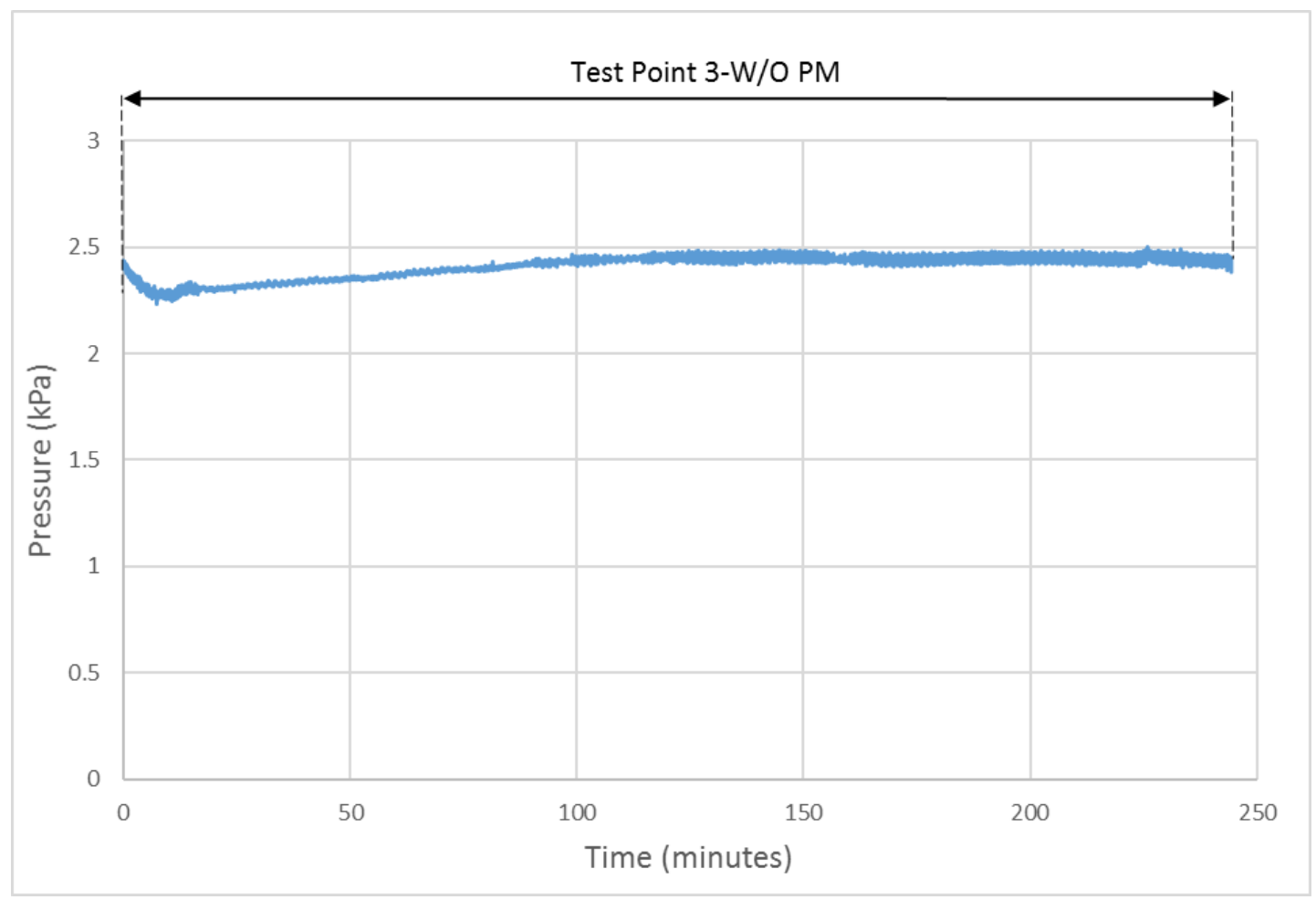

Figure E.2 Pressure drop curve for test point 3 without PM loading in the $\mathrm{SCRF}^{\circledR}$

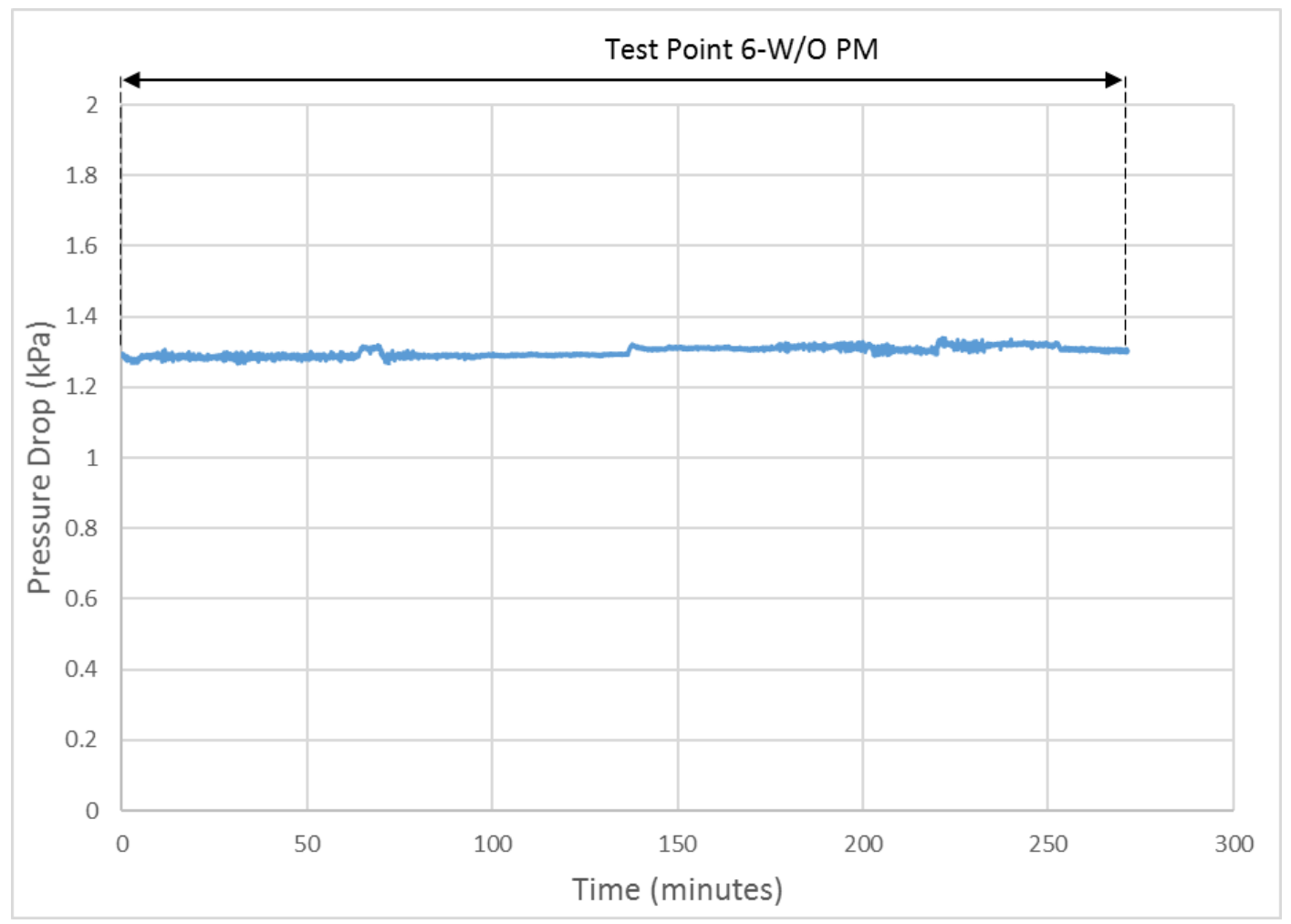

Figure E.3 Pressure drop curve for test point 6 without PM loading in the SCRF $^{\circledR}$ 


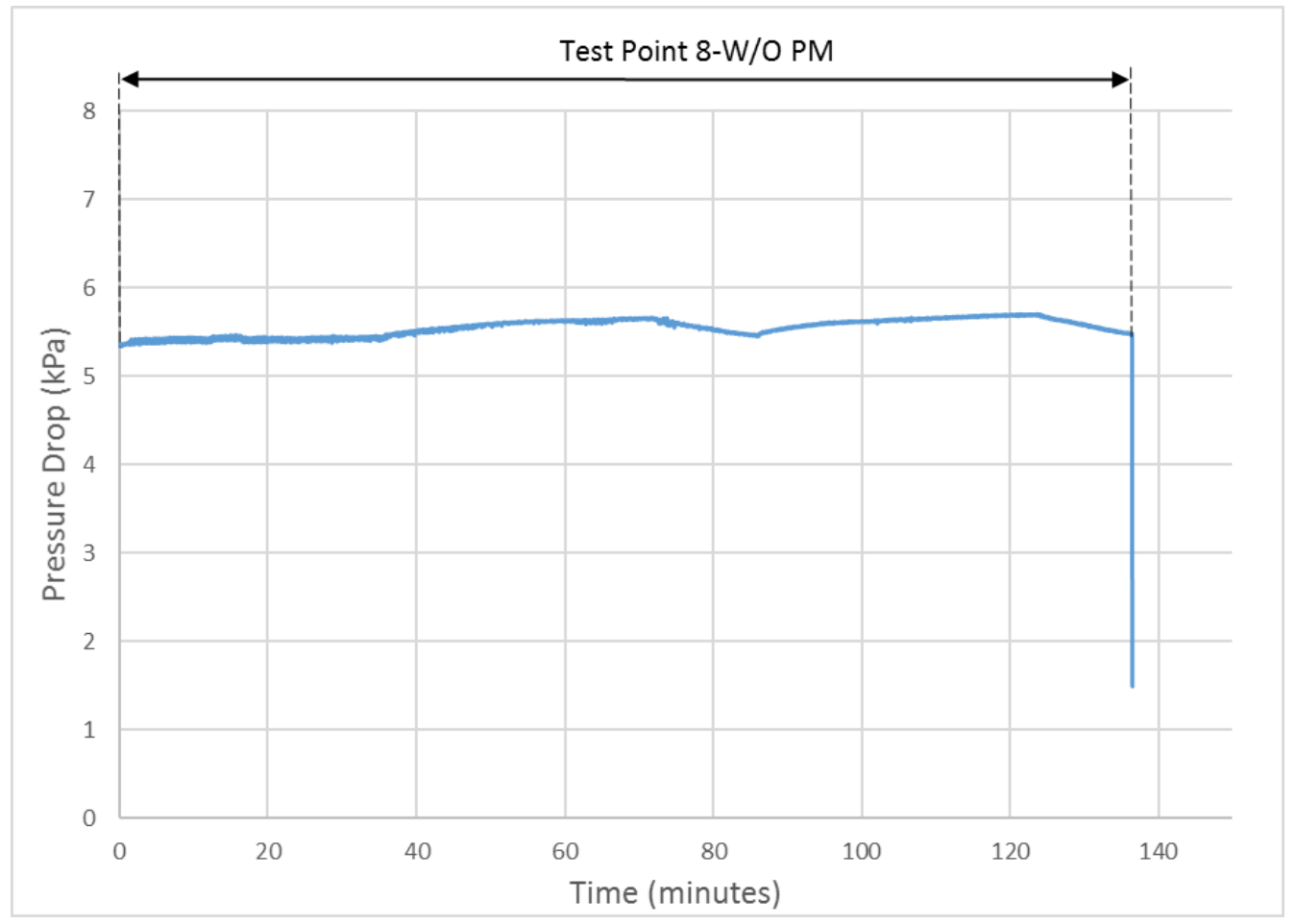

Figure E.4 Pressure drop curve for test point 8 without PM loading in the SCRF $^{\circledR}$

\section{Loading at $2 \mathrm{~g} / \mathrm{L}$}

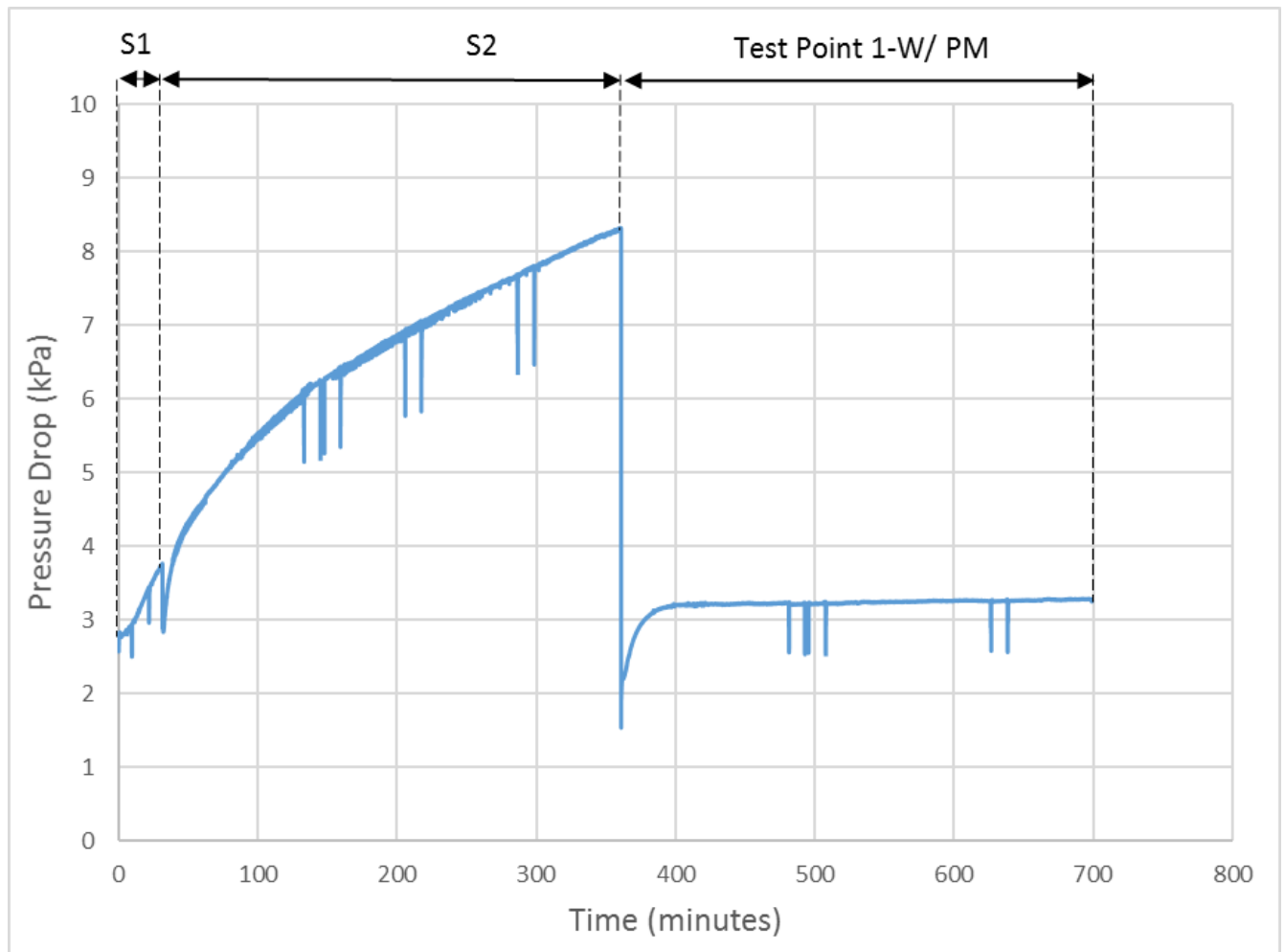

Figure E.5 Pressure drop curve for test point 1 with PM loading $2 \mathrm{~g} / \mathrm{L}$ in the $\mathrm{SCRF}^{\circledR}$ 


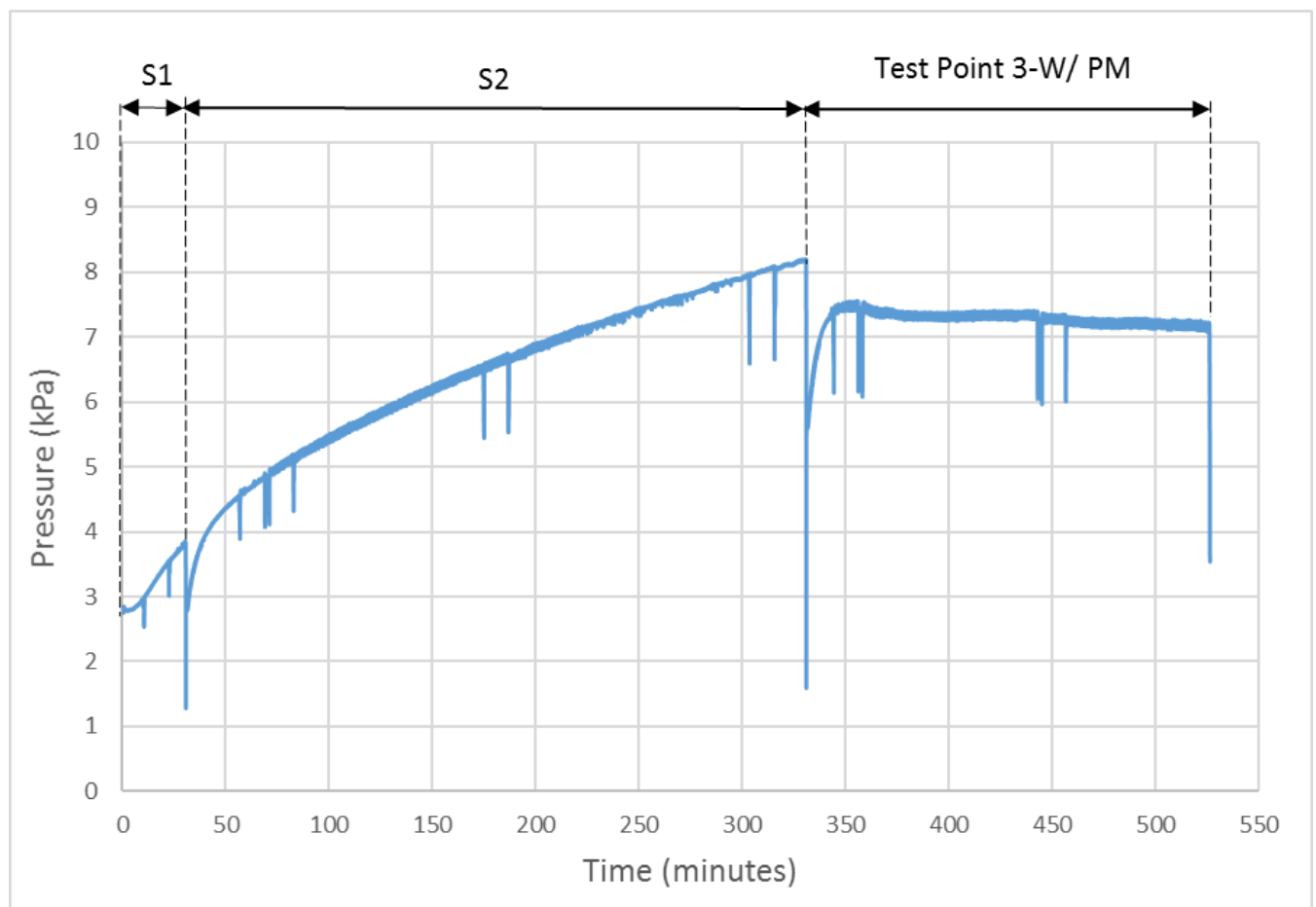

Figure E.6 Pressure drop curve for test point 3 with PM loading 2 g/L in the $\mathrm{SCRF}^{\circledR}$

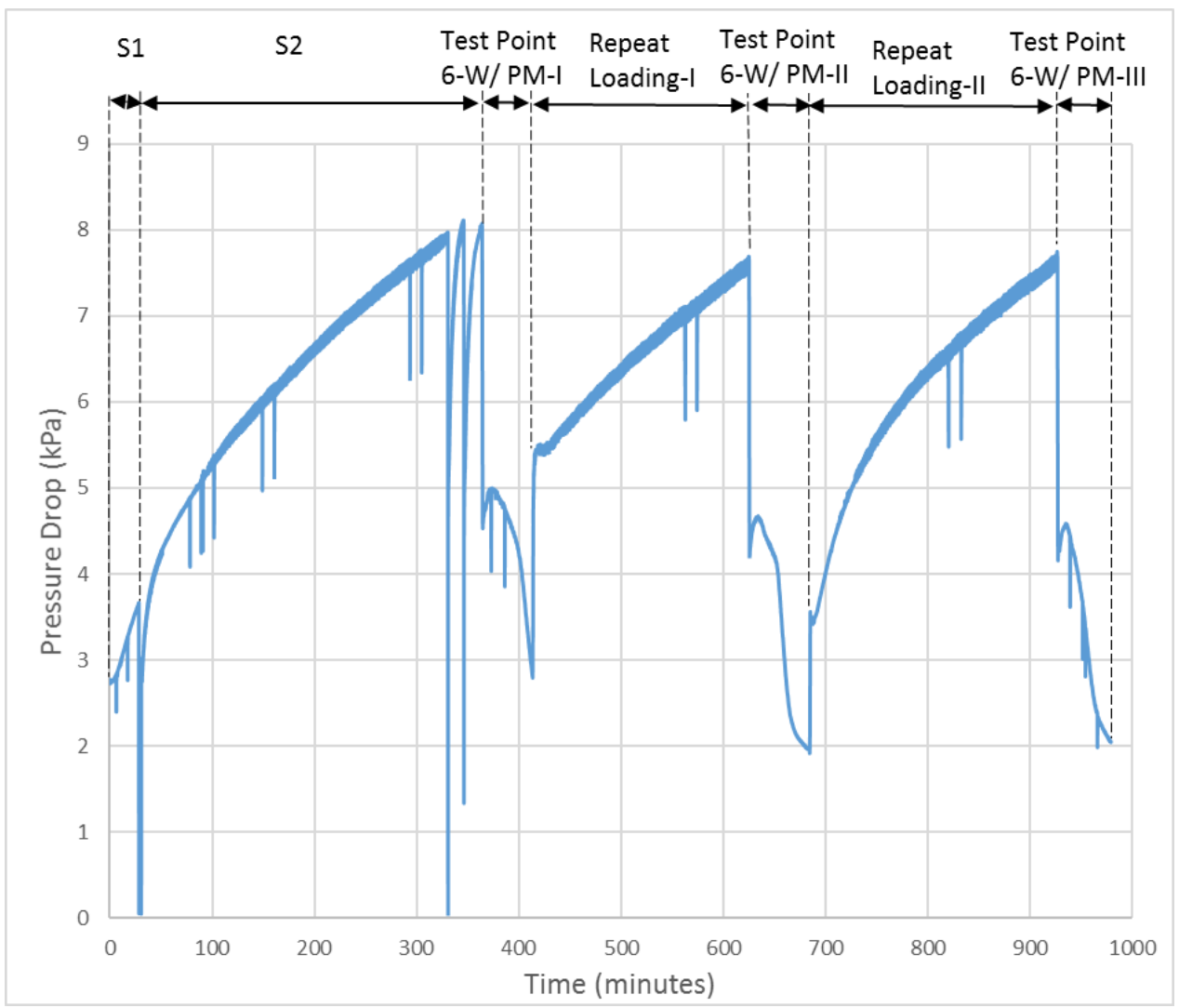

Figure E.7 Pressure drop curve for test point 6 with PM loading 2 g/L in the $\mathrm{SCRF}^{\circledR}$ 


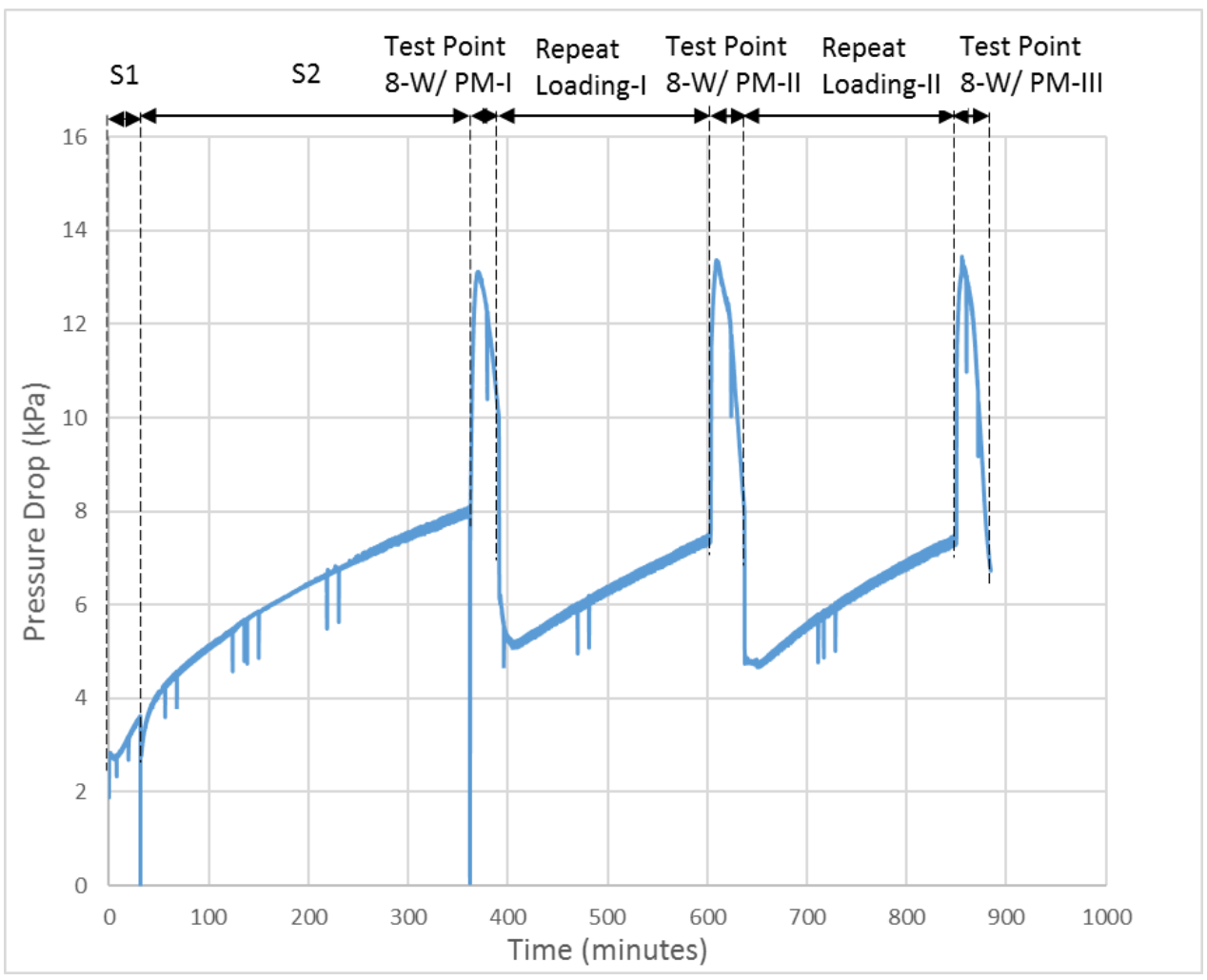

Figure E. 8 Pressure drop curve for test point 8 with PM loading 2 g/L in the SCRF ${ }^{\circledR}$

\section{Loading at $4 \mathrm{~g} / \mathrm{L}$}

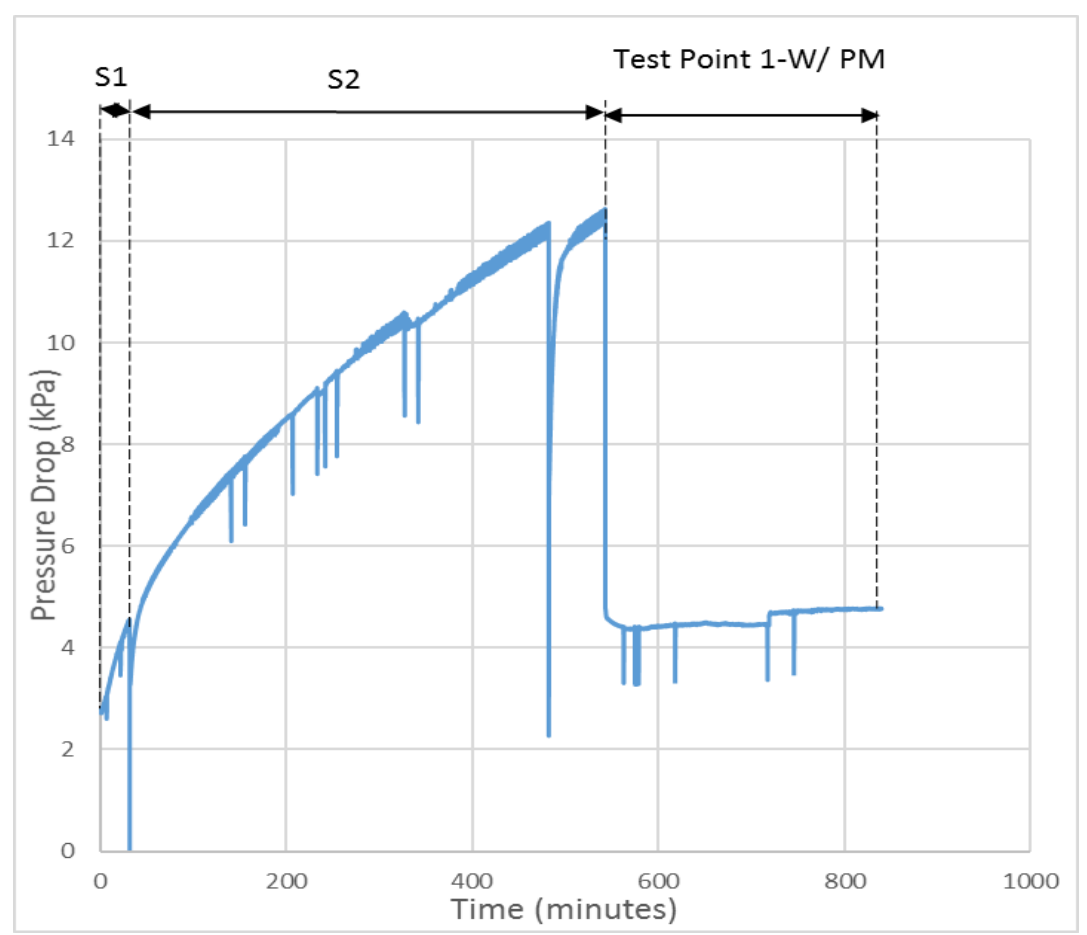

Figure E.9 Pressure drop curve for test point 1 with PM loading 4 g/L in the $\mathrm{SCRF}^{\circledR}$ 


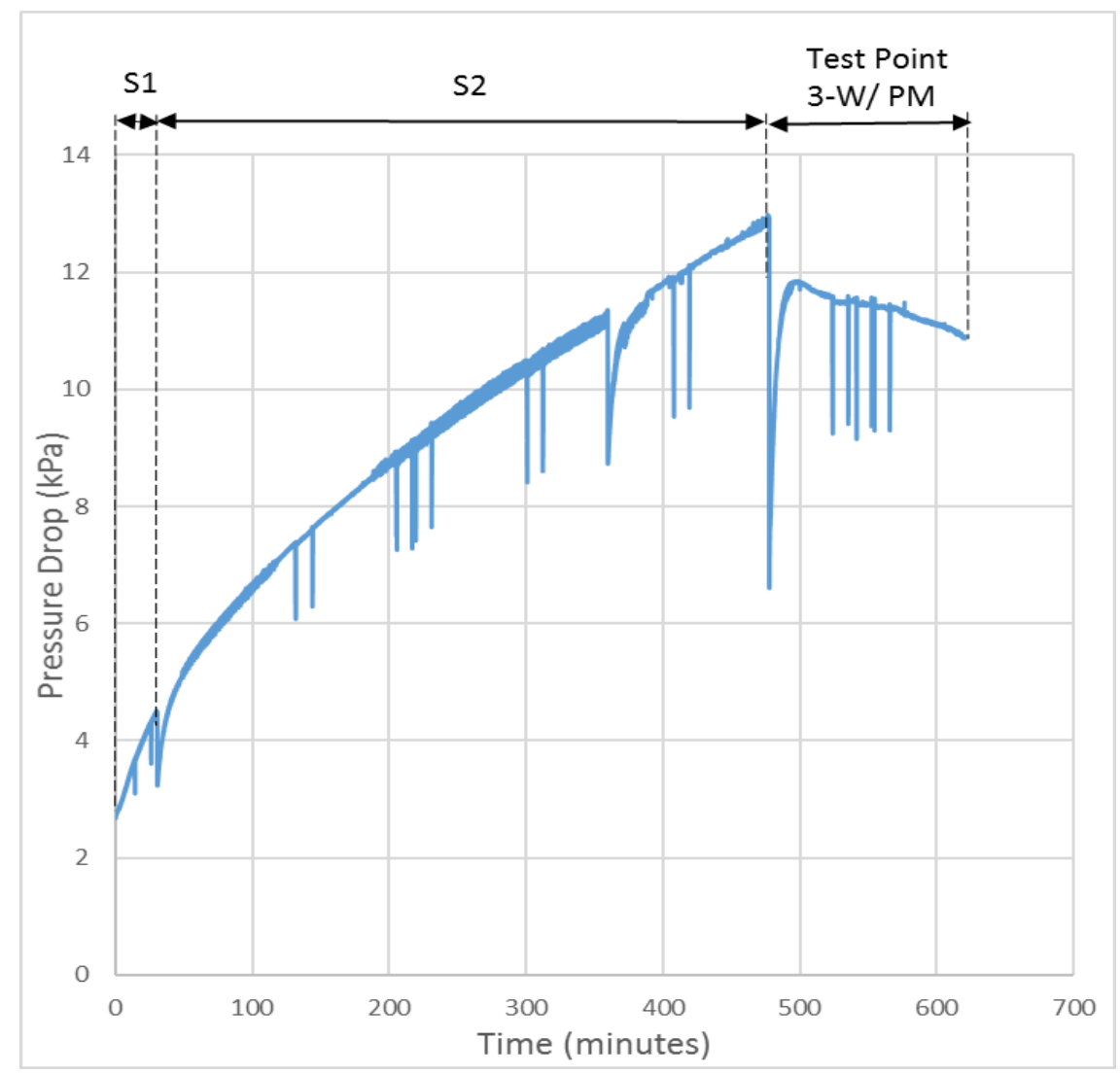

Figure E.10 Pressure drop curve for test point 3 with PM loading $4 \mathrm{~g} / \mathrm{L}$ in the SCRF ${ }^{\circledR}$

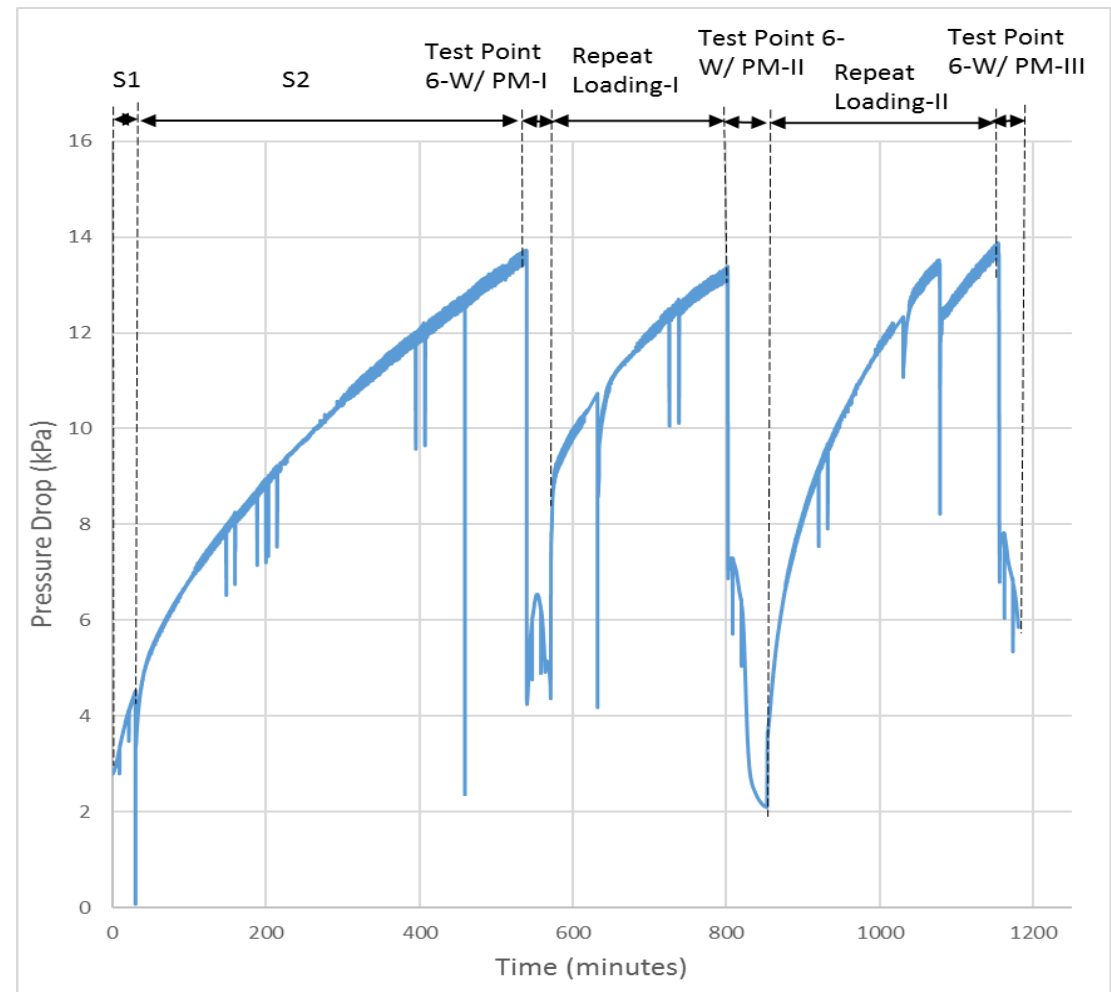

Figure E.11 Pressure drop curve for test point 6 with PM loading $4 \mathrm{~g} / \mathrm{L}$ in the $\mathrm{SCRF}^{\circledR}$ 


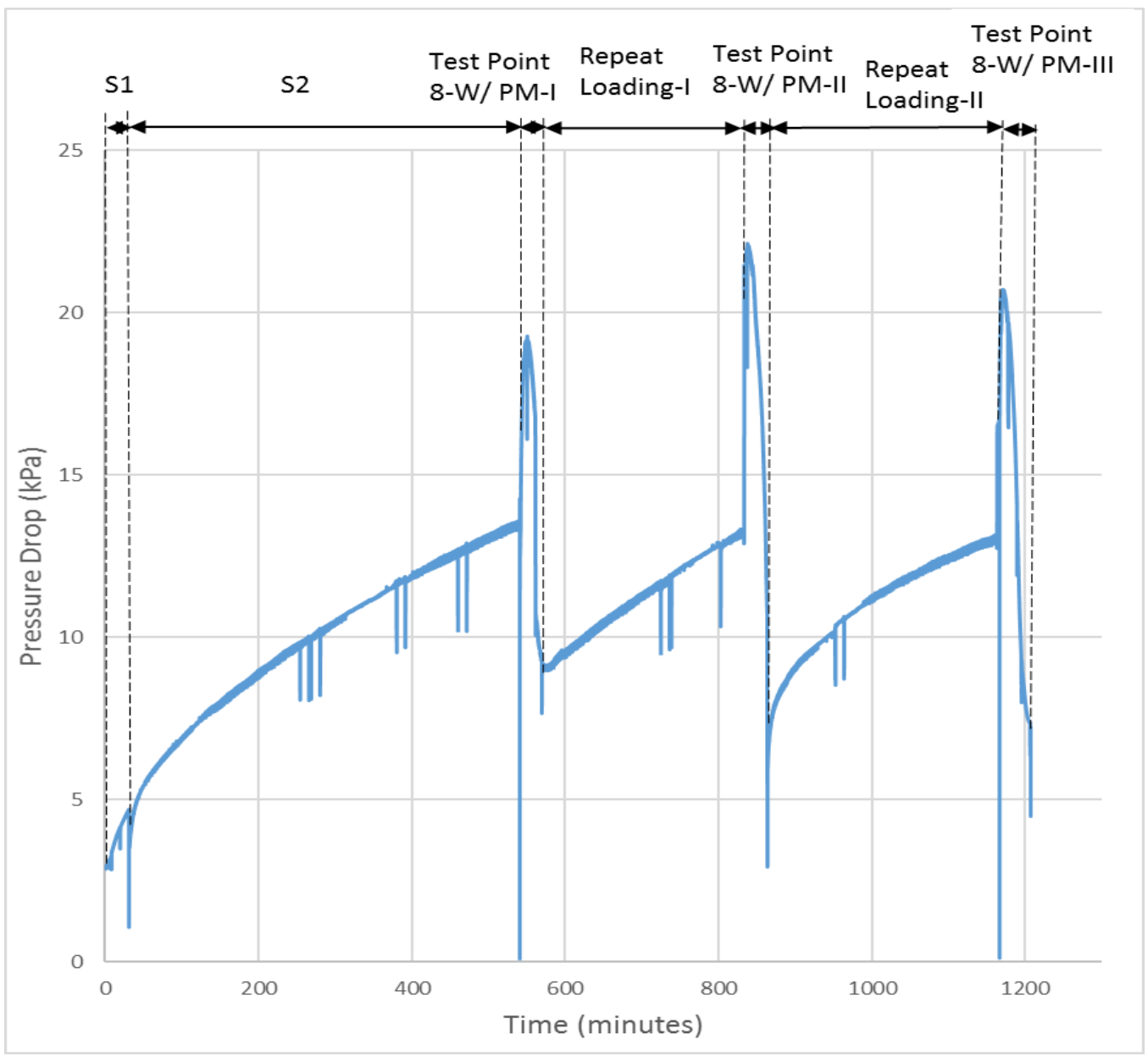

Figure E.12 Pressure drop curve for test point 8 with PM loading 4 g/L in the SCRF ${ }^{\circledR}$ 


\section{Appendix F. SCRF ${ }^{\circledR}$ Temperature Distributions}

In this appendix, the temperature distribution in the radial and axial positions in the $\mathrm{SCRF}^{\circledR}$ is presented. The study of temperature distribution is critical to calibrate the model being developed at MTU. Figure F-1 shows the K-type thermocouple positions in the $\mathrm{SCRF}^{\circledR}$ at specific radial and axial locations. The thermocouples were placed to measure gas temperature at four axial locations (at a distance of 32, 152, 207 and 273 $\mathrm{mm}$, from the inlet end of the $\mathrm{SCRF}^{\circledR}$ ) and five radial locations (at a distance of 0,55 , 95, 122, and $131 \mathrm{~mm}$ from the center of the $\mathrm{SCRF}^{\circledR}$ block).

The temperature in the $\mathrm{SCRF}^{\circledR}$ is monitored at loading and $\mathrm{NO}_{\mathrm{x}}$ reduction stages, with or without PM loading in the $\mathrm{SCRF}^{\circledR}$. The 20 thermocouples labeled from $\mathrm{S} 1$ to $\mathrm{S} 20$ with their axial and radial positions were used to plot the temperature profiles. Thermocouples S1 to S5 and S16 to S20 are located in radial positions at the inlet and outlet of the $\mathrm{SCRF}^{\circledR}$ respectively. The radially varying temperature is attributed to external ambient heat transfer from the filter and the axially varying temperature is attributed to $\mathrm{PM}$ oxidation in the $\mathrm{SCRF}^{\circledR}$ along with heat flow distribution in radial and axial direction.

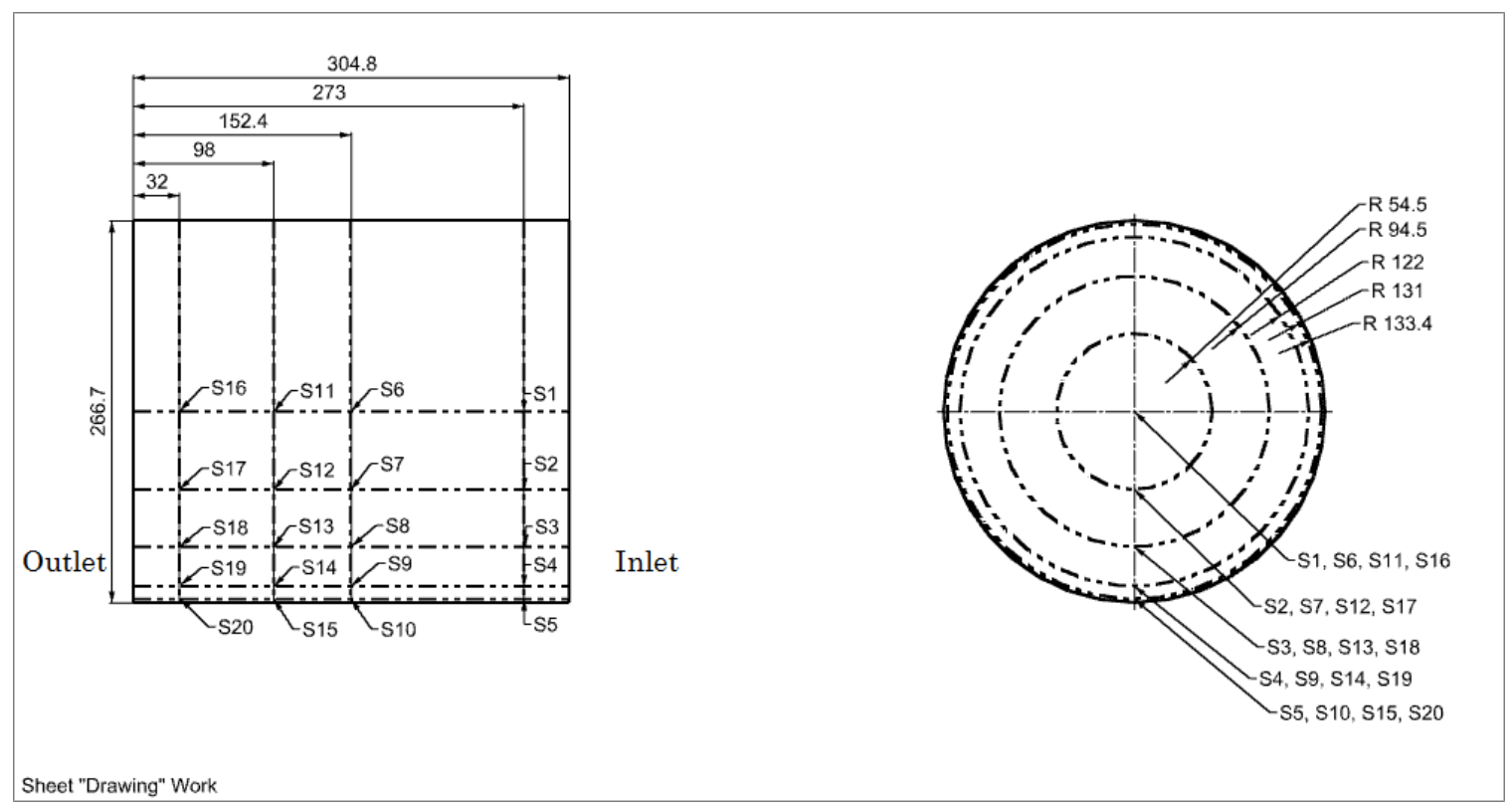

Figure F.1 Thermocouple arrangement for the $\mathrm{SCRF}^{\circledR}$ - dimensions in mm 
Stage 2 Loading at $2 \mathrm{~g} / \mathrm{L}$ and $4 \mathrm{~g} / \mathrm{L}$

Figures show the temperature boundary layer at the $\mathrm{SCRF}^{\circledR}$ inlet and temperature distribution in the complete $\mathrm{SCRF}^{\circledR}$ during Stage 2 loading for test point 1, 3, 6, and 8. The time (in hrs.) from the start of experiment at which the temperature distribution is plotted during Stage 2 loading is shown in Tables F.1 and F.2. It is observed from the temperature distribution plots that the temperatures are consistent along the axial locations of the $\mathrm{SCRF}^{\circledR}$. A slight drop in temperature has been observed for $4 \mathrm{~g} / \mathrm{L}$ tests along the axial position, in Figures F.16, F.17, F.18, and F.19.

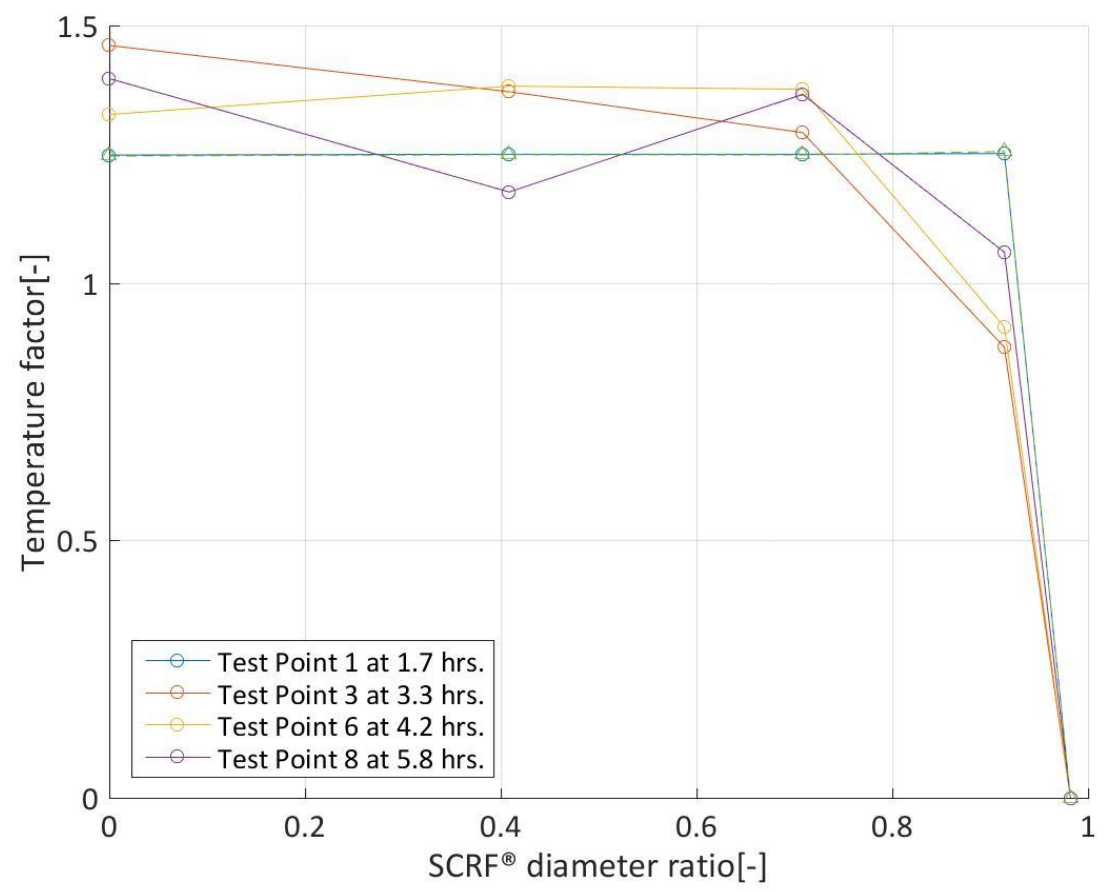

Figure F.2 Temperature boundary layer at SCRF ${ }^{\circledR}$ inlet during Stage 2 loading of 2 g/L. 
Table F.1 Thermocouple temperatures at Stage 2 loading at $2 \mathrm{~g} / \mathrm{L}$

\begin{tabular}{|c|c|c|c|c|c|c|c|c|c|c|c|c|c|c|c|c|c|c|c|c|c|}
\hline \multirow{2}{*}{$\begin{array}{c}\text { Stage } 2 \text { - } \\
2 \mathrm{~g} / \mathrm{L}\end{array}$} & \multirow{2}{*}{$\begin{array}{l}\text { Time } \\
\text { [hr.] }\end{array}$} & \multicolumn{20}{|c|}{ SCRF $^{\circledR}$ Thermocouple Temperature $\left[{ }^{\circ} \mathrm{C}\right]$} \\
\hline & & S1 & S2 & S3 & $\mathrm{S} 4$ & S5 & S6 & S7 & S8 & S9 & S10 & S11 & S12 & S13 & S14 & S15 & S16 & S17 & S18 & S19 & $\mathrm{S} 20$ \\
\hline 1 & 1.7 & $290^{1}$ & 287 & 287 & 285 & $295^{1}$ & 289 & 288 & 287 & $283^{1}$ & 276 & 288 & 288 & 286 & 282 & 268 & 287 & 287 & 287 & 283 & 263 \\
\hline 3 & 3.3 & 282 & 282 & 281 & 279 & $273^{1}$ & 283 & 282 & 280 & $275^{1}$ & 269 & 282 & 281 & 280 & 275 & 261 & 281 & 281 & 281 & 277 & 258 \\
\hline 6 & 4.2 & 283 & 283 & 283 & 279 & 272 & 284 & 284 & 283 & $278^{1}$ & 271 & 283 & $283^{1}$ & $283^{1}$ & 277 & 263 & 282 & 283 & 283 & 278 & 262 \\
\hline 8 & 5.8 & 283 & $282^{1}$ & 283 & 281 & 275 & 285 & 282 & 282 & $280^{1}$ & 271 & $286^{1}$ & 283 & 283 & 279 & 263 & 286 & 283 & 283 & 276 & 261 \\
\hline
\end{tabular}

Table F.2 Thermocouple temperatures at Stage 2 loading at $4 \mathrm{~g} / \mathrm{L}$

\begin{tabular}{|c|c|c|c|c|c|c|c|c|c|c|c|c|c|c|c|c|c|c|c|c|c|}
\hline \multirow{2}{*}{$\begin{array}{c}\text { Stage } 2- \\
4 \mathrm{~g} / \mathrm{L}\end{array}$} & \multirow{2}{*}{$\begin{array}{l}\text { Time } \\
\text { [hr.] }\end{array}$} & \multicolumn{20}{|c|}{ SCRF $^{\circledast}$ Thermocouple Temperature $\left[{ }^{\circ} \mathrm{C}\right]$} \\
\hline & & S1 & S2 & S3 & S4 & S5 & S6 & S7 & S8 & S9 & $\mathrm{S} 10$ & $\mathrm{~S} 11$ & $\mathrm{~S} 12$ & $\mathrm{~S} 13$ & $\mathrm{~S} 14$ & S15 & $\mathrm{S} 16$ & S17 & $\mathrm{S} 18$ & S19 & S20 \\
\hline 1 & 4.4 & $300^{1}$ & 300 & 300 & 297 & 289 & 299 & 300 & 300 & $295^{1}$ & 291 & 299 & 299 & 298 & $294^{1}$ & 279 & 300 & 299 & 299 & 292 & 279 \\
\hline 3 & 5.0 & 297 & 296 & 296 & 294 & 287 & 298 & 298 & 298 & $292^{1}$ & 283 & 297 & 297 & 296 & 291 & 275 & $300^{1}$ & 297 & 296 & $289^{1}$ & 276 \\
\hline 6 & 6.6 & $306^{1}$ & 307 & 305 & 305 & 297 & 306 & 307 & 307 & $302^{1}$ & 297 & 307 & 307 & $307^{1}$ & 301 & 287 & $308^{1}$ & 307 & 307 & 301 & 287 \\
\hline 8 & 6.6 & 308 & $306^{1}$ & 307 & 305 & 299 & 308 & 307 & 308 & $303^{1}$ & $291^{1}$ & 308 & 308 & $308^{1}$ & 302 & 287 & 308 & $308^{1}$ & 308 & 302 & 286 \\
\hline
\end{tabular}

${ }^{1}$ The highlighted thermocouple temperatures have been approximated on the basis of the trend of thermocouple temperatures in other test points. 


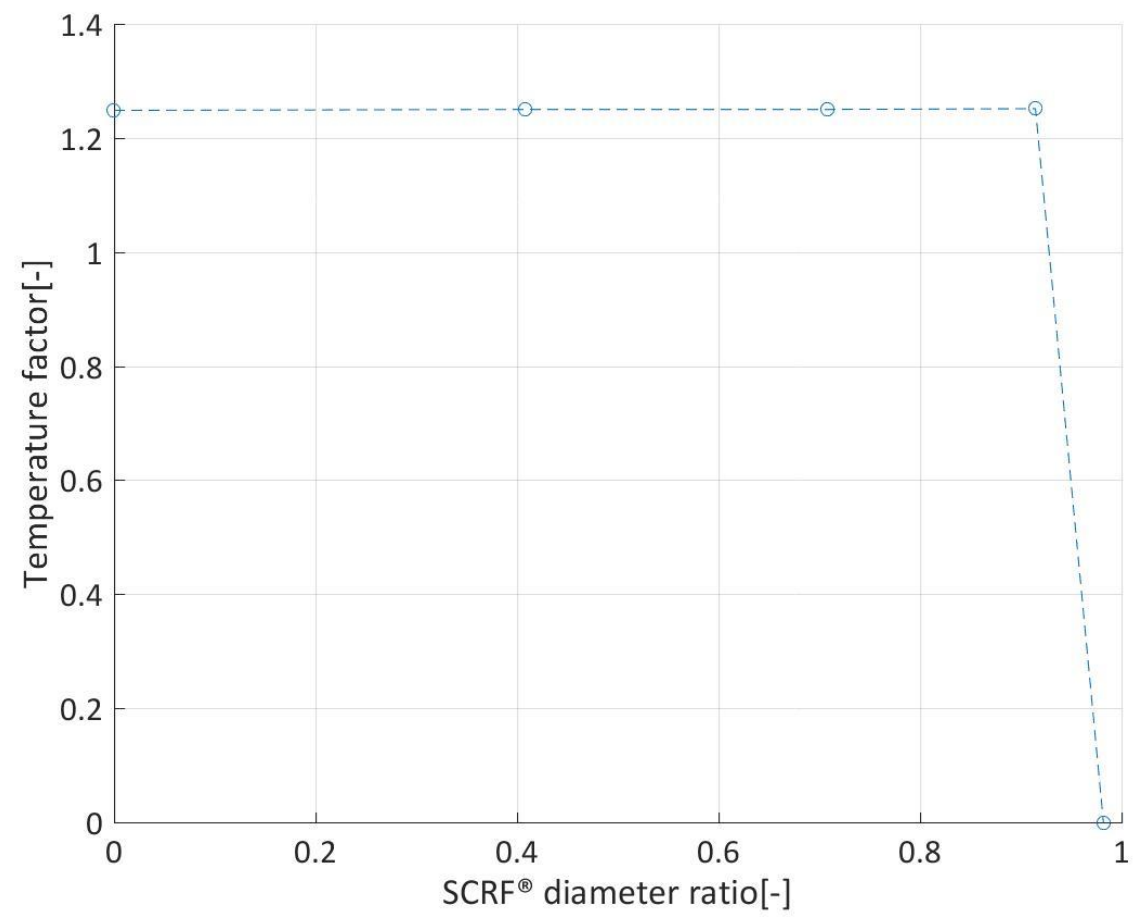

Figure F.3 Temperature boundary layer at $\mathrm{SCRF}^{\circledR}$ inlet at $1.7 \mathrm{hrs}$. for test point 1 during Stage 2 loading of $2 \mathrm{~g} / \mathrm{L}$

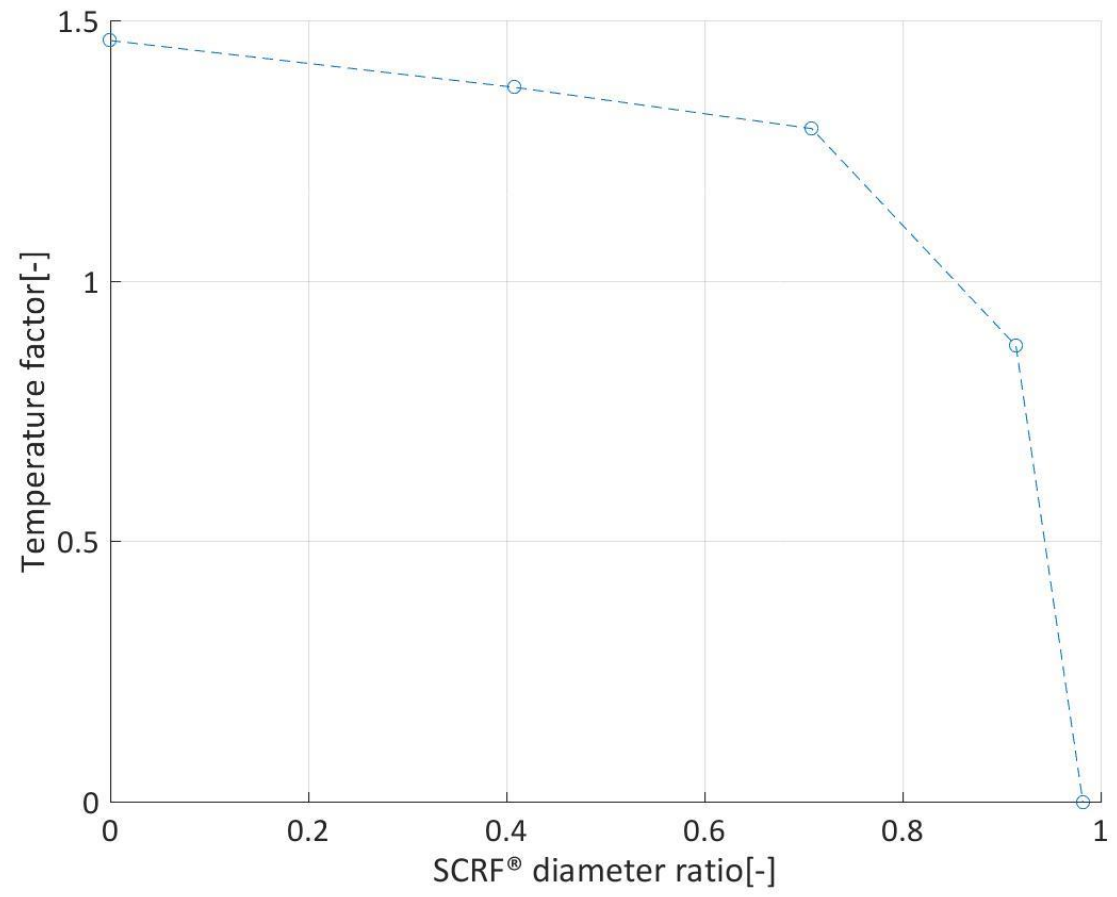

Figure F.4 Temperature boundary layer at $\mathrm{SCRF}^{\circledR}$ inlet at $3.3 \mathrm{hrs}$. for test point 3 during Stage 2 loading of $2 \mathrm{~g} / \mathrm{L}$ 


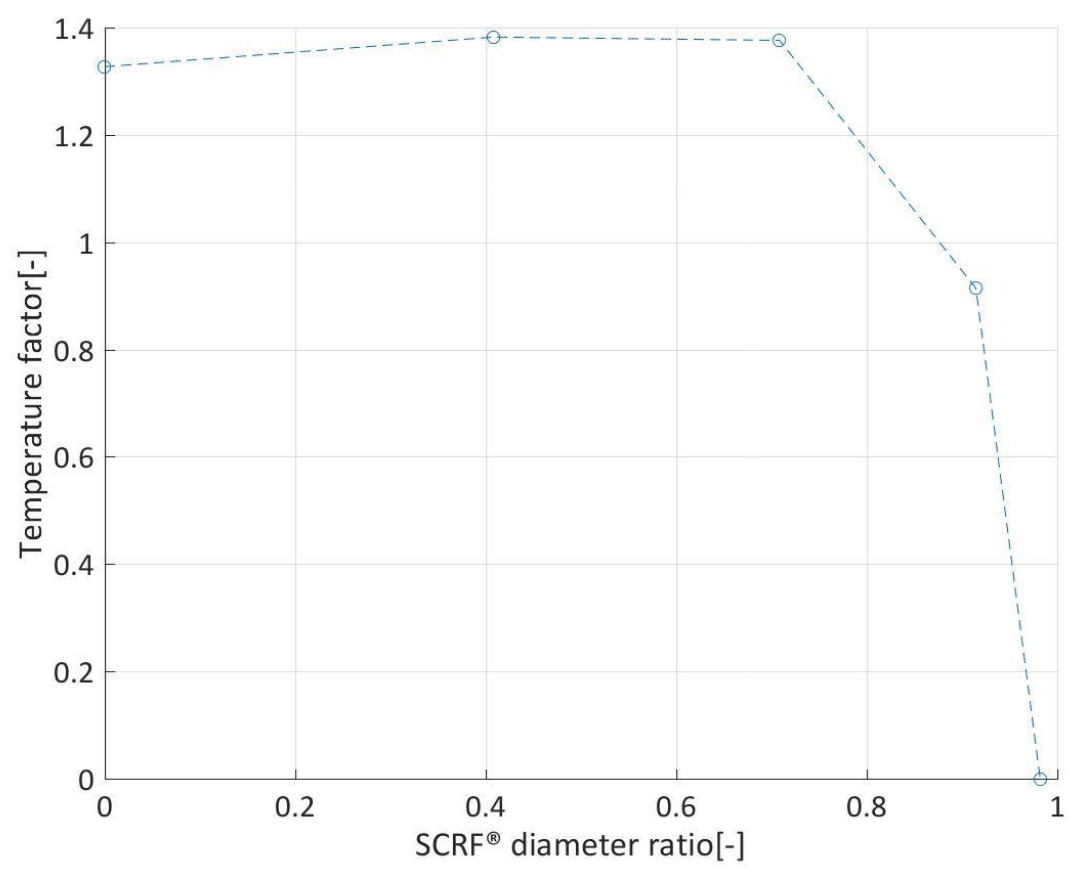

Figure F.5 Temperature boundary layer at $\mathrm{SCRF}^{\circledR}$ inlet at $4.2 \mathrm{hrs}$. for test point 6 during Stage 2 loading of $2 \mathrm{~g} / \mathrm{L}$

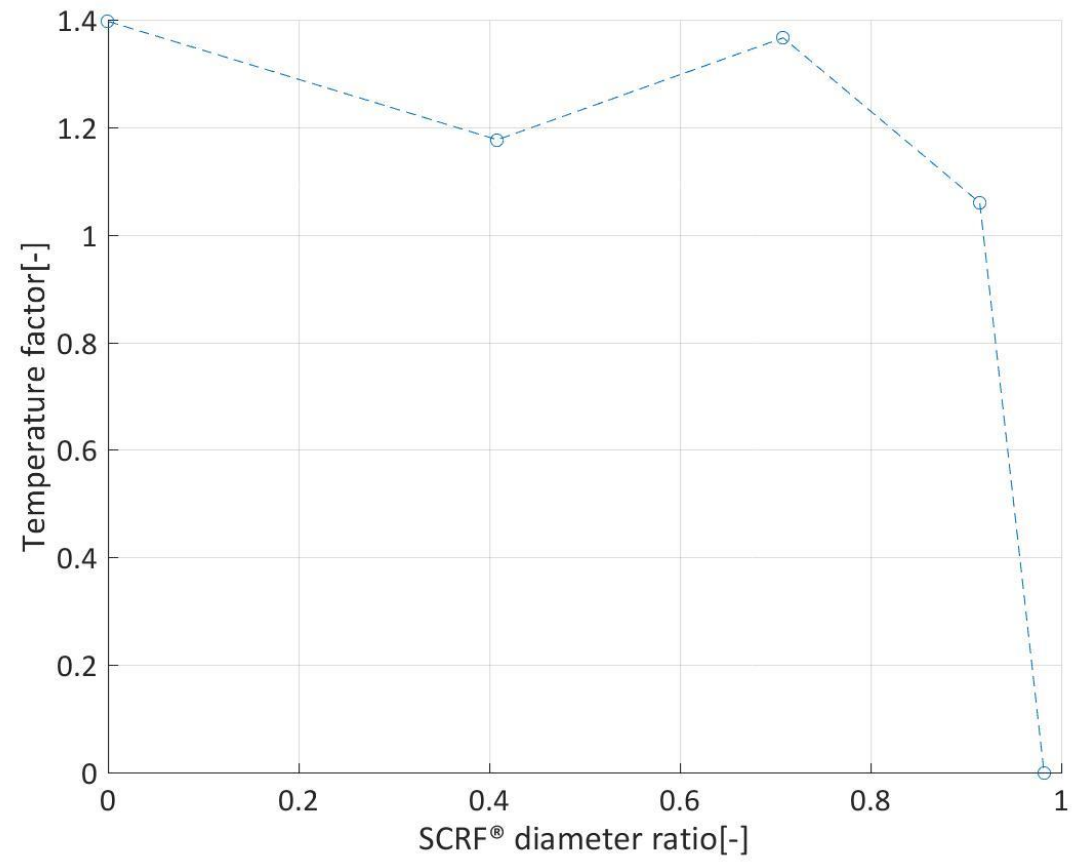

Figure F.6 Temperature boundary layer at $\mathrm{SCRF}^{\circledR}$ inlet at 5.8 hrs. for test point 8 during Stage 2 loading of $2 \mathrm{~g} / \mathrm{L}$ 


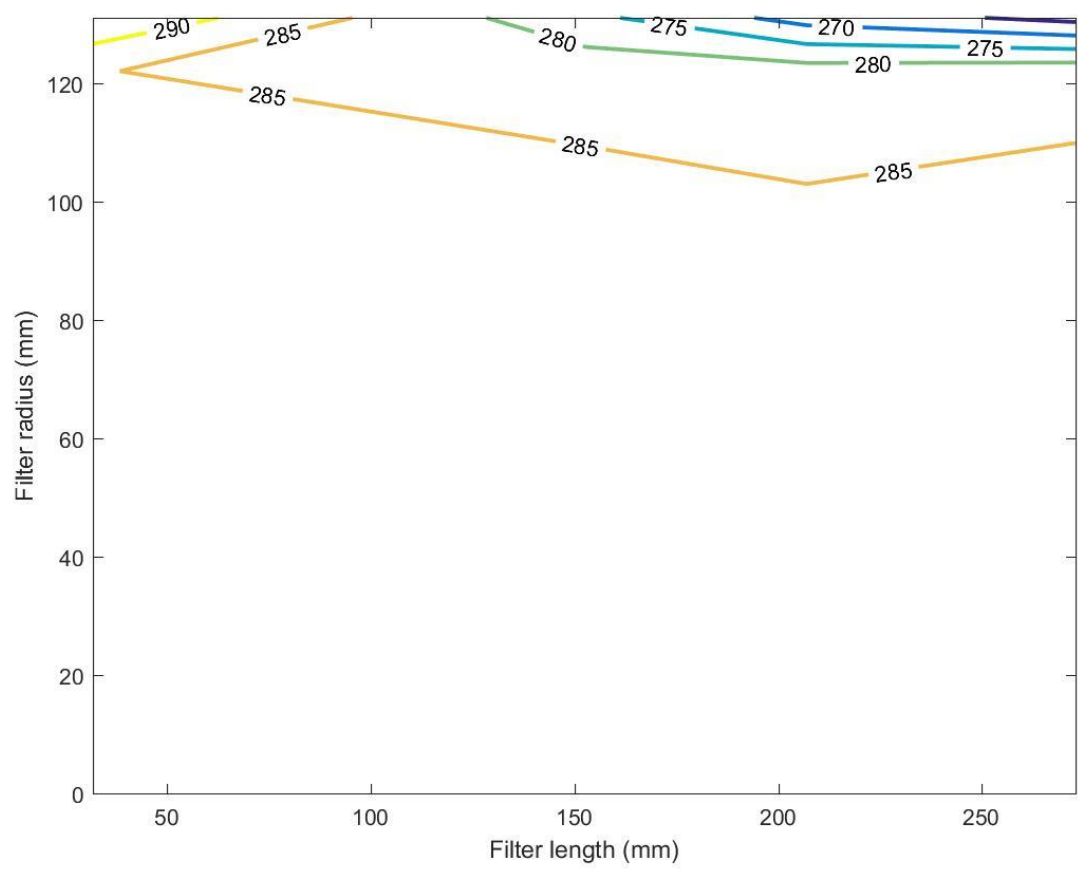

Figure F.7 Temperature distribution in the $\mathrm{SCRF}^{\circledR}$ for test point 1 at $1.7 \mathrm{hrs}$. during Stage 2 loading of $2 \mathrm{~g} / \mathrm{L}$

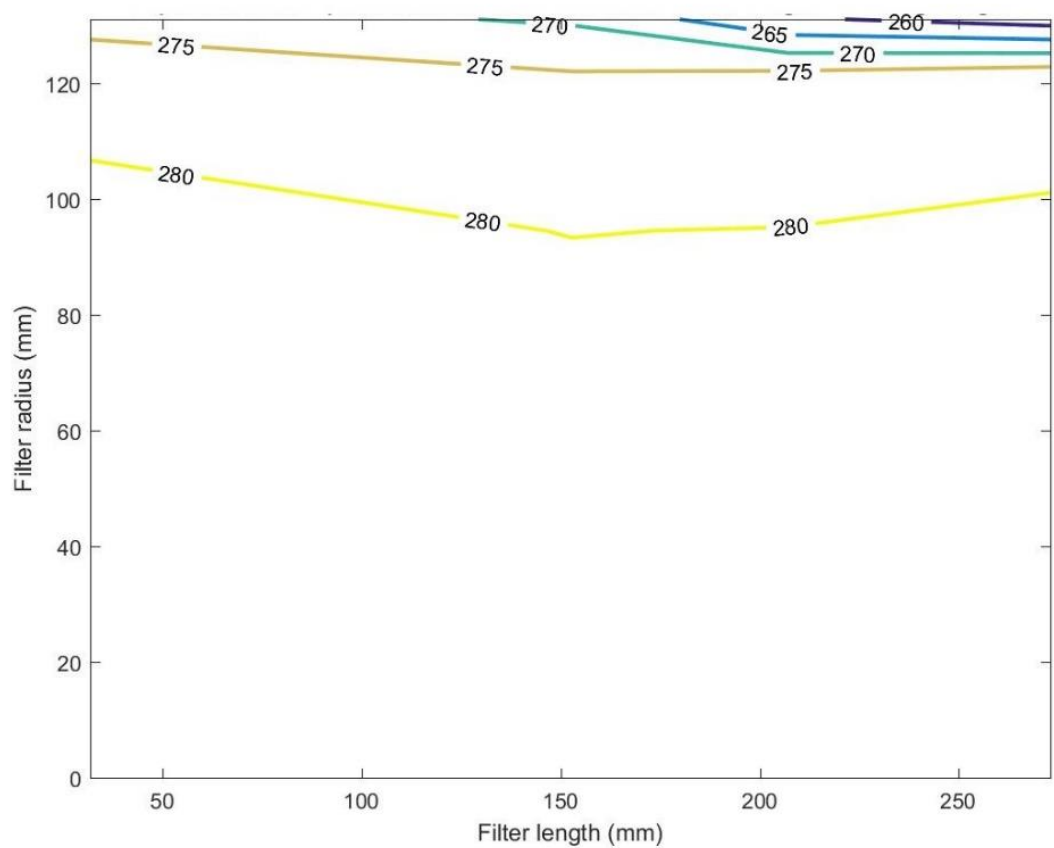

Figure F.8 Temperature distribution in the $\mathrm{SCRF}^{\circledR}$ for test point 3 at $3.3 \mathrm{hrs}$. during Stage 2 loading at $2 \mathrm{~g} / \mathrm{L}$ 


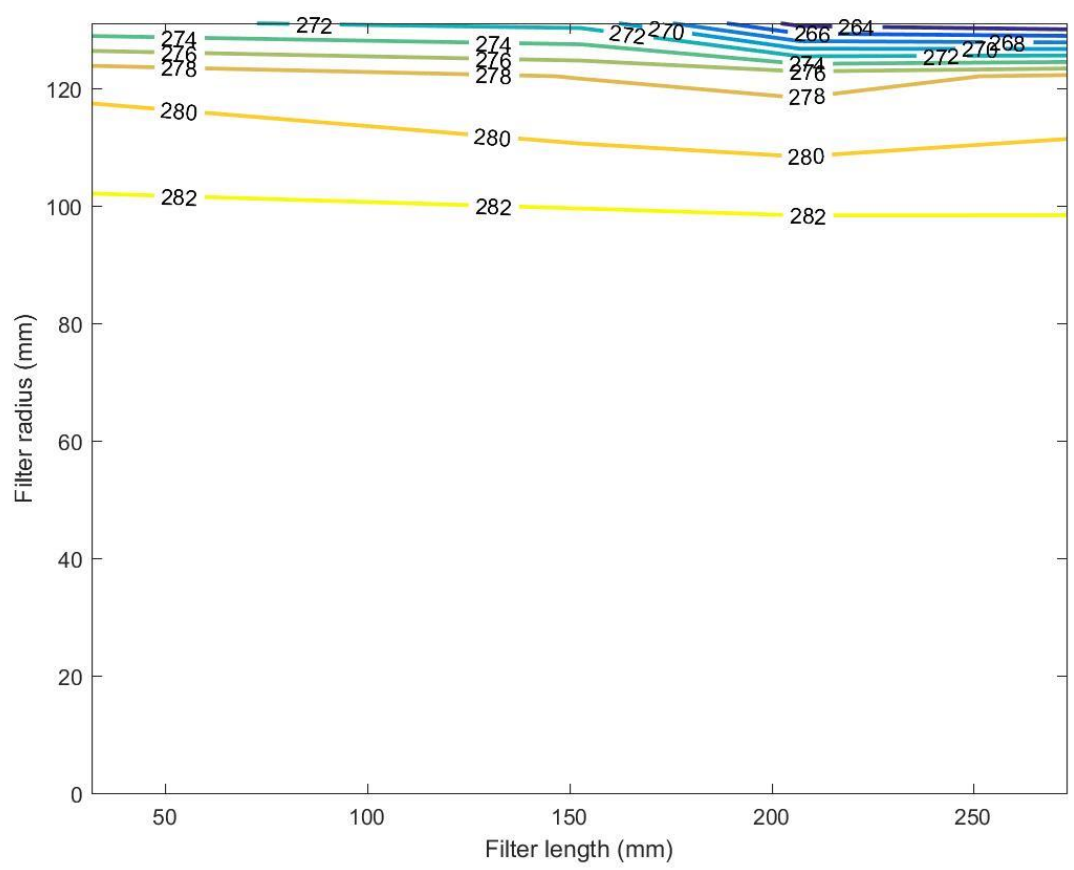

Figure F.9 Temperature distribution in the $\mathrm{SCRF}^{\circledR}$ for test point 6 at 4.2 hrs. during Stage 2 loading at $2 \mathrm{~g} / \mathrm{L}$

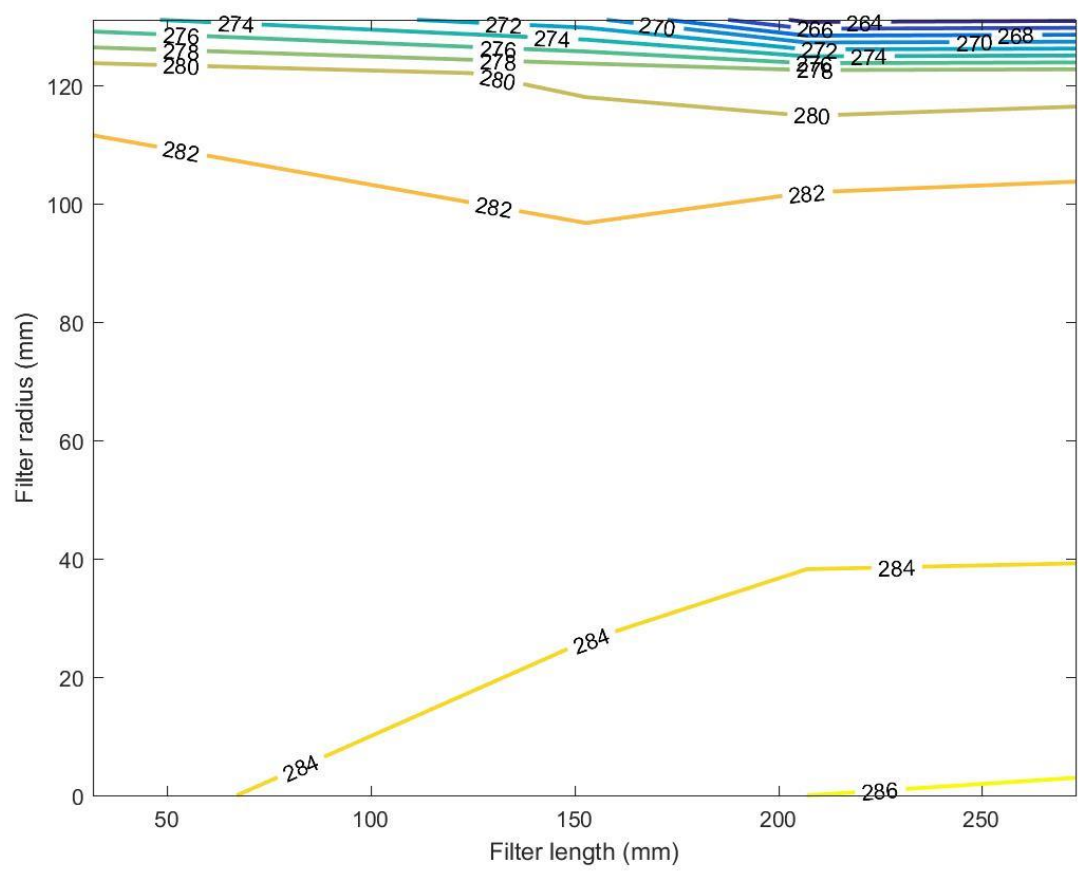

Figure F.10 Temperature distribution in the $\mathrm{SCRF}^{\circledast}$ for test point 8 at 5.8 hrs. during Stage 2 loading at $2 \mathrm{~g} / \mathrm{L}$ 


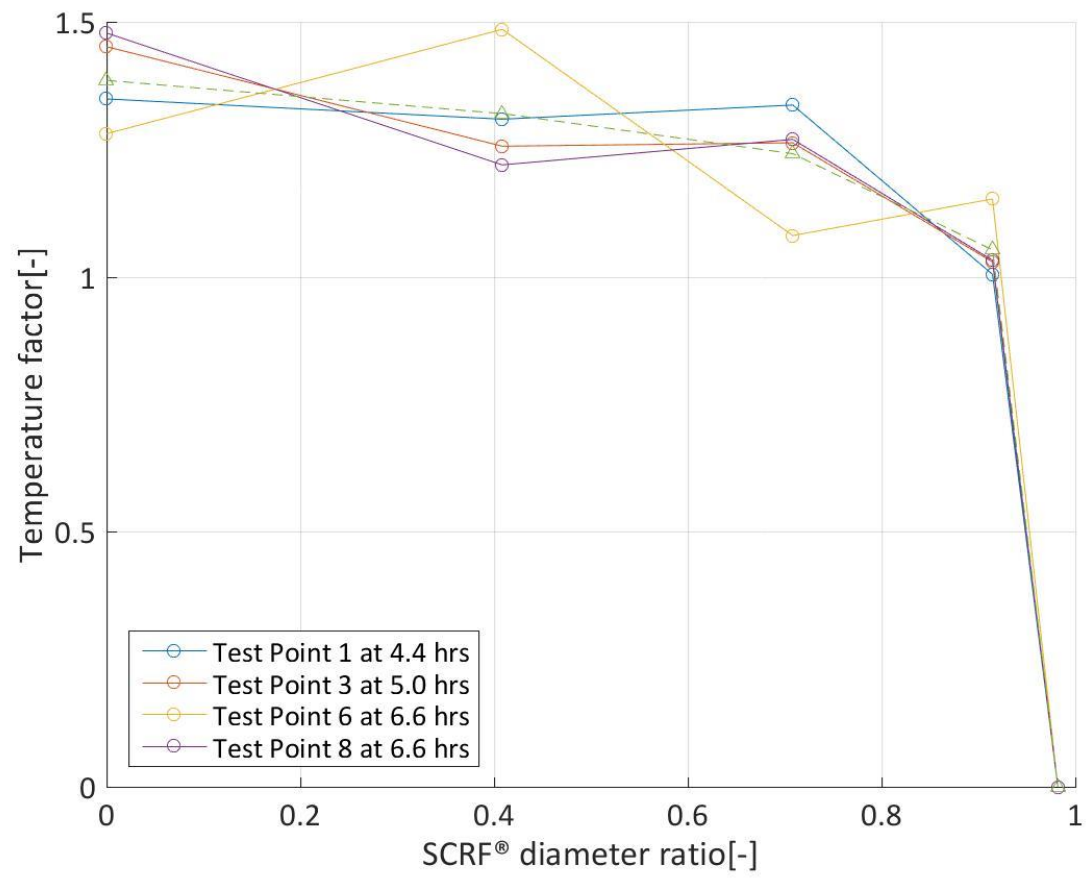

Figure F.11 Temperature boundary layer at $\mathrm{SCRF}^{\circledR}$ inlet for Stage 2 loading at $4 \mathrm{~g} / \mathrm{L}$

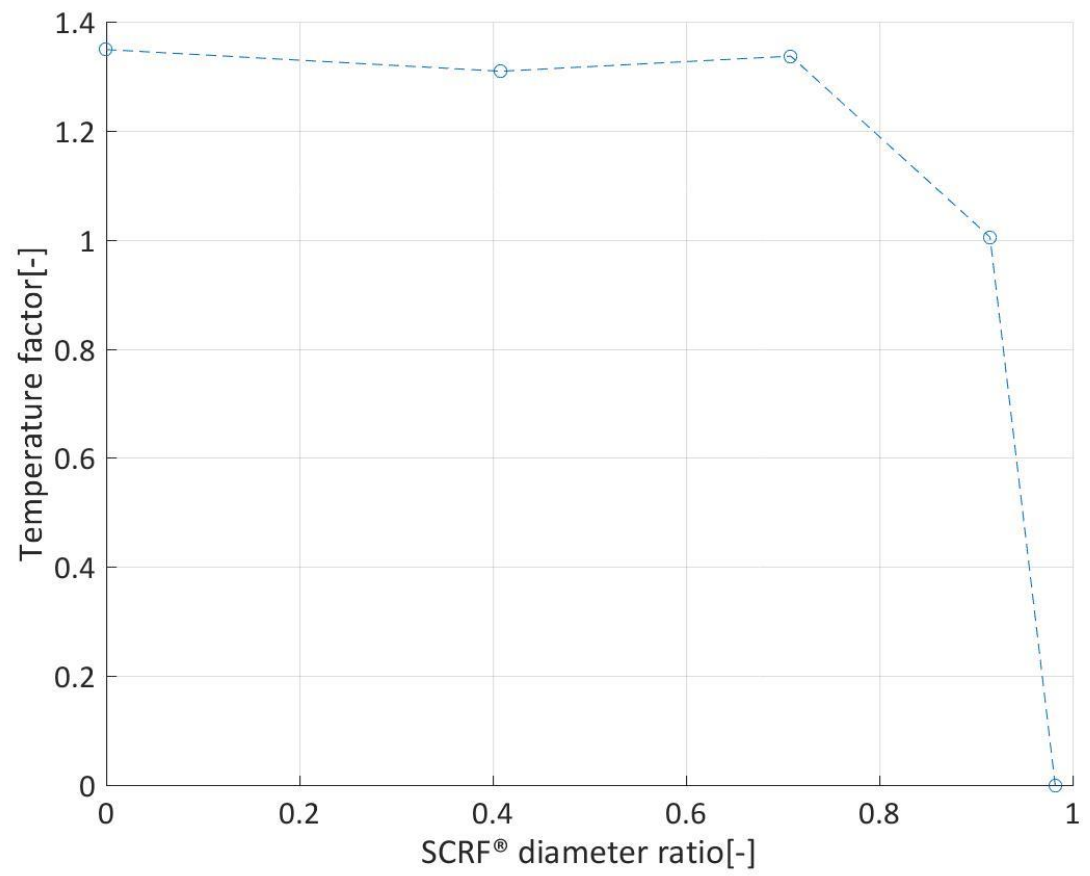

Figure F.12 Temperature distribution at $\mathrm{SCRF}^{\circledR}$ inlet for test point 1 at $4.4 \mathrm{hrs}$. during Stage 2 loading at $4 \mathrm{~g} / \mathrm{L}$ 


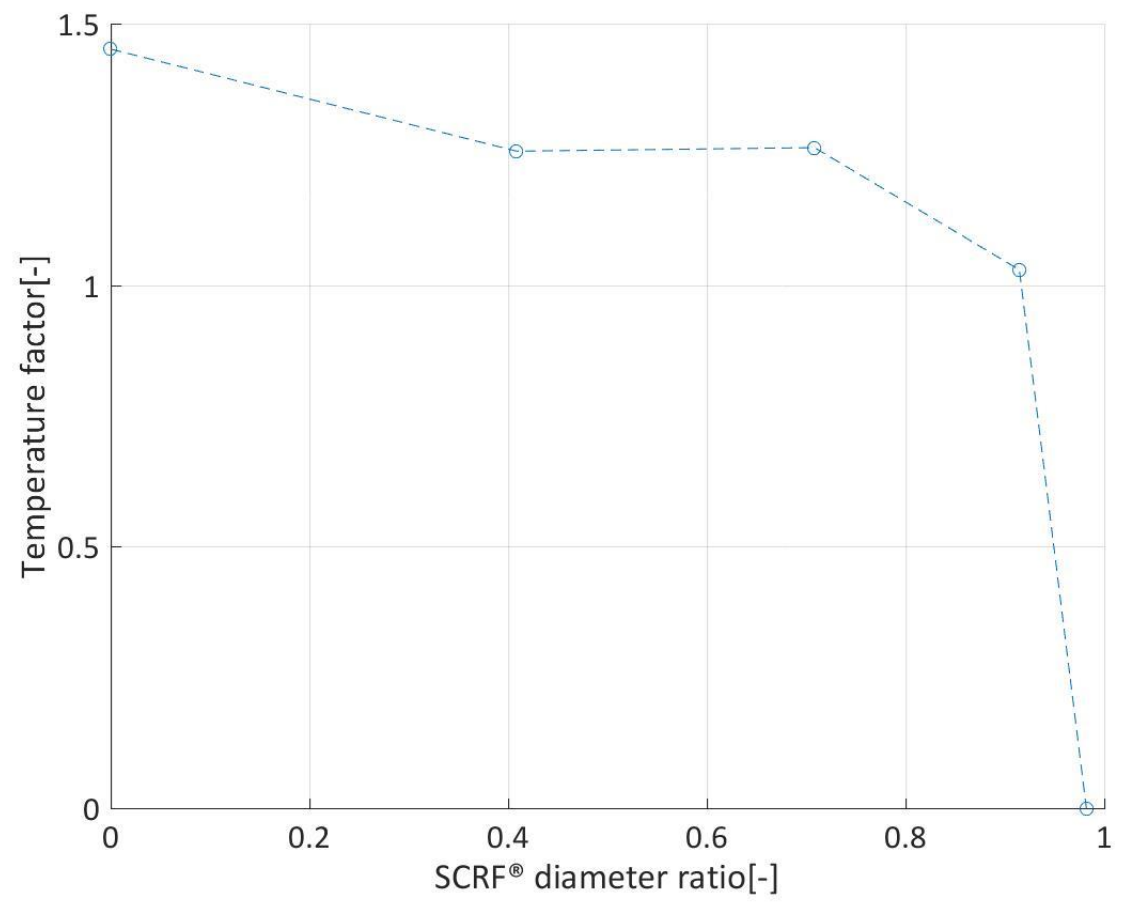

Figure F.13 Temperature distribution at $\mathrm{SCRF}^{\circledR}$ inlet for test point 3 at $5.0 \mathrm{hrs}$. during Stage 2 loading at $4 \mathrm{~g} / \mathrm{L}$

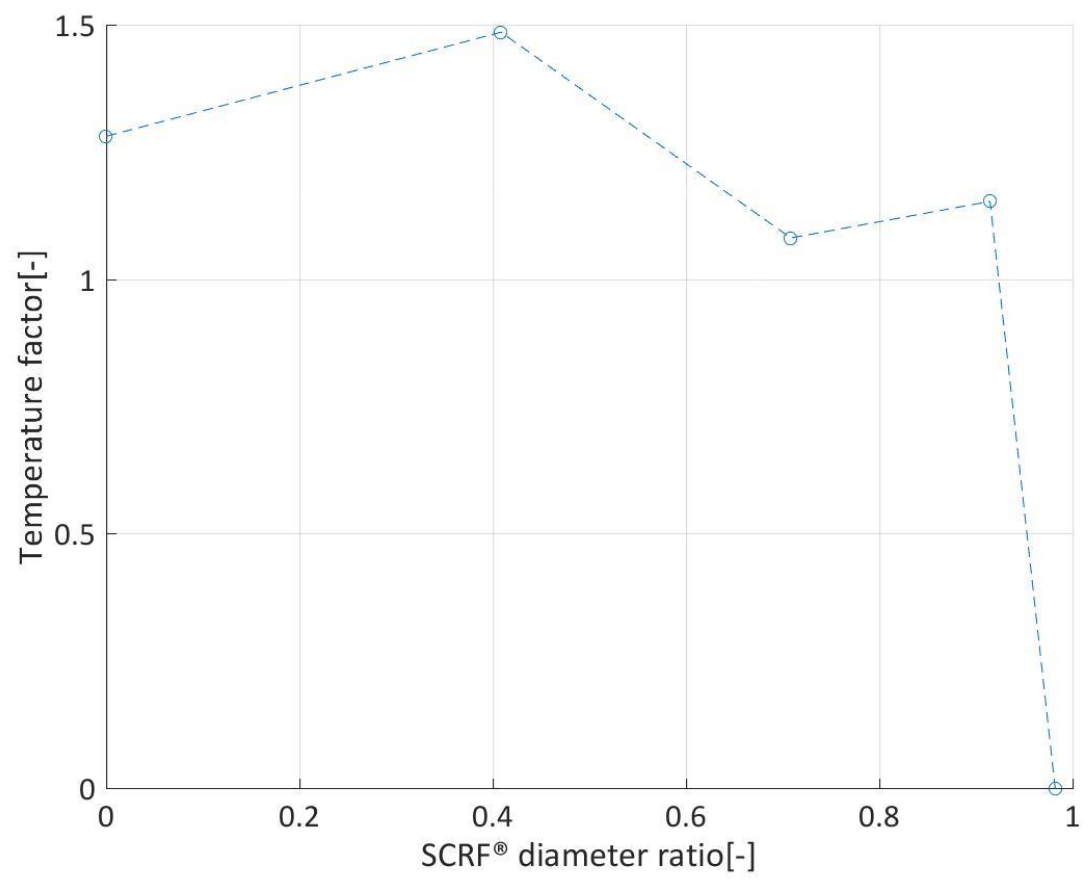

Figure F.14 Temperature distribution at $\mathrm{SCRF}^{\circledR}$ inlet for test point 6 at $6.6 \mathrm{hrs}$. during Stage 2 loading at $4 \mathrm{~g} / \mathrm{L}$ 


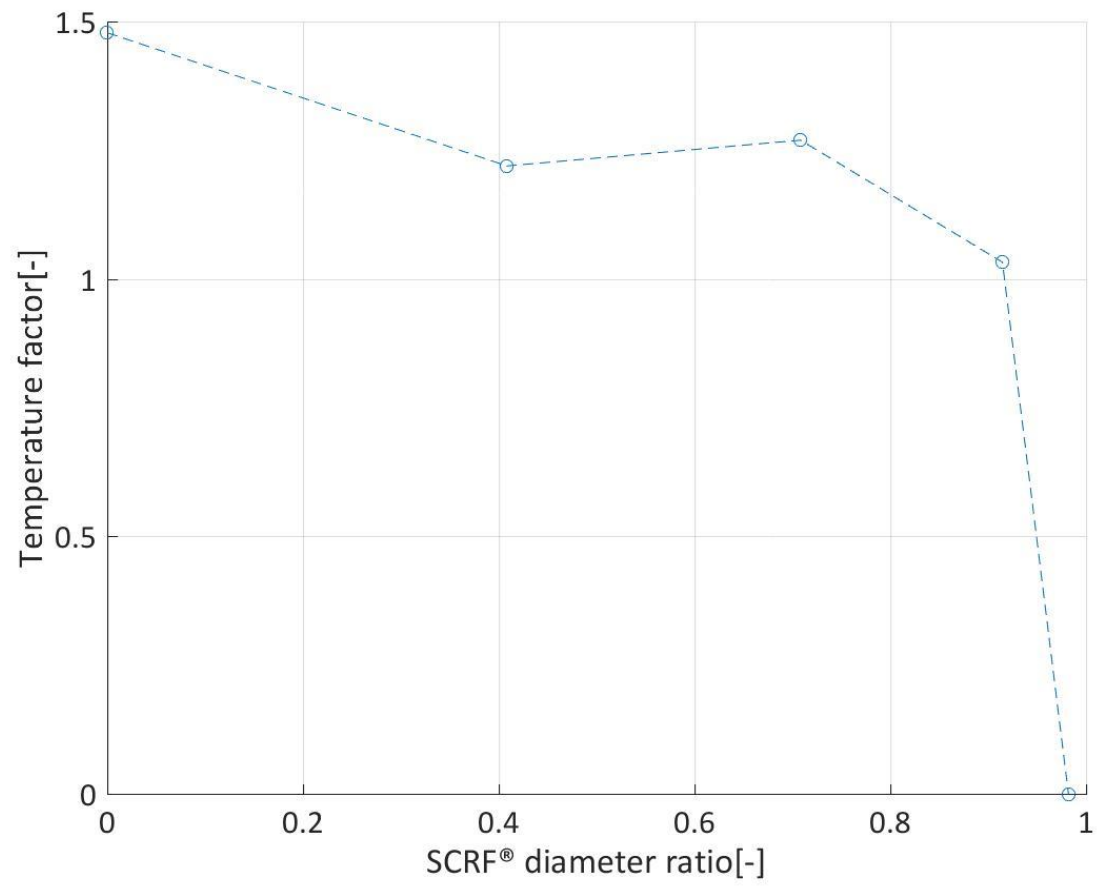

Figure F.15 Temperature distribution at $\mathrm{SCRF}^{\circledR}$ inlet for test point 8 at $6.6 \mathrm{hrs}$. during Stage 2 loading at $4 \mathrm{~g} / \mathrm{L}$

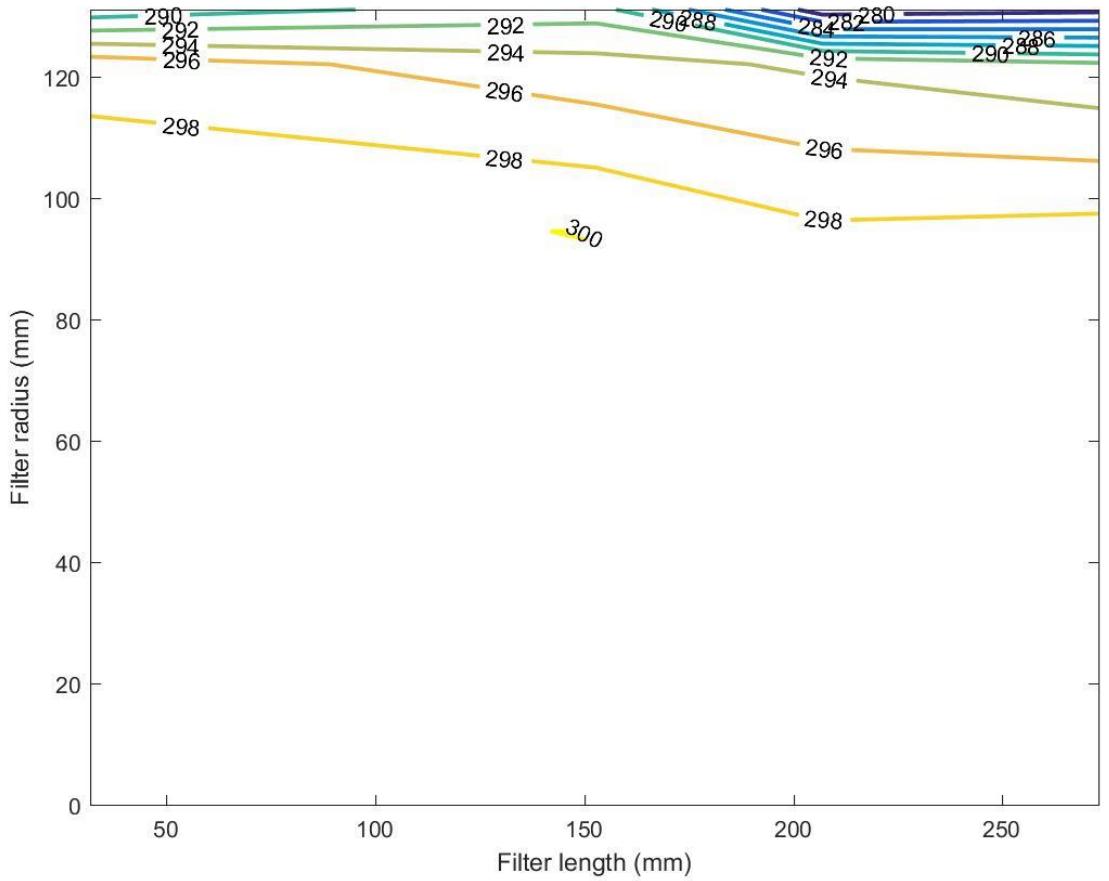

Figure F.16 Temperature distribution in the $\mathrm{SCRF}^{\circledR}$ for test point 1 at $4.4 \mathrm{hrs}$. during Stage 2 loading at $4 \mathrm{~g} / \mathrm{L}$ 


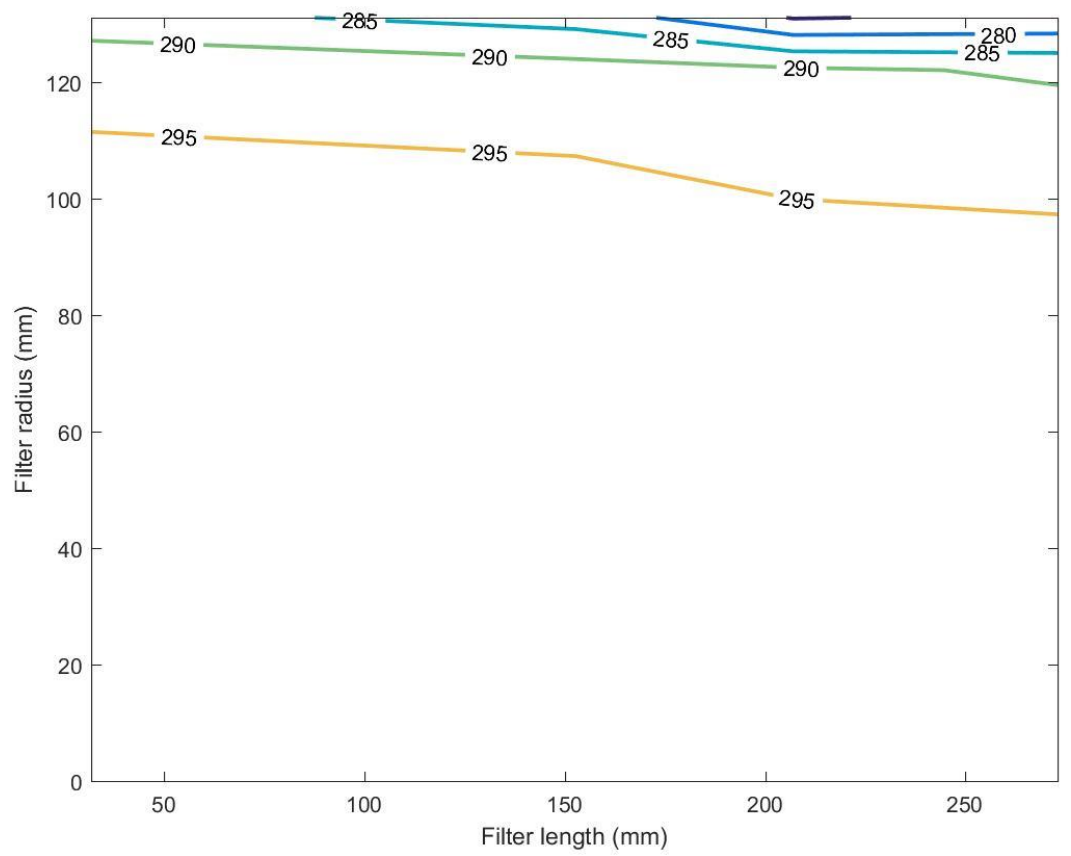

Figure F.17 Temperature distribution in the $\mathrm{SCRF}^{\circledR}$ for test point 3 at 5.0 hrs. during Stage 2 loading at $4 \mathrm{~g} / \mathrm{L}$

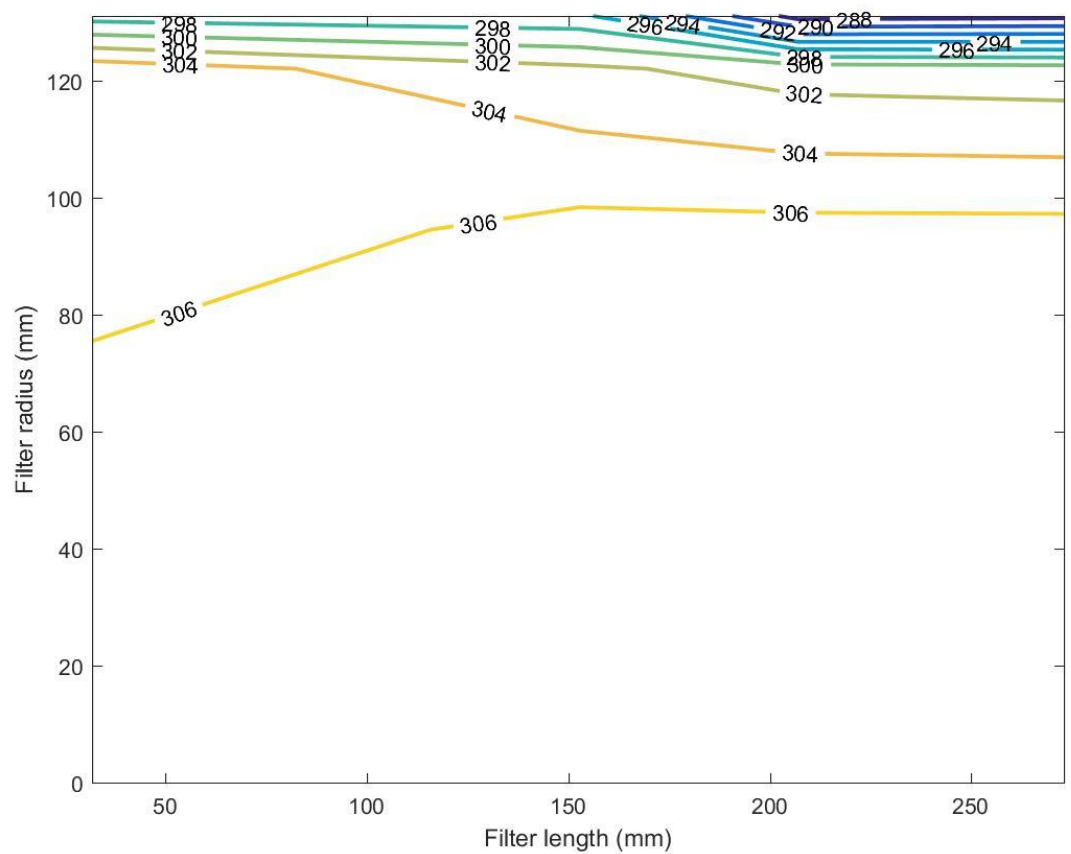

Figure F.18 Temperature distribution in the $\mathrm{SCRF}^{\circledast}$ for test point 6 at $6.6 \mathrm{hrs}$. during Stage 2 loading at $4 \mathrm{~g} / \mathrm{L}$ 


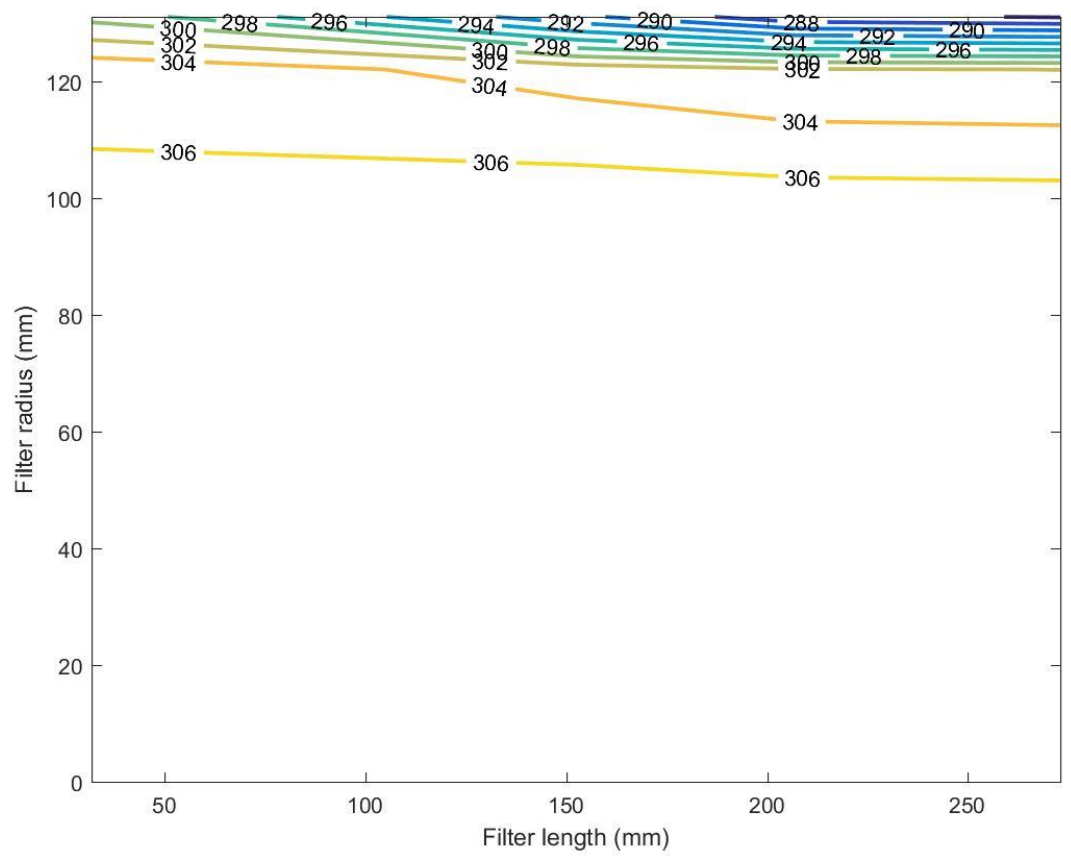

Figure F.19 Temperature distribution in the $\mathrm{SCRF}^{\circledR}$ for test point 8 at 6.6 hrs. during Stage 2 loading at $4 \mathrm{~g} / \mathrm{L}$

\section{$\mathrm{NO}_{\mathrm{x}}$ Reduction Stage}

Figures in this section show the temperature distribution in the axial and radial position of the $\mathrm{SCRF}^{\circledR}$ for different NOx Reduction test points when dosed with ANR - 1 . The temperature reading were considered for the time at the end of ANR - 1 dosing cycle to get stabilized temperature values. The plots of temperature boundary at the inlet of the $\mathrm{SCRF}^{\circledR}$ show the radially decreasing temperature for all tests of $\mathrm{NO}_{\mathrm{x}}$ reduction stage. The temperature profiles depict axially increasing temperatures across the $\mathrm{SCRF}^{\circledR}$ as can be seen in figures for different loading condition. This can be attributed to the $\mathrm{PM}$ oxidation in $\mathrm{PM}$ loaded $\mathrm{SCRF}^{\circledR}$ at respective temperatures. It is shown in Figures F.27, F.36, and F.45, that for test point 6 with 0, 2, and $4 \mathrm{~g} / \mathrm{L} \mathrm{PM}$ loading in the $\mathrm{SCRF}^{\circledR}$ with urea dosing, the axial temperatures gradient across the $\mathrm{SCRF}^{\circledR}$ is high as compared to other test points. The time at which temperature boundary at inlet $\mathrm{SCRF}^{\circledR}$ and temperature distribution in the $\mathrm{SCRF}^{\circledR}$ is plotted is given in Figures F.3, F.4, and F.5. 


\section{Loading at $0 \mathrm{~g} / \mathrm{L}$}

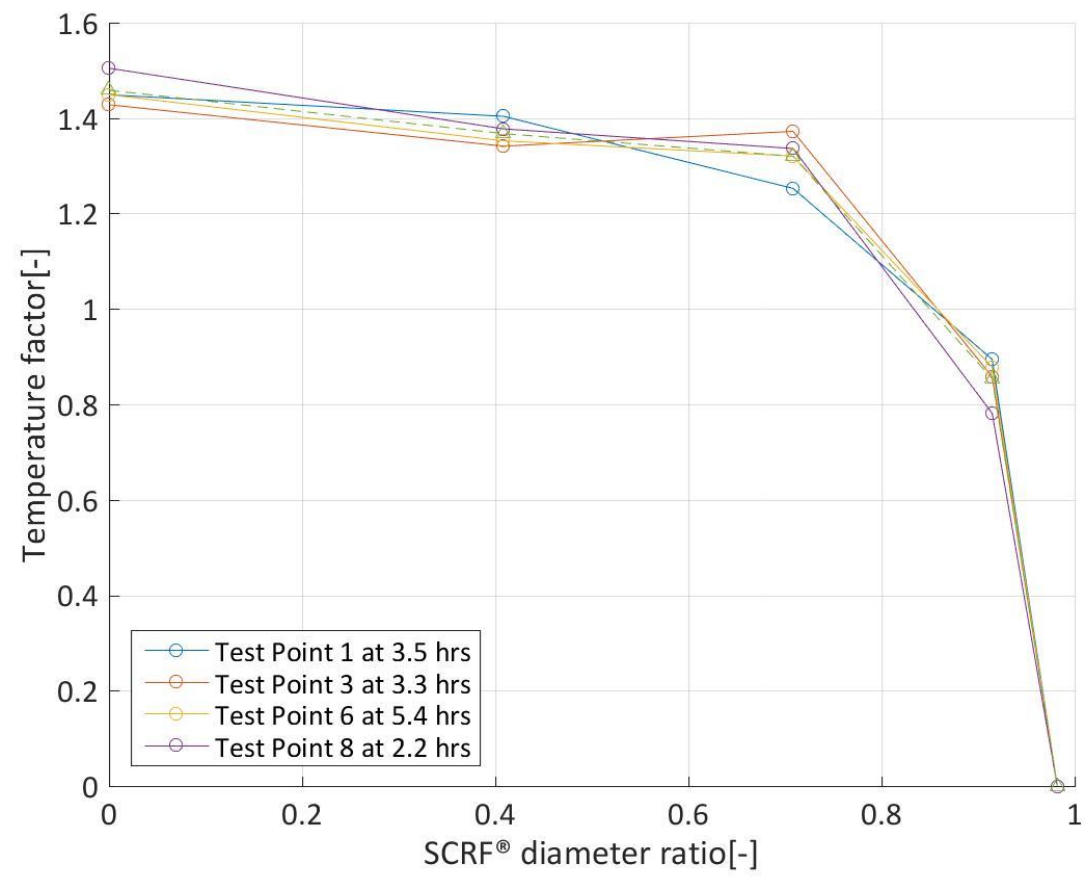

Figure F.20 Temperature boundary layer at $\mathrm{SCRF}^{\circledR}$ inlet for $\mathrm{NO}_{\mathrm{x}}$ Reduction Stage (loading at $0 \mathrm{~g} / \mathrm{L}$ )

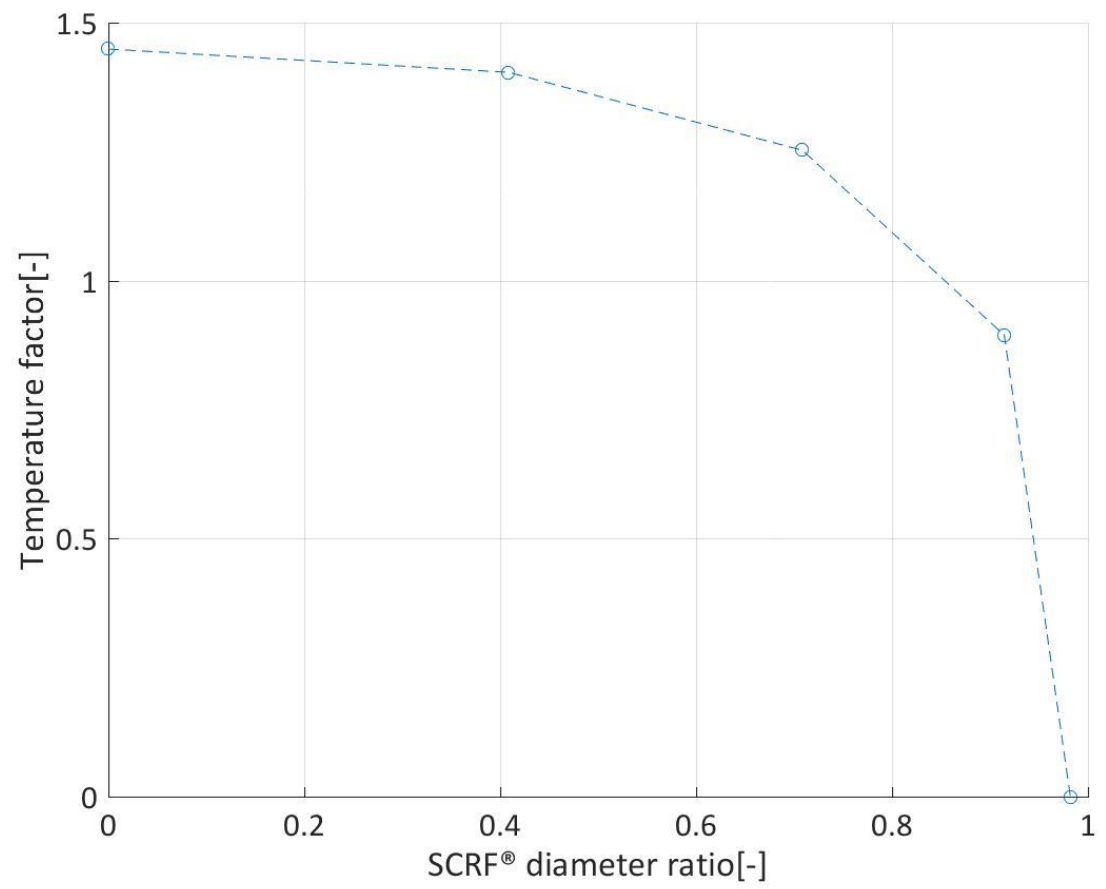

Figure F.21 Temperature distribution at $\mathrm{SCRF}^{\circledR}$ inlet for test point 1 at $3.5 \mathrm{hrs}$. during $\mathrm{NO}_{\mathrm{x}}$ Reduction Stage (loading at $0 \mathrm{~g} / \mathrm{L}$ ) 


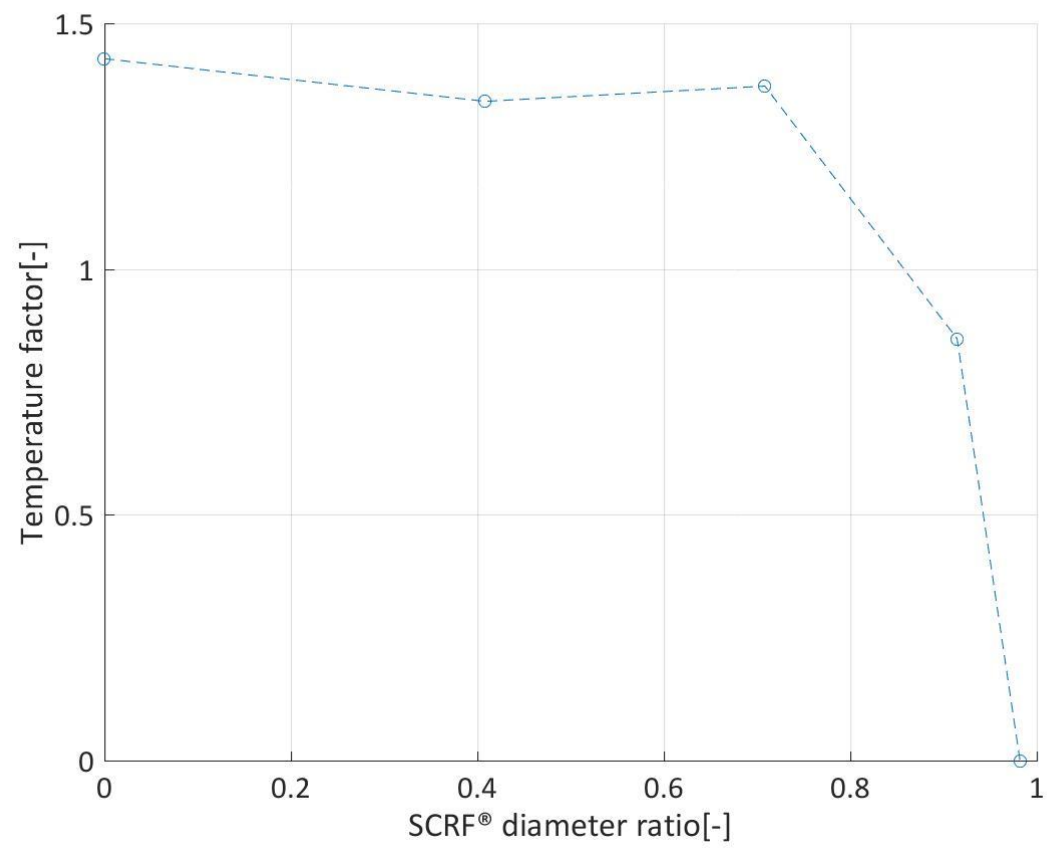

Figure F.22 Temperature distribution at $\mathrm{SCRF}^{\circledR}$ inlet for test point 3 at 3.3 hrs. during $\mathrm{NO}_{\mathrm{x}}$ Reduction Stage (loading at $0 \mathrm{~g} / \mathrm{L}$ )

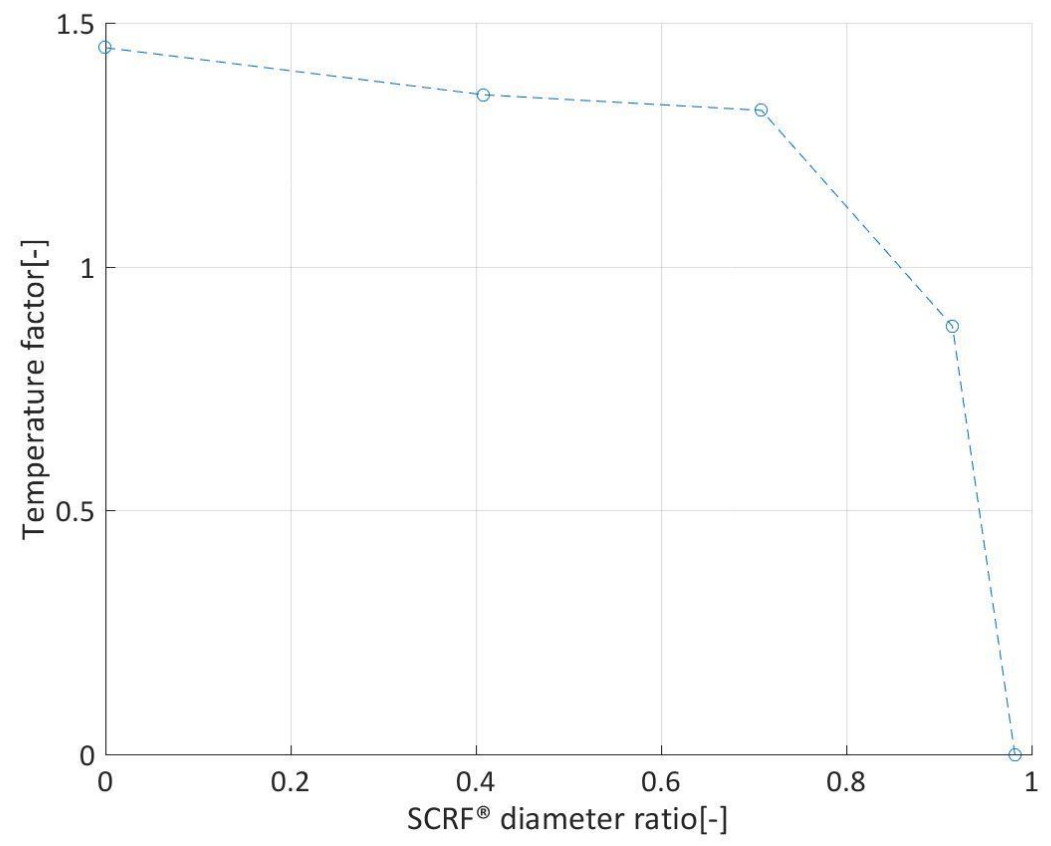

Figure F.23 Temperature distribution at $\mathrm{SCRF}^{\circledR}$ inlet for test point 6 at 5.4 hrs. during $\mathrm{NO}_{\mathrm{x}}$ Reduction Stage (loading at $0 \mathrm{~g} / \mathrm{L}$ ) 


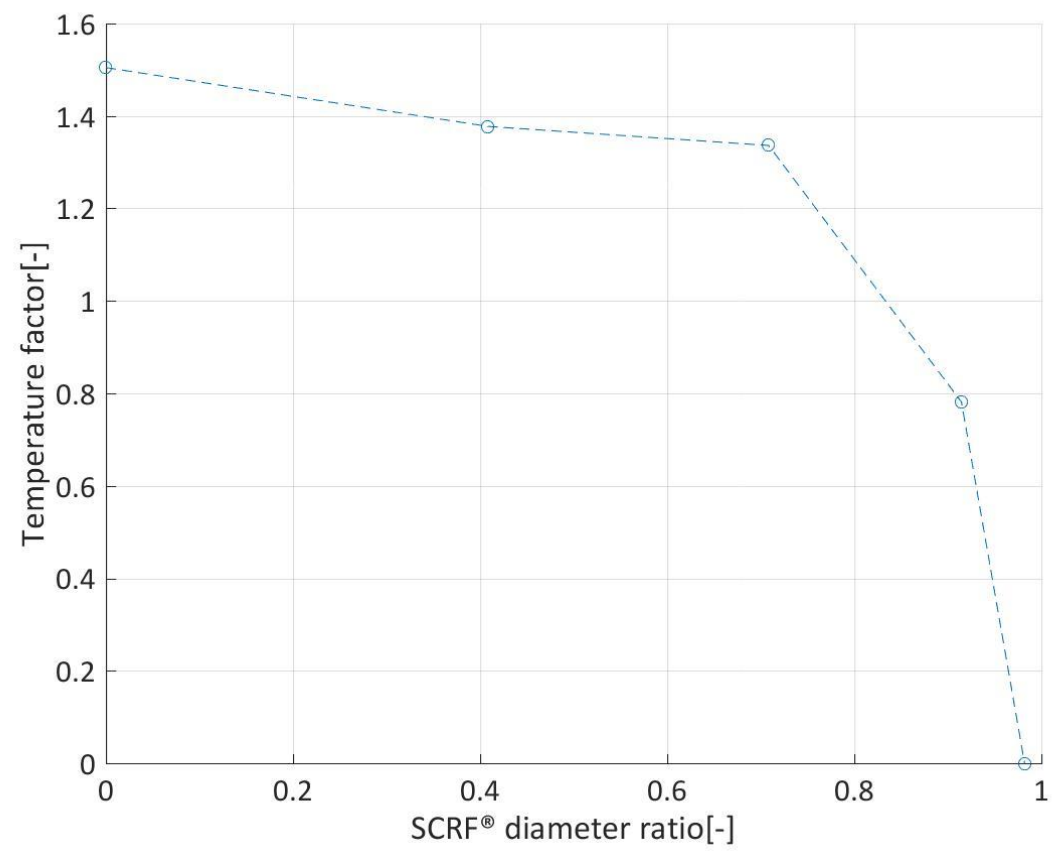

Figure F.24 Temperature distribution at $\mathrm{SCRF}^{\circledR}$ inlet for test point 8 at $2.2 \mathrm{hrs}$. during $\mathrm{NO}_{\mathrm{x}}$ Reduction Stage (loading at $0 \mathrm{~g} / \mathrm{L}$ )

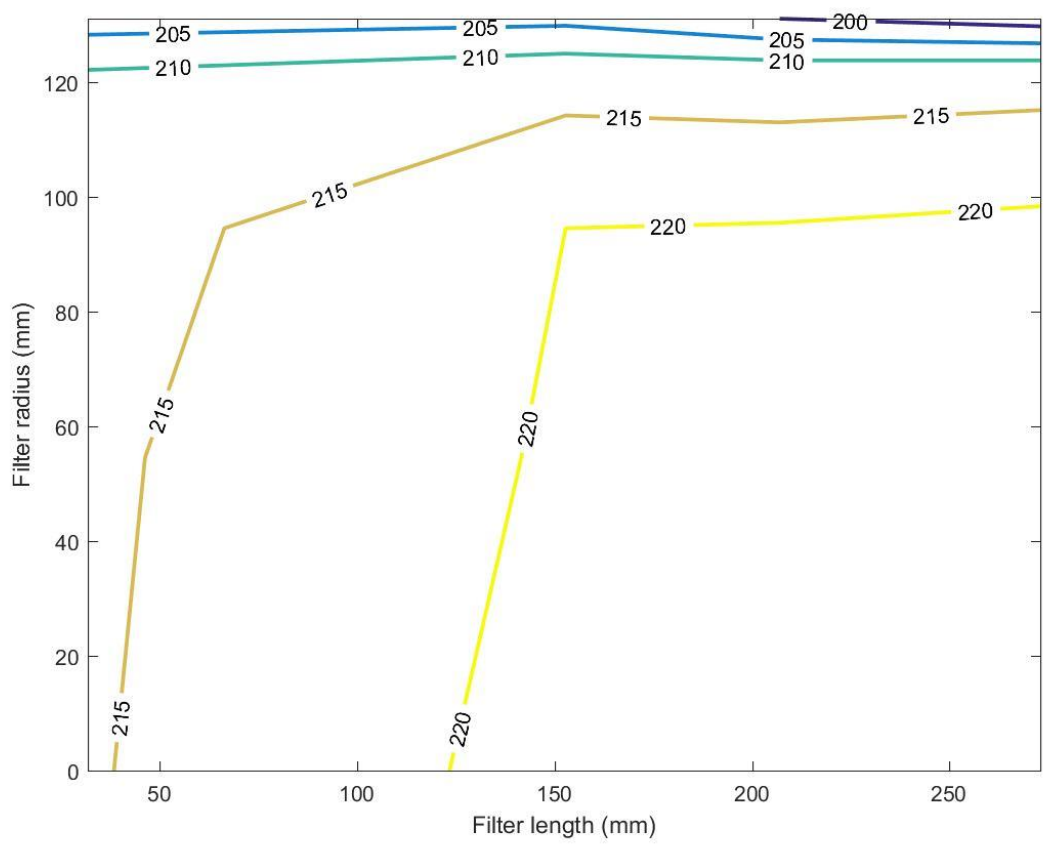

Figure F.25 Temperature distribution in the $\mathrm{SCRF}^{\circledR}$ for test point 1 at 3.5 hrs. during $\mathrm{NO}_{\mathrm{x}}$ Reduction Stage (loading at $0 \mathrm{~g} / \mathrm{L}$ ) 


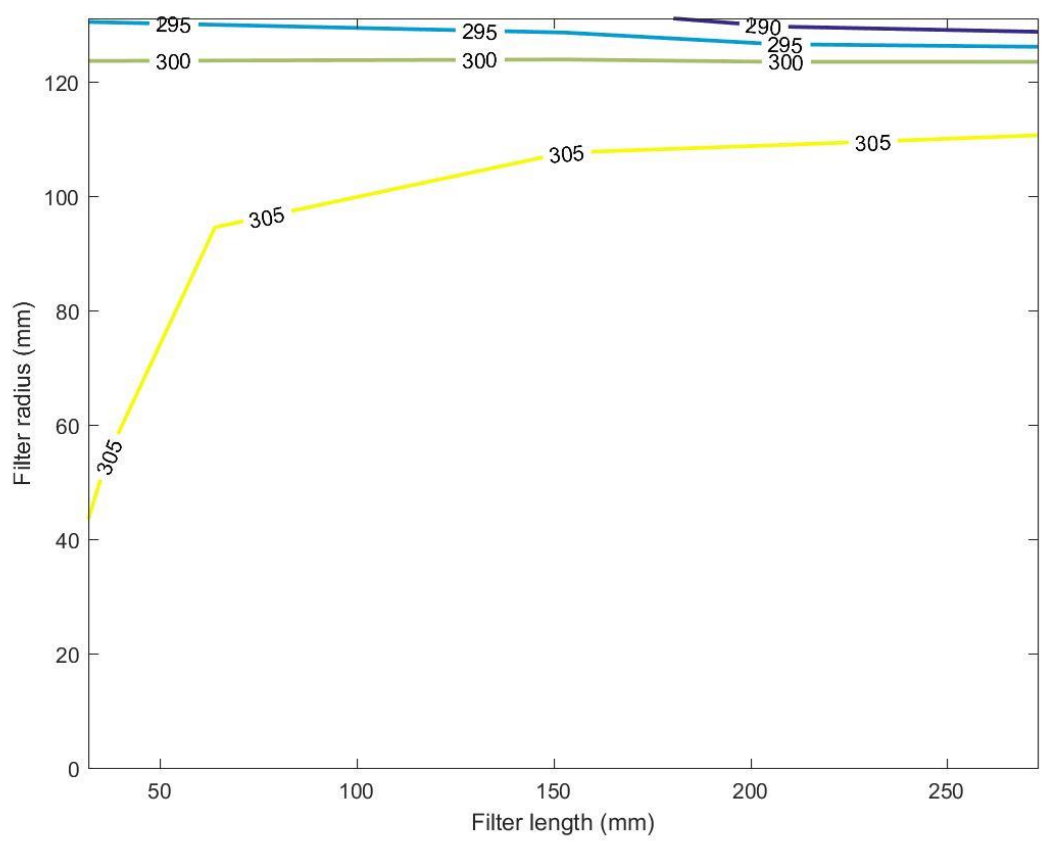

Figure F.26 Temperature distribution in the $\mathrm{SCRF}^{\circledR}$ for test point 3 at $3.3 \mathrm{hrs}$. during $\mathrm{NO}_{\mathrm{x}}$ Reduction Stage (loading at $0 \mathrm{~g} / \mathrm{L}$ )

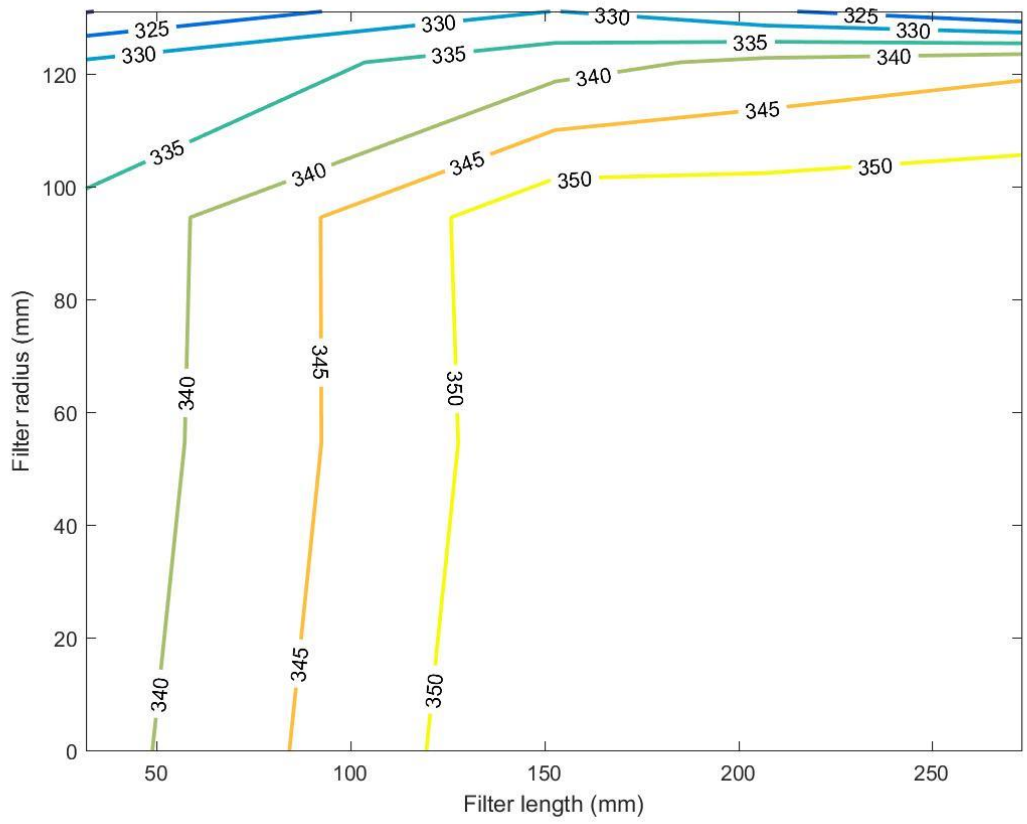

Figure F.27 Temperature distribution in the $\mathrm{SCRF}^{\circledR}$ for test point 6 at 5.4 hrs. during $\mathrm{NO}_{\mathrm{x}}$ Reduction Stage (loading at $0 \mathrm{~g} / \mathrm{L}$ ) 
Table F.3 Thermocouple temperatures at $\mathrm{NO}_{\mathrm{x}}$ reduction stage at $0 \mathrm{~g} / \mathrm{L}$

\begin{tabular}{|c|c|c|c|c|c|c|c|c|c|c|c|c|c|c|c|c|c|c|c|c|c|}
\hline \multirow{2}{*}{$\begin{array}{c}\text { NOx } \\
\text { Reduction } \\
\text { Stage - } 0 \\
\text { g/L }\end{array}$} & \multirow{2}{*}{$\begin{array}{l}\text { Time } \\
\text { [hr.] }\end{array}$} & \multicolumn{20}{|c|}{ SCRF $^{\circledR}$ Thermocouple Temperature $\left[{ }^{\circ} \mathrm{C}\right]$} \\
\hline & & S1 & S2 & S3 & $\mathrm{S} 4$ & S5 & S6 & S7 & S8 & S9 & S10 & $\mathrm{S} 11$ & $\mathrm{~S} 12$ & S13 & S14 & S15 & S16 & S17 & $\mathrm{S} 18$ & S19 & $\mathrm{S} 20$ \\
\hline 1 & 3.5 & 215 & 214 & $213^{1}$ & 210 & 203 & 222 & 221 & $220^{1}$ & $213^{1}$ & 204 & 222 & 221 & 220 & 212 & $200^{1}$ & 222 & 222 & 221 & 213 & 198 \\
\hline 3 & 3.3 & 306 & 305 & 305 & 301 & 295 & 310 & 308 & 308 & $302^{1}$ & 292 & 309 & 308 & 308 & $302^{1}$ & 288 & 308 & $308^{1}$ & $308^{1}$ & 303 & 286 \\
\hline 6 & 5.4 & 338 & 336 & $336^{1}$ & 331 & 320 & 355 & 354 & $354^{1}$ & $338^{1}$ & 330 & 355 & 354 & 353 & 341 & $326^{1}$ & 355 & 355 & 354 & 344 & 320 \\
\hline 8 & 2.2 & 444 & 442 & $442^{1}$ & 437 & 430 & 451 & 448 & $448^{1}$ & $439^{1}$ & 430 & 450 & 449 & 449 & 440 & $426^{1}$ & 449 & 449 & 449 & 443 & 422 \\
\hline
\end{tabular}

1The highlighted thermocouple temperature have been approximated on the basis of the trend of thermocouple temperatures in other test points. 


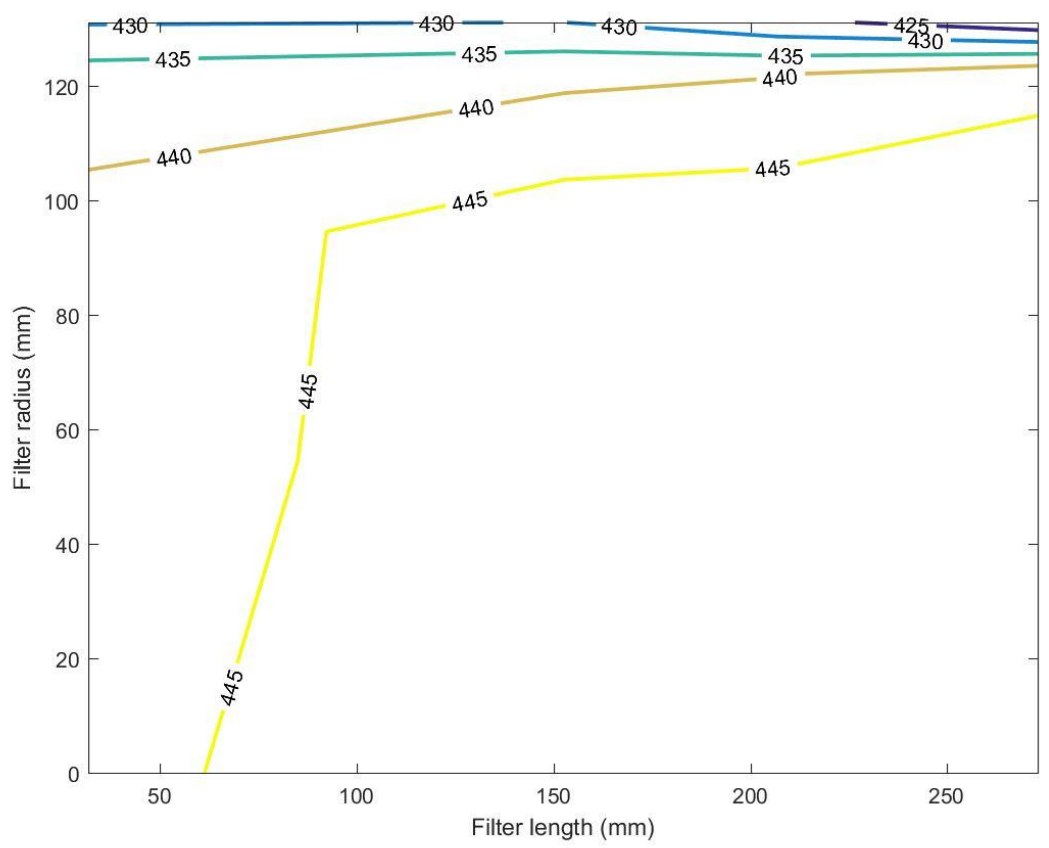

Figure F.28 Temperature distribution in the $\mathrm{SCRF}^{\circledR}$ for test point 8 at $2.2 \mathrm{hrs}$. during $\mathrm{NO}_{\mathrm{x}}$ Reduction Stage (loading at $0 \mathrm{~g} / \mathrm{L}$ ) 


\section{Loading at $2 \mathrm{~g} / \mathrm{L}$}

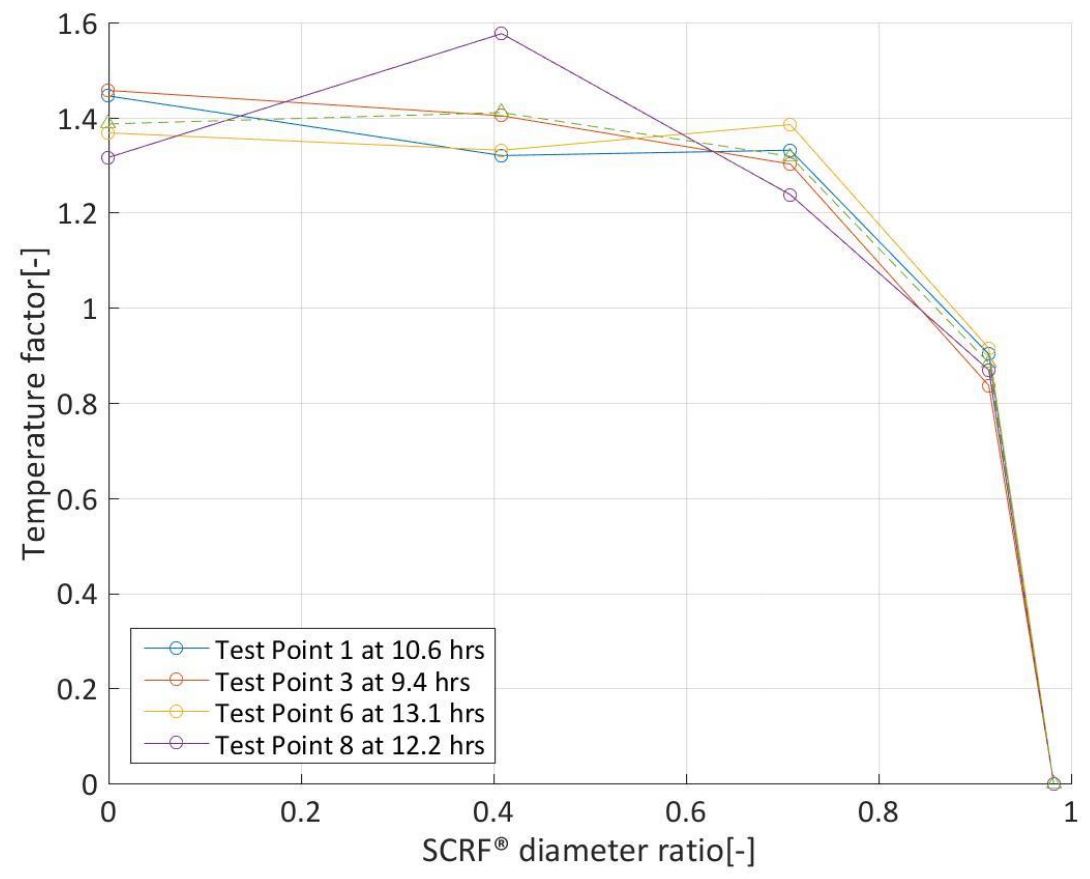

Figure F.29 Temperature boundary layer at $\mathrm{SCRF}^{\circledR}$ inlet for $\mathrm{NO}_{\mathrm{x}}$ Reduction Stage (loading at $2 \mathrm{~g} / \mathrm{L}$ )

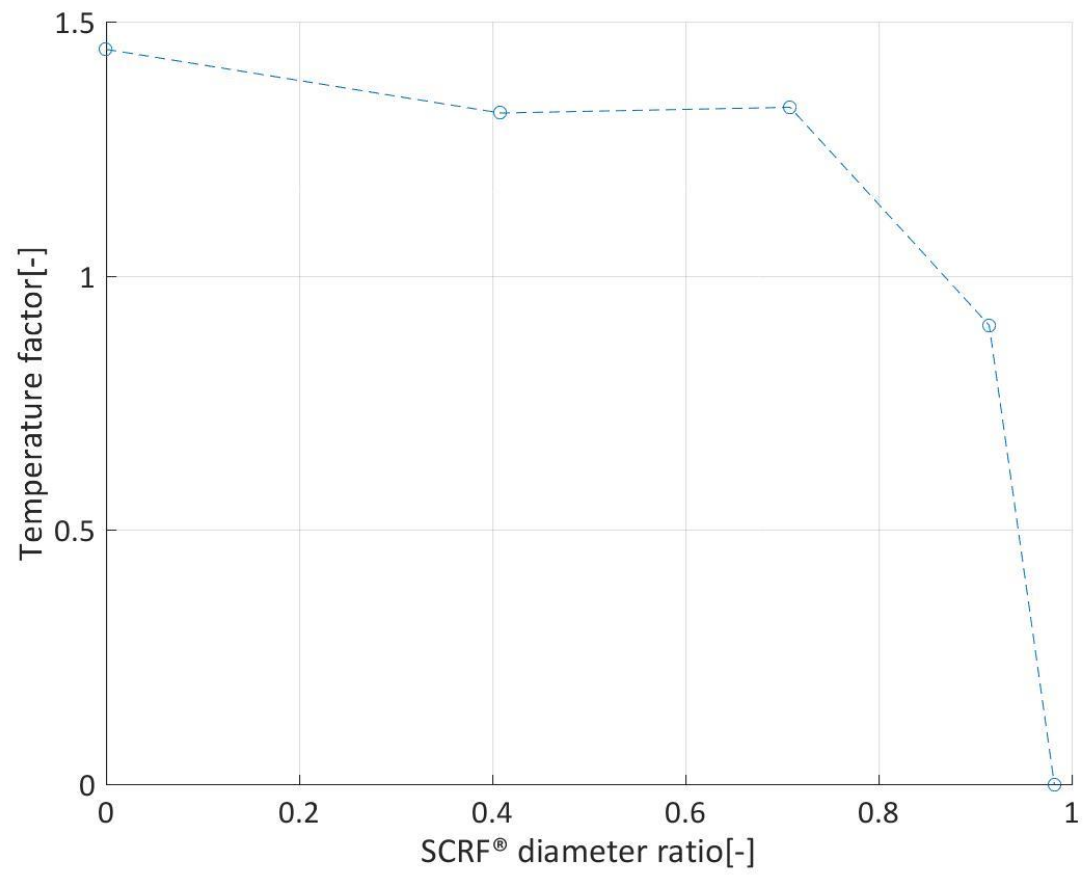

Figure F.30 Temperature distribution at $\mathrm{SCRF}^{\circledast}$ inlet for test point 1 at $10.6 \mathrm{hrs}$. during $\mathrm{NO}_{\mathrm{x}}$ Reduction Stage (loading at $2 \mathrm{~g} / \mathrm{L}$ ) 


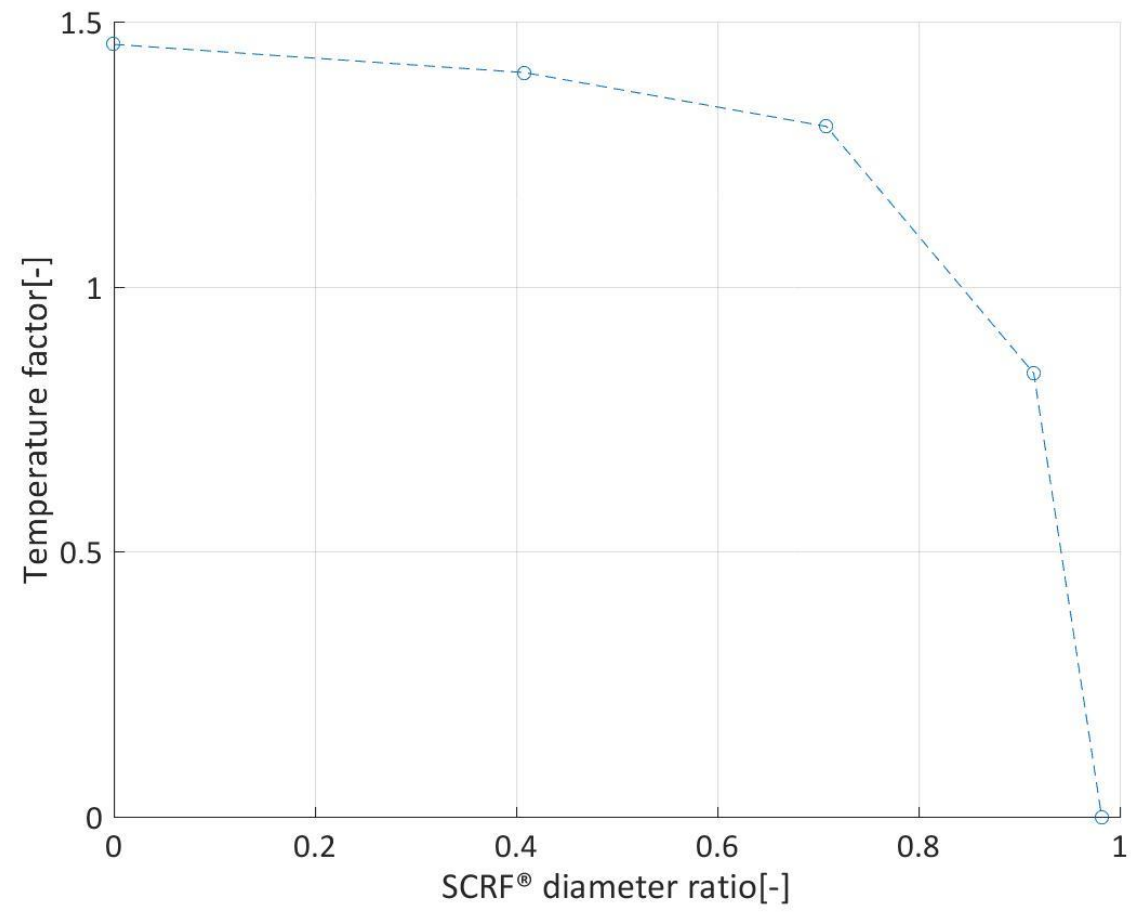

Figure F.31Temperature distribution at $\mathrm{SCRF}^{\circledR}$ inlet for test point 3 at 9.4 hrs. during $\mathrm{NO}_{\mathrm{x}}$ Reduction Stage (loading at $2 \mathrm{~g} / \mathrm{L}$ )

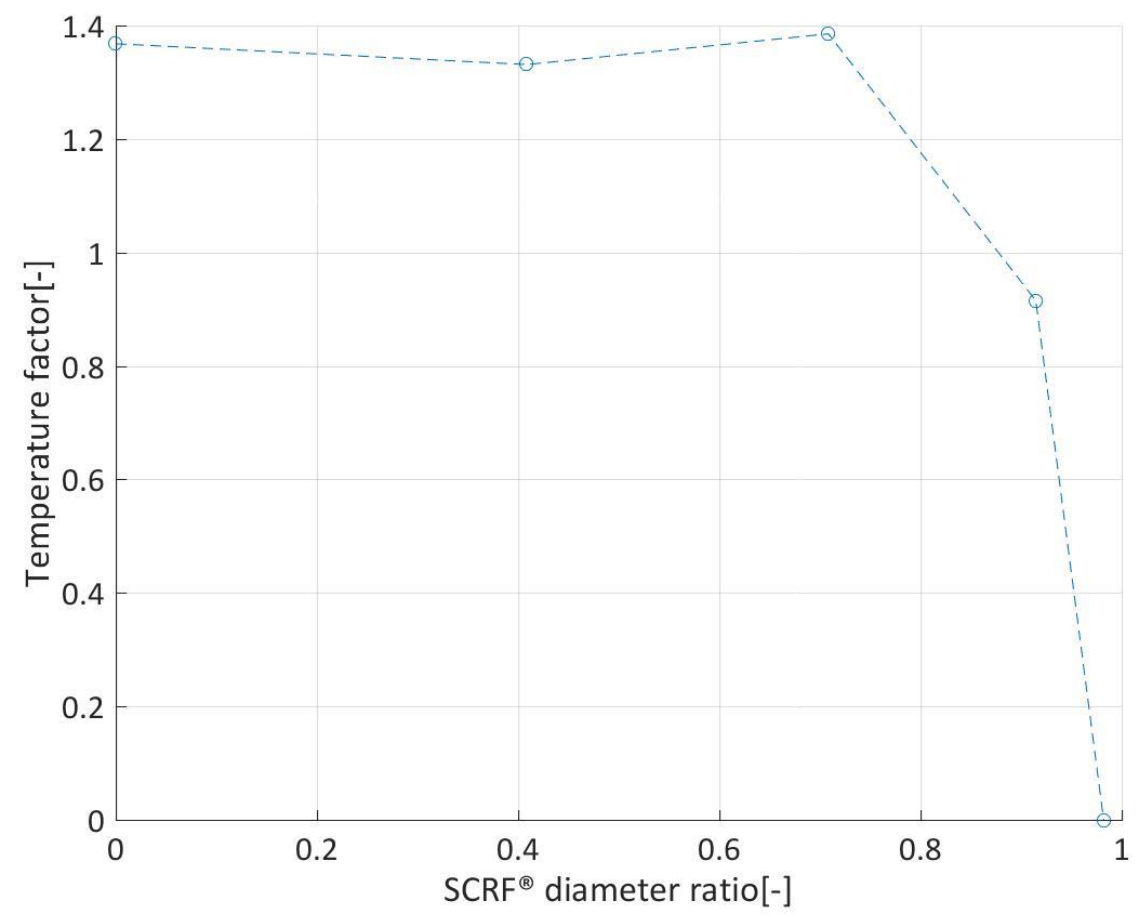

Figure F.32 Temperature distribution at $\mathrm{SCRF}^{\circledR}$ inlet for test point 6 at 13.1 hrs. during $\mathrm{NO}_{\mathrm{x}}$ Reduction Stage (loading at $2 \mathrm{~g} / \mathrm{L}$ ) 


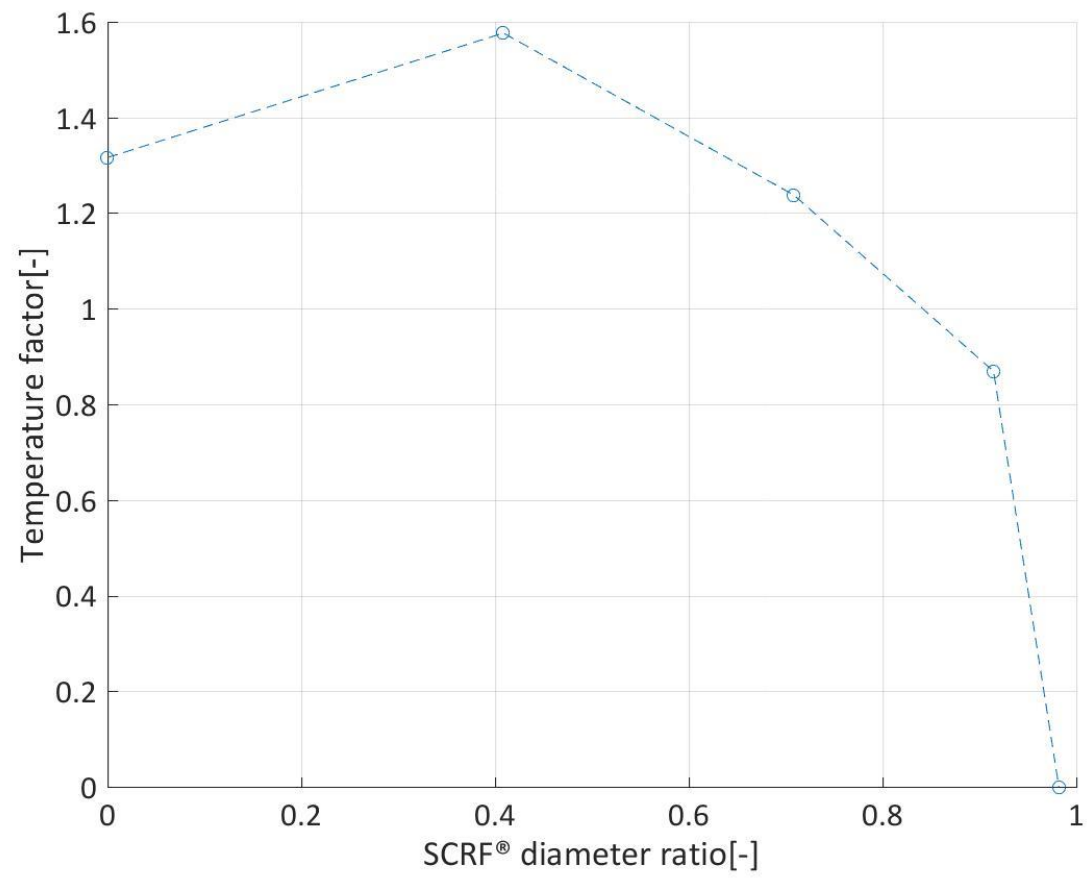

Figure F.33 Temperature distribution at $\mathrm{SCRF}^{\circledR}$ inlet for test point 8 at 12.2 hrs. during $\mathrm{NO}_{\mathrm{x}}$ Reduction Stage (loading at $2 \mathrm{~g} / \mathrm{L}$ )

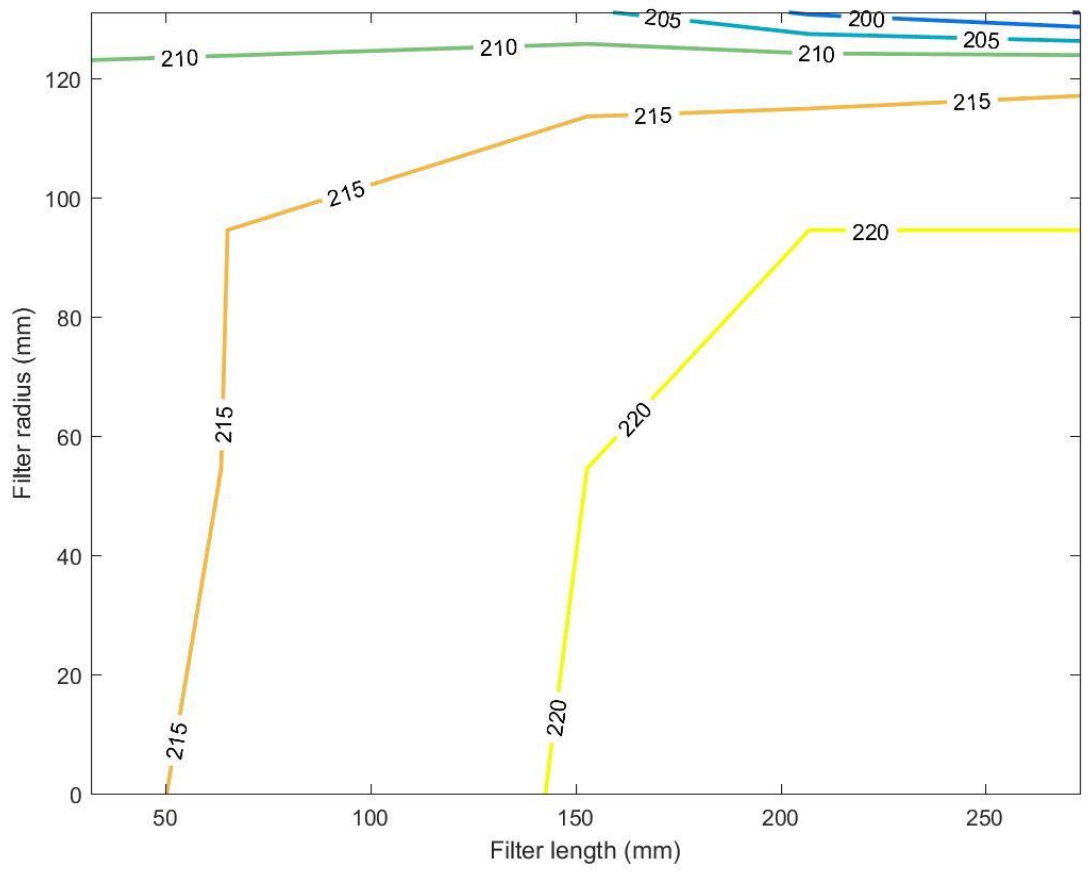

Figure F.34 Temperature distribution in the $\mathrm{SCRF}^{\circledR}$ for test point 1 at 10.6 hrs. during $\mathrm{NO}_{\mathrm{x}}$ Reduction Stage (loading at $2 \mathrm{~g} / \mathrm{L}$ ) 


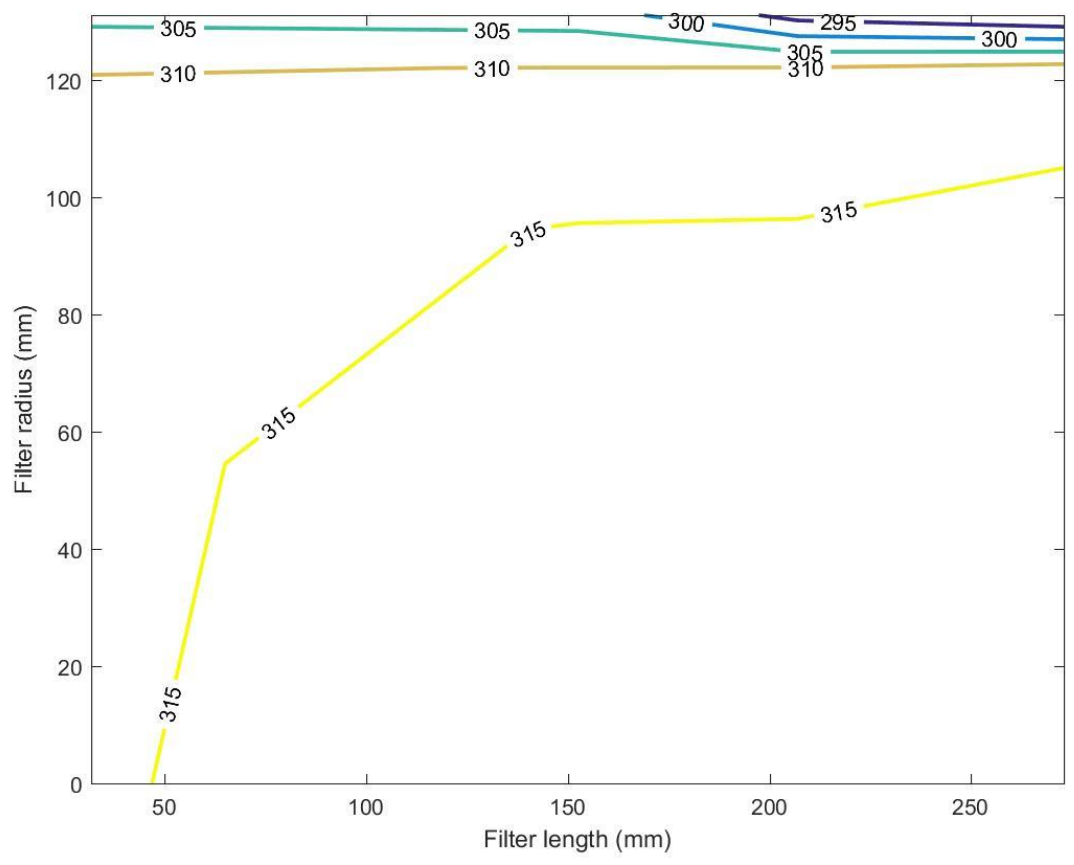

Figure F.35 Temperature distribution in the $\mathrm{SCRF}^{\circledR}$ for test point 3 at $9.4 \mathrm{hrs}$. during $\mathrm{NO}_{\mathrm{x}}$ Reduction Stage (loading at $2 \mathrm{~g} / \mathrm{L}$ ) 
Table F.4 Thermocouple temperatures at $\mathrm{NO}_{\mathrm{x}}$ reduction stage at $2 \mathrm{~g} / \mathrm{L}$

\begin{tabular}{|c|c|c|c|c|c|c|c|c|c|c|c|c|c|c|c|c|c|c|c|c|c|}
\hline \multirow{2}{*}{$\begin{array}{c}\text { NOx } \\
\text { Reduction } \\
\text { Stage - } 2 \\
\text { g/L }\end{array}$} & \multirow{2}{*}{$\begin{array}{l}\text { Time } \\
\text { [hr.] }\end{array}$} & \multicolumn{20}{|c|}{ SCRF $^{\circledR}$ Thermocouple Temperature $\left[{ }^{\circ} \mathrm{C}\right]$} \\
\hline & & S1 & S2 & S3 & $\mathrm{S} 4$ & S5 & S6 & S7 & S8 & S9 & S10 & S11 & S12 & S13 & S14 & $\mathrm{S} 15$ & $\mathrm{~S} 16$ & $\mathrm{~S} 17$ & S18 & S19 & S20 \\
\hline 1 & 10.6 & $214^{1}$ & 213 & 213 & 211 & $205^{1}$ & 221 & 220 & 220 & $213^{1}$ & 206 & 220 & 220 & 220 & 213 & 199 & $221^{1}$ & $221^{1}$ & 220 & 214 & 195 \\
\hline 3 & 9.4 & 314 & 314 & 313 & 310 & 304 & 319 & 317 & 315 & $310^{1}$ & 303 & 318 & 318 & 315 & 310 & 293 & 317 & 318 & 317 & 312 & 290 \\
\hline 6 & 13.1 & 344 & 344 & 345 & $339^{1}$ & $328^{1}$ & 360 & 360 & 360 & $350^{1}$ & 337 & 361 & 361 & 360 & 348 & 325 & 362 & 361 & 361 & 350 & 323 \\
\hline 8 & 12.2 & 441 & $444^{1}$ & 441 & 437 & 429 & 447 & 446 & 445 & $440^{1}$ & 430 & 445 & 446 & 446 & 441 & 418 & 447 & 447 & $448^{1}$ & 442 & 422 \\
\hline
\end{tabular}

${ }^{1}$ The highlighted thermocouple temperatures have been approximated on the basis of the trend of thermocouple temperatures $\stackrel{\infty}{\mapsto} \quad$ in other test points. 


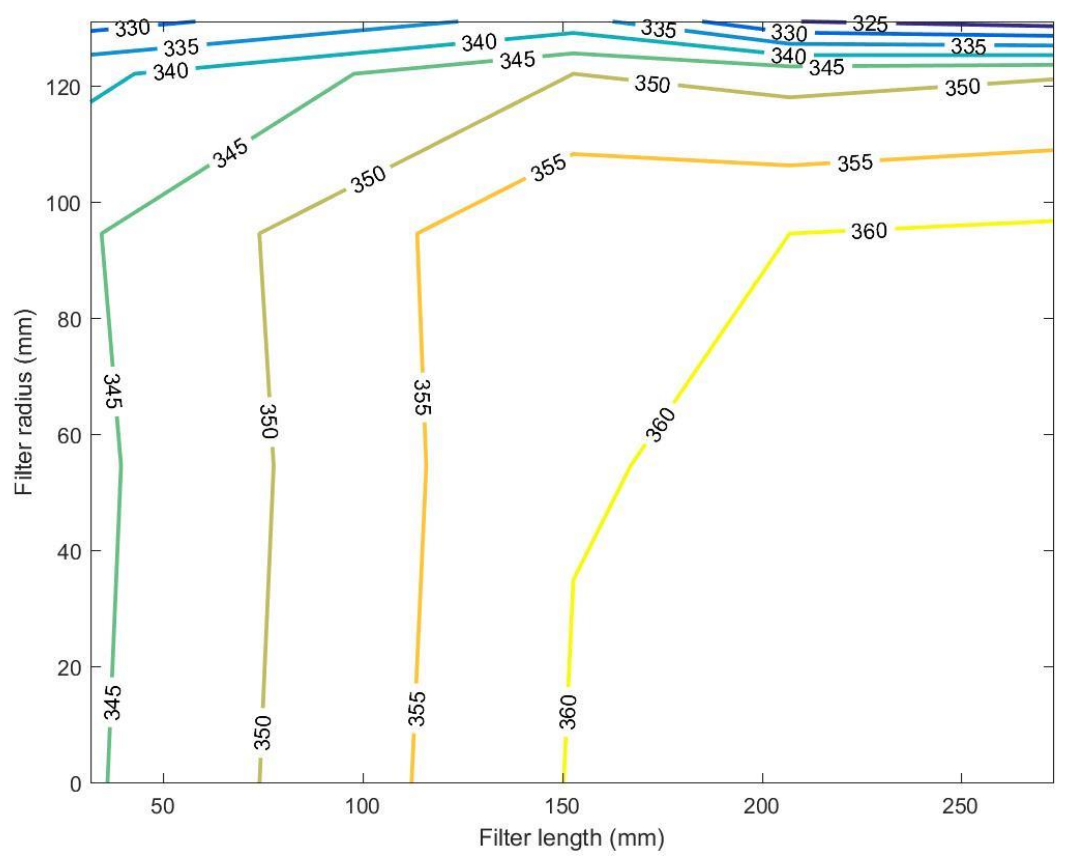

Figure F.36 Temperature distribution in the $\mathrm{SCRF}^{\circledR}$ for test point 6 at $13.1 \mathrm{hrs}$. during $\mathrm{NO}_{\mathrm{x}}$ Reduction Stage (loading at $2 \mathrm{~g} / \mathrm{L}$ )

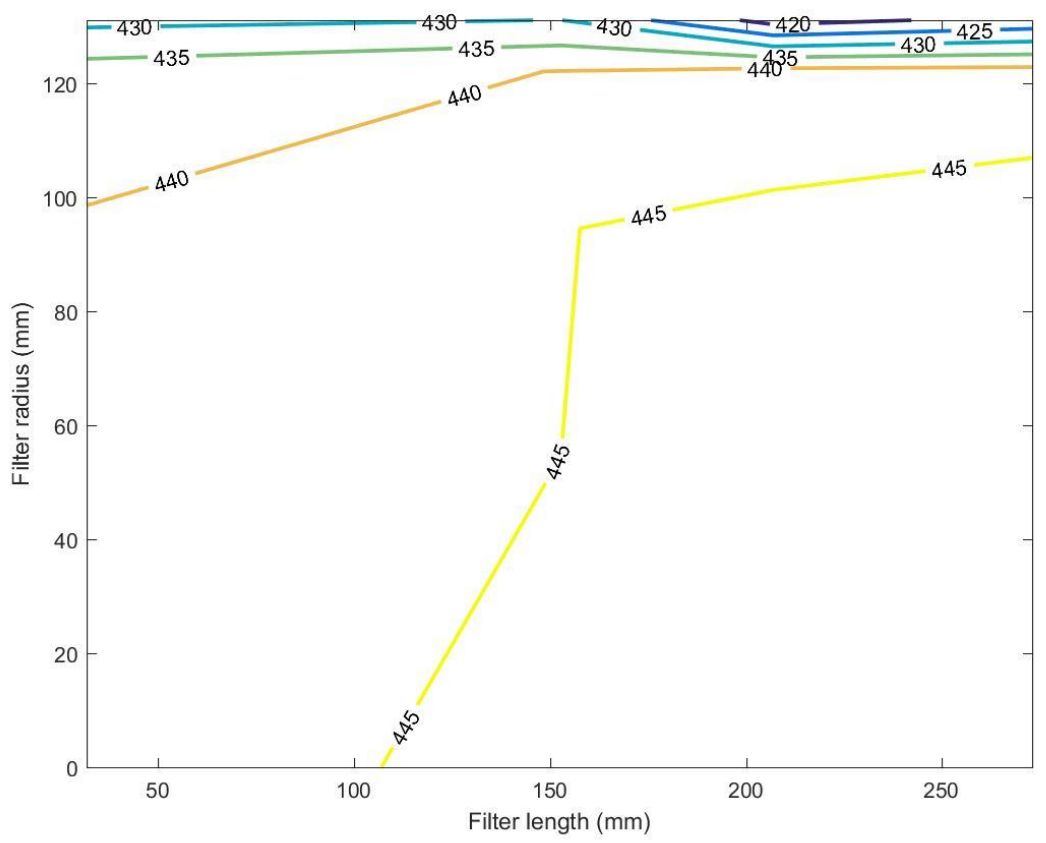

Figure F.37 Temperature distribution in the $\mathrm{SCRF}^{\circledR}$ for test point 8 at 12.2 hrs. during $\mathrm{NO}_{\mathrm{x}}$ Reduction Stage (loading at $2 \mathrm{~g} / \mathrm{L}$ ) 


\section{Loading at $4 \mathrm{~g} / \mathrm{L}$}

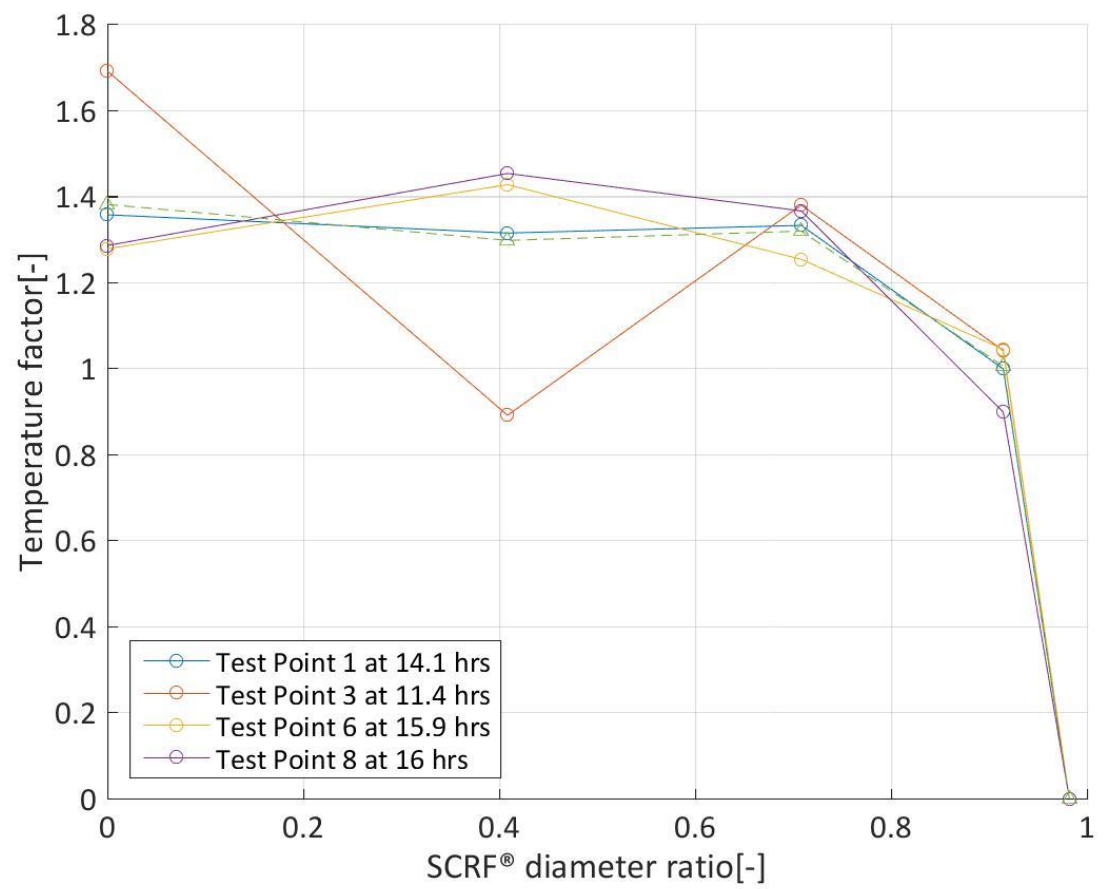

Figure F.38 Temperature boundary layer at $\mathrm{SCRF}^{\circledR}$ inlet for $\mathrm{NO}_{\mathrm{x}}$ Reduction Stage (loading at $4 \mathrm{~g} / \mathrm{L}$ )

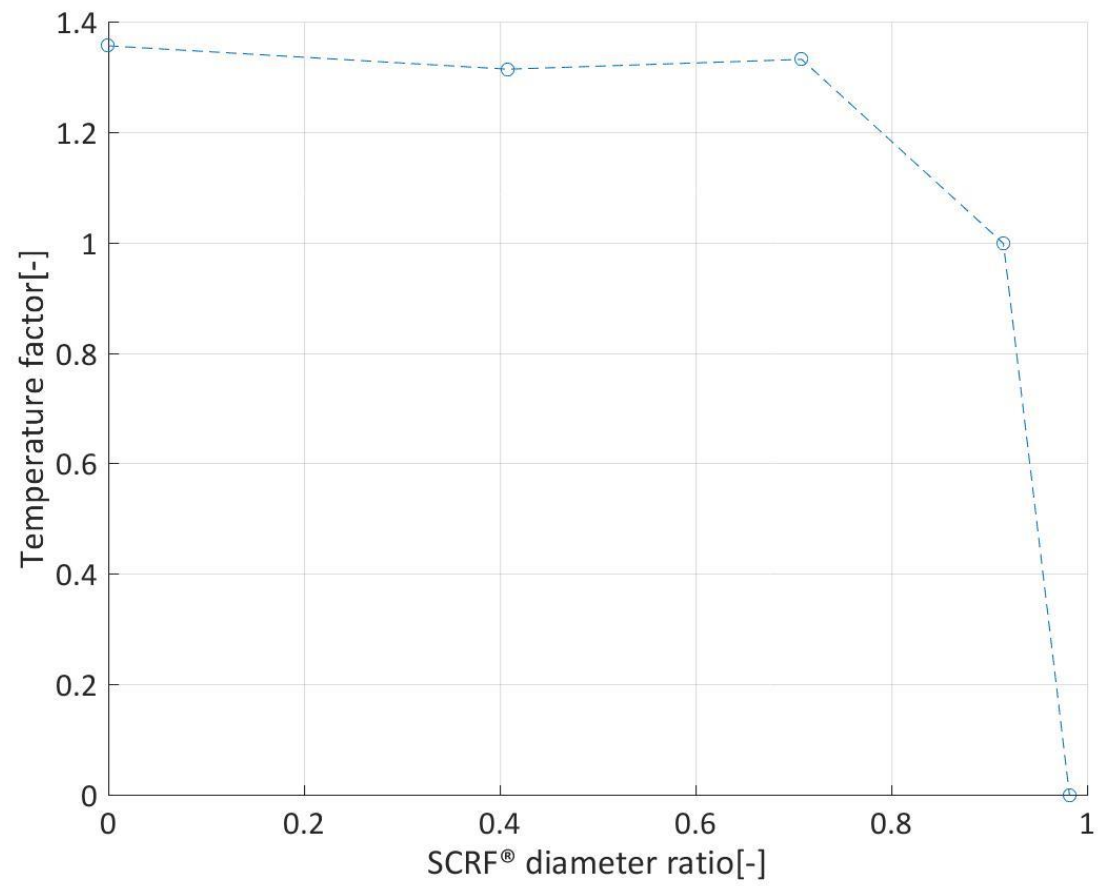

Figure F.39 Temperature distribution at $\mathrm{SCRF}^{\circledast}$ inlet for test point 1 at $14.1 \mathrm{hrs}$. during $\mathrm{NO}_{\mathrm{x}}$ Reduction Stage (loading at $4 \mathrm{~g} / \mathrm{L}$ ) 


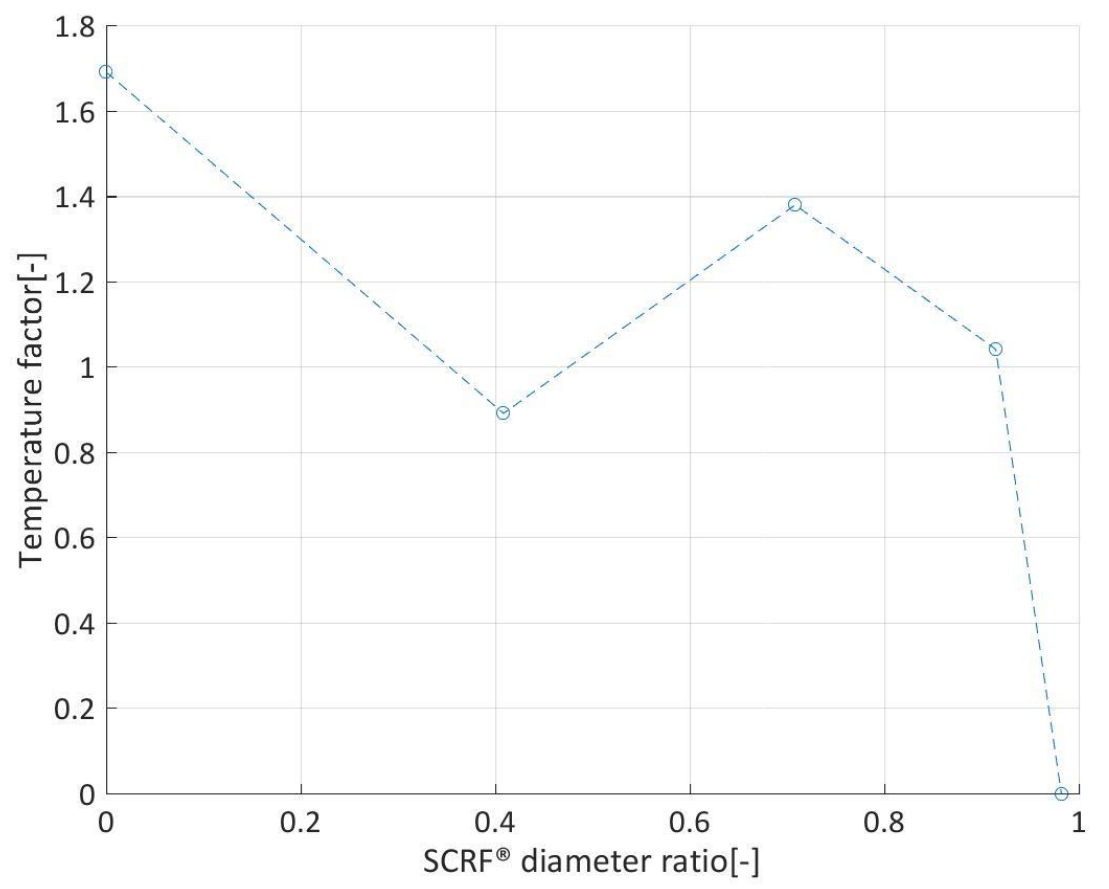

Figure F.40 Temperature distribution at $\mathrm{SCRF}^{\circledR}$ inlet for test point 3 at $11.4 \mathrm{hrs}$. during $\mathrm{NO}_{\mathrm{x}}$ Reduction Stage (loading at $4 \mathrm{~g} / \mathrm{L}$ )

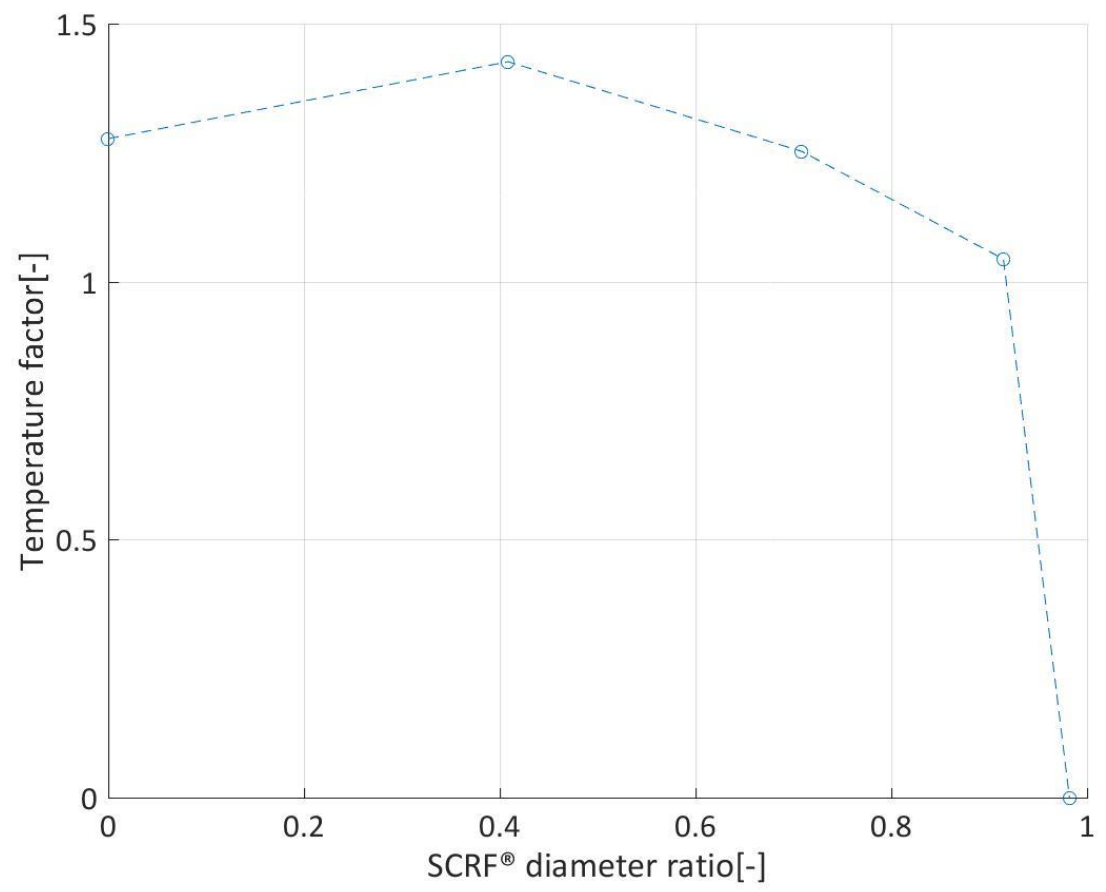

Figure F.41Temperature distribution at $\mathrm{SCRF}^{\circledR}$ inlet for test point 6 at 15.9 hrs. during $\mathrm{NO}_{x}$ Reduction Stage (loading at $4 \mathrm{~g} / \mathrm{L}$ ) 


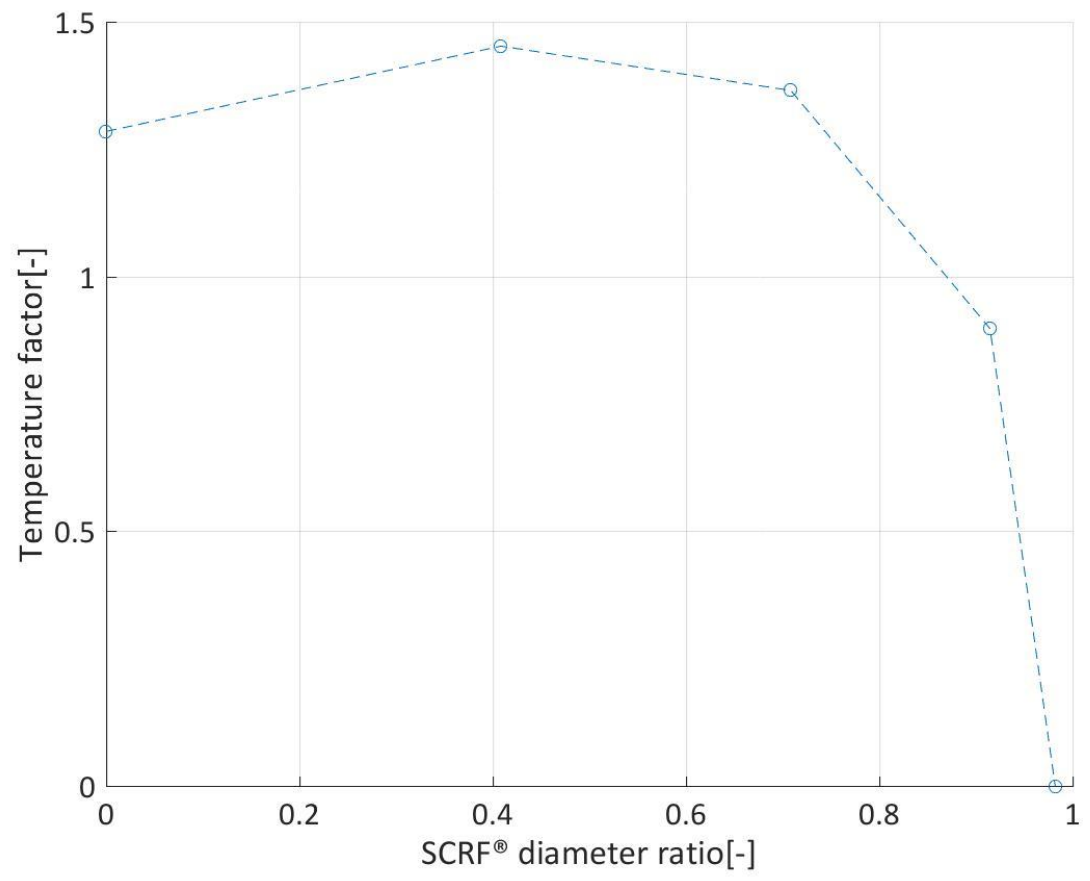

Figure F.42 Temperature distribution at $\mathrm{SCRF}^{\circledR}$ inlet for test point 8 at $16.0 \mathrm{hrs}$. during $\mathrm{NO}_{x}$ Reduction Stage (loading at $4 \mathrm{~g} / \mathrm{L}$ )

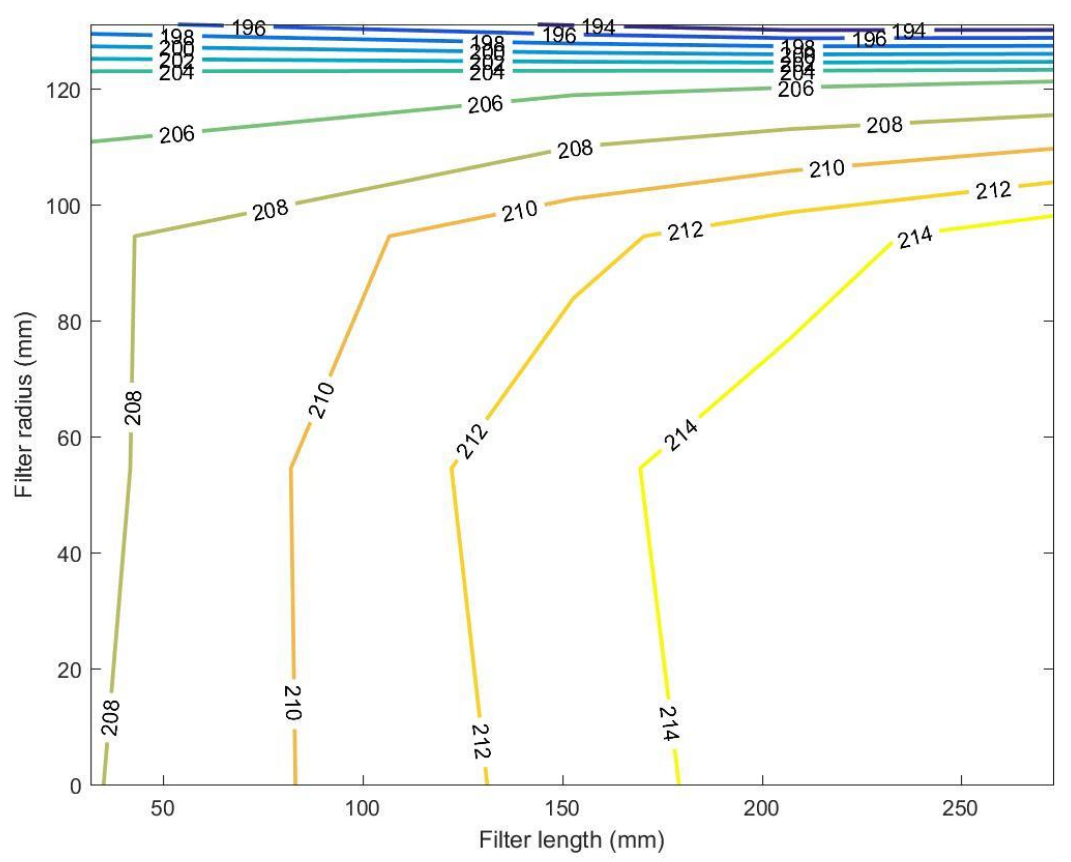

Figure F.43 Temperature distribution in the $\mathrm{SCRF}^{\circledR}$ for test point 1 at 14.1 hrs. during $\mathrm{NO}_{\mathrm{x}}$ Reduction Stage (loading at $4 \mathrm{~g} / \mathrm{L}$ ) 


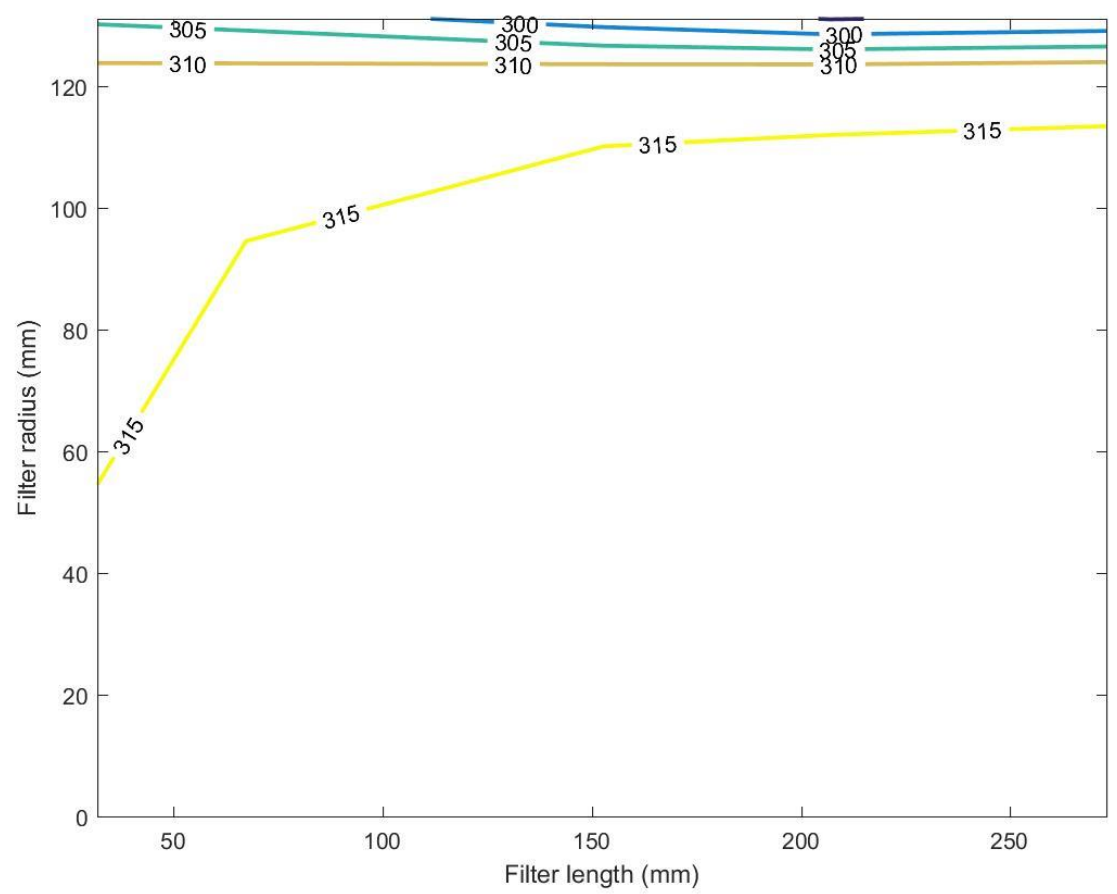

Figure F.44 Temperature distribution in the $\mathrm{SCRF}^{\circledR}$ for test point 3 at 11.4 hrs. during $\mathrm{NO}_{\mathrm{x}}$ Reduction Stage (loading at $4 \mathrm{~g} / \mathrm{L}$ )

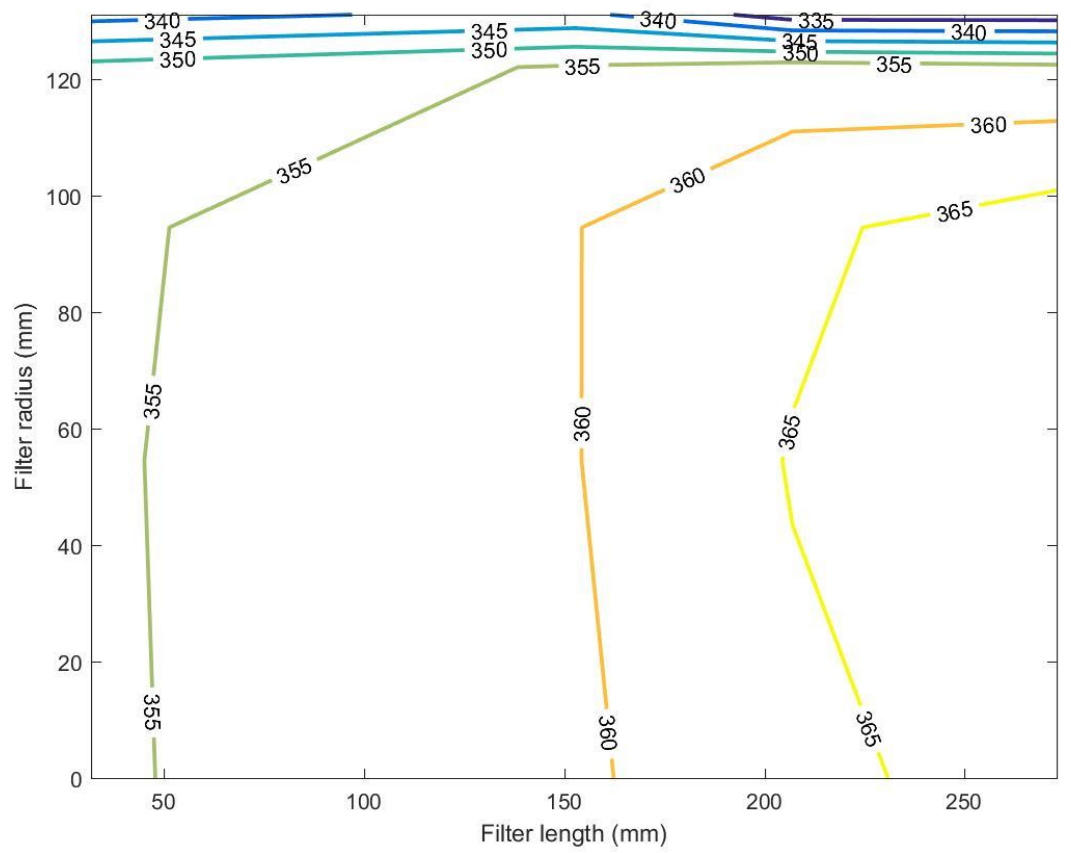

Figure F.45 Temperature distribution in the $\mathrm{SCRF}^{\circledast}$ for test point 6 at 15.9 hrs. during $\mathrm{NO}_{\mathrm{x}}$ Reduction Stage (loading at $4 \mathrm{~g} / \mathrm{L}$ ) 
Table F.5 Thermocouple temperatures at $\mathrm{NO}_{\mathrm{x}}$ reduction stage at $4 \mathrm{~g} / \mathrm{L}$

\begin{tabular}{|c|c|c|c|c|c|c|c|c|c|c|c|c|c|c|c|c|c|c|c|c|c|}
\hline \multirow{2}{*}{$\begin{array}{c}\text { NOx } \\
\text { Reduction } \\
\text { Stage - } 4 \\
\text { g/L } \\
\end{array}$} & \multirow{2}{*}{$\begin{array}{l}\text { Time } \\
\text { [hr.] }\end{array}$} & \multicolumn{20}{|c|}{ SCRF $^{\circledR}$ Thermocouple Temperature $\left[{ }^{\circ} \mathrm{C}\right]$} \\
\hline & & S1 & S2 & S3 & S4 & S5 & S6 & S7 & S8 & S9 & S10 & S11 & S12 & $\mathrm{S} 13$ & S14 & S15 & S16 & S17 & S18 & S19 & S20 \\
\hline 1 & 14.1 & $208^{1}$ & 208 & 208 & 205 & 196 & 213 & 214 & $211^{1}$ & $205^{1}$ & $194^{1}$ & 215 & 215 & $213^{1}$ & $205^{1}$ & 193 & 216 & 215 & 215 & 206 & 193 \\
\hline 3 & 11.4 & 316 & 310 & 314 & 311 & 304 & 320 & 319 & 318 & $313^{1}$ & $298^{1}$ & 319 & 325 & 318 & 313 & 295 & $320^{1}$ & $318^{1}$ & 318 & $314^{1}$ & 296 \\
\hline 6 & 15.9 & 354 & 356 & 354 & 351 & 338 & 359 & 360 & 360 & $355^{1}$ & 341 & 364 & 365 & 364 & 357 & 333 & 367 & 369 & 368 & 356 & 333 \\
\hline 8 & 16.0 & 447 & 448 & 447 & 444 & 439 & 454 & 453 & 453 & $447^{1}$ & $430^{1}$ & $454^{1}$ & 454 & 449 & 448 & 426 & 454 & 455 & 454 & 447 & 426 \\
\hline
\end{tabular}

${ }^{1}$ The highlighted thermocouple temperatures have been approximated on the basis of the trend of thermocouple temperatures in other test points. 


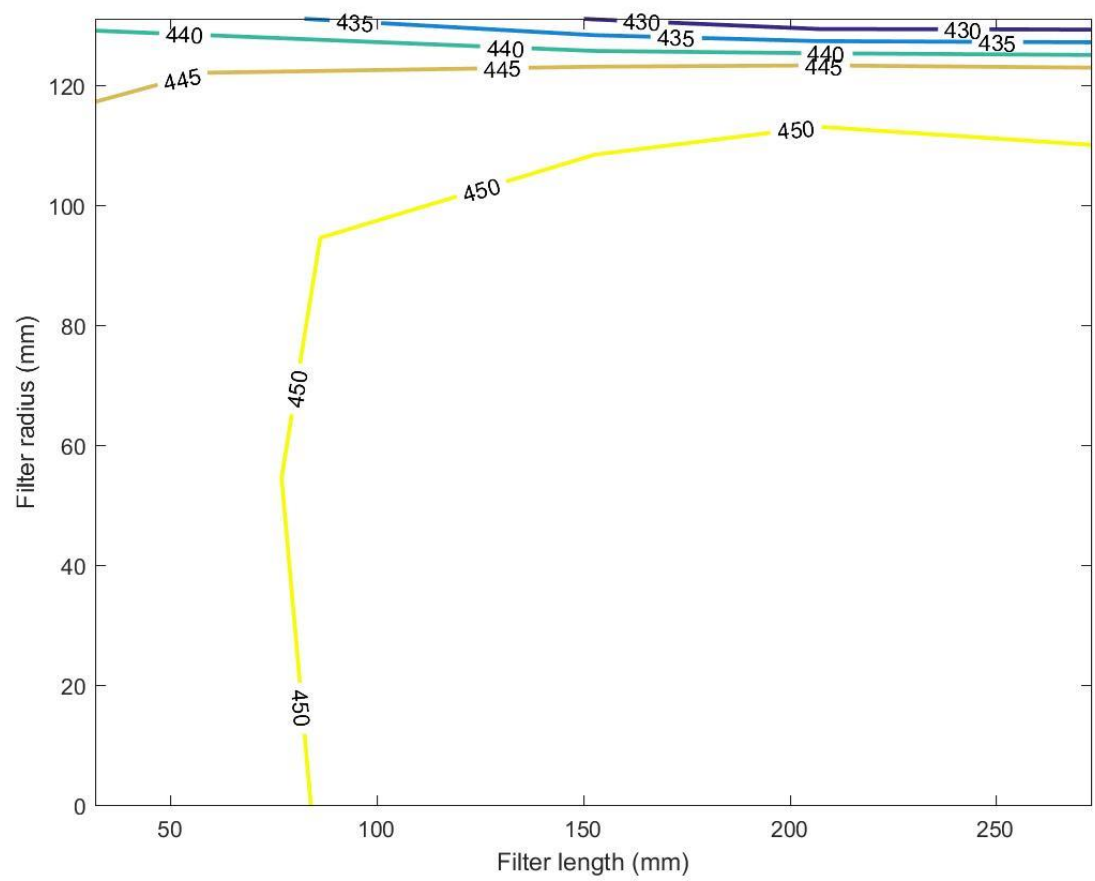

Figure F.46 Temperature distribution in the $\mathrm{SCRF}^{\circledR}$ for test point 8 at 16.0 hrs. during $\mathrm{NO}_{\mathrm{x}}$ Reduction Stage (loading at $4 \mathrm{~g} / \mathrm{L}$ ) 


\section{Appendix G. Permission to Use Copyrighted Material

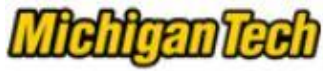 \\ Saksham Gupta <sakshamg@mtu.edu>}

\section{Permission to use figure and tables from your MS Thesis}

Krishnan Raghavan <kgraghav@mtu.edu>

To: Saksham Gupta <sakshamg@mtu.edu>

Tue, May 3, 2016 at 11:23 PM

Hi Saksham,

Please go ahead and use any required figures and/or tables from my thesis. Best wishes for your report.

Regards,

Krishnan Raghavan

On Tue, May 3, 2016 at 11:12 PM, Saksham Gupta <sakshamg@mtu.edu> wrote:

Hi Krishnan,

I would like to request for your permission to adapt and use Figure 3.2, Table 3.3, Table 3.11, and Table 3.12

from your Master's Thesis in my MS Report titled "An Experimental Investigation into the Effect of Particulate

Matter on NOx Reduction in a SCR Catalyst on a DPF" to detail about experimental setup, fuel properties, and test cell instruments.

Kindly respond with a text in your reply.

Thanks,

\section{Saksham Gupta}

Graduate Student

Mechanical Engineering-Engineering Mechanics

Michigan Technological University

MI-49931

Mobile: 906.370 .7029

Email: sakshamg@mtu.edu 